\begin{tabular}{c} 
A Dissertation \\
Presented to \\
the Faculty of the Graduate School \\
at the University of Missouri \\
\hline
\end{tabular}

In Partial Fulfillment

of the Requirements for the Degree

Doctor of Philosophy

By

JESSICA D. FIELDS

Dr. Lisa Sattenspiel, Dissertation Supervisor

MAY 2020 
The undersigned, appointed by the dean of the Graduate School, have examined the dissertation entitled

\section{BIRTH ORDER AND GENDER: DIFFERENTIAL PARENTAL INVESTMENT IN MEDIEVAL ENGLAND AND FRANCE IN THE ELEVENTH, TWELFTH, AND THIRTEENTH CENTURIES}

presented by Jessica D. Fields,

a candidate for the degree of Doctor of Philosophy,

And hereby certify that, in their opinion, it is worthy of acceptance.

Professor Lisa Sattenspiel

Professor Todd VanPool

Professor Robert Walker

Professor Lois Huneycutt

Professor Mary Shenk 


\section{ACKNOWLEDGEMENTS}

When undertaking a project such as this, you do not realize the impact that it will have not only on your own life, but on the lives of those around you. This project has been a labor of love and hate and it would not have been possible without the support of my family and colleagues. First to Dr. Mary Shenk, my advisor who took me under her wing, the wide-eyed woman from Indiana who really was not aware of what she had just gotten herself into. She allowed me to work with her for the last ten years and dedicated countless hours to re-teaching me statistics, reviewing too many dissertation revisions to count, and maintaining her patience as life happened in my little slice of Indiana. I can never fully express my gratitude.

Thank you to my committee members, Dr. Lisa Sattenspiel, Dr. Todd VanPool, Dr. Rob Walker, and Dr. Lois Huneycutt who have been incredibly patient with me for the last couple of years.

I would also like to thank my colleagues especially Dr. Christopher Olsen (Indiana State University) who as the chair of my Master's Committee pushed me to pursue my dream of obtaining my doctorate. Dr. Steve Stofferahn (Indiana State University) and Dr. Allen Shotwell (Ivy Tech) my department chairs who were willing to work around my school schedule so that I could go to school and still teach.

Last, but certainly not least, my family. I never would have made it through this experience without all of you. Dad, you pushed me when the tank was empty with 'you can do this sis God has not brought you this far to let you down now.' Grandma, thank you for your support on this project, but also on all of the other projects that got me to 
this point. We have been through some tough times, but we stuck it out. You will never know how much I appreciated your love and support. To Aunt Debbie, for sitting and drinking hot tea with me trying to keep me awake while I was inputting data into what seemed like a never-ending database. To Hunter, Gabe, and Katie, thank you for keeping me on my toes. Team History! Laura, Katie, and Leo, thank you for the much needed Brown County trips, sometimes you just need to get away to find your center. 
TABLE OF CONTENTS

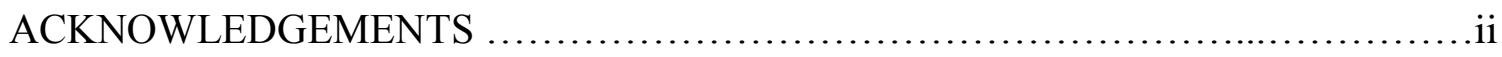

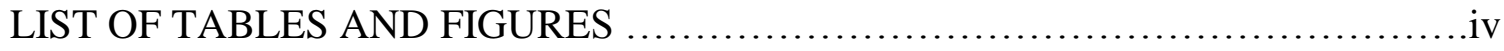

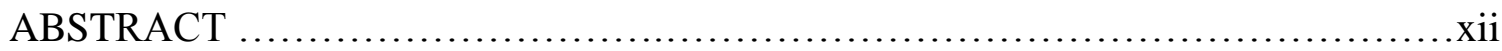

Chapters

1. INTRODUCTION

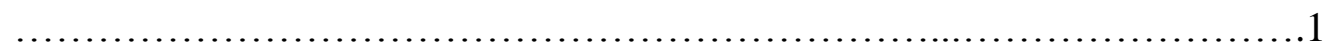

2. Child Survival, Parental Investment, and Marriage............................

Introduction

Trade-off between current and future reproduction

Trade-off between quality and quantity of offspring

Trade-off between mating and parenting effort

Male Provisioning Hypothesis

Parental Investment

Maternal Investment

Paternal Investment

Benefits to children

Paternity certainty

Mating opportunities

Alloparenting

Wet nursing as alloparental care

Child Survival

Reduced Parental Investment

Biases in Parental Investment due to Sex and Birth Order

Marriage in Evolutionary Perspective

Kinship

Marriage

Incest Avoidance

Marriage and Status

Consanguineous Marriage

Extensive and Intensive Kinship Systems

3. Chapter Three: History of medieval Europe, England, and France.............76

Historical background of medieval Europe

Historical background of medieval England

Historical background of medieval France

Family relations in medieval Europe

Marriage in medieval Europe

Church influence on marriage

Church influence on consanguineal marriage 
Marriage in England

Marriage in France

Inheritance patterns in Europe

4. Chapter Four: History of Focal Families............................. 110

L'Aigle family

Bigod family

Brus family

House of Godwin

Marshal family

House of Welf

Montgomerie family

Beaumont family

de Vere family

Avesnes family

Earls of Northumbria

Flanders family

House of Reginar

Giffard family

de Clare family

5. Chapter Five: Methods

Introduction

Study Population

Sources used for data collection

Data Collection

Variables

Genealogy charts

6. Chapter Six: Child Survival........................................... 184

Introduction

Birth order and Gender

Hypothesis 1a

Hypothesis $2 \mathrm{a}$

Results

Hypothesis $1 \mathrm{~b}$

Hypothesis $2 b$

Results

Hypothesis 3a

Hypothesis $3 b$

Results 
7. Chapter Seven: Parental Investment

Introduction

$$
\begin{aligned}
& \text { Hypothesis 4a } \\
& \text { Results } \\
& \text { Hypothesis } 4 \mathrm{~b} \\
& \text { Results } \\
& \text { Hypothesis 4c } \\
& \text { Results } \\
& \text { Hypothesis 5a } \\
& \text { Results } \\
& \text { Hypothesis 5b } \\
& \text { Results } \\
& \text { Hypothesis } 6 \\
& \text { Results }
\end{aligned}
$$

8. Chapter Eight: Marriage.

Introduction

Hypothesis 7

Results

Hypothesis 8

Results

9. Chapter Nine: Reproductive Success.

Introduction

Hypothesis 9a

Hypothesis 9b

Results

10. Chapter Ten: Discussion and Conclusion

Child survival

Parental investment

Marriage

Reproductive success

Conclusions

1. Family Group Sheet

REFERENCES.

VITA. 


\section{LIST OF TABLES AND FIGURES}

Tables

Page

1. L'Aigle family demographics....................................... 112

2. Bigod family demographics........................................... 114

3. Brus family demographics........................................ 120

4. Godwin family demographics...................................... 124

5. Marshal family demographics....................................... 128

6. Welf family demographics............................................ 130

7. de Montgomerie family demographics.................................. 133

8. Beaumont family demographics...................................... 136

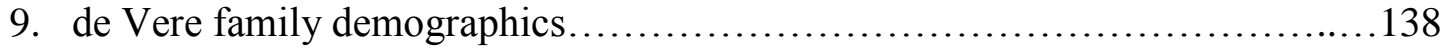

10. Avesnes family demographics..................................... 143

11. Northumbria family demographics................................... 148

12. Flanders family demographics...................................... 151

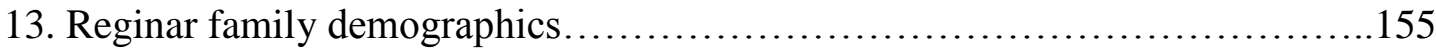

14. Giffard family demographics...................................... 157

15. de Clare family demographics...................................... 160

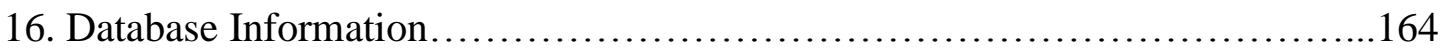

17. Methods of title transfer........................................... 171

18. Title Classification.................................................. 171

19. Church related titles................................................ 173

20. Summary statistics for categorical variables............................ 177

21. Summary statistics for continuous variables........................... 182

22. Genealogical chart data........................................... 183

23. Results of a Binary Logistic Regression using independent variables first and second born sons and daughters and dependent variable child survival to age 5 
24. Results of a Binary Logistic Regression using variables independent variables first and second born sons and daughters and dependent variable child survive to age 15

25. Descriptive Statistics showing results for effect of birth order and gender on likelihood of surviving to age 5 ( $0=$ did not survive, $1=$ survived)

26. Results of binary logistic regression estimates using independent variables sex and birth order and dependent variable survive to age 5 .

27. Descriptive Statistics showing results for effect of birth order and gender on likelihood of surviving to age 15 ( $0=$ did not survive, $1=$ survived)

28. Results of bivariate logistic regression estimates using independent variables sex and birth order and dependent variable survival to age 15

29. Generalized Linear Model showing the results for independent variables gender and birth order and outcome variable number of titles.

30. Multinomial logistic regression showing the results for effect of birth order and highest title for sons and daughters

31. Binary Logistic Regression Model showing the results for independent variable birth order for sons and the dependent variable enter Church................203

32. Binary Logistic Regression Model showing the results for independent variable birth order for sons and dependent variable attain high rank in the Church....204

33. Binary Logistic Regression Model showing the results for independent variables birth order for daughters and the dependent variable enter Church............205

34. Binary Logistic Regression Model showing the results for independent variables birth order for daughters and the dependent variable obtain Church titles......207

35. Ordinal Regression Model showing the results for independent birth order for sons and outcome variable estate size.................................208

36. Multinomial Logistic Regression showing results for effect of birth order and gender on likelihood of marrying consanguineous kin versus affinal kin.......211

37. Multinomial Logistic Regression showing results for effect of offspring with birth order of 3 and above and gender on likelihood of marrying consanguineous kin versus affinal kin 
38. Results of a Binary Logistic Regression using independent variable birth order for daughters and dependent variable spouse less than 5 years older............215

39. Poison loglinear generalized linear model showing the effects of independent variables first and second born sons and daughters on the outcome variable number of children.

40. Poison loglinear generalized linear model showing the effects of independent variable sons and daughters with a birth order of 3 and above on the outcome variable number of children.

41. Poison loglinear generalized linear model showing the effects of independent variable first and second born sons and daughters on the outcome variable number of grandchildren.

42. Poison loglinear generalized linear model showing the effects of independent variable sons and daughters with a birth order of 3 and up on the outcome variable number of grandchildren.

43. Poison loglinear generalized linear model showing the effects of independent variable first and second born sons and daughters on the outcome variable number of great grandchildren.........................................223

44. Poison loglinear generalized linear model showing the effects of independent variables sons and daughters with a birth order of 3 and up on the outcome variable number of great-grandchildren.

45. Poison loglinear generalized linear model showing the effects of independent variables first and second born sons and daughters on the outcome variable number of great-great-grandchildren.................................225

46. Poison loglinear generalized linear model showing the effects of independent variables sons and daughters with a birth order of 3 and up and the outcome variable number of great-great-grandchildren 
Figures

1. Hapsburg Family Tree................................................ 73

2. Map of medieval Europe.............................................. 76

3. Map of England under King Alfred ........................................ 79

4. Map of medieval England ......................................... 80

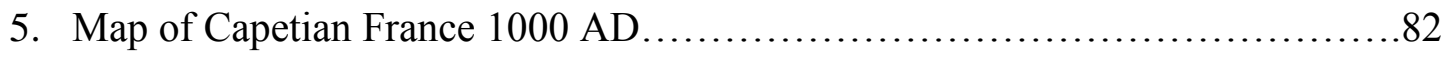

6. Degrees of Consanguinity Table......................................... 94

7. Location of the L'Aigle lands in Normandy................................... 111

8. Bigod lands in eastern England....................................... 113

9. Bigod Family Genealogical Chart..................................... 115

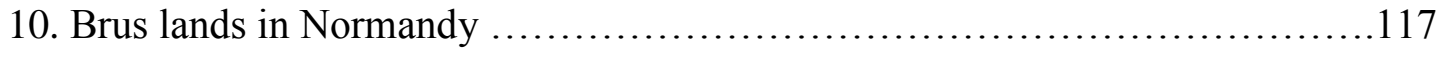

11. Brus lands in England ........................................... 118

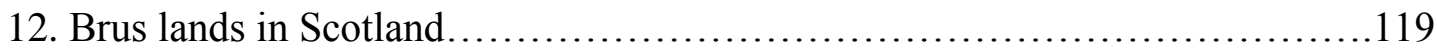

13. Brus family Genealogical Chart ..................................... 121

14. Godwin lands in England .......................................... 123

15. Marshal lands in England and Wales ................................. 125

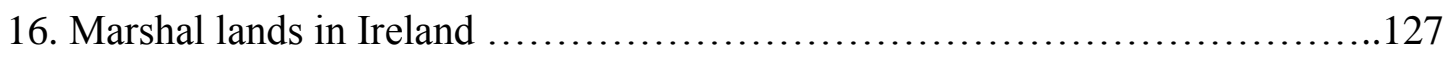

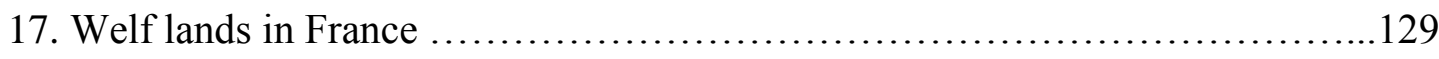

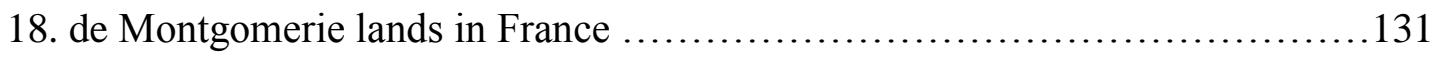

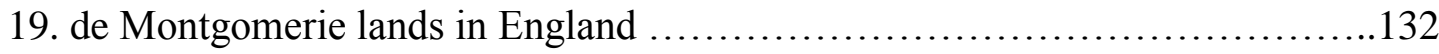

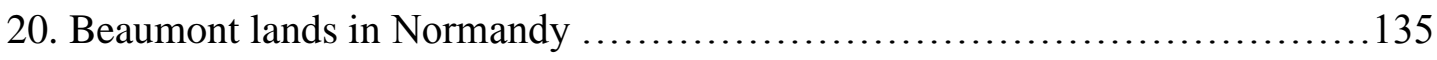

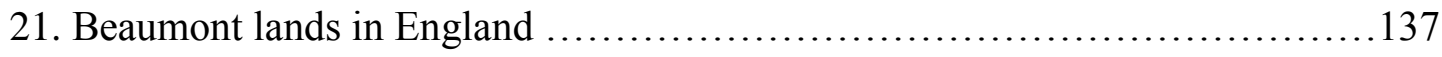

22. de Vere lands in England........................................... 139 


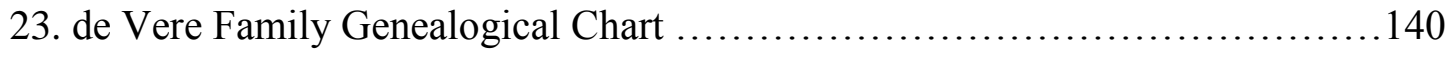

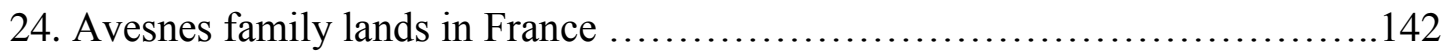

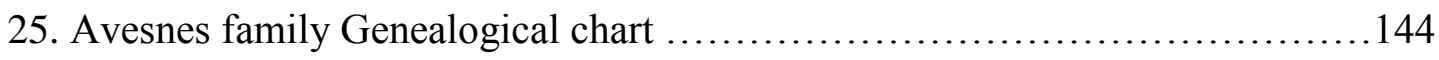

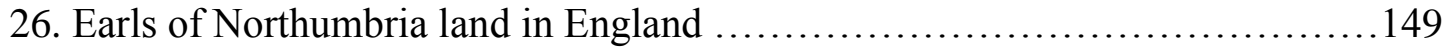

27. Flanders family land in England .................................... 152

28. Reginar lands .................................................. 154

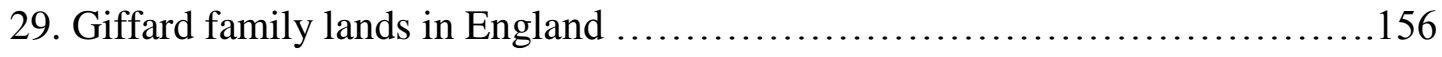

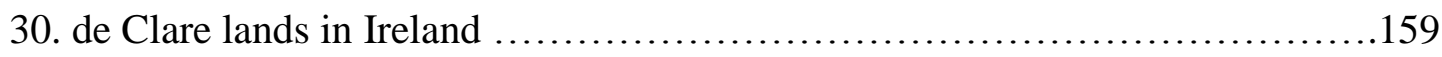

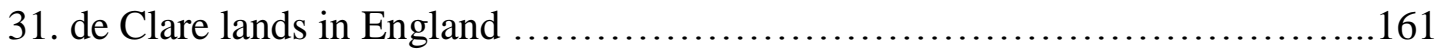




\begin{abstract}
This dissertation addresses the question: will parents invest differently in their children based on gender and birth order? Using parental investment theory and four major sets of outcome variables--child survival, parental investment (through wealth, land, and titles), marriage, and reproductive success - this question will be examined in an historic population, medieval England and France in the eleventh, twelfth, and thirteenth centuries. The results presented in this dissertation shows that parents were willing to invest in their offspring differentially with a preference for sons over daughters and older children over younger children. Historic populations provide a microcosm in which to study human behavior. The findings in this dissertation have implications for both evolutionary ecology and evolutionary demography.
\end{abstract}




\section{Chapter One: Introduction}

In some societies, parents are expected to invest in their offspring equally regardless of birth order or gender. However, evolutionary theory predicts that human behavior, including parental behavior will vary as the result of local socioecological circumstance (Cronk 1991; Buss and Schmitt 1993; Borgerhoff-Mulder and Schacht 2012). Human behavioral ecology is a collection of evolutionary theories including but not limited to life history, parental investment, inclusive fitness, kin selection, and parentoffspring conflict. Each of these theories are interested in the interaction among kin, including parents and children, and the trade-offs faced by individuals between current and future investment in offspring as well the quantity and quality of offspring. Investing in current offspring decreases the level of investment available for future offspring. However, differential parental investment, based on gender or birth order, may increase the quality of children and/or the parent's reproductive success (Boone 1986, 1988; Hrdy 1992). By investing differentially in children by sex and birth order, parents may be able to increase the overall quality of their progeny. Increased quality of offspring can translate into a higher potential of them providing their own offspring (grandchildren) therefore increasing the overall reproductive success of their parents.

Understanding the demographic variation within populations is an aspect of evolutionary demography. By examining the fertility and mortality rates of a population, demographic patterns can be determined. In historic populations, this takes the form of historical demography by focusing on changes in population rates (fertility and mortality) as well as changes to socioeconomic status and its impact on fertility and mortality. 
People in many societies will openly strategize about the number of children they produce, the sex of each child, and how to use those children to increase their power and status (Hrdy 1992; Boone 1986, 1988). The amount and type of investment parents provide to their offspring varies cross-culturally. While mothers are the primary providers of investment, especially in young children, fathers also provide varying amounts of investment in their young. Parental investment has been examined in numerous populations with varying levels of complexity and across varying types of socioecology (Boone 1986, 1988, Cronk 1988, Hrdy 1992; Hewlett 2014; Low 1991; Mace 1996; Mace and Sear 1998). Among the Aka, a traditional hunter-gatherer society living in the southwestern part of the Central African Republic, Hewlett (1988 and Hewlett et al. 2014) found that low status fathers invested more direct parental care in their children than did high status men. Specifically, low status men held, coddled, and fed their children nearly $80 \%$ of the time compared to high status fathers who only interacted with their children approximately $10 \%$ of the time. In the Ache, a hunter-gatherer society living in eastern Paraguay, in contrast, little direct paternal investment occurs.

Such was the case with members of the aristocracy in medieval England and France. By choosing which children to invest in and to what degree, members of this cross-channel aristocracy strategized about how many children to produce and how best to use them. While their evolutionary motivations may not have been conscious, their strategies and behavior reflect evolutionary logic. This is consistent with what a number of studies on parental investment among the European elite have found (Boone 1986, 1988; Hrdy 1992; Hrdy and Judge 1993). 
In addition to the amount of investment parents are willing to provide to their offspring, it is also possible for parents to choose which offspring to invest in. Trivers and Willard (1973) argued that parents would bias investment toward those offspring that have the greatest potential for survival and reproduction. Depending on the condition of the parents, this could vary based on sex of the child. Selection would favor parents in good condition who invested more heavily in sons while those parents in poor condition would invest more in daughters (Trivers 1972; Cronk 1991). Likewise, in an environment where resources are scarce, parental investment would likely be concentrated in current offspring, while in an environment where resources are abundant, parental investment may be divided between current offspring and the production of additional offspring. Both life history theory and parental investment theory focus on tradeoffs between current investment in offspring and investment in future offspring as well as the tradeoff between quality and quantity of offspring. By investing in current offspring, the level of investment available for future offspring decreases. This is turn may decrease the reproductive success of the parent. To counteract this, parental investment may decrease per offspring in order to maximize the number of offspring (Kaplan \& Gangestad 2005). Differential parental investment, based on gender or birth order, may increase the parent's reproductive success (Boone 1986, 1988; Hrdy 1992).

One form of parental investment can be the arrangement of advantageous marriages. In a closed population with strict inheritance patterns the ideal marriage partner may in fact be someone who is closely related to the potential spouse. In most societies there are restrictions on marriages between close kin. However, when there are large amounts of heritable resources, such as large estates, wealth, and titles, these 
restrictions may be lessened. Medieval Europe was no exception with the church attempting to prohibit marriages within the fourth degree of consanguinity, i.e. marriages between parents and children, siblings, uncle and niece, or first cousin. This prohibition also extended to affinal kin with marriages forbidden between most in-laws, and sometimes even fictive kin, such as godparent-godchild relationships. Despite these restrictions, both types of marriages occurred on a semi-regular basis throughout the eleventh, twelfth, and thirteenth centuries as families sought to retain their wealth and power by marrying into other wealthy, closely related families.

This dissertation will examine child survival, parental investment, and consanguineous marriages within an historic population in England and France in the eleventh, twelfth, and thirteenth centuries. Data were collected on fifteen aristocratic families: 5 English and 10 French. All of the families in the sample population were products of intermarriage between and among members of the Anglo-Saxon, Scandinavian, northern French and German aristocracies. Using the evolutionary biological theories of life history and parental investment, I will examine a series of hypotheses that parents will invest in their offspring differentially based on the child's sex and birth order. Child survival, sex, birth order, marriage arrangements, wedding transactions, and the transfer of titles are used as indicators of the level of parental investment. Differing levels of parental investment will impact child survival as well as their wealth, marriage prospects, and ultimately their reproductive success.

The tenth century was fraught with uncertainty, largely as a result of the continued Norse invasions that lasted throughout the century in England and the decline of the Carolingian Empire and the resulting power vacuum in France. As the century 
drew to a close, political and economic changes began to occur that resulted in the unification of large portions of England and France under the control of a few individuals. The eleventh, twelfth, and thirteenth centuries saw a relatively stable and similar society develop in England and France which allows for the study of the aristocracies of both countries as part of one population. The fourteenth century saw the arrival of the Bubonic Plague which killed nearly a third of the population and resulted in significant social, political, and economic changes to European society. My analysis thus begins in the eleventh century and ends in the thirteenth century to ensure appropriate comparability across time.

The specific families in the study were chosen because their progenitors were largely members of the Norman aristocracy and took part in the Norman invasion of England in 1066. As a result, these men were rewarded by the new Norman English King William I with extensive tracts of land and in some cases, marriage to the AngloSaxon/Anglo-Danish heiresses to those lands. The reward of these lands and positions established the Norman families as some of the most powerful families in England and in many cases also secured and strengthened their positions in Norman society. This dominance translated over several generations with the careful and deliberate transmission of land, wealth, and titles across multiple generations.

Members of the English and French aristocracies of medieval Europe provide a microcosm in which to study parental investment and child survival. Society was governed by specific patterns that dictated interaction between parents and children especially when it came to inheritance patterns. Male primogeniture was embraced in England and France in the early twelfth century but it had been the preferred inheritance 
pattern for wealthy families even before that. This inheritance pattern resulted in a preference for sons over daughters and older sons over younger born sons. With this type of inheritance, parents invested heavily in the oldest son but otherwise chose which of their younger sons and their daughters to invest in and how much investment to give.

This dissertation will examine hypotheses pertaining to child survival, parental investment, marriage, and fertility and reproductive success using data collected on approximately ten-thousand individuals. Chapter 2 "Theory" will examine evolutionary approaches to the overarching question of parental investment, including how this investment may manifest in terms of child survival or child status. Questions relating to paternal and maternal investment will also be addressed. In the last part of the chapter, marriage as parental investment will be examined. Chapter 3 "Historical Background" will discuss the historical background of medieval Europe, specifically society in England and France in the eleventh, twelfth, and thirteenth centuries. Marriage practices as well as inheritance patterns will be examined. Chapter 4 "History of Focal Families" will focus specifically on the families that make up the database. A brief history of all fifteen families will be included as well as extensive family genealogies that were created using the collected birth, death, and marriage data. The methods used to collect the data will be discussed thoroughly in Chapter 5 "Methods." Statistical analysis of the collected data will be available in the "Results" Chapters. Chapter 6 "Child Survival" will discuss factors that impact child survival including birth order and gender. Chapter 7 "Parental Investment", will examine the use of secular and religious titles, along with estate size, as means of parental investment and how the bestowal of these attributes is affected by birth order and gender. Chapter 8 "Marriage" will examine consanguineous and affinal 
marriages and the age of spouses at marriage. Chapter 9 "Reproductive Success" will discuss fertility patterns over multiple generations in the focal population and note differences in reproductive success based on birth order and gender. Chapter 10 "Discussion and Conclusions" will give an overview of findings and implications. 


\section{Chapter Two: Child Survival, Parental Investment and Marriage}

\section{Introduction}

Life history theory provides a framework within evolutionary ecology with which to examine the trade-offs that are created with the allocation of energy toward fitness. Fitness refers to the passage of an organism's genes to the next generation. Life history theory examines key events in an organism's lifetime from an evolutionary perspective: birth, marriage, reproduction and survival (Borgerhoff Mulder 1992; Chisholm 1993; Hill 1993; Hill \& Kaplan 1999; Low 1998; Mace 2000; Clarke \& Low 2001; Shenk 2013). These events in an organism's lifetime are all shaped by natural selection and have the purpose of producing the highest number of offspring that will survive, and ultimately reach sexual maturity themselves (Hill 1993). Harris and Uller (2009) indicate that reproductive investment should be high if the expected fitness returns are also high. For example, evolutionary theory indicates that sons will have greater reproductive success than their sisters. Greater reproductive success for a son will translate into a greater number of grand-offspring for the parents. Therefore, evolutionarily parents should invest more in the offspring (sons) who will bring them the greater number of grandchildren. As a result, any factors that can cause a decrease/increase in expected returns will have the potential to impact reproductive decisions. In response to these factors, organisms select behavior that will allocate resources to reproduction (Houston and McNamara 1999).

There are two ways in which to enhance fitness: invest in traits that affect survival and invest in traits that affect fertility. This investment or lack of investment will impact the inclusive fitness of the organism. However, investment comes at a cost. Investing in 
certain traits may have a negative impact on other traits. For example, if an organism chooses to increase their investment in their fertility, by increasing the number of potential mates, energy must be taken away from other traits that could aid in survival. By choosing to increase parental investment in offspring, an organism may reduce their own survival or their future fertility (Giudice et al. 2015).

The allocation decisions made in the trade-offs of current versus future reproduction, quality versus quantity of offspring, and mating versus parenting efforts collectively make up an organism's life history strategy. Life history strategies are defined by three fitness traits: age at maturity (age at first reproduction or menarche), age-specific fertility (age at last reproduction or menopause), and age-specific survival, each of which will impact allocation decisions (Giudice et al. 2015).

\section{Trade-off between current and future reproduction}

The trade-off between current and future reproduction can be explained as such: by allocating energy to future opportunities, i.e. the production of offspring in the future, an organism is drawing energy away from their potential to produce offspring and/or care for current offspring. Investing in offspring is expensive; requiring massive amounts of energy to ensure their survival. Organisms will capture energy or resources from their environment. The rate at which they are able to capture resources will determine the energy budget available to them. This energy budget can then be "spent" in three different ways: growth, maintenance, and reproduction. Growth will allow an organism to increase the amount of resources they are able to collect which in turn will increase future fertility. Energy spent through maintenance occurs when organisms repair somatic tissue, increase immune function, and increase energy production. Finally, through reproduction, 
an organism will replicate their genetic material. Each of these draws on the energy budget creating a trade-off that will impact their life history.

Humans specifically have a long juvenile period when their fertility is zero. As humans age, maintenance and growth will become a drain on the energy reserves and will in turn impact future reproduction. This creates a trade-off between current and future reproduction. Williams (1966) referred to this loss of future fitness, capture of energy, and reproduction as a result of a shift of energy distribution to current reproduction as the cost of reproduction.

If a parent invests in their current offspring, it is coming at the expense of their potential future offspring. An individual who is young or early in their reproductive career will have a low reproductive value. This means that they could potentially delay reproduction until they have greater access to resources or invest more in their current offspring with the idea that future reproduction is still a possibility. If however, an individual is later in their reproductive career and has a higher reproductive value they will truly face this trade-off because they can either invest in the offspring they currently have, or reduce current investment with the idea of future returns on additional offspring. Here, there are two key factors, availability of resources and age. As an individual ages, senescence occurs and the likelihood that they will reproduce decreases, especially for women whose reproduction will be terminated by menopause.

At what point should an individual cease reproduction and invest in current offspring at the expense of future offspring? Cessation of reproduction has the potential to limit inclusive fitness. Hawkes et al. (1998) however, indicate that grandmothers may actually be able to increase their fitness even after menopause. Instead of investing in 
their own offspring, grandmothers can invest in their grand-offspring and as a direct result affect their own fitness. Increased investment by grandmothers was found among the Hadza. Here grandmothers were seen increasing their foraging efforts and provisioning for their grandchildren especially after the birth of a new grandchild. Kaplan et al. (2000) however, showed a lack of support for the grandmother hypothesis in several other well-documented hunter gatherer societies such as the Ache, Hiwi, Aka, and !Kung. Trade-off between quality and quantity of offspring

Much like the trade-off between current and future reproduction, organisms are faced with a second trade-off, to invest in offspring quality or in offspring quantity. Giudice, et al. (2015, p. 90) explained the tradeoff between quality and quantity of offspring as: "it is adaptive to increase investment in the quality of existing offspring until the fitness return on investment equals the return of a comparable allocation of resources to fertility;" the production of additional offspring. Ornithologist David Lack was one of the first to test this question using the clutch size of birds. He found that "clutch size has evolved through natural selection to correspond with the largest number of young for which the parents can on the average find enough food" (Giudice, et al. 2015, p 32).

Numerous studies have examined this trade-off in historical as well as contemporary populations using a proxy such as job success, socioeconomic status, and health to represent the quality of offspring (Kaplan et al. 1995; Voland and Beise 2002; Walker et al. 2008). Strassmann and Gillespie (2002) found that among 167 women of the Dogon of Mali, there was a decrease in offspring survival as the number of offspring increased. However, larger studies such as those by Pennington and Harpending (1988), 
Hill and Hurtado, (1996), and Borgerhoff Mulder (2000) all indicated that among the !Kung, Ache, and Kipsigis respectively, there was no evidence for this trade-off. Instead they found that as the number of offspring increased the number of surviving offspring also increased. In comparison, Meij et al. (2009) found that among the population of the Garu-Tempane district of eastern Ghana, survival of offspring decreased as the number of offspring increased.

According to Lawson and Borgerhoff Mulder (2016) the trade-off in quality and quantity of offspring can be examined using three dimensions: offspring survival, offspring capital, and offspring reproductive success. In small scale agrarian and historic populations high fertility has been found to compromise offspring survival (Strassman and Gillespie, 2002; Gillespie et al. 2008; Meijet al. 2009). Smaller inter birth intervals were also found to impact offspring survival. Blurton-Jones (1986) demonstrated that among the !Kung, smaller inter birth intervals were detrimental to offspring survival. However, Draper and Hames (2000) found a positive association among the !Kung between sibship size and fertility due to assistance in food acquisition, assistance in childcare, and support.

Borgerhoff Mulder (2000) found that among the Kipsigis, the quality of offspring was more important for females than it was for males. In this culture, the inheritance for male offspring was related to their mother's position and house-property settlement patterns. Males on the other hand, based their mating and marital decisions on maximizing the number of offspring they produced. This meant that most men married polygynously, but in order to do so, they had to be able to provide wealth equally to all of 
their wives and offspring. The result was varying reproductive success and a reproductive strategy that was tied to wealth and status.

Industrial societies with higher income levels experience declining fertility rates. Becker and Lewis (1973) argued that this trend could be accounted for because parents will achieve success through both the quality and the quantity of their offspring. Lower quantity (fertility) will be offset by the greater amount of resources parents will be able to provide per offspring. In modern societies, this investment has been measured in the form of school performance, education and adult income (Harpending, and Rogers 1990; Downey 2000; Goodman et al. 2012).

Gillespie et al. (2008) found that among individuals living in pre-industrial Finland, females from landholding families produced a high quantity of offspring and were able to maintain the quality of those offspring. Females from landless families however, experienced a decline in offspring quality as the quantity increased. This trend continued in the next generation where the offspring of wealthy females provided a higher quantity and quality of grand-offspring than their less wealthy counterparts. This suggests that females with greater resources could not only increase their own fecundity, but also the fecundity of their offspring, thereby increasing their overall fitness.

High fertility costs on offspring quality seem to be offset by offspring quantity in the benefits offspring receive as a result of being part of a large sibship. Using strategies of biased investment such as primogeniture and ultimogeniture, restricting age at first marriage, or even prohibiting offspring marriage, instead of fertility limitation, parents were able to solve the dilemma between offspring quality and quantity (Lawson and Borgerhoff Mulder 2016). Biased parental investment may have been especially 
important in historic populations where infant mortality rates were high and it was unclear how many offspring would actually survive to adulthood.

Sibling competition can create limitations on fertility, but this is most often seen in societies with heritable wealth. Mace (1996) and Borgerhoff Mulder (1998) found a correlation between sibling competition and reproductive success in the Gabbra, a group of east African pastoralists. While having an older brother impacted the reproductive success of younger brothers, having an older sister did not seem to impact the reproductive success of younger sisters. In a 2011 study conducted by Gibson and Gurnu in rural Ethiopia, it was concluded that where land was inherited, younger brothers had smaller farms and lower reproductive success than their older brothers.

\section{Trade-off between mating and parenting effort}

Reproduction is costly and may involve the expenditure of substantial energy through displays, exposure to danger, and competition with rivals. It will also involve a trade-off between mating and parenting (Williams. 1966; Trivers, 1972). In most organisms, males will invest more in mating by competing with other males for access to females. Females in comparison, will invest more in parenting. Females will benefit from male competition because the successful male will most likely also be the fittest. At the same time, males will also benefit because they will have access to additional females and more potential offspring.

Reproduction can also lead to conflict between males and females and between parents and children (Hager and Johnstone, 2003). The cost of reproduction is magnified if offspring are already present. Conflict will develop between parents and offspring 
when additional offspring are added to the unit. In order to provide the energy for reproduction, the energy given to offspring may decrease. This is due to the fact that current offspring now have to compete with the new offspring and the amount of investment that is now diverted. Trivers (1972) suggested that mating effort and parental investment will therefore compete and present a trade-off where the cost/benefit of an additional mating must be compared to the cost/benefit (reduction of fitness) for current offspring.

\section{Male Provisioning Hypothesis}

The male provisioning hypothesis indicates that males play a more significant role in the provisioning of their offspring than other members of society (Marlowe 2001). But why would males provision calories for (potential) mates? Females are more likely to mate with a male who can provide for them and their offspring (current or potential). In hunter-gatherer societies, better hunters have the potential of obtaining better or additional mates. This creates competition between males over females. By investing in offspring, are males also investing in their mating strategy?

The male provisioning model suggests that marriage emerged due to the increased demands of reproduction including a longer juvenile period and female demand for guaranteed provisioning before additional matings could occur (Winking 2006). By increasing the level of paternal investment, i.e. male provisioning, in offspring, maternal investment, per offspring, could then decrease and allow females to invest in future offspring. This would translate into additional offspring for their mate.

Male provisioning can also take a more indirect form. Among the Ache, males engage in meat sharing where they provide the meat they have procured, not to their own 
offspring, but rather to other members of the band. Kaplan et al. (1984), and Hill and Hurtado (1996), and found that children of good hunters or those that participated in meat sharing were more likely to survive in the absence of their father. In more complex societies this mating and parenting effort can also be seen. Boone (1988) indicated that among the Portuguese nobility, high ranking fathers invested heavily in both their sons and daughters, providing titles, land, and social connections, and dowries respectively. Burley (1986) predicted that when paired with high quality males, females would increase their mating investment as long as the cost of reproduction remained high. Females who are paired with high quality males should also increase their allocation of resources to the offspring thus affecting both male and female fitness (Sheldon 2000; Qvarnström and Price 2001). The reproductive compensation hypothesis (Bluhm and Gowaty 2004; Gowaty et al. 2007; Gowaty 2008) suggests that females who are paired with low quality males will invest more in mating investment than those paired with high quality males.

Moeller and Thornhill (1998) found that among female birds, females with higher reproductive value would have greater access to the more attractive males. But, it would come at a cost. Females would pay for mating with the more attractive males by investing differentially in their offspring (the differential allocation hypothesis). This was dependent on the frequency of extra-pair bondings. When the frequency of extra-pair bondings was high males reduced the amount of paternal investment as the rate of paternal uncertainty increased. At the same time, as the frequency of extra-pair bondings increased, females would also increase their maternal investment in an attempt to gain 'good' genes for their sons. Females that mated with more attractive males would 
produce more attractive sons. These sons would then have the potential of producing more attractive grand-offspring. Fisher (1958) referred to this as the 'sexy son hypothesis.'

Both life history theory and parental investment theory focus on tradeoffs between current investment in offspring and investment in future offspring as well as a tradeoff between quality and quantity of offspring. By investing in current offspring, the level of investment available for future offspring decreases. This is turn may decrease the reproductive success of the parent. To counteract this, parental investment will decrease per offspring in order to maximize the number of offspring (Kaplan \& Gangestad 2004). Differential parental investment, based on gender or birth order, may increase the parent's reproductive success (Boone 1986, 1988; Hrdy 1992).

\section{Parental Investment}

Parental investment is a key correlate of life history theory and is investment in current offspring at the expense of future offspring. Life history theory examines key events in an organism's lifetime from an evolutionary perspective: birth, reproduction and survival (Borgerhoff Mulder 1992; Chisholm 1993; Clarke \& Low 2001; Hill 1993; Hill \& Kaplan 1999; Kaplan \& Gangestad 2004; Low 1998; Mace 2000; Shenk 2013). Parental investment is a key correlate of life history theory and is investment in current offspring at the expense of other, including future offspring (Trivers 1972). Reproductive value, the number of offspring one can expect to produce in in its remaining lifespan, and the number of existing offspring and their investment needs can also determine the level of parental investment (Fisher 1958). 
Parental investment is defined as any investment by the parent in an individual offspring that increases the offspring's chance of surviving at the cost of the parent's ability to invest in other offspring (Trivers 1972). According to Trivers (1972), this creates a trade-off where parents should invest in their offspring only when the benefits of investing outweigh the costs. From an evolutionary perspective, the amount of time a parent invests in their offspring should be dependent on the likelihood that the offspring will provide grand-offspring.

Parents will invest in their offspring both indirectly and directly (Qvarnström and Price, 2001). Indirect parental investment will take the form of genetic inheritance. The quality of this inheritance will vary greatly and is dependent on the quality of the genetic material which will impact things such as growth rate. Direct inheritance involves contact involvement. A parent will provide their offspring with resources (nutrients, protection, social position or status) while in-utero as well as after birth. It is virtually impossible to separate indirect and direct investment. It would be like trying to separate nature and nurture. Each will be impacted by the other.

Offspring that are provided indirect and direct investment will have a lower mortality rate than those that do not receive the investment. Why would parents be willing to pay this cost? Parents are willing to pay the cost of investment because if their offspring survive they will be more likely to reproduce as adults thereby increasing the parents' fitness.

Parental investment will vary based on multiple factors. Initially, investment from both females and males will be biological. Females will have a high initial investment in the form of conception, pregnancy, and lactation. Bateman (1948) suggested that females 
invest more energy in reproduction than males because females have a limited number of ova while males have a potentially unlimited number of sperm. This also leads to continued female investment in their offspring while male investment will vary greatly.

\section{Maternal Investment}

Maternal investment is more intensive initially than paternal investment and will continue throughout the life of the offspring. Mothers invest in their offspring at higher rates than fathers cross culturally (Hames 1988; Hawkes et al. 1997; Hrdy 1997; Holden et al. 2003). Hames (1988) found that among the Ye'kwana, mothers held or carried their child $78 \%$ of the time while the fathers only held or carried the child $1 \%$ of the time. Quinlan (2007) examined the relationship between altered levels of parental investment and changes in the environment, specifically measured by famine, warfare, and disease. Based on these criteria, maternal investment differed from paternal investment. Maternal investment was measured by the proximity at which the mother slept from her infant, her response to the crying, and bodily contact between mother and child. Paternal investment was also measured by his sleeping proximity to the infant, but also his involvement with the child when it was an infant and his involvement in the infant's childhood. Mace (2000) also found there was a correlation between the level of investment in offspring and material inheritance. In families with a greater number of children, parental investment (inheritance) per child would decrease. In comparison, families with a smaller

number of children would experience a greater level of parental investment (inheritance) per child. So, families with a smaller number of children could actually increase their wealth by dividing the family resources among fewer people. 
Almost all mothers generally invest in their offspring. However, Hrdy (1999) and Voland (1998) found that the amount of maternal investment will vary cross-culturally based on the availability of resources (food, wealth, presence of kin, and paternal investment in offspring). Mothers who had abundant resources, had a high rate of paternal investment, and were healthier, could invest more per offspring than mothers who did not have access to abundant resources, had decreased paternal investment, and were less healthy. In this example, the mothers could choose to reduce or even cease investment in a certain offspring.

Inter-birth intervals can also be used to determine parental investment in offspring. Borgerhoff Mulder (1992) found that longer inter-birth intervals were associated with higher levels of investment resulting in higher quality offspring. Shorter inter-birth intervals were associated with lower levels of investment resulting in a higher quantity of offspring. A significant difference can be found in inter-birth intervals based on subsistence strategies. Foraging societies have greater inter-birth intervals than agricultural, pastoral, or stratified societies. Numerous studies have found a relationship between child mortality and spacing of inter-birth intervals (Lee 1979; Blurton Jones 1986, 1987; Mace 1996; Gibson and Mace, 2006).

\section{Paternal Investment}

Maternal investment is greater initially and will continue throughout the juvenile period of the offspring while paternal investment is more variable. In societies that are classified as forager groups and modern societies paternal investment is higher than in horticultural groups where investment is more variable. The Aka were found to the have 
highest level of direct paternal investment with fathers holding and playing with their offspring at rates that nearly rivaled the investment of the mothers (Hewlett 1991). In other cultures, the role of paternal investment is minimalized. Sear and Mace (2008) found that decreased paternal investment did not have an effect on child survival. Among the Martu, an aboriginal culture of Western Australia, paternal investment did not impact child survival, but it did impact the social competitiveness of male offspring (Scelza 2010). Males whose fathers were not present experienced delayed age initiation rituals when compared to males whose fathers, older brothers, or other male relatives were present. Specifically, the presence of the biological father meant that initiation occurred more than a year earlier than in the other described cases. Age at initiation was also closely associated with future reproductive success. Males who were initiated at a younger age had their first child earlier than their counterparts (Shenk and Scelza 2012). According to Winking (2006) three models best explain paternal investment: the provisioning model, the mating effort model, and the fertility model. The provisioning model suggests that marriage evolved in response to the demands of reproduction and potential future pairings. The mating effort model further suggests that men entered into marriage in order to gain and secure access to female fertility. The fertility model then suggests that a male presence allows the female to decrease her investment in current children (because she has the additional investment from the male) and instead focus on investment in future children. By investing in the female during courtship, the male is signaling that he should also invest heavily in future offspring. Therefore, paternal investment allows for reduced maternal investment in individual offspring and increased investment in future offspring, i.e. additional pregnancies. 
Marlowe (2000) argued that paternal investment developed out of male-male competition and mate-guarding. The result was an ecologically imposed mating system that would favor either polygyny or monogamy. He proposes two theories on the emergence of polygyny: resource-defense and harem defense. Males will defend their territories. The number of females they will be able to support will be dependent on the quality of the territory and the number of resources available (resources defense). Males may also defend females directly instead of defending resources (mate-guarding).

According to Marlowe (2000), the higher the paternal investment, the more likely the mating system will favor monogamy. In this situation, females can 'resource shop' and choose males that have the greater access to resources which will translate into reproductive success and higher quality offspring. At the same time, in a society with a higher rate of male-male competition, paternal investment may be lower (due to the divergence of energy to defense) and polygyny may emerge. Females in this case may be more interested in 'gene shopping' i.e. shopping for the male who is most likely to win in a case of male-male competition. A male who is successful in such a competition may indicate stronger genes which will also translate into higher quality offspring. According to Verner and Wilson (1966), the point at which a female can rear as many young alone or with only limited male investment in a good territory as she could with full male investment is referred to as the polygyny threshold.

Polygyny also requires a shift in behavior because while it gives males greater access to females, it also creates competition. By creating male-male alliances, men will have greater control over resources (females) due to the sheer strength in their numbers. This will result in hierarchical relationships based on the accumulation of wealth or 
goods. Females will become submissive to the male alliance and hierarchy. Marvin Harris (1977) argued that polygyny was based in large part on the presence of internal warfare. This required men to work collectively to protect their resources. In order to keep the males together, patrilocal residence and patrilineal descent will emerge. The constant fighting will require a reward (polygyny).

Geary (2005, p. 487) argued that in order to understand paternal investment, it is necessary to understand the evolution of this process. The evolution and maintenance of human paternal investment must involve trade-offs between benefits to children, paternity certainty, and lost mating opportunities.

\section{Benefits to children}

Trivers (1972) found that if paternal investment did not have an effect on the survival rate or the quality of the offspring then male abandonment would have been selected for. If however, paternal investment does improve offspring survival/quality then increased investment would be selected for and abandonment selected against. Studies have shown a correlation between paternal investment and offspring mortality rates (Hill and Hurtado 1996; Blurton-Jones et al. 1997; Marlowe 2001; Hewlett 2004).

Among the Ache, Hill and Hurtado (1996) found that 1 out of every 3 children died before reaching adulthood (15 years of age). There were also significant differences in mortality rates for children who had present versus absent fathers. Children with present fathers (to age 15) had a mortality rate of approximately $20 \%$ while children with absent fathers (to age 15) experienced a mortality rate of greater than $45 \%$. In developed countries a similar pattern was found. Children whose parents were married experienced lower mortality than children whose parents were not married. Socio-economic status 
also impacted child survival in developed countries, with income and occupational status important indicators of socio economic status. Adler et al. (1994) found in modern populations that individuals who are classified as having lower social status have higher morbidity and mortality rates.

\section{Paternity Certainty}

Determining paternity can be difficult as a result of internal fertilization and gestation. Therefore, males need some type of assurance that they are genetically related to the offspring before they invest in them. The insistence on female virginity at marriage could be one method that males can use to ensure a pre-marital pregnancy has not occurred. Dickemann (1979) argued the emphasis on female virginity led to practices such as foot-binding in ancient China, females being accompanied by a male relative when in public, modest dress restrictions, and female confinement.

In some societies, females are also an important commodity that can be used by men to secure political alliances. Among the aristocracy of medieval Europe this was a common practice. Fathers or brothers of unmarried females would arrange their marriages with more powerful, politically connected males. To ensure these marriages occurred, the fathers and/or brothers would guarantee the marriage payment was completed, in the form of a dowry, and the female's virginity would be assured. In many societies, the lack of virginity could result in an annulled marriage.

Multiple studies have also shown the emphasis females and their families place on paternal certainty at the time of birth. Daly and Wilson (1982) and Regalski and Gaulin (1993) found that among Canadian and Mexican families respectively, fathers were systematically told the child resembled them by both the mother of the child and the 
maternal grandparents. This can be further complicated by another study completed by Wilson et al. (1980) where they found that children who have stepparents are more susceptible to higher rates of abuse and higher mortality than children living with their biological parents.

How can females ensure male investment in their offspring? One possible adaptation can be found in the idea of partible paternity. Partible paternity is the idea that the sperm of more than one male is required to create a fetus. Men who have sex with a woman prior to her conceiving are thought to have contributed to the development of her fetus. As a result, each one of those men is thought to be the biological father of the child and as such each will invest in the child. This practice was found among several South American populations in Amazonia. But, how does this impact paternal uncertainty? Walker et al. (2010) found in a comparative study of 128 South American societies, that partible paternity was used to cement male alliances and secure access to additional females. Therefore, even if there was a decline in paternal certainty, there was an increase in the number of mating's so males could actually increase their fitness using this system. In turn, this may be a female adaptation that ensures the investment of multiple males in her offspring. This could increase the survival of the offspring.

Post-marital residence strategies and lineal descent may also impact the significance of male investment. In matrilineal societies in West Africa for example, males move at the time of marriage so related females will remain in the natal home. They can all provide care to the offspring, either their own or through alloparenting. In patrilineal and patrilocal societies however, infant and child mortality is closely tied to the presence of the father. In the Ache example mentioned previously, at the first sign of 
the child's birth, the new husband rejected the child by leaving the camp. Once the child was born, the older women of the group stated it was necessary to bury the child because it did not have any hair. Clearly infanticide was not chosen due to a lack of hair, it was because the child did not have a father (Hill and Hurtado 1996).

\section{Mating opportunities}

If males engage in paternal investment, this will limit the number of mating opportunities available to them. Is there a correlation between paternal certainty and limited mating opportunities? Concealed ovulation in human females requires males to invest in a relationship for longer periods of time to ensure that conception has occurred. By investing additional time and resources in a single conception males may reduce the number of mating opportunities they have available. Once conception occurs males are no longer tied to that female if paternal investment was selected against. Miller and Fishkin (1997) found that mechanisms such as pair-bonding could explain the additional investment males were willing to make.

Fieder and Huber (2007) found a relationship between socioeconomic status, education, and the number of offspring produced. As the wealth and level of education for men increased so too did the number of offspring produced. The opposite was true for women where there was a correlation between higher socioeconomic status and lower fertility. The authors argued that this was due to female choice. By selecting a higher status/higher level education male, females were investing in future offspring that could in turn produce higher numbers of grand-offspring.

The amount and type of investment parents give to their children will vary cross culturally. Parental investment has been examined in numerous populations with varying 
levels of complexity (Boone 1986, 1988; Cronk 1991; Low 1991; Hrdy 1992; Mace 1996; Mace and Sear 1998, 2012; Hewlett 2014). Among the Aka, Hewlett (1988) and Hewlett et al. (2014) found that low status fathers invested more direct parental care in their children than did high status men. Specifically, low status men held, coddled, and fed their children nearly $80 \%$ of the time compared to high status fathers who only interacted with their children approximately $10 \%$ of the time. While low status fathers could not provide their offspring with social status they could provide them with a strong kin network. High status fathers on the other hand were able to give their offspring social status and social connections.

A much different pattern was found among the Ache. In the Ache little direct paternal investment occurs. Hill and Hurtado (1996) showed that fathers spent as little as 10 minutes each day in direct parental investment. Walker et al. (2012) found that in some South American cultures, men engaged in partible paternity, with several men investing equally (or nearly equally) in the offspring of women they had engaged in sex with.

\section{Alloparenting}

Another important of aspect of investment in offspring is alloparental care. Alloparenting, cooperative breeding, is found in some form in most societies. Kramer (2010) asserts that cooperative breeding may be an adaptation to deal with shorter inter birth intervals, higher rates of survival, and dependent children of various ages among humans. Alloparenting is any form of parental care provided to an offspring by an individual other than their parents. Most often alloparents are related to the child, often maternal kin. Mace and Sear $(2008,2012)$ found that maternal kin were more important 
to the survival of young children than paternal kin. Hawkes et al. (1998) argued that grandmothers provided a large amount of alloparental care to their grandchildren, especially upon the birth of a new grandchild (the grandmother hypothesis). Voland and Beise (2002) also found support for the grandmother hypothesis in and eighteenth and nineteenth century German population where maternal grandmothers reduced the rate of infant mortality especially within the first year of life.

Ting et al. (2013) provide an example of cooperative breeding amongst a Chinese population. In this example, the females mated polyandryously (visiting husbands). As a result, men invested more heavily in their sister's offspring than in their own wife's offspring. With their sister's offspring, there was maternal certainty, but with the wife's children there was a high degree of paternal uncertainty. This pattern shifted as the sister's children began to age and get married themselves. The degree of relatedness (Hamilton's rule) decreased because the man would then be more closely related to the individuals living in his wife's natal unit (potentially his offspring) than his niece's children.

In hunter gatherer societies, other forms of alloparental care were found. Among the Aka, Hewlett et al. (2014) found that individuals became 'helpers at the nest' providing care, especially for infants and very young children when their mothers were foraging for food. The authors also found that Aka infants were occasionally wet nursed (nursed by another women, not their mother) in the absence of their mother. Hill and Hurtado (1996) discovered that among the Ache, the children of men who had established themselves as good hunters, taken part in meat sharing, and secured social alliances were more likely to be taken care of in the event that their father was killed. This was 
especially true for older children, but not necessarily so for infants. This could be due to the amount of care required by the child, or the fact that a father of an infant has not had time to establish himself with the qualifications previously listed. Kaplan et al. (2000) determined that if the child of a good hunter was sick, the band was more likely to stay in camp until the child recovered.

In traditional societies, such as the hunter gather cultures mentioned above, alloparental care may be impacted by the availability of kin and kin networks. In matrilineal, matrilocal societies (of which few hunter gatherer societies are) women who are related are more likely to engage in alloparental care. In a patrilineal and patrilocal society where related women are not living in the same area, but may live in close proximity to each other, they are also likely to take part in alloparental care. However, women living in a patrilineal and patrilocal society where female relatives do not live in close proximity, will be less likely to take part in or have their children receive alloparental care. This is especially true in societies where there is a high degree of paternal uncertainty. In these societies, kin related by marriage may not be as willing to invest in children that may or may not be genetically related to them. In societies with a high degree of paternal certainty, paternal kin may be more willing to provide alloparental care.

In some cases, those that are providing care are not related to the child. In western societies, for example, it could be argued that daycare is a form of alloparental care. In a market economy, parents are required to be away from their children for long periods of time as they earn the money (resources) necessary to survive. This has resulted in the rise of childcare facilities that care for children for long periods of time. The result is 
childcare workers who have taken on the role of alloparenting, often spending more time/investment in the child than the parent. In more extreme examples, foster parents and boarding schools could also be classified as examples of alloparental care.

In stratified societies, it is more common for non-kin to alloparent. Among the elite in numerous societies, nannies or governesses were hired to care for the children. It was also common for infants to be wet-nursed (discussed in greater detail below) especially among the wealthy. Elizabeth Fox-Genovese (1988) found that among the planter elite of the Antebellum South female slaves were given the care of their master's children, including the nursing of infants.

Hawkes et al. (1997) discussed the grandmother hypothesis as a possible explanation for the evolution of menopause among human females. Menopause ends the reproductive career of human females, and reduces the amount of maternal investment. The end of fecundity may seem to be counterproductive. Women no longer invest in their own offspring, but women who have reached menopause, typically over the age of 50, may be able to contribute to their own inclusive fitness by assisting their daughters in the raising of offspring. By providing assistance, mothers are potentially increasing their daughter's fertility and increasing the likelihood that their grandchildren will survive (Coall et al. 2014).

Hawkes et al. (1998) found that among the Hadza, maternal grandmothers were instrumental in increasing the nutritional status of their grandchildren. This was especially true when a new infant was born. As the maternal investment shifted toward the new child, maternal investment toward existing children decreased. It was at this time that grandmothers were the most important -to supplement the decreased maternal 
investment and the loss of calories experienced by the young. As the children aged (and became more self-sufficient), the significance of the maternal grandmother began to decrease.

Sear and Mace (2008) agree that maternal grandmothers are an important alloparental resource. However, they also found that maternal grandmothers are the most important up until the age of weaning and then paternal grandmothers become more important for the first years of life. This is due, not to direct child investment, but rather investment in the mother of the child. For example, paternal grandmothers may affect child mortality by affecting the condition of the mother. Interestingly, paternal grandfathers were found to be the least important to the survival of the children. Coall and Hertwig (2014) found a similar pattern among a contemporary European population. Maternal grandmothers were the most important to child survival followed by the maternal grandfather. The paternal grandmother came next followed lastly by the paternal grandfather. This was due to paternity uncertainty which would be magnified in a grandoffspring. In each step the certainty of paternity decreases.

Johow (2011) found that grandparental investment among an eighteenth century German population, differed based on the sex of the grandparent and the sex of the corresponding grandchild. Paternal grandmothers were more likely to invest in their granddaughters than they were their grandsons. Maternal grandmothers were more likely to invest in their grandsons than their granddaughters. Therefore, boys would receive greater investment from their maternal grandmothers and less from their paternal grandmothers while girls would receive a higher amount of investment from their paternal grandmother and less from her maternal grandmother. 


\section{Wet-nursing as alloparental care}

Wet-nursing, the nursing of infants by women other than their own mothers, was a common practice found in numerous cultures. In hunter-gatherer societies, it is not uncommon for an infant to be fed by another woman especially if the mother is not present. With the emergence of stratified societies, wet-nursing became more formal. The earliest written example of wet-nursing can be found in Sumeria and dates to approximately 3000 BC. Wet-nursing was found among the ancient Greeks and Romans and by the eleventh century, members of the French and English aristocracy had adopted the practice. According to Fildes (1986) by the twelfth century, the number of wet nurses had increased significantly. Wet-nursing would last until the late nineteenth century, when advances in medicine began to show the correlation between breast feeding, disease resistance, and reduced child mortality. In addition, this also correlates with the introduction of scientific formula feeding in industrial societies.

In some cultures, the relationship between wet-nurse and infant is secured under law. In Arab culture for example, Islamic law allows for three types of kinship: by blood, by marriage, and by milk (Hrdy 1979). A wet-nurse may even be able to expect some type of compensation from the nursed child once they are of age. It was not uncommon to find a reference to a wet-nurse in a will. In some cases a child may have had a deeper personal connection with their wet-nurse than with their parents as seen in provisions made for wet-nurses in wills and land grants.

Cultural norms in some societies dictated that elite women should not nurse their own offspring. Wet-nursing was prominent especially among high status women, although evidence suggests that lower class women also hired wet-nurses for their 
children. McLaren (1979) indicated that the majority of elite (specifically high ranking aristocratic) women refused to feed their own children because it was degrading if they had to suckle their own infants. Instead they would hire women from the lower tiers of the aristocracy or even lower-class women to suckle their infants. Hired wet-nurses often had their own children to care for so they would either hire their own wet-nurses or send their offspring to foundling homes. In some cases, wet-nurses may have also lost their own nursing infants. This decreased form of parental investment then had a domino effect with both the offspring of the elite and the offspring of the wet-nurse receiving less parental care.

According to Stone (1977) and Kilday (2013), the employment of a wet nurse by a family had a high probability of leading to death by neglect. Even among wealthy families, once a child was sent out of the natal home, little monitoring of the child was done. Other than the exchange of funds, little contact was maintained with the wet nurse. If the child survived, once they were weaned he or she would be returned to their natal home.

Casual opportunistic cooperation among women, often affines or consanguinal kin, may indicate the origins of wet-nursing. A mother leaves her nursing child in the care of her female relative, who is also lactating, while she works for an hour in the field and in her absence the child must be fed which her female relative would provide. This is not formalized, but opportunistic. The female relative does not expect payment from the mother of the child; rather this is a reciprocal relationship where the mother of the child may find herself in a similar situation. 
Sarah Hrdy (1992) indicates that wet-nursing can best be understood as a strategy to reduce the costs of reproductive effort for individual mothers. It provided an alternative to outcomes such as the death of an infant and maternal destitution. Delegated mothering is often seen in other animal species, but the justification for the development of wet-nursing among historic populations may have three possible explanations: 1) a nursing infant reduces a mother's foraging or labor opportunities thus making her dependent on others for support, 2) wet-nursing may reduce the physiological costs of lactation, especially the necessary increase of caloric intake 3) social norms which encouraged wet-nursing. In the first two explanations, the mother would experience greater reproductive success either due to the improved survival prospects of her infant or by reducing her inter-birth intervals. Some cultures also encouraged wet-nursing such as in Renaissance Italy where it was believed that air in the city was bad for the survival of infants. Aristocratic mothers would often send their infants to wet-nurses in the country (Giuffra and Fornaciari 2013).

In medieval Europe, infant and child mortality rates were high (Volk and Atkinson 2013). Because of this high mortality rate and because of the inheritance pattern of primogeniture which dictated the need for a male heir, aristocratic women spent the majority of their married lives either pregnant or recovering from childbirth. In the first decade of marriage for example, nearly annual births were common. For example, William Marshal and his wife Isabel de Clare (the progenitors of the Marshal family included in this study) were married in 1189, had their first child in 1190 and over the next 13 years produced a total of 10 children. In the second decade of marriage, if the mother survived her multiple pregnancies, then she may have experienced an increase in 
the inter-birth intervals, but her birth rate would have still been high. On average, aristocratic women gave birth to a child every 18 months and could produce as many as 16 children over the course of their reproductive lives. Anne of Brittany (d. 1514) spent most of her married life pregnant with her children being born on average 14 months apart. Between 1492 and 1498 she had a total of seven pregnancies. Only one child survived infancy and that child had died by his third birthday. In her second marriage to Louis XII, king of France, she experienced nine pregnancies in thirteen years. Only two of those nine children survived infancy.

Many women would continue to produce children until they died in childbirth. Bonne of Luxembourg, the first wife of John II, the second Valois king, died at the age of 34 after giving birth to her ninth child. Eleanor of Castile, the wife of Edward I, the second Plantagenet king of England, died at the age of 49 after giving birth to her $16^{\text {th }}$ child.

In comparison to elite women, peasant women on average bore 3-4 children in their reproductive careers and had 3-5 year inter birth intervals. Overall, elite women produced more offspring and in a much shorter amount of time, but it came at a significant cost to their health. The numerous births, led to health complications and potentially early mortality.

Medical treatises of the twelfth century (Treatises on Medicine 1145) suggested an infant should be nursed by its own mother regardless of the cultural norms (Leyser 1995) Religious authorities also encouraged mothers to care for their own children and not hire the services of a wet nurse. According to Leyser (1995), the refusal of a mother to breast-feed her own child was considered a type of blasphemy, by the Church, and 
could be severely punished. In one extreme clerical view, women who chose to use a wet nurse instead of breast-feeding were accused of attempted murder. Whether this was in response to the increase in maternal mortality and child abandonment that was associated with wet-nursing is not clear.

Only in extreme cases was it acceptable to hire a wet nurse, if for example the mother had died in childbirth, or if the mother was not physically able to care for the child. Even if the mother was not able to feed the child she was still expected to provide as much care as possible, including swaddling, cuddling, and holding the child. Despite the medical and religious prohibitions, the use of wet nurses employed by elite women increased significantly by the thirteenth century (Fildes 1986). As fewer children were nursed by their own mothers, the inter-birth intervals decreased and there was an associated rise in fertility (Hrdy 1992).

This increased fertility caused additional problems because the preferred inheritance pattern of primogeniture encouraged small families. Too many children born into a family could lead to competition over resources that in turn could led to a division of the familial resources and a decline in the overall social standing. As a result, elite parents would often choose which child or children they wanted to invest in more heavily. By choosing to send a child or certain children to a wet nurse elite parents could choose who they wanted to invest in more heavily. In a 2014 paper I presented at the Mid America Medieval Association Conference I argued that males would receive preferential treatment over their female siblings. Three options emerged for males: 1) they were nursed by their mothers, 2) a wet nurse would be brought in to reside with the family and nurse the child in situ, or 3) a higher quality wet nurse would be chosen. For males, these 
options were also dependent on their birth order with higher birth order males receiving higher quality wet nurses and lower quality males receiving lower quality wet nurses. In comparison, females would be 1) sent out of the natal home and reside in the home of the wet- nurse or 2) be given poorer quality wet-nurses.

In order for a women to become a wet nurse she clearly must have (or have had) a nursing infant of her own. But, what happened to her child? In most cases the child of the wet nurse would either be sent to their own wet nurse or it would be abandoned, often to Foundling Hospitals. By the fourteenth century, this practice had become so widespread that Foundling Hospitals in France recorded infant mortality rates as high as 90 percent in some years. For the next four centuries, this would be an accepted practice. By the eighteenth century, however, the number had decreased to nearly $20 \%$. This number was similar to the mortality rates of infants' breastfed by their own mothers (Sussman 1982).

The increase in the usage of wet nursing can also be associated with an increase in maternal mortality. By definition, maternal mortality relates to the death of a woman while she is pregnant or within 42 days of the end of the pregnancy. The death must be related in some manner to the pregnancy and cannot have occurred as a result of natural causes. Maternal mortality rates were high throughout medieval Europe. Fildes (1986) found that as late as the sixteenth century, 1 in 40 women died from childbirth or an associated illness. There was also a high number of stillbirths and miscarriages associated with maternal mortality. Two hundred out of every 1000 children born in the medieval world died before their fifth birthday (Fildes 1986). 


\section{Child Survival}

The effects of birth order on reproductive success and child mortality rates have been studied in a number of agricultural based historic populations. Low (1991) found that in nineteenth-century Sweden, older brothers depressed the reproductive success of their younger brothers. Among the eighteenth and nineteenth century Krummhörn farmers, Voland and Dunbar (1995) found that male infant mortality was influenced by birth order. Specifically, the more male siblings in the family, the higher the male infant mortality rate. Having three or more older brothers increased infant mortality prior to the first birthday to nearly $20 \%$, as compared to $12.5 \%$ male infant mortality for the general population. A similar pattern was also found for females with older sisters. Females with three or more older sisters experienced an infant mortality rate of nearly $27 \%$. This was in comparison to an infant mortality rate of $5-10 \%$ for females who only had one or two older sisters.

People living in the Krummhörn practiced the inheritance system of ultimogeniture with the youngest son inheriting the family land. Voland and Dunbar (1995) indicate that the Krummhörn residents adopted this system due to environmental and geographic limitations. Given their geographic location with the Black Sea surrounding them on three sides and moors on the other, they could not feasibly divide the land amongst all of their sons. As a result, older sons often left the natal home to look for other opportunities. By restricting inheritance to the youngest son, fathers were able to accumulate additional resources, land and wealth. The youngest son was then responsible for providing his older siblings, both male and female, with financial settlements and dowries respectively. The more siblings he had the more settlements he 
would have to distribute. Therefore, it was in the best interest of the family for the parents to limit the number of offspring they produced. An excess of offspring would result in a rapid disbursement of the family wealth. In this example, it seems that residents of the Krummhörn could maximize their fitness by minimizing the number of offspring produced, but maximizing the familial resources.

In this same culture, a preference for daughters emerges. A daughter's inheritance portion was half that of her brothers. By reducing the number of inheriting males, and concentrating on female survivorship, Krummhörn farmers could limit the amount of resources being divided while also ensuring the survival of the lineage by marrying daughters into other land-owning wealthy families.

\section{Reduced Parental Investment}

What happens when a parent wants or needs to reduce the amount of parental investment? Under certain circumstances, parents may choose to reduce or cease the amount of investment they provide to their offspring. One option is fostering. Pennington and Harpending (1993) found fostering to be a preferred method of diverting parental investment among African societies. Here an infant or child can be sent to distantly related kin to be fostered. At some point parental investment may resume.

Abandonment is the second method that can be used to reduce parental investment. In medieval and early modern Europe children were abandoned in foundling homes. According to Hrdy (1992) this was essentially the same as engaging in infanticide because the mortality rates were so high in the foundling homes. The mortality rates were nearly fifty percent in some cases due to the overcrowding and lack of care experienced in the foundling homes. 
Wet-nursing is another example of reduced/diverted parental investment. Wetnursing is a practice that is seen in numerous cultures, but it is often viewed through the lens of alloparenting. Among hunter gatherer societies for example, it is not uncommon for another women to nurse an infant if the child's mother is not in camp (See discussion in wet-nursing as alloparental care).

The extreme example of diverting parental investment is infanticide. In cultures that practice infanticide, other methods of reducing parental investment are not available. Among Amazonian cultures, for example, rates of infanticide vary between 12-40 percent (Hrdy 1992). In these cultures, fostering is not an option because foster parents (alloparents) would face the same if not more challenges in trying to care for additional offspring than the parents. Hill and Hurtado (1996) relate an account that was observed during fieldwork with the Ache, a hunter-gatherer society in Paraguay. This account relates the story of a newborn who was killed through infanticide, not as an act of brutality, but rather as an act of mercy because the likelihood that the child would survive was very slim. In this account, a young father-to-be was killed while hunting and his wife was heavily pregnant. She remarried quickly within just a few days, but when she went into labor her new husband left the camp. This signified his lack of acceptance of the child. At its birth, the baby was not held by other members of the group, indicating that it was not accepted as a member of the tribe. Some of the older women dug a hole to bury the baby in because it 'had no father.' The mother of the child did nothing because it was clear that the child was not going to be accepted as a member of the group and she would not be able to care for herself and the child without the assistance of her tribe members. 
In this example, it was in the best interest of the mother's fitness (potential future offspring) to abandon the child.

Infanticide is counter to simple perspectives on evolutionary theory and the idea that organisms are programmed to replicate their genetic material in the next generation. If you kill an infant would this not limit the fitness of the parent? According to Daly and Wilson (1981), there are three causes that will lead to infanticide and decreased parental investment: paternal uncertainty, decreased offspring quality, and lack of parental resources. Males will invest in their offspring if paternal certainty is present. In the previous example, the new husband was obviously not the father of the child, so what incentive would he have to invest in another male's genes?

A birth defect can result in a decline of parental investment in an infant. According to Daly and Wilson (1981) this is the second possible explanation for the evolution of infanticide. An abnormality, real or perceived, can also lead to a decline in parental investment. For example, an infant born breech could be considered an abnormality or suggest there is a defect with the child.

Infants are especially susceptible to infanticide if they are part of a multiple birth. Multiple studies have found that twin births are interpreted as a bad omen and one or both of the infants will be killed at birth. In an eighteenth century German population, Gabler and Voland (1994) found that twins and their mothers had higher rates of mortality than infants born in single births or their mothers. Ball and Hill (1996) further evaluated twin infanticide and found that many cultures engaged in the practice not as a cultural trend, but rather as a means of parental investment. Twins create twice the nutritional burden on the mother and by killing one infant (or both depending on other factors such as inter 
birth interval and number of older siblings) mothers may actually be increasing the chances of survival for their other children.

Lack of paternity can also be tied to infanticide. Daly and Wilson $(1984,1988)$ found among twenty societies, non-paternity was seen as an explanation for infanticide. In those societies, cuckoldry was the most common reason given, followed by children whose biological father was from outside of the group, and then those children who were the result of the woman's first marriage. Daly and Wilson (1994, p.385) also found that between 1977 and 1990, in England and Wales, 117 children under the age of 5 were beaten to death by alleged fathers and 103 by stepfathers. Weekes-Shackelford and Shackelford (2004) also found that in the United States children under the age of five were beaten to death by their stepfathers at a rate of 55.9 per million children. While children under the age of five beaten to death by their biological fathers was 5.6 per million children.

The third factor identified by Daly and Wilson (1981) as a precursor to the development of infanticide is the lack of parental resources. If parents do not have sufficient resources to provide for their offspring, is it in the best interest of the parent to practice infanticide and conserve what resources they do have and put those into future offspring? Voland (1988) found there was a correlation between infant mortality and the remarriage of their mothers. This was especially true if the infant was the first child. Infanticide most likely occurred prior to the remarriage. By reducing or eliminating parental investment in the current offspring, mothers were able to focus their attention on producing additional offspring, offspring that would have paternal investment. 


\section{Biases in Parental Investment due to Sex and Birth Order}

Both life history theory and parental investment theory focus on tradeoffs between current investment and investment in future offspring as well as a tradeoff in quality and quantity of offspring. By investing in current offspring, the level of investment available for future offspring decreases. This in turn may decrease the reproductive success of the parent. To counteract this, parental investment will decrease per offspring in order to maximize the number of offspring (Kaplan \& Gangestad 2004). Differential parental investment, based on gender or birth order, may increase the parent's reproductive success (Boone 1986, 1988; Hrdy 1992).

Parental investment, through the allocation of specific resources, may favor the survival of certain offspring (Hartung 1982; Dickemann 1979; Rohde et. al 2003, Hopcroft 2005; Lawson and Mace 2011, Lawson et. al. 2012). In societies where there are established inheritance patterns, such as primogeniture, for massive amounts of wealth, sex-biased parental investment may emerge. This investment can take many forms: direct investment, i.e. investing in the physical well-being of the offspring or indirect investment such as the conferring of social status, the transfer of titles, wealth, and land (Boone 1986, 1988).

Sex allocation theory (Fisher 1930, 1958) predicts that sons and daughters are equally costly and are produced in equal numbers resulting in a 50:50 sex ratio. With an even sex ratio parental investment will not vary in relation to the gender of the offspring. However, Hamilton (1967) suggested that sibling competition for resources (mates, inheritance, status) may actually create a situation where parents may benefit from producing offspring from the opposite sex which will limit said competition. Parental 
investment is not static; parents may invest differentially in their offspring in specific cases or under certain conditions (Hopcroft 2005). In populations where certain resources are scarce, inheritance patterns may also be adopted that will favor one sex over the other. As a result, parental investment may shift toward one sex or the other.

Trivers and Willard (1973) argued that parents would bias investment toward those offspring that have the greatest potential for survival and reproduction. Depending on the condition of the parents, this could vary based on sex of the child. Selection would favor parents in good condition who invested more heavily in sons while those parents in poor condition would invest more in daughters (Trivers 1972; Cronk 1991). The ideas of sex determination and sex ratio were first introduced in Europe in the fifth century by Isidore of Seville (Barney et al.2006). This introduction was based largely on the works of Aristotle. Aristotle wrote, "females are generated by the very young or very old; or by the moister-bodied; or when the south winds prevail" (quoted in Rubin 1997). Therefore, according to Aristotle, females who are in poorer condition (classified as the very young or the very old) would produce more female offspring while females in better condition (those in prime childbearing years) would produce more male offspring.

Aristotle also wrote: "in mankind...more males than females are born defective, in other animals not" (Aristotle; Generation of Animals). According to Peter Biller, by the twelfth century, the ideas of Aristotle, including sex ratio and sex determination, had permeated the European scientific world (Rubin ed. 1997).

While parental investment, the amount of resources parents invest in their offspring, is a common factor found across all human societies, the degree and type of parental investment is not. Parental investment, through the allocation of specific 
resources, may favor the survival of certain offspring (Rohde et. al 2003, Lawson and Mace 2011, Lawson et. al. 2012; Hopcroft 2005; Hartung 1982; Dickemann 1979). For example, a preference for sons is found in societies where there are established inheritance patterns for massive amounts of wealth (Boone 1986, 1988). Sex-biased parental investment can take many forms: direct investment i.e. investing in the physical well-being of the child or indirect investment such as the conferring of social status, the transfer of titles, wealth, and land.

Studies indicate that elite parents are more likely to invest in sons than in daughters (Boone 1986, 1988, Hrdy 1992, Hrdy and Judge 1993, Hager 1992). This investment can take several forms; the conferring of wealth, land, even social status. Sons are more likely to receive high parental investment than daughters based on inheritance preferences. Sons will inherit land and titles, while daughters will receive dowries upon marriage. By investing in sons over daughters, elite parents were theoretically limiting their own reproductive success. However, by choosing which children to invest in and how much, parents may have been maximizing their reproductive success by expecting long-term fitness benefits from sons (Boone 1986, 1988; Hrdy 1992).

Boone's (1988) study examined differential parental investment in high and low ranking lineages of fifteenth and sixteenth century Portuguese nobility. He found that men who were classified as part of high-ranking lineage had greater reproductive success than their low ranking counterparts. They were also more likely to marry (more than once) and have illegitimate children. Parental investment differed significantly for the daughters of low ranking men. Low ranking females experienced greater social mobility, often marrying up the social ladder, something that was restricted for their male siblings. 
This pattern created an excess of daughters amongst the high ranking lineages. These excess daughters were referred to as "Brides of Christ" because they were often cloistered in convents (Duby 1977).

Primogeniture was one of several inheritance patterns found in central France. It was not enforced as all sons received a share of their father's estate. In order to preserve the lineage however, only the eldest son was allowed to marry and produce offspring. Those offspring in turn would inherit the familial shares from their uncles. . A similar pattern was found among the Venetian nobility. One son married and the other sons joined the Church and also left their inheritance to their nephews (Cooper 1976). Male primogeniture, as an inheritance pattern, is a successful means by which to maintain a family's access to limited resources, but it can also have a negative impact on individual reproductive success.

Local resource competition may occur in circumstances where resources are abundant, but unevenly distributed (Shenk 2103). This competition may transpire on the family level or the individual level. Conflict may occur when individuals compete for access to resources such as inheritance (land, wealth, titles), or access to mates. McCullough et al. (2006) found that competition over the throne of England led to the elimination of several members of the same family.

Local resource competition may also occur between parents and offspring, or between offspring when both are competing for the same resources. In these circumstances, parents may shift their investment in favor of those offspring that are not in competition (Clarke 1978; Silk 1983; Hrdy 1992). When the sons of Henry II, King of England 1154-1189, rebelled against him, he sided with his remaining loyal sons as well 
as his illegitimate son. Henry's sons later reconciled with him, but he never again trusted them. Voland et al. (1997) found that in nineteenth century Germany, parents invested more heavily in sons when land was available on which to establish farms. The opposite was true, with a preference for daughters, when land was limited. Among the Portuguese nobility, Boone $(1986,1988)$ found that there was a preference for older sons and older daughters, who received parental support in terms of land, titles and larger dowries respectively.

Siblings of the same sex may also compete for access to local resources. Limited resources will impact the level of parental investment, with older siblings sometimes receiving higher levels of parental investment than their younger counterparts. Differential parental investment may take the form of limited access to inheritance. Among European royalty, primogeniture was the accepted inheritance pattern with the eldest son being the recipient of the throne and the associated wealth, titles, and power. European inheritance patterns, being born from Salic Law, dictated that only sons were eligible to inherit the throne. As a result, sons were the preferred offspring. Royal parents therefore invested heavily in first born and elder sons, while investing less in their younger sons. Elder daughters also received preferential parental investment in the form of marriage payments (dowries) (Fleming 1973; Gaulin \& Boster 1990; Boone 1986, 1988; Kroll \& Bernard 1990; Stone 1977; Voland et al. 1991).

Humans are unique in that we have large numbers of dependent offspring all at the same time. The number of offspring will determine the amount of resources available to each offspring. From an evolutionary perspective, parents will want to invest in their offspring in order to increase their own inclusive fitness. Life history theory posits 
individuals will be faced with a series of tradeoffs that will impact their reproductive success. These tradeoffs include the investment in current offspring versus investment in future offspring and the quality versus the quantity of offspring. Parental investment can be defined as the amount of resources parents invest in their offspring. Resources include anything that helps an individual survive and eventually reproduce (access to food, alliances, education, and wealth, especially land and titles). The availability of resources will determine the number and quality of offspring and will impact the level of parental investment.

In an environment where resources are scarce, parental investment will likely be concentrated on current offspring, while in an environment where resources are abundant, parental investment may be divided between current offspring and the production of additional offspring. Age may also be an influential factor in parental investment. An individual who is early in their reproductive career will have a high reproductive value. This means that they may invest in their current offspring, but there is always the potential to invest in additional offspring. As a result, the level or amount of parental investment may suffer. On the other hand, an individual who is later in their reproductive career will have a low (lower) reproductive value. In this case, they will want to invest in the offspring they currently have and not invest in any future offspring.

The amount and type of parental investment will also vary. Among the Aka, a group of hunter-gatherers in Northern Africa, low status fathers invest more parental care in their children directly than do high status fathers (Hewlett 1988). Low status fathers have been observed to hold, cuddle, and feed their infants as much as $80 \%$ of the time, while high status fathers have little to no contact with their children (as little as 10\%). 
Hewlett found that while low status fathers could not provide their offspring with social status they could provide them with a strong kin network. High status fathers on the other hand were able to give their offspring social status and social connections. A much different pattern was found among the Ache (Hill and Hurtado 1996) where fathers spent as little as 10 minutes each day in direct parental investment. Walker et al. (2012) found that in some South American cultures, men engaged in partible paternity, with several men investing equally (or nearly equally) in the offspring of women they had engaged in sex with.

Under certain circumstances parents may choose to invest differently in their offspring based on sex and even birth order. Trivers-Willard (1973) argued that the condition of the parents would determine the amount of investment offspring would receive. Parents would invest in the offspring that had the potential to bring them (the parents) the highest inclusive fitness. In other words, parents in good condition would invest more in their sons while parents in poor condition would invest more in their daughters.

Studies indicate that elite parents are more likely to invest in sons than in daughters with a preference for first born sons (Boone 1986, 1988; Hrdy 1992; Hager 1992; Hrdy and Judge 1993). However, under certain circumstances parents may choose to invest differentially in their offspring based on sex and birth order. In eleventh-century Spain, only one son was encouraged to marry and in France between the twelfth and fourteenth centuries 77 percent of eldest sons were married compared to only 39 percent of younger sons (Betzig 1995). Boone found that among fifteenth and sixteenth century Portuguese nobility, 80 percent of first born sons were married while only 30 percent of 
fourth born sons were married (Boone 1988). Whiteman et al. (2012) argued that the benefits of younger siblings not reproducing outweighed their total investment cost. While in most cases parents will invest preferentially in their sons over their daughters, there are some exceptions. The higher the birth order, the less parental investment sons will receive.

Dunbar (1991) found that among a group of Hungarian Gypsies mothers invested more in their daughters than in their sons. Cronk (1988) also found that among the Mukogogo a group of pastoralists in northern Africa that parents were more likely to invest preferentially in their daughters. In both cultures daughters were able to marry into the neighboring populations while the sons were not.

Voland (1988) found that among a population of farmers in northern Germany, parental investment varied based on the availability of land. When land was readily available parents invested heavily in their sons. Land was passed from father to son with small parcels being given to all sons. This land remained intact and was tied to the social status of the family. However, as land became scarce, parents shifted their investment away from sons and towards daughters. By investing in their daughters, parents were able to arrange hypergynous marriages that would bring prestige to the family.

Boone $(1986,1988)$ found a slightly different pattern among the Portuguese nobility. High nobility invested heavily in their sons, with an emphasis on first born sons. Primogeniture was the preferred inheritance pattern. Lower status nobility invested more in their daughters rather than their sons. Here too parents used their daughters to arrange for hypergynous marriages. By marrying their daughters up, possibly to the sons of the 
high nobility, they were able to bring additional power, prestige, and social connections to the family.

Duby (1978) found that in France women of marriageable age were the means by which to secure political alliances. At the same time, he also argued that male heirs were more likely to wed while younger sons, referred to as cadet sons, were less likely to marry and were forced into careers in the military or the church. A similar pattern was found among the English royal houses. Sons were more likely to remain unmarried than daughters (Hollingsworth 1957). Boone (1986) found that among the Portuguese nobility, elder daughters were more likely to marry than their younger counterparts. This was not necessarily true in this sample. There was an even distribution of marriage occurrence across birth order. The difference occurred in the titles of the actual marriage partners. Elder sisters were more likely to marry someone with a more substantial title than their younger sisters.

Stratified societies with heritable wealth will have a much different pattern in parental investment than egalitarian societies. As soon as private property becomes available, parents will invest in their children in a manner that allows them to secure the passage of property. Heritable wealth can take many forms: land, livestock, money, titles, or other forms of wealth. Social status can also become part of the transmission of wealth from one generation to another. For example, among the aristocracy of medieval Europe, eldest sons inherited their father's land, titles, wealth, and social standing through primogeniture.

Parental investment in children can vary based on birth order and sex. Among members of elite social classes, greater emphasis is placed on first born children, 
especially sons. In societies with heritable wealth, sons are most often the children that will inherit the bulk of the property. Dickemann (1979) found this pattern among the elite in medieval Europe. Eldest sons received higher levels of parental investment than their younger male or female counterparts.

Dickemann (1979) also found that among the Rajput in India, there was a preference for sons over daughters. Female infanticide was such a common practice that males within the society had to look outside of their culture to find marriage partners. She found a similar pattern in China. In the 1940's the preference for males was exacerbated by the government's policy of one child per couple. Females were either abandoned or killed in record numbers. Cronk (1988) found a different pattern among the Mokogodo with a preference for daughters instead of sons (sex ratio was 86:126 males: females).

Hrdy (1992) found a preference for sons and differential parental investment among the late medieval-early modern aristocracy of Europe (see Boone 1986). The elite would selectively send their children out to a wet nurse based on the birth order and gender of the child. Elder sons were less likely to be wet nursed than their younger brothers. Second sons were more likely to be wet nursed, but the nurse would be brought to the natal home. Daughters were more likely than sons to be wet nursed. Even then there was a preference given to older daughters over younger daughters. Hager (1992) found that by founding or endowing convents where daughters could be placed, medieval families limited the movement of familial resources while at the same time creating political and spiritual alliances. According to Livingston (2010) aristocratic families were able to establish ecclesiastical dynasties which extended their power and control. 
Daughters could be used to make and cement alliances. In medieval Europe, political alliances were a necessity. The virtue of women was also an important factor in securing a political alliance (and the legitimacy of her husband's heir). This competition for females led in some cases to early betrothals and child marriages. Edward VI of England was betrothed to his cousin Mary Queen of Scots in infancy although the marriage never took place. Richard II, the last Plantagenet king married his second wife when she was just six years of age. The marriage was never consummated and the king died three years later.

Like elder sons who received preferential inheritance treatment from their parents, elder daughters also received preferential parental investment in the form of marriage payments (dowries) (Fleming 1973; Gaulin \& Boster 1990; Boone 1986, 1988; Kroll \& Bernard 1990; Stone 1977; Voland et al. 1991). Elder daughters received larger or more substantial dowries and better marital matches than their younger counterparts. Elder daughters were more likely to marry men with more substantial titles (king, duke) than younger daughters.

Transmission of wealth can take several forms: primogeniture (eldest child, often the eldest son), ultimogeniture (youngest child, often the youngest daughter), passage to a favored heir (usually a son), and distribution among all sons, all daughters or an even distribution among all heirs. In societies with heritable wealth, especially large amounts of heritable wealth, the most common practice is primogeniture with the eldest son being the chosen heir. In European cultures, the most common practice is for sons, especially elder sons to inherit. However, in some South Asian cultures, youngest daughters are the preferred heirs. 
Hrdy and Judge (1993) argued that primogeniture was an adaptive form of parental investment. By choosing to adopt the inheritance pattern of primogeniture, parents chose to invest in their elder sons over their younger sons and in their sons over their daughters. The result was that as many as $20 \%$ of younger sons and daughters did not marry. By investing in the elder sons though, parents exchanged the potential reproduction of their other children in exchange for a high payoff from one child. Younger sons and daughters were left with the option to invest in their sibling's offspring or they could join a religious order which would bring status to the family.

High status males are more likely to engage in polygyny than low status males. This is seen cross-culturally in societies both with and without heritable wealth. For example a shaman among a hunter-gatherer group is more likely to have multiple wives than other males. That does not mean that other men cannot have multiple wives, but they are just less likely to be able to support additional wives. High status males have greater access to multiple females which in turn will increase the number of children he produces. In societies with large amounts of heritable wealth, two marriage patterns may emerge, monogamy or polygyny. In most parts of the world high status males (those with the heritable wealth) will engage in polygyny. In western society however socially imposed monogamy is the most common practice.

Heritable wealth will also foster endogamous and isogamous marriage patterns. In some cultures, this may lead to incestuous marriages. Many ancient societies participated in this type of marriage. Van der Burgh (1992) found that among the Inca, the Emperor (called the INCA) had a single legitimate wife and many secondary wives or concubines. The rightful heir to the throne was a son who was the product of an incestuous 
relationship between the INCA and his primary wife who was also his sister. A similar pattern was found in Ancient Egypt. Hatshepsut, the first female pharaoh married her stepson, who was also her nephew in order to secure her position on the throne (Tylesday, 2009). This practice was also common in Spain through the eighteenth century. The ruling family of the Hapsburgs engaged in uncle-niece marriage. Eventually the family died out when the last Hapsburg ruler Charles VII, was so inbred that he was his own first cousin. Among the Tamil in South India uncle niece marriage is also common.

Ancient Egypt also had a similar marriage pattern; the pharaoh had a primary wife and many secondary wives. The children that were eligible to inherit wealth directly were the children of the first wife. Children of the secondary wives would have social status, but were not able to inherit seats of power. There were some exceptions to this; for example, Akhenaton and his primary wife Nefertiti only produced six daughters, so his heir became Tutankhamen, his son with a secondary wife. To secure the inheritance, Akhenaton married one of his daughters with Nefertiti to Tutankhamen (Dodson 2005).

Socially imposed monogamy will restrict the number of spouses an individual will have, but it can also foster polygynous matings. Men and sometimes women in societies with socially imposed monogamy may engage in polygynous matings. In Ancient Rome, the Emperor Augustus passed legislation that required people to marry and produce children. In addition he also made divorce much more difficult to obtain. Adultery was made illegal and was punishable by banishment or death. The Emperor Augustus' own daughter was banished for engaging in multiple affairs (Betzig 1992). In the eleventh and twelfth centuries in France, only the eldest sons were allowed to marry. 
Their younger brothers, the youths, were not allowed to marry, nor produce children. Instead they were destined for occupations in the Church or the military (Duby 1982). Youths were only able to marry if their older brother died. By the end of the twelfth century this pattern had changed and younger sons were able to marry. Duby attributed this change to an increase in the wealth of the families which allowed them to support cadet branches. Livingston (2010, pg.114) found that first born sons (primogenitus) oversaw the management of the patrimony.

Heritable wealth may come in different forms; the previous examples were cultures with extreme amounts of heritable wealth. In other examples, there may be lesser forms of heritable wealth, limited to small pieces of land or some limited wealth. In those types of societies, you may also see different marriage strategies. Among the Nayar of South Asia polyandry is more common. Women will engage in polyandry, with fraternal polyandry or visiting husbands. The women will stay in matrilocal residences and will raise their children cooperatively. The husbands will invest little in the offspring, but rather will invest more in their sister's offspring.

The Mukogodo, a group of pastoralists living alongside the Maasai in northern Africa are relatively recent converts to pastoralism. Traditionally they were huntergatherers, but because of outside contact they have become pastoralists. Like the Maasai they practice brideprice, to be paid at the time of marriage in the form of cattle. They are not able to provide the cattle necessary for their sons to marry. Therefore they invest more in their daughters who they are able to marry outside of the group, often to members of the Maasai culture. They are able to draw a brideprice for their daughters which they can then use as a brideprice for their sons. The problem however, according 
to Cronk (1988), is that the Mukogodo have borrowed cattle so often from each other in order to either get their sons married or to obtain additional wives for the elder males that any cattle they do receive are used to pay back their debts. The Mukogodo are an exception in that in most cultures where animals are part of heritable wealth, much emphasis is placed on sons because of the need to keep the sons together. In other pastoral societies, brideprice may be replaced by dowry. Amongst the Bedouin, for example, the exchange of females includes a dowry in the form of animals.

In agricultural societies, land becomes the method of wealth transmission. Wealth will be passed from generation to generation via the male line. In this system, greater parental investment will be given to sons. For example, farmers in India will engage in monogamous marriages with patrilineal descent and patrilocal residence. The men will marry and live in their family's bari with their parents, their elder and younger brothers, their wives and children. The eldest son will inherit the family farm.

Parental investment is not only tied to heritable wealth, but can also be tied to ritual, social, or caste status. The son of a shaman, a headman, or a bigman will have more status (not formal status) within their respective societies than their male counterparts. In another example, a member of the Brahman caste in India has a high status as a member of that caste, but their actual social class may be low compared to other Brahmans. The amount of parental investment will vary based on the cultural patterns of each.

Environmental factors and the availability of resources can impact an individual's reproductive success. Do parents also have the ability to control the reproductive success of their offspring? Apostolou (2007) argues that among hunter-gatherers, parents will 
exert considerable control over the reproduction of their offspring, especially their daughters. By choosing mates based on the male's ability to provide resources, parents can affect the reproduction of their daughters. Parental choice of mates is especially probable in societies where offspring are largely dependent on their parents for resources. This is based on the ideas of Trivers (1972) in that females are the scarcer resource and as such could potentially bring additional resource gains for the parents.

\section{Marriage in Evolutionary Perspective}

\section{Kinship}

Kinship is the most basic principle of organization in any human society. It classifies individuals into social groups, roles, and categories. In its simplest form, kinship can be identified as the relationship between kin and explained as relationships based on parentage and descent. People who are kin through descent are referred to as consanguine kin while kin who are related by marriage are referred to as affinal kin. Both descent and lineage are important aspects of kinship. Descent can be defined as the biological relationships between members of a kin group which are socially recognized by other members of the culture. Descent is traced through a lineage (ancestry).

Every kinship system consists of the following: 1) terms used to classify various categories of kin into consanguine and affinal, 2) terms used to identify kin that are more significant socially than others, and 3) an outline of expected rights and obligations that different categories of kin have toward each other. Kinship ties are fundamental to all humans and as a result exert incredible influence on all facets of society (Pasternak 1976). 
Kinship establishes unity and maintains cooperation between groups of people. It provides guidelines for communication and acceptable interaction between individuals. Rights and obligations are also defined. Membership within a specific kin group provides certain rights and outlines group obligations. Finally, kinship determines descent and defines lineage and ancestry. Lineage and descent will be of utmost importance in determining one's place in society. Murdock (1969) stated that kinship was the structured system of relationships in which kin are bound to one another by complex interlocking ties.

Schneider (in Parkin and Stone 2004, p. 263) identified the additional form of social kinship as "the degree of sharing likelihood among individuals from different communities... if two people have many similarities between them then both of them do have a bond of kinship." The major difference between consanguineal, affinal, and social kinship is that in the latter, there is the ability to absolutely terminate the relationship, i.e. you can pick your friends, but you cannot pick your family.

Fox (1967, p. 30-31) identified kinship as what man does with the basic principles of life: mating, gestation, parenthood, socialization, and siblingship. He argues that the process that led to the adaptation of kinship falls into four basic principles: 1) women have children, 2) men impregnate the women, 3) men usually exercise control, and 4) primary kin do not mate with each other.

Kinship has a significant impact on the structure of social order in all human societies. It is the basic social unit. Numerous studies have shown the significance of kinship ties throughout the world (e.g., McCullough and Barton 1991; Salmon and Daly, 1998; Salmon 1999; Neyer and Lang 2003). These networks are intricate webs of 
connections based largely on marriage. Dickemann (1979) found a strong correlation between kin networks and the formation of male alliances. Fields (2005) found among a colonial population in northern Virginia that kinship ties of blood and marriage created a complex pattern of familial networks which allowed the planter aristocracy to secure their place in the highest social class.

Kinship networks contribute to the homogeneity of a society as well as allowing for the social mobility of its members. Kinship creates a complex web of both consanguine and affinal kin relationships. With each succeeding generation this web became more complex. Rutman (1984, p. 120) described the growth of family relationships in Colonial Virginia as an expanding helix spiraling upward and outward with each new generation.

People who are related to each other, either by blood or by marriage should want to help each other. This is the idea of 'kin selection.' Hamilton (1964) identified kin selection as a predictor of human behavior. Preferential treatment should be given to relatives. Individuals who are related to each other should act altruistically toward each other. This behavior will be predicated on genetic relatedness with greater assistance being provided to those that are more closely related than to those that are more distantly related. As a result, one should be more willing to act altruistically toward relatives rather than non-relatives. Multiple studies have tested this premise and have found mixed results (Johnson and Johnson, 1991; McCullough and Barton, 1991; McCullough et al. 2006; Dunbar et al. 1995). Johnson and Johnson (1991) examined conflict within the English royalty from 1066-1745. They found that close biological kin (uncles and nephews, brothers, fathers and sons and daughters) were more likely to support each 
other in the face of conflict. McCullough et al. (2006) examined conflict within the English royalty during the Wars of the Roses. They found that when a prize, like the throne of England, was at stake people were willing to execute their own kin in order to secure the prize. However, the participants in the Wars of the Roses never killed lineal relatives nor did they execute collateral relatives in a number that was in excess of their own relatedness.

Another study (Fields 2005), indicated that among a founding population in colonial Virginia, kinship secured one's position within society. Rutman and Rutman (1984) found that in 1687, 17 percent of all relationships between heads of household in Middlesex County, Virginia involved a consanguine or affinal tie. By 1724, 64 percent of the population in the same county could be tied directly to five families.

Stanard (1979, p. 120) described the upper class as "one big, scattered family who were almost all related either by blood or marriage, and closely connected in all their interests," and "one great tangled cousinry that was a self-perpetuating oligarchy drawn from a few families." The genealogies of these Virginia families can best be described as a "tangle of fishhooks, so closely interlocked that it is impossible to pick up one without drawing three or four after it" (Fisher 1989, p. 220).

A similar patterns was found in this study. Of the fifteen families selected, there was at least one consanguine connection in each, as well as multiple affinal connections. Some of these connections were close by the laws of consanguinity and the church standards. For example, there were several cousin and affinal marriages that had to receive papal permission in order for the marriage to occur. For example, Eleanor of Aquitaine and her first husband, Louis VII, were twice second cousins. Their two 
daughters Marie and Alix married the brothers of Louis' third wife, Adela. Isabel de Ferrers, the granddaughter of William Marshal, married as her second husband Reginald II de Mohun who was her elder sister Joan's father-in-law. Under the church's marriage restrictions all of these marriages were prohibited without consent.

\section{Marriage}

Marriage arrangements can be found in all human societies. Marriage is a formal relationship that has been sanctioned by customs, rules, and obligations. It consists of formal relationships between parents and children, between spouses and their in-laws, and between the families of the bride and groom. Marriage is regulated based on specific sets of rules, customs, and norms that vary based on the society. This includes formal guidelines on who can marry whom and what type of marriage can occur (Westermarck 2003).

The purpose of marriage is to regulate sexual behavior and limit sexual competition. By regulating sexual behavior, marriage establishes legitimacy and social relationships for children born to a couple. This allows the creation, expansion, and reinforcement of social connections. Marriage will also provide the basis of householdbased sexual division of labor.

Marriage rules and patterns vary cross culturally, but virtually all societies have rules about whom one can and cannot marry based on kinship, lineage, class, or caste. For example, small scale societies have complex rules of kin exogamy. Tribal societies may emphasize clan exogamy, while stratified and large scale societies may practice endogamy (Bell 1997). 
Exogamous marriage refers to marriage outside of a particular group. There are certain benefits associated with this marriage practice. It reduces inner group conflict and leads to alliances with outside entities. By doing so, it promotes social cohesion within the culture. Partners may be chosen from outside of the lineage, the clan, or the social class. This does not necessarily mean that prospective marriage partners are from outside of the culture. For example, in north India, there is a preference for a marriage partner from outside of the village. The person may be from the same social caste, or even the lineage. Among several Native American groups clan exogamy, but culture endogamy is practiced (Bell 1997).

Endogamous marriage refers to marriage within a specific group. Choosing a marriage partner from within the same group may help maintain social identity. Social status and wealth may also be tied to maintaining these close relationships. Ideally when a marriage partner is chosen from inside a particular group, the members will be more compatible. In south Asia caste endogamy is common. Endogamy may also be based on race, class, religion, and lineage. In multiple historic populations, endogamy was the preferred marriage pattern (Bell 1997) (see discussion of royal intermarriage below).

\section{Incest Avoidance}

Why would the preference for choosing marriage partners extend to outside of a particular group? By bringing in 'outsiders' is this exposing the group to potential hazards? One possible explanation is related to the incest taboo, commonly called the Westermarck Effect. Multiple theories have been identified regarding the incest taboo. The Childhood Familiarity Theory was introduced by Westermarck (1894) where he argued that individuals who were raised either together or in close proximity to each 
other would have a natural aversion and lack of sexual attraction to each other.

Additional studies Talmon (1964) and Wolf (1970) examined marriage patterns in the Israeli Kibbutz and among a Chinese population in northern Taiwan that practiced the custom of raising a daughter-in-law from childhood respectively and found that in both examples there was reduced sexual attraction. But how does this account for brothersister marriages, or parent-child marriages that were seen in some historic populations (ancient Egypt, Inca, Japan, Korea, and Hawaii)?

Freud suggested in the Psychoanalytic Theory that the incest taboo was an innate reaction against incestuous desires. Sons are attracted to their mothers and will feel jealously and hostility toward their father as a result. However, because the son is afraid of his father, he will repress his feelings. This repression is what Freud argued led to the incest taboo (Ember 1975). Malinowski (1927) introduced the Family Disruption Theory, which suggested that sexual competition among family members would create rivalry. This rivalry would not allow the family to function as a single unit. Therefore, the incest taboo emerged as a means by which to restrict jealously among family members.

Slater (1959) (in Turner and Maryanski 2005) asserted in the Demographic Theory that the incest taboo could have its origins in the demographic characteristics of early human societies. He argued, the family units that could have been produced by incest would have been limited or restricted because of high mortality and sterility rates. This theory suggests that by the time a child was of reproductive age, their parent would have either died or would have become sterile and so could not mate with their own children. 
In the Cooperation Theory, first introduced by Tylor (1889) and White (1948), (in Turner and Maryanski 2005) the incest taboo was used to promote cooperation among family units. By enforcing an exogamous marriage practice, families and communities would be required to work collectively with people who may not have been related to them by blood. The Inbreeding Theory of the incest taboo is one of the oldest explanations. Strauss (1969) (in Turner and Maryanski 2005) indicates one of the earliest references was made by Pope Gregory I (590-604) in an attempt to regulate the definition of marriage by the church. Inbreeding theory focuses on the consequences (potentially harmful) of mating within one's own family unit.

Thornhill (1991) suggested that incest taboos had less to do with preventing sexual relations between kin and rather were intended to protect property, paternity, and status. A cross-cultural sample of traditional societies identified three rules regulating incest. First, the Westermarck effect provides an innate incest avoidance. Second, distant kin, those with an $\mathrm{r}$ value of greater than 0.25 are not included in this avoidance. R-value refers to the expected number of copies of each of its genes that are passed on to distant generations (Barton and Etheridge 2011). Marrying extended kin guarantees that the wealth stays within the lineage and has the potential of increasing its power base. Third, rules regulated sexual relationships between affinal kin. Thornhill (1991) argued this rule was designed to protect male paternity and prevent familial in-fighting.

Thornhill also found that the rules regulating incest and affinal kin differed between patrilocal and matrilocal societies. Patrilocal societies had much stricter affinal incest regulations than matrilocal societies. In these societies, paternal certainty was of utmost importance as was the proximity in which related males resided. As the 
complexity of societies increased, Thornhill noted that the rules regulating incest became more extensive. Levi-Strauss (1969) argued that exogamous marriage could be used as a means of avoiding incest regulations. In addition, this allowed for the foraging of alliances through the exchange of women.

Van den Berghe (1980) pointed out that while incest taboos inevitably reduce the level of inbreeding that occurs in societies, exogamous marriages may do the opposite. Multiple marriage systems regulate cross-cousin marriage allowing individuals to marry certain cousins while prohibiting the marriage of others. For example, a marriage may be allowed if the cousin is the mother's brother's daughter or the father's sister's son, but prohibited if the cousin is the father's brother's daughter or the mother's sister's son. All of these individuals are just as closely related and the level of inbreeding would be the same. For small scale societies such as the Yanomamo who practice bilateral cross cousin marriage (Chagnon et al. 2017) the level of inbreeding is increased.

Van den Berghe (1980) also argued that the need for alliances between lineages would overrule certain incest taboos and allow for the development of marriage practices that allowed for relative marriage. By allowing cross cousin marriages, family ties are maintained by creating links between two separate lineages (Levi-Strauss 1969).

Multiple examples of inbreeding and its effects (decreased fitness, physical and genetic abnormalities) can be seen in historic populations (van den Berghe 1983, Thornhill 1991, Ober et al. 1999). Among the ancient Egyptian royal families brothersister marriage was common. Akhenaten married his sister Nefertiti (conflicting evidence) and their son Tutankhamen married his own sister Ankhesenamun). Another 
Egyptian pharaoh, Hatshepsut, the first female pharaoh, married her stepson who was also her nephew in order to secure her position on the throne (Tylesday 2009).

Van der Burgh (1992) and Durham (1991) found a similar mating practice among the Inca. The Emperor (called the INCA) has a single legitimate wife and many secondary wives or concubines. The rightful heir to the throne was a son who was the product of an incestuous relationship between the INCA and his primary wife (his sister). Incest avoidance was also important in medieval Europe.

\section{Marriage and Status}

In many societies, especially non-Western societies, the choice of a marriage partner is incredibly complex. Hypergamy is the process of marrying someone who has a higher social status. This marriage pattern is most often seen in complex societies that have status differences.

Hypogamous marrying occurs when one partner has a higher status than the other. That individual will then marry someone of lower status. This is more common among men cross-culturally. In a hypogamous marriage, hypergamy has also occurred because one of the spouses is marrying up. Isogamous marriage occurs when both of the partners have equal social status. This is most commonly found in egalitarian societies or in cultures that have endogamous hereditary statutes.

The incest taboo, discussed above, indicates that individuals prefer to marry nonkin. But, in multiple cultural examples, the preferred marriage partner is a close relative. How can these cultures maintain the incest taboo and still marry close kin? One possible justification is cross cousin and parallel cousin marriages. Cross cousins are individuals who are the children of a parent's opposite-sex sibling. For example, a mother's brother's 
son or a father's sister's daughter would be a cross cousin. These individuals would be cross cousins in the first degree. This pattern has been found among the Crow, the Iroquois, and the Tamils in South India (Murdock 1949). In other cultures, parallel cousins may be the preferred marriage partner. Parallel cousins are the children of a parent's same-sex sibling. So, a mother's sister's son or a father's brother's daughter would be classified as a parallel cousin. Parallel cousin marriage is found most prevalently among pastoral groups.

Marriage partners may also be chosen from among affinal kin through levirate or sororate marriage. While not directly related (genetically related), prohibitions can also apply to these types of marriages. In the $12^{\text {th }}$ century, the Catholic Church began to restrict marriages between affinal kin. However, in non-western societies, these marriages prevailed.

Levirate marriages are common among the Tiv of Central and Southern Africa, among the Maragoli of western Kenya, the Nuer of Sudan, the Kurds, and the Karo people of Indonesia. This practice was common among the Huns until the $7^{\text {th }}$ century as well as among Jews in the Old Testament. Here a man marries the widow of his deceased brother or other close male relative. Sororate marriage is another form of marriage. In a sororate marriage, a man will marry his wife's sister if his wife is infertile or if she dies. This marriage pattern has been found among the Inuit, the Chiricahua Apache, the Sioux, the Swazi people, in ancient China as well as in Bhutan (Ingoldsby and Smith 2006). Both of these marriage practices make evolutionary sense. Any offspring produced either in the previous or subsequent marriages will share genetic material from the spouse encouraging them to invest in the offspring. 
Among the Germanic tribes that first settled in Europe and laid the foundation for the emergence of the centralized kingdoms of the eleventh, twelfth, and thirteenth centuries, polygyny was a common marriage practice especially among high-status males. A man could have as many wives as he could maintain, but he would also have access to multiple women as concubines. However, as wealth became more concentrated, the transition to monogamy began to occur. At about the same time, the Church began to impose restrictions on marriage. In response to religious pressures, monogamy became the accepted marriage practice throughout medieval Europe. Socially imposed monogamy will restrict the number of spouses an individual will have, but it will not restrict the number of matings. Regulation may actually encourage the rise of polygynyous mating. Among the population in this sample, monogamy was the only accepted form of marriage. But, while the men specifically married monogamously, they mated polygynously. Most if not all of the males in the sample population had illegitimate offspring either before or after marriage.

\section{Consanguineous Marriage}

Historically marriage between consanguineal kin was commonplace, especially in societies with large amounts of heritable wealth where the desire to maintain said wealth within the family was of utmost importance. According to Bittles and Black (2010), nearly $10 \%$ of the global population continues to practice consanguineous marriage (identified as second cousin marriage or closer). Many countries do not have any civil proscriptions on first-cousin marriage. Exceptions to this are the United States, China, and North Korea. Thirty-one states in the United States have laws against first-cousin marriage. China passed the Marriage Act (1981) which prohibited marriage between first- 
cousins. North Korea passed a law in 1994 banning consanguineous marriage (Ottenheimer 1996, Paul and Spencer 2008). While consanguinity was found among the wealthy elite in historic populations, Bittles and Black (2010) found that consanguineous marriage was more prevalent in poor communities. These communities experience lower levels of maternal education, earlier age at marriage and first birth, as well as shorter inter birth intervals resulting in higher rates of infant mortality and longer reproductive periods.

Consanguineous marriages can provide social and economic advantages. Consanguineous marriages are easier to organize, they potentially reduce the size of dowries, and traditionally have a lower divorce rate (Bittles and Black 2010, Bittles and Hamamy 2010). Consanguineous marriage has been practiced historically by multiple cultures. Marriage partners included cousins, uncle or niece, or on rare occasions a sibling. In the Eighteenth and Nineteenth Dynasties of ancient Egypt, sibling marriage was expected in the royal family. Incestuous marriages were also found among the Persian Zoroastrians as well as the Inca royal family. Half sibling marriages, first cousin marriages, and uncle-niece marriages were permitted in ancient Athens and Sparta (Ottenheimer 1996, Ager 2005). In Classical Rome, first cousin marriages were permitted, but such marriages were viewed negatively. The Roman view of consanguinity impacted the early Christian stance on cousin marriage. While the Romans had allowed first cousin marriage, between the tenth and twelfth centuries, the Church forbade marriages closer than the seventh degree of consanguinity. These restrictions would also apply to affinal kin. This will be discussed in greater detail below. 
The Roman and later Christian view on consanguineous marriage was in contrast to marriage guidelines provided in the Old Testament. First cousin and uncle-niece marriages were permitted in Leviticus 18:7-18. Among Sephardi Jewish communities’ consanguineous marriage is still the preferred marriage practice. Islam allows first cousin and double first cousin marriages, but uncle-niece marriages are not. In most Muslim countries, paternal cross-cousins are the preferred marriage partner (Bittles and Hamany 2010).

In Buddhism and Zoroastrianism first-cousin marriages are allowed by religious law. Laws regulating consanguineous marriage are more complicated in Hinudism. In North India, the laws are heavily influenced by the Indo-European tradition and the family pedigrees are examined for both the bride and groom. In order to prevent an incestuous marriage, as many as seven generations are examined on the female side (Bittles and Black 2010). In South India, especially among the Dravidian populations, maternal consanguine (mother's brother's daughter) marriage is preferred (Cooper and Zhang 1993).

In Confucianism individuals who share the same family name are prohibited from marrying. Marriage between paternal first cousins is prohibited (father's brother's daughter), but marriage is acceptable between maternal first cousins (mother's brother's daughter) (Cooper and Zhang 1993). Some populations are divided over consanguineous marriage. The Sikh living in Pakistan tolerate first-cousins marriage, but among Sikh populations living in other parts of the world first-cousin marriage is forbidden.

In several countries, there are no civil proscriptions on first-cousin marriage. Exceptions to this include China, North Korea, and the United States. In China, the 1981 
Marriage Law was passed which prohibited consanguineous marriage between firstcousins. North Korea passed a similar law in 1994 banning marriages between blood relatives. The United States has laws in 31 states that make first-cousin marriage a criminal offense (Ottenheimer 1996, Paul and Spencer 2008).

While consanguineous marriage is often associated with wealthy landholding elites, Bittles and Black (2010) found that the prevalence of consanguineous marriages was higher in poor rural communities. These communities tended to have low levels of maternal education, an early age at marriage, early age at first birth, shorter inter birth intervals as well as longer reproductive spans. They also found these factors were associated with higher rates of infant and child mortality.

In historic populations, as in modern populations, the concern over the inheritance of recessive alleles that could lead to mental and physical issues within a population may not be enough to prevent close marriage under specific circumstances. The classic example of excessive inbreeding can be found in the Hapsburg family in seventeenth century Spain (Figure 2.1). The preferred marriage pattern among the Spanish Hapsburgs was that of cousin marriage or uncle-niece marriage. By the time Charles II, the last of the Hapsburg rulers in Spain was born in 1661, 80 percent of all marriages were between close relatives. Charles himself was so inbred that he was his own first cousin. He was the product of successive generations of both first cousin and uncle-niece marriages. 


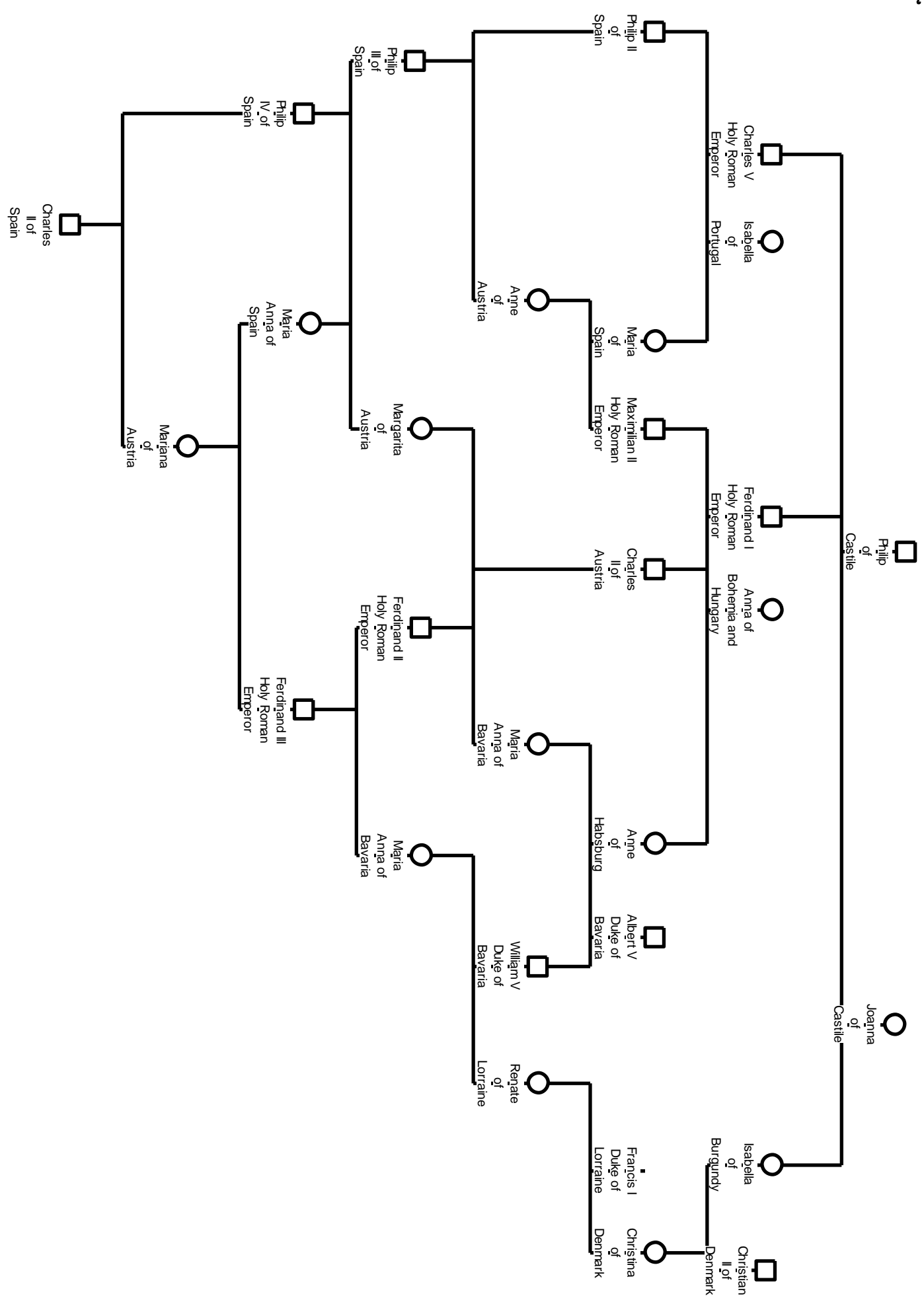

Figure 2.1 Hapsburg Family Tree Created by author using Geno Pro 


\section{Extensive and Intensive Kinship Systems}

The decision to marry consanguineous kin (or not) is a tradeoff. If marriages occur within a social network, class, or family, the involved parties will strengthen their already existing connections. This may come at the cost of preventing the establishment of new connections. Societies with heritable wealth, land and/or status, may encourage close familial marriages.

Walker and Bailey (2014), Bailey et al. (2014), and Shenk et al. (2016), found that agricultural societies (those with heritable wealth) tended to have higher rates of consanguineous marriage than most foraging cultures. This pattern was identified as the result of extensive versus intensive kinship systems found within the respective groups.

Extensive kinship systems encourage exogamous marriages and will result in a much larger kin network than an intensive system. Foraging groups may be more interested in expanding their connections through the formation of extensive kinship systems. The lack of heritable wealth in these societies may be replaced by the need to reduce risk and secure greater access to resources. As a result, exogamous marriages may be more prevalent. By not practicing consanguineous marriage, the kinship network can be expanded considerably.

Intensive kinship systems, on the other hand encourage marriage alliances between lineages. Levi-Strauss (1949) found that intensive kinship systems led to an increase in cross-cousin marriages and other close kin marriage as seen in the Hapsburg family tree above. Agricultural and state level societies with large amounts of heritable wealth (land, titles, status) may favor an intensive kinship system. Here consanguineous marriage may be preferred in order to secure the transfer of property within the family 
and with as little division as possible. In this system, it would be more important to strengthen the existing social network instead of expanding it. Multiple studies have indicated the importance of having kin living in close proximity which provides for the protection of resources (Alexander 1974; Hill and Hurtado 1996; Kanaiaupuni et al. 2005; Borgerhoff Mulder et al., 2009).

In Europe, intensive kinship systems were the norm with varying degrees of kin marrying. However, by the twelfth century, the Church had begun to place restrictions on kin marriages. Schulz et al. (2019) found that the Church's restrictions on marriage led to the decline of the intensive kinship and its replacement by a non-intensive (extensive) kinship system that encouraged non-kin marriages. The definition of kin was also extended to include step-relatives, in-laws, and spiritual kin (for a complete explanation of marriage prohibitions see Chapter 3). Chapter 3 will examine the history of medieval Europe in general as well as the history of medieval England and France. A more thorough discussion of marriage practices will be reviewed including the development of consanguineal restrictions by the Church. 


\section{Chapter Three: History of medieval Europe, England and France}

\section{Historical Background of medieval Europe}

With the collapse of the Roman Empire, beginning in the fourth century, smaller independent kingdoms were allowed to develop throughout the former empire. Multiple kingdoms developed out of the Germanic tribes that dominated central and western Europe (See Figure 3.1). In order to understand this development, it is necessary to view it through the lens of feudalism and the corresponding manoralism. This system allowed for the creation of a distinct ruling class and a defined hierarchy with the majority of the population tied to land controlled by others.

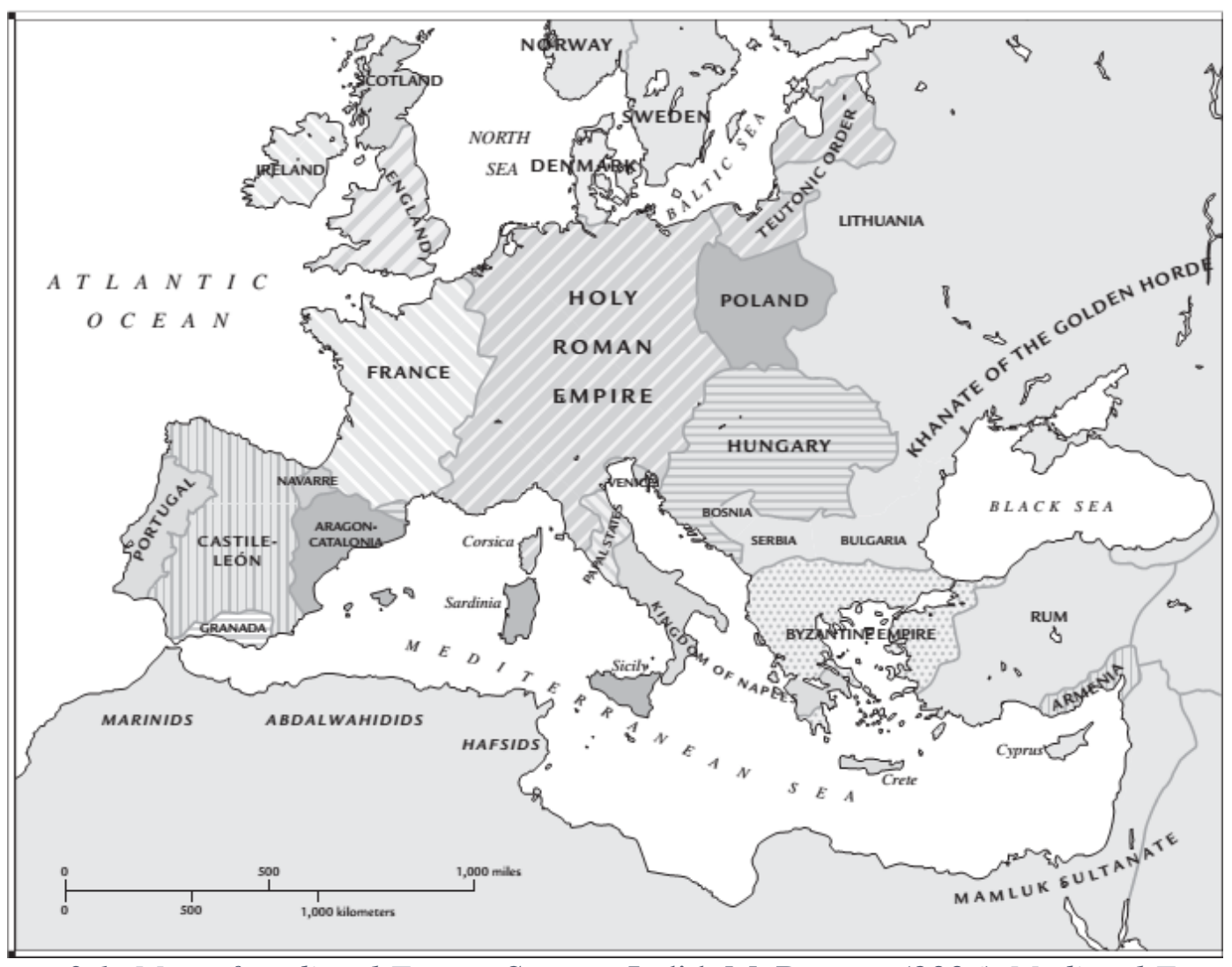

Figure 3.1: Map of medieval Europe Source: Judith M. Bennett (2006) Medieval Europe: A Short History. (McGraw Hill, 2006), http://www.medievaleuropeonline.com/maps/61.pdf. 
The origins of feudalism can be traced to the Viking invasions beginning in 793 AD. Invasions were nothing new to Germanic Europe, however these invaders represented something different. The Vikings were able to travel further distances, especially inland, attacked settlements that thought they were safe, and did not respect religious houses of worship. As a result, the people of Europe began to look to their leaders for protection. This initiated the system of feudalism and manoralism where individuals were willing to surrender their freedom in exchange for their protection. Feudal lords amassed groups of well-trained individuals (knights) who then became their personal armies. These knights would provide protection to the people who lived on the manor that was owned by the feudal lord. The knights became vassals of the feudal lord. At the same time, the feudal lords became vassals of the king who rewarded the lords for their loyalty through land grants and titles. In exchange, the king could call on the lords for the use of their armies. This system allowed for individuals to gain power very quickly and as a result, portions of Europe became more centralized. This was seen in England as a result of the Scandinavian invasions. In France, portions were more centralized, especially under the Capetians, but large portions remained decentralized (Bennett 2006).

\section{Historical background of medieval England}

In England, Alfred the Great, King of the West Saxons, was able to defeat the Vikings in 878 which secured his position as the main ruler (House of Wessex) of England and established the Danelaw which created peace between the Anglo-Saxons and the Vikings by formally outlining each territory. His successors would oversee the unification of large portions of England (See Figure 3.2). In 1013, Sweyn Forkbeard, a 
Dane from the House of Denmark, invaded England and replaced the Wessex king Æthelred the Unready. This began a period of uncertainty as the House of Wessex competed with the House of Denmark over control of England.

The House of Wessex was restored in 1014, only to be defeated again in 1016. Edmund Ironside (son of Æthelred the Unready) signed a treaty with Cnut the Great (son of Sweyn Forkbeard) that gave Cnut control over all of England with the exception of Wessex. Edmund Ironside died within a month of the treaty so Cnut was able to gain control over all of England. Cnut and his descendants would rule England until 1042. In 1042, Edward the Confessor, son of Æthelred the Unready, was able to restore the House of Wessex to power. However, Edward died in 1066 without an heir and so the House of Wessex's claim on the throne ended (Bennett 2006). 


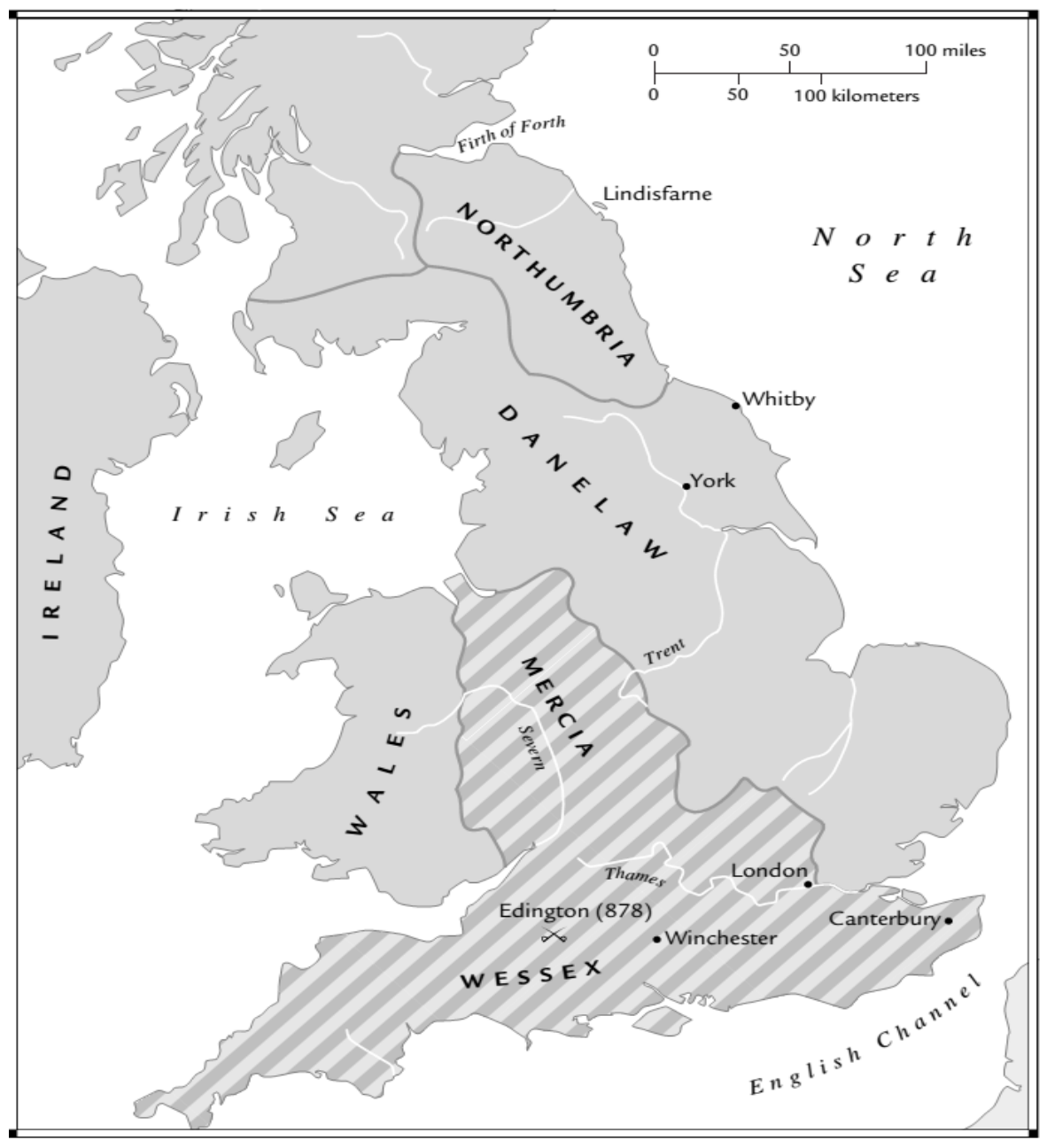

Figure 3.2: England under King Alfred Source: Judith M. Bennett (2006) Medieval Europe: A Short History. (McGraw Hill, 2006),

http://www.medievaleuropeonline.com/maps/5-3.pdf

In January 1066, Harold Godwinson established the House of Godwin and claimed the throne. At the same time, Harald Hardrada, the King of Norway, also lay claim to the English throne, as did William of Normandy. Each man claimed to be the heir of Edward the Confessor. Both Harald Hardrada and William of Normandy (the Conqueror) invaded England in October 1066. The King of Norway was defeated by Godwinson, but Godwinson was not successful in defeating the Normans. At the Battle of Hastings on October 14, 1066, Harold Godwinson was killed and William of 
Normandy became the next king of England on December 25. This established the House of Normandy that remained in power for the next seventy years (Bennett 2006).

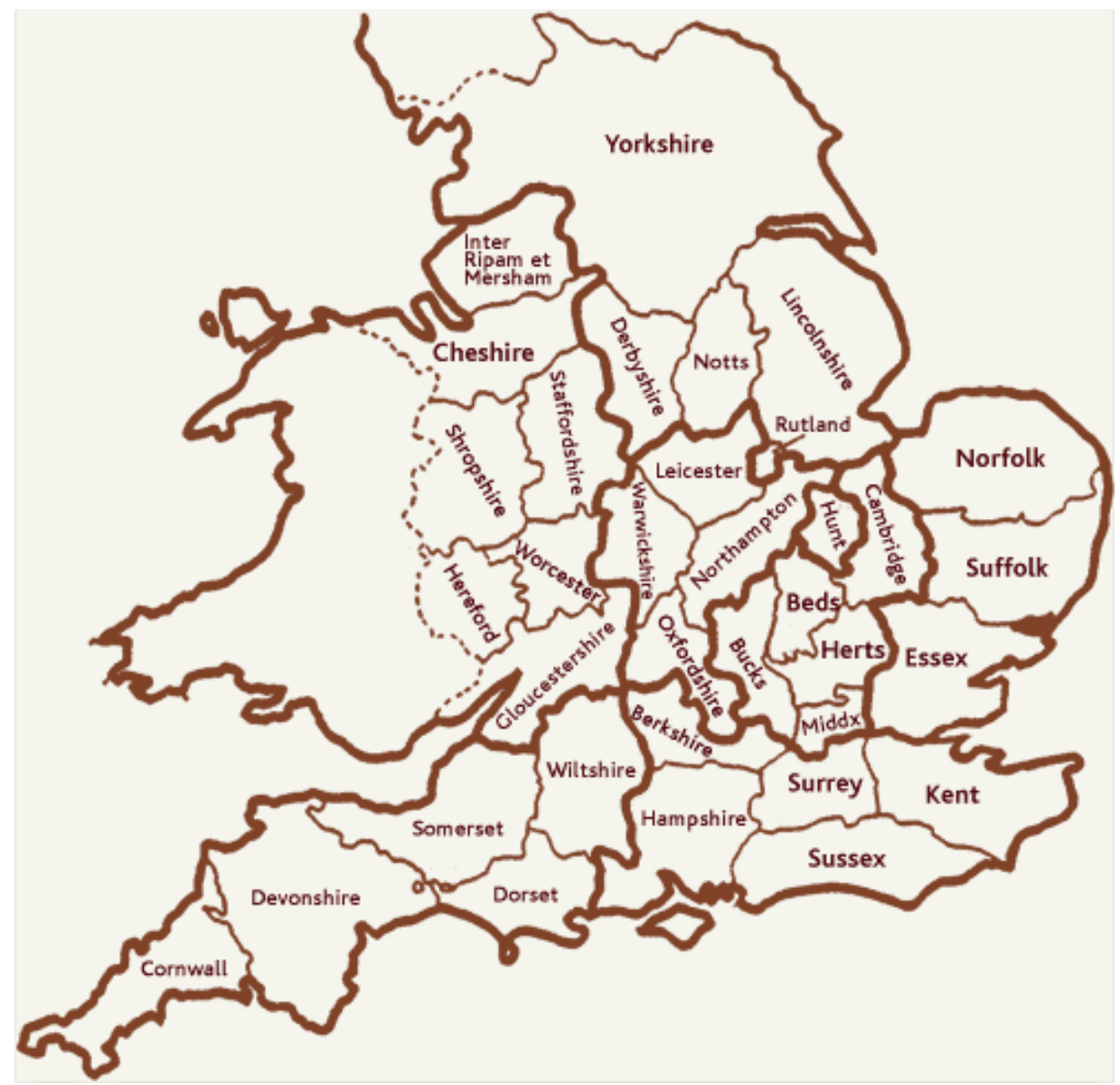

Figure 3.3 Map of medieval England

Source: familysearch.org/wiki/en/Domesday_Book/media/Field:Domesday_Book__Counties_of_England_-_1086.png.

\section{Historical background of medieval France}

Unification in France took a similar path with the establishment of the Frankish kingdom by Clovis (466-511) and the Merovingian Dynasty. This family would rule for the next two hundred years. Clovis would be instrumental in establishing Salic Law which laid the groundwork for the legal system throughout Europe. After Clovis' death, 
his kingdom was divided amongst all of his sons through agnatic succession (Bennett 2006).

The solidification of France continued under Charlemagne and the Carolingian Dynasty. In December 800, Charlemagne was crowned Emperor of the Romans in the West, the first to be recognized since 476 (Bennett 2006). During his reign, he expanded the territory held by the Frankish kingdom to include large portions of west and central Europe. In order to maintain control over such a vast territory, he divided the kingdom into multiple counties over which he assigned a count who represented a link between the local and the centralized government. These counts would create the groundwork for the landed aristocracy that dominated the system of feudalism.

Upon Charlemagne's death in 814 his son Louis the Pious succeeded him as the sole ruler of the Carolingian Empire. This was a position that he would eventually come to share with his three sons. Civil wars plagued his reign and would continue even after his death. The conflict was caused by Louis' attempt to impose primogeniture. This was vastly different from the Frankish tradition of partible inheritance. In 843 the Treaty of Verdun was signed that divided the Carolingian Empire into three separate kingdoms. These kingdoms were the predecessors to the medieval territories of France, Germany, and the county of Lotharingia that would be contested among France, Germany, and Italy sporadically until the twentieth century (Bennett 2006). The Frankish kingdom would begin to regain some of its grandeur under the leadership of the Capetians beginning with Hugh Capet (r. 987-996) the founder of the House of Capet. The Capetian kings would rule the Frankish kingdom for the next 340 years (See Figure 3.4). 


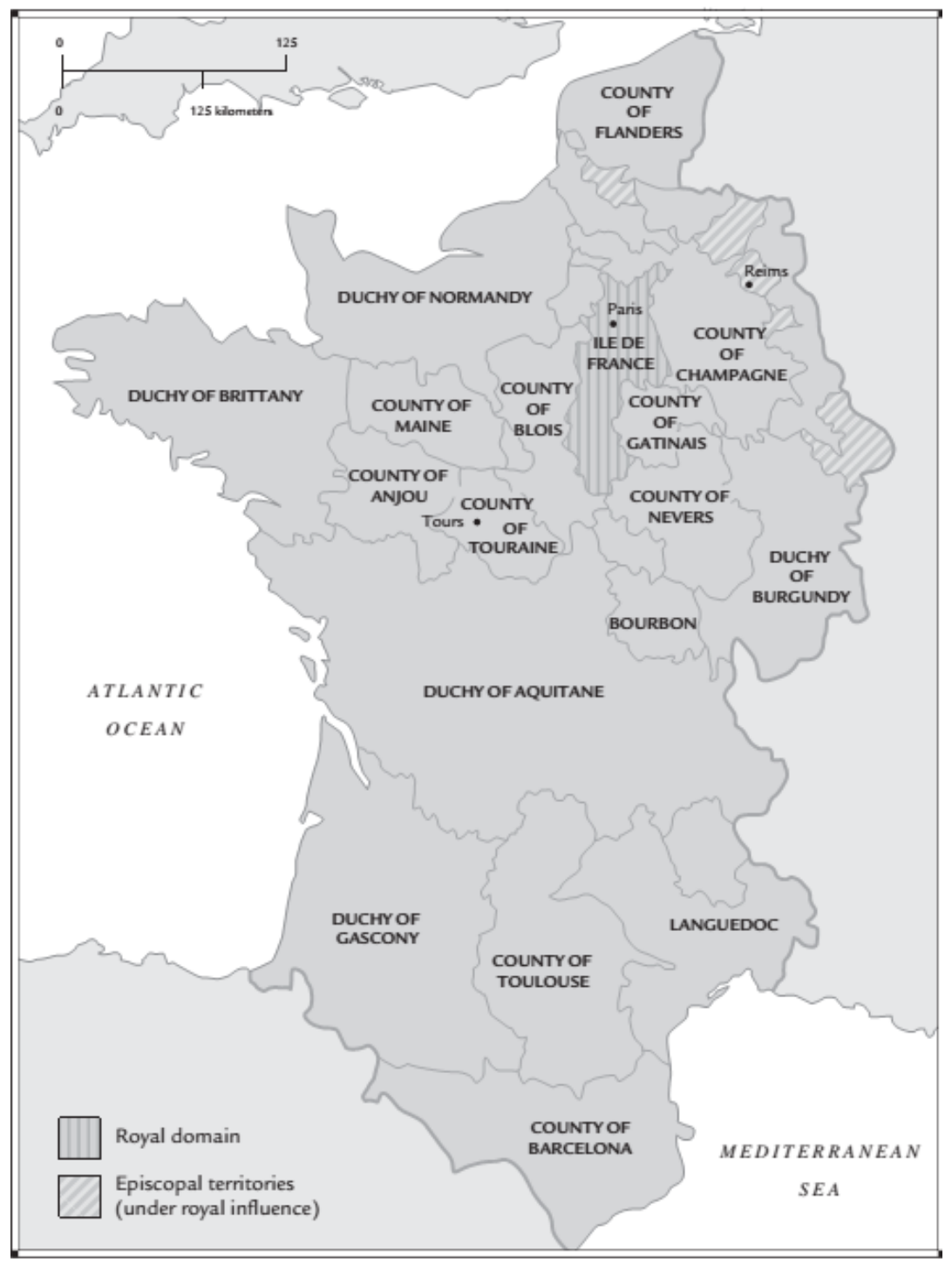

Figure 3.4: Capetian France 1000 AD

Source: Judith M. Bennett (2006) Medieval Europe: A Short History. (McGraw Hill, 2006), http://www.medievaleuropeonline.com/maps/5-4.pdf

Family relations in medieval Europe

Brundage (1987) argued that broader kin groups in the European kinship structure were of extreme importance after the collapse of the Roman Empire. An extended kinship network was prominent in Germanic society both before and after the invasions of the fourth century. Members of a kinship network were responsible for fulfilling 
obligations and protecting the entire network, not just close kin. This obligation extended to reciprocal revenge which required retaliation on whoever was responsible for inflecting damage to a member of the kinship network.

According to Flandrin (1979) there are three fundamentally different entities within the context of an extended family: the lineage, the house spirit, and the lineal spirit. The lineage refers to the patriarchal family within a familial house. In the tenth and eleventh centuries, the 'lignage' was deemed more significant than the 'house.' This difference was due to the fact that the lignage represented all of the individuals who were descended from, or claimed descent from, a common ancestor. The lignage could be recognized from either the male or the female line (Flandrin 1979). The lignage was clanlike in its structure. Its basic function was to protect its members. Familial security was especially important in the tenth and eleventh centuries when royal authority had declined. As royal power began to reemerge the significance of the lignage began to decline and was replaced by the lineage and respective houses.

In Normandy lineal inheritance applied to inherited property only and not to property that had been acquired by subsequent generations. The lineal property was transferred via specific rules, paterna paternis and materna maternis meaning that only lineage members of the father's side and the mother's side respectively had any rights over the inherited property (Livingston 2010). See discussion on primogeniture under Marriage in France below.

The stem family was situated in one household, that of the heir and his heir. The father, upon his death, transmitted the status of heir to his eldest son. During the father's lifetime however, he would invest in his heir by bestowing titles and knowledge relating 
to the familial estate and overseeing the arrangement of his marriage. Younger sons and daughters would leave their natal household upon marriage as they wished. They would be given an income from the revenue of the stem family and/or a dowry, but this rarely came from the capital of the landed property which would pass to the heir in its entirety. The heir was thus tied to the land and the house of the stem family while younger brothers and sisters had at least in theory a modicum of freedom (Flandrin 1979).

\section{Marriage in medieval Europe}

The purpose of marriage in Europe was to protect the patrimony. Marriage linked two family lineages or blood lines together. It also ensured that there was only one heir, the eldest born son, who would succeed to and maintain the continuity of the patrimony (Lucas 1983). Duby (1983, p. 18) proposed that through the institution of marriage and the rules governing marriage human societies control their future and perpetuate their own structure. As a result, the rites of marriage provide social stability through 1) the orderly distribution of women among men; 2) the regulation of competition among men over women and 3) the regulation of procreation. Marriage also adds another form of affiliation for offspring. By designating a father, children have another social link outside of the obvious one provided by their mother. This system also distinguishes a legal union from other types of unions and for the purpose of inheritance clearly signifies the heir and provides them with a name, rights, kinship, and ancestry. The transmission of wealth from one generation to the next was regulated by marriage.

Marriage in Europe was regulated by three traditions: Judeo-Christian, Roman and Germanic. In the Judeo-Christian tradition, marriage and reproduction were expected, divorce was permitted and fornication was tolerated. Adultery was not 
permitted especially among women however, concubinage was acceptable (McCarthy 2004).

In the Roman tradition, both legitimate marriage and concubinage were accepted and recognized. Offspring from both types of relationships were acknowledged by law. Those born as the result of a non-marital relationship were divided into two categories: naturalis (natural) and spurius (spurious). Natural births were associated with children born from a recognized concubinage relationship. The children may have been recognized by their father, and were able to inherit familial wealth, but there were limitations on this in order to protect the rights of their legitimate half-siblings. Spurious births were associated with children born from clandestine relationships (mother was a slave, a prostitute, father was unknown, or incestuous relationships) (McCarthy 2004).

Roman marriages were monogamous, but extramarital affairs were also common. Affairs were divided into two categories, 'stuprum' fornication, and 'adulterium' adultery with each category having different levels of acceptance and/or punishment. Fornication between unmarried free women and men was punishable as was adultery between a married woman and a man who was not her husband. However, a relationship between an upper class man and a lower class woman was overlooked (McCarthy 2004). Roman law allowed concubinage as an acceptable alternative to marriage. Divorce was also permitted under certain circumstances as was remarriage.

The key concepts of Roman marriage were conubium (the ability to take a wife) and consent. If both of these elements were present and there were no legal restrictions that prevented the marriage it was considered legal. Roman girls could marry at the age of twelve and boys could marry at the age of puberty. Betrothals could take place at much 
younger ages, as young as seven in some cases (Evans-Grubbs 2007). This practice would continue in the Germanic tradition as well as in medieval Europe.

The Germanic peoples' idea of marriage was much more fluid with three acceptable types of marriage: Kaufehe, Raubehe, and Friedelehe. A Kaufehe marriage was an arranged marriage which was orchestrated by the parents of the bride and groom. A Raubehe marriage was a marriage by capture. Friedelehe marriage was thought of as a quasi-marriage that was less formal and more easily dissoluble than the other types (Brundage 1987). Germanic law codes were less likely to distinguish between legitimate and illegitimate children. Children born from any of the above mentioned marriages were eligible to inherit from their fathers (including the throne) although children of a quasimarriage were usurped as heir if a child was born to a Kaufehe marriage.

As in the Judeo-Christian, Roman, and Germanic traditions, under the Christian tradition, marriage was the result of a series of complex negotiations that involved the exchange of property and the accumulation of wealth. The family was the primary participant, but marriage negotiations could also include the king. In Henry I's (king of England) coronation charter (1100) addressed the issue of a direct vassal of the king bestowing his own relatives in marriage. If one of Henry's barons died and left an unmarried daughter as his heir, she could only be given in marriage by the king (Ward 1995). Specifically the charter addressed the grievances of the barons who were concerned over the treatment of widows and children who were seen as being sold off to the highest bidder in marriage negotiations. The following is an excerpt from the charter:

And if any of my barons or my other vassals wishes to bestow in marriage his daughter or his sister or his niece or any [other] female relative he shall consult me on the matter, but I shall not take anything from him in return for my permission, nor shall I forbid him to bestow her in marriage, unless he desires to 
marry her to an enemy of mine. And if, on the death of a baron or any other vassal of mine, his daughter is left as heiress, I shall bestow her in marriage, with the consent of my barons, along with her land. And if, on the death of her husband, a wife is left and has no children, she shall have her marriage settlement and dowry, and I shall not bestow her in marriage except in accordance with her wishes. But if the wife is left with children, she shall have her marriage settlement and dowry as long as she observes continence, and I shall not bestow her in marriage expect in accordance with her wishes. And the guardian of the land and children shall be either the wife or some other relative who has a better right. And I enjoin upon my barons to act with like moderation towards the sons and daughters and the wives of their vassals (Robertson 1925).

If the permission of the king was not sought prior to a marriage there could be severe consequences. For example, in the following excerpt, the king's permission was not sought and as a result, the parties involved found themselves at odds with the king. After offering to pay the king, essentially a fine, the marriage was accepted, and the couple were received by the king.

Around the same time, the king's anger was again kindled against the earl of Kent, Hubert de Burgh, because Richard, earl of Gloucester, still a boy in the king's custody was joined in marriage to Margaret, Earl Hubert's daughter, without the king's permission or sanction. For the king had intended, it was said, to unite in marriage the same youth, the earl of Gloucester, along with all his lands and honors, with a certain relative of William, bishop-elect of Valencia, a native of Provence. Finally, however, with the intercession of a great many people, and because Earl Hubert declared that he had not known about this nor had it been arranged by him, and on his promising, a sum of money to the king, the king's indignation subsided (Murray 2001).

The necessity of securing an advantageous alliance influenced mate choice. From the male perspective this took the form of a wealthy heiress. This was particularly clear in the marriage contract, where the concern over money and land were of utmost importance. The marriage contract would specify the property arrangements between the families. It was drawn up by the fathers (or male relatives) of the bride and groom. The bride's father was required to provide her with a maritagium, a gift of land. This gift was 
intended to provide the couple with a means of supporting themselves and their future family. This land would stay within the family across multiple generations. According to the Statute of Westminster (1285), the land would pass to the heirs of the marriage and four subsequent generations. During his lifetime, the donor, (the bride's father) would be responsible for any feudal services associated with that land. This allowed the daughter and her family to hold the land freely. In the event that the daughter failed to produce an heir, the land would revert back to her father.

Both men and women were expected to marry monogamously and produce heirs. However, while males were expected to marry monogamously, they could also participate in concubinage, a form of polygyny, which was classified as a personal union with little regulation. In this sense males married monogamously but mated polygynously. As a result, it was not uncommon for males to have large numbers of offspring, both legitimate and illegitimate. Children born to a marriage were legal heirs and were the only offspring eligible to inherit familial resources. Children born to a mistress or concubine were not eligible to inherit their father's wealth. In some cases these children were provided for by their father's through lesser titles, positions in the military, or high church offices (Flandrin 1979). Among the population in this sample, monogamy was the only accepted form of marriage.

\section{Church influence on marriage}

The Christian perspective on marriage was much more restrictive than the JudeoChristian, Roman, or Germanic traditions. Sexual relations were restricted to marriage. Despite this restriction, extra-marital relationships and illegitimate children were a regular part of European society. Christian doctrine concerning illegitimate offspring was 
much more rigid than either Roman or Germanic law, with the majority of illegitimate children being barred from their father's inheritance.

In contrast, under the Christian tradition, the Church prohibited all relationships outside of marriage. However, the Church did adopt two aspects of Roman marriage law: the idea of consent and maritalis affection, or marital affection. In order for a marriage to be considered valid, both parties had to give their consent. There are several examples of marriages in both medieval England and France being annulled because one or both parties claimed they did not give consent. This was especially true for marriages that were arranged when the parties were underage (McCarthy 2004).

In the twelfth century, the definition of consent became the basis for Pope Alexander III's marriage doctrine which stated two methods for expressing the consent to a marriage, present consent and future consent. Present consent marriages occurred when words of consent were exchanged in the present. Future consent marriages occurred when consent was given for marriage in the future with the idea that the marriage would be completed later (McCarthy 2004).

Despite the church's attempt to create a uniform ethic of marriage, differences still existed throughout Europe. For example, Ireland and Iceland had much different marriage traditions, especially in the indissoluble nature of marriage. Marriage in Italy followed Canon Law, but had different economic and social expectations of the parties involved. Marriage in England and France remained fairly consistent with Canon Law as well as the associated social and economic expectations. 


\section{Church influence on consanguineal marriage}

Marriage in medieval Europe was impacted by a number of factors. Political connections, social standing, and wealth were of utmost importance, but of equal importance were consanguinity and familial relatedness in determining potential marriage partners. Due to the desire to maintain and increase wealth and social standing, marriage was principally endogamous with partners chosen from the highest level of the aristocracy. This resulted in a closed population of individuals who were related on multiple levels of kinship.

According to Flandrin (1979), kinship fell into five categories, each with marriage restrictions associated. The simplest form of this was natural kinship, i.e. consanguineal kin. Legal kinship was the next category which included individuals who had been adopted into a family unit thereby creating a kin link between the adopted individual and the entire family of the foster father. The third category referred to legitimate affinity. Individuals were kin by marriage and a connection existed between the spouses and their families. Another category of kinship was illegitimate affinity which resulted from clandestine relationships. The last category of kinship was especially important to the Church and that was spiritual kinship. A familial connection was thought to exist between a baptized child, his/her parents, the godparents, and the godparents' close relatives. This also extended to the confessor and their penitent as well as the catechist and the catechumen.

The degrees of consanguinity varied based on the Roman, Germanic, and Christian computation. The Roman system of consanguineal computation was based on generations. So, brothers and sisters were related in the second degree and aunt/uncles 
and nieces/nephews were related by the third degree. In the Germanic system, individuals were restricted from marrying anyone with whom they shared a common ancestor in the previous seven generations.

According to Goody (1983) "in the direct line, the degrees is equal to the number of generations or persons, not counting the common ancestor. In the equal collateral line, the number of degrees is equal to the number of generations or persons on one side of the line, not counting the common ancestor. In the unequal collateral line the number of degrees is equal to the number of generations or persons, not counting the common ancestor, on the longer side, although during much of the medieval era this determination was made according to the shorter side."

Marriage was considered within the realm of the lay courts. As a result, initially the Church did not exert legal control over marriages or the selection of marriage partners. However, that does not mean that the Church did not attempt to exert some control over close marriage. For example, as early as the Synod of Epaon in 517 marriage was prohibited between first cousins. Marriages of this type that had occurred prior to 517 were considered legal. The Trullo Synod of 692 prohibited incestuous unions and punished offenders with seven years of excommunication. In 756/758 the Council of Compiègne was held and marriages within the fourth degree of consanguinity were dissolved. Closer marriages such as those within the third degree were nullified by the Church.

An Anglo-Saxon papal council called in 786 stated that the heir to a throne must be legitimate (born from a legitimate marriage); otherwise he was not worthy for the Lord to anoint him as king (Wertheimer 2006). The official clerical stance on incestuous 
(consanguineous) marriages, prohibited marriages between couples too closely related by blood as well as through spiritual and legal relationships. As a result, the Church had a much more complex view of kinship and acceptable marriage partners.

The Church's influence on marriage began to shift in the eighth century. Between the eighth and twelfth centuries, members of the clergy began to emphasize the sanctity of marriage. Rules restricting consanguineal marriage and incest emerged. By the twelfth century, canon law exerted a greater amount of control over lay marriages. Marriages between kin were condemned as incestuous by canon law. Church officials used chapter 18 of Leviticus as the basis to restrict close kin marriage. Relationships were prohibited between men and their consanguineous relatives (specifically their mother, daughters, sisters, half-sisters, granddaughters, cousins, or aunts). Restrictions were also extended to include affinal kin. Men were prohibited from relationships with their mother-in-law, daughter-in-law, stepmother, stepdaughter, sister-in-law, uncle's wife, and grandmotherin-law.

In the ninth century, Pope Nicholas I declared that all couples who had married with the restricted degrees of consanguinity would have their marriages dissolved (Masters 1994; Reynolds and Witte 2007). They were also to be shunned by the Church and society until they had completed penance. He created a penance scale which was determined by the degree of kinship. The closer the degree, the greater penance required from the couple. Incest with a cousin, an aunt, a grandchild, or a grandparent required penance for ten years. Both offenders were banned from the Church and had to live on bread, water, and salt every day except Sundays and feast days for a full year. In the second year of penance, the individuals could attend church and they were allowed to eat 
meat and drink wine except on Sunday and holy days. In the remaining years of the penance, three fasts were to be observed each year and the offenders were not allowed to contract a new marriage. If the incest involved a relationship with the mother, sister, or daughter, the penalties and penance were more severe. This included a seven year fast of bread and water and twenty-one years of three annual fasts (Masters 1994).

Despite these restrictions marriages between consanguineal and/or affinal kin occurred. However, a special papal dispensation was required in order for these types of marriages to occur. For example, within the sample population, Eleanor of Aquitaine and her first husband, Louis VII, were second cousins twice over. Their two daughters, Marie and Alix, married the brothers (their step-uncles) of Louis VII's third wife, Adela. Isabel de Ferrers, the granddaughter of William Marshal, married as her second husband Reginald II de Mohun who was her elder sister Joan's father-in-law. Each of these marriages required the permission of the pope and a monetary payment. Marriages of these type were a cause for concern because at some point in the future, one or both of the parties could ask to have the marriage annulled based on the grounds of consanguinity. 


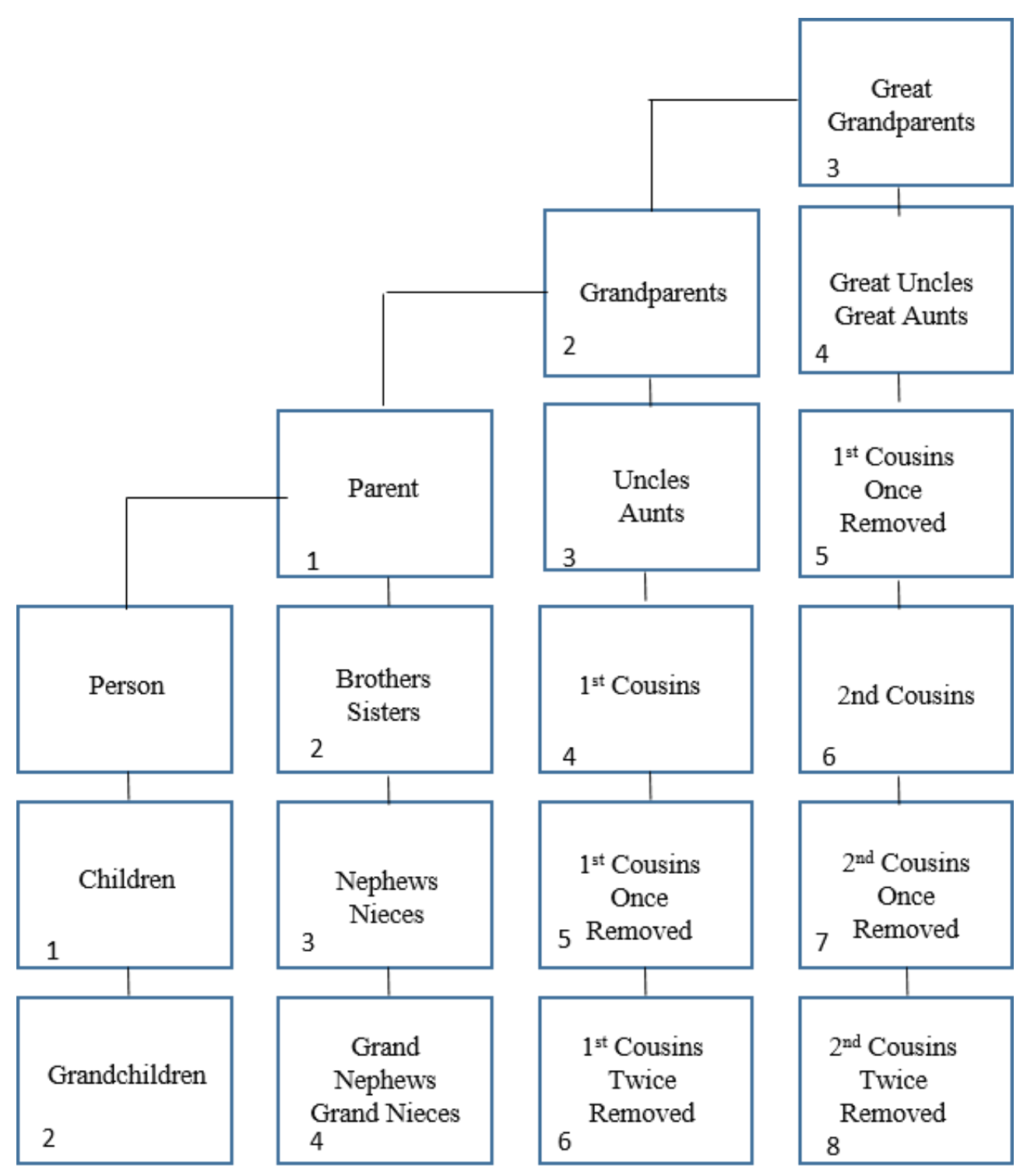

Figure 3.6 Degrees of Consanguinity. Adapted from 'Table of Consanguinity' from fink.org.uk

In order to determine the degree of consanguinity, canonical writers used several components, the first of which was the stock or common ancestor. Once the common ancestor was identified, the line of descent from that individual had to be established. The line of descent was then divided into two categories, direct and collateral. The direct line of descent referred to lineal consanguinity and included individuals who were directly descended from each other such as a parent and child. The collateral line of descent 
included individuals who also had a common ancestor, but were not directly descended from each other such as an uncle and niece or aunt and nephew). Finally, the degree of relatedness, the distance between individuals who are related in the same line, had to be determined.

Consanguineal kinship ties were important, but so too were affinal kinship ties. The strength of these ties can be seen in legislation passed in France to prevent certain families from controlling the royal court and the legal system. In 1669 Louis XIV stipulated the degrees of kinship that were incompatible with the holding of legal offices. Fathers, sons, brothers, uncles and nephews were restricted from holding certain offices. This restriction also extended to affinal kin to the second degree, including fathers-inlaw, and sons-in-law (Flandrin, 1979).

The Church first prohibited marriage within the Roman computation of the fourth degree of consanguinity which was up to and including a second cousin. Between the tenth and twelfth centuries, this had been pushed back to the seventh degree, which was the equivalent of the Roman fourteenth degree of consanguinity. This in combination with the marriage restrictions on spiritual kinship and legitimate affinity meant that there were no eligible legitimate partners. As a result, in 1215 at the Fourth Lateran Council, the Church lightened the restrictions to the fourth degree (first cousin) for consanguineal kin and the second degree for affinal kin.

While the Church had attempted to regulate marriage since the eighth century, under the Fourth Lateran Council (1215) Pope Innocent III formally restricted marriage to the fourth degree of consanguinity. This meant that individuals were prohibited from marrying someone with whom they had a common ancestor within four generations. 
These restrictions also extended to affinal kin. Marriage was prohibited between

individuals whose ancestors had married in the previous four generations (McCarthy

2004). The following is an excerpt from Innocent III's stance on consanguineal marriage.

All the prohibition of marriage in the three remotest degrees is repealed, we wish it to be strictly observed in others. Hence, following in the steps of our predecessors, we absolutely prohibit clandestine marriages, forbidding also any priest to be present at such. For which reason we extend the particular custom of certain countries to countries generally, decreeing that when marriages are to contracted they shall be published in the churches by the priests, a suitable period being fixed beforehand within which whoever wants and is able to may adduce a lawful impediment (Leyser, 1995).

\section{Marriage in England}

Marriage was important for the transfer of property both within and between families and as a result both secular and ecclesiastical law in England were impacted (McCarthy 2004). Secular marriage law was concerned with property transfers while ecclesiastical law had jurisdiction over the bonds of marriage. In the following marriage contract between Humphrey, Earl of Warwick and Ralph Thosney dated 1236, the ideas of consent (future consent), the transfer of property, dowry, and the importance of legitimacy can be seen.

This is the agreement made between Sir Humphrey, Earl of Warwick, of Hereford, on the one part, and Sir Ralph of Thosney, on the other, namely that the said Earl Humphrey has given in free marriage 40 pounds worth of land in the village of Newenton, in Wiltshire, to Roger, eldest and first born son of Sir Ralph of Thosney, with Alice his daughter. [It is agreed] that if the land in Newenton shall not suffice to produce 40 pounds, the said Earl Humphrey shall make it good to him from a suitable location in the same county, and if it should happen that the aforesaid Roger, son of Ralph Thosney should die before coming to a proper age for contracting [marriage], the said Earl Humphrey shall grant and concede the aforesaid 40 pounds in land to Ralph, son of the said Ralph of Thosney with the aforesaid Alice, daughter of Earl Humphrey, in free marriage. And if the said Alice shall die before the contracting of marriage, the younger daughters of the said Earl Humphrey born in legitimate marriage shall succeed in place of the said Alice in marriage together with the aforesaid land. And the said Humphrey shall 
hold the same 40 pounds worth of land in his hand until Roger or Ralph, sons of the said Ralph of Thosney, shall legitimately contract with the daughter of the said Earl Humphrey. And the said Ralph of Thosney has given and granted to Roger, his eldest son and heir, 40 pounds worth of land in Carleton and Helland in Cornwall to endow the said Alice, daughter of the said Earl Humphrey, in this manner, namely that if the said land in Carleton and Helland shall not suffice to produce 40 pounds, the aforesaid Ralph of Thosney shall make it good to him from a suitable location in the same county. And if it should happen that the said Roger should die before coming to a proper age for contracting [marriage], the said Ralph of Thosney has given and granted the said 40 pounds worth of land to Ralph, his younger son, to endow the aforesaid Alice to another younger daughter born legitimately to the said Earl Humphrey, if it should happen that the said Alice shall die before coming to proper age for contracting [marriage]. And the said Ralph of Thosney shall hold the said 40 pounds worth of land in his hand until said Roger or Ralph shall legitimately join together with the daughter of the said Earl Humphrey. And if it should happen that the said land in Cornwall is so held that it cannot be granted to endow the daughter of the said Earl Humphrey, 40 pounds worth of land in the manor of Tauton shall constitute the dower and be granted to the daughter of the said Earl Humphrey at the time she can lawfully contract [marriage]. And the said Earl Humphrey and Ralph of Thosney are agreed that when the son of the said Ralph of Thosney and the daughter of the said Earl Humphrey shall come to an age when they may lawfully contract [marriage], they shall contract it at once, and that immediately after the contract of marriage the said Earl Humphrey and Ralph of Thosney shall put the son of the said Ralph and the daughter of the said Earl Humphrey in lawful seisin of the aforesaid lands. Moreover, for this agreement and grant, the said Earl Humphrey has given 200 marks to the said Ralph of Thosney paid in hand. Each of them has sworn to keep this agreement faithfully and without fraud. And for greater security, each has set his seal to the present charter in the manner of a chirograph. These witnesses: Sir Roger de Lacy, Earl of Lincoln, Sir John Biset, Sirs John son of Galfrid, Emory of Saint Amand, Egidius of Clifford, John of Saint Laud, William of Mown, John of Cheveron, and many others (Helmholz 2007).

The Papacy under Innocent III established formal steps, outlined in Canon 51 of the Fourth Lateran Council, for the arrangement and completion of a marriage. The first step was a formal betrothal. A betrothal was a financial settlement that had to be agreed upon by both the bride's and groom's families. A bride was expected to bring a dowry to the marriage. This dowry represented the bride's share of her family's wealth. Once the marriage settlement was agreed upon, a formal betrothal ceremony would be held in front 
of witnesses, which secured the future marriage. Many betrothals took place when the parties were very young. A betrothal could take place any time after a child had reached seven years of age. The actual marriage would not occur until the bride was at least twelve years old and the groom was at least fourteen (Leyser 1995).

In order for the actual marriage to occur, the banns (formal announcement of the marriage) had to be read in the church three times. This allowed for any objections to the marriage to be heard. If there were no objections, the marriage could proceed. Marriages could not however, occur during the weeks of Advent and Lent. The actual wedding occurred at the church doors, where the couple would meet, the groom would make a formal announcement of the dower he was providing to the bride upon marriage and give her a ring that had been blessed by the local priest. The couple would then proceed inside the church where a mass would be held and a blessing would be said over the couple. A wedding feast would follow where both the father of the bride and the groom were expected to provide lavish festivities (Leyser 1995).

\section{Marriage in France}

In Carolingian France, marriage was considered a sacred institution. Its purpose was to ensure the passage of valor and honor to the next generation. As such, it was the responsibility of the eldest son to marry and produce a legitimate son who would continue the bloodline and the honor of the family lineage. In order for this transmission to occur, the value of marriage had to be preserved, which meant that a marriage was relegated to a single spouse who was not related within the seventh degree of consanguinity. Hugh Capet, King of the Franks (987-996), illustrated the difficulty in 
finding a wife when he explained "we cannot find a wife of equal rank because of the affinity between us and the neighboring king" (Duby, 1983).

By the twelfth century, the perception of marriage had evolved. Georges Duby defined two models of medieval marriage in twelfth century France, ecclesiastical and aristocratic (1983). Ecclesiastical marriage was based on exogamy and consent. The aristocratic model of marriage was based on endogamy and arranged marriages. These two models had very different interpretations on the structure and function of marriage. The ecclesiastical model of marriage was much more regulatory than the aristocratic model of marriage. The collision of the two would lead to a new interpretation of marriage by the end of the twelfth century. As the Church grew in power, so did its regulatory power over marriage.

The ecclesiastical model of marriage, under Pope Gregory VII, originated as a means of regulating marriage among the clergy According to Brooke (1989), marriage began with the consent of the two parties. The actual consummation of the marriage, what would later be viewed as making the marriage official, was secondary. Duby (1978) cites that if one had to marry at all, it was better to marry than to engage in carnal activity outside of marriage and burn in Hell.

The ecclesiastical model discouraged concubinage, although this was one of the more tolerant aspects of the model. A man should not have a mistress and he especially should not have a wife and mistress. When the aristocracy did not abide by this regulation, the Church redefined concubinage. It was defined it as a clandestine form of marriage. The result was a society in which a man could not have a wife and a mistress and remain in good standing with the Church. If he had a wife and a mistress, by 
definition he had two wives and he was guilty of bigamy. Bigamy carried both social and religious consequences (often a fine and exclusion from communion).

Another part of the ecclesiastical model was its prohibition on endogamous marriage and enforcement of exogamous marriage. People were prohibited from marrying within certain degrees of familial relatedness. This prohibition was intended to prevent incest among close kin. Originally marriages were restricted to the seventh degree of consanguinity although this would eventually be reduced to the fourth degree. There were also exceptions to this; with special permission from the Church individuals were occasionally allowed to marry within the degrees of consanguinity.

While these regulations were intended to strengthen the ties of marriage, the prohibition on endogamous marriage and the incest taboo actually provided a marriage loophole for the aristocracy. In part to combat this, by the end of the twelfth century, marriage had become a sacrament, making divorce virtually impossible (McCarthy 2004). Only under specific circumstances was divorce allowed. Under the ecclesiastical model, incest became the only means by which to obtain a divorce. Members of the aristocracy who had received papal dispensation to marry within the restricted degrees of consanguinity could later say that they needed to divorce because they were too closely related. This loophole was especially important in elite marriages where an heir had not been produced. For example, Eleanor of Aquitaine after meeting a young Henry (future Henry II) decided that her marriage to her husband Louis VII, the King of France was invalid because they were too closely related based on the Church restrictions on consanguinity. The marriage was annulled and she later married Henry. Eleanor and 
Louis were distant cousins, and in addition to the fact that they were incompatible personally, Eleanor had only produced two daughters and no male heir.

The aristocratic or lay model of marriage was also designed to regulate sexual behavior, but not as a means of controlling sin, but rather as a means of controlling inheritance. Marriage was intended to secure the family position in society and to provide heirs. In this vein, the aristocratic model encouraged endogamy rather than exogamy. The elite wanted to marry within their own social class to prevent the dispersal of their wealth and status. The ecclesiastical model's prohibition on endogamous marriages was especially problematic for the elite.

Elite men were not to have a mistress, although, under the aristocratic model, there was no punishment for adultery. Nor were there any restrictions on divorce. A man could divorce his wife at will. In response to this, the Church made concubinage a form of marriage, so a man who committed adultery would have been guilty of bigamy. To prevent easy divorces, the Church also made marriage a sacrament. As a result, men could not divorce their wives at will; rather they had to prove that their marriage was incestuous.

One of the ways that Duby (1978) argues the elite in France dealt with the prohibitions on marriage under the ecclesiastical model was to limit who could actually get married. In France only first born sons (the elders) were allowed to marry while their younger brothers (the youth) were not. The youth were destined for career in the military or the Church unless their older brother died and then they would be able to marry. By limiting who could marry, this opened up the availability of marriage partner's within the 
acceptable lines of consanguinity. This pattern of marriage strengthened the use of primogeniture in France, a practice that would eventually spread to other parts of Europe.

Eventually, there were so many 'youth' that it became necessary to allow them to marry. As the youth married, they began to establish satellite or cadet branches of their families. These cadet branches also provided potential marriage partners. According to Duby, the only reason it was possible for these cadet branches to marry was because of an increase in the wealth of the family.

The confrontation between the ecclesiastical model and aristocratic model of marriage led to a combined semi-regulated model for marriage. The elite continued to marry endogamously, but it was within the ecclesiastical model's degrees of consanguinity (except for Spain which continued to participate in cousin and uncle niece marriage until the eighteenth century). The purpose of marriage was still to procreate; to produce heirs to secure the family wealth and status. The prohibition on concubinage was lifted as was the bigamy charge and divorces were more difficult to obtain, except in cases of incest. This combined model would continue to influence the marriage pattern throughout the medieval and early modern period.

\section{Inheritance patterns in Europe}

Stratified societies, such as Medieval Europe, with heritable wealth will adopt inheritance patterns which allow for the transmission of wealth to specific heirs. However, not all European countries had the same type of inheritance pattern. Instead succession took three different forms and could vary depending on country. The first method of succession was election and or appointment. The election of rulers was common in the Nordic countries, Anglo-Saxon England, Capetian France, and the Holy 
Roman Empire as well as in Scotland and Russia. The election of a leader avoided several problems such as the leader being forced to appoint an heir, which could prove problematic and even life threatening if the heir decided to eliminate their predecessor. This also avoided problems if an heir were to be appointed and then another successor was chosen, there could be competition between the two appointed heirs. This was the case in England in 1066 which ultimately led to the Norman invasion.

The second method of succession was through agnatic seniority. With this system the eldest surviving brother of the current ruler would inherit the throne. The throne passed from brother to brother until the last brother died and then the inheritance would revert back to the eldest son of the eldest son. The system would then start over passing the title from brother to brother. If there was a lack of male heirs (sons or nephews) the title would then pass to male cousins and their offspring. This type of succession was seen in several Slavic countries. Two of the largest families in this project (the Piast of Poland and Rurik of Kiev) used this method of inheritance. There were some benefits to this system because there was always an heir of mature age. This eliminated the need for a regent and decreased potential competition amongst heirs. At the same time however, this system was also problematic because at any given time there would be multiple related males of about the same age as potential heirs (Kokkonen and Sundell 2014).

The third method of succession was primogeniture. The most common form of primogeniture was agnatic. Under this system, the eldest son of the eldest son would inherit. This system ensured that there was only one potential heir at any given time and could potentially reduce inter-familial competition. It was this last type of inheritance that would eventually become popular as an inheritance pattern in both England and France. 
French inheritance laws were governed by Salic law which was first introduced by Clovis I (r. 481-511) founder of the Merovingian dynasty. Salic law was governed by four principles: cadency, lineality, legitimacy, and sex. Cadency required that heirs were considered in the order of their birth. The first born male was the preferred heir to the familial lands, although primogeniture was not the official inheritance policy. Lineality required that the eldest son inherit the paternal lands, title, and any position held by the father. This son would then be required to provide for his younger brothers. The principles of legitimacy and sex were especially important to guarantee the transfer of the patrimony to a legitimate heir (Flandrin 1979). The legitimacy portion of Salic law was often overlooked in feudal France as illegitimate births were common among upper class males who often had multiple concubines.

Primogeniture calls for inheritance by the eldest child, either male or female. Dickemann (1979) found that the aristocracy of Medieval Europe favored the inheritance pattern of primogeniture where eldest sons would inherit their father's land, titles, wealth, and social status. The law of primogeniture in medieval Europe therefore dictated that first-born sons would solely inherit the ancestral estate. Younger sons and daughters would also inherit property (wealth, lesser titles, commissions, and dowry respectively). In order to increase the size of the family holdings, offspring were expected to marry well.

This pattern first appeared in tenth century France among the Capetian kings. Prior to this inheritance was based on the father's preference where a younger favored son could inherit. Within the same system, only oldest sons were allowed to marry creating a situation where there could be an excess of cadet sons, those who may or may 
not inherit (Duby 1978). This also led to an increase in illegitimate offspring who under the inheritance pattern could inherit from their father albeit with certain restrictions. Illegitimate sons could not inherit family estates or principle titles, but they could inherit wealth and lower ranking titles. A much different pattern would emerge in England where all sons were allowed to marry, but only the eldest son was eligible to inherit the familial estate. Here primogeniture was the only accepted inheritance pattern among the titled elite with few exceptions.

By the eleventh century, Salic law and the inheritance pattern of primogeniture were becoming more favorable as an inheritance pattern in both England and France. Primogeniture dictates that property be transferred to the eldest child, in this case a son. Due to this, parental investment shifted so that there was a preference for sons over daughters (Hartung 1976; Hrdy \& Judge 1993).

The practice of primogeniture limited the number of preferred offspring produced among the aristocracy of France and England. If too many children were produced, the inheritance may have become a point of strife with sons competing over access to resources. By shifting parental investment to specific children, however, the aristocracy of France and England were able to limit their legitimate offspring to maintain the wealth and status of the line in the lands of a few rather than many (Smith et al. 1987).

The ideal family size among European royalty was small with only two or three children surviving to adulthood. An heir and one to spare could be used to describe the ideal number of male children. Men wanted to have two sons, one to inherit from him and the other as a spare. This would ensure the succession of the line if something were to happen to the heir. Once the heir had reached the age of majority, usually around age 15, 
he was married with the understanding that it was his responsibility to produce an heir himself. Once an heir to the heir was born, the spare was disposed of either through the military or through a career in the church. Any more than two sons and there was a greater potential of conflict. There are examples of this in medieval history, for example King Henry II of England and his wife Eleanor of Aquitaine. They had four sons, Henry, Richard, and Geoffrey, and John who survived to adulthood. These sons with Eleanor's assistance rebelled against their father in a bid to assume the throne. The insurrection was put down, in large part with the assistance of Henry's illegitimate son Geoffrey Plantagenet. After the insurrection, Henry II never again trusted his legitimate sons, but Geoffrey would go on to become a trusted advisor (Hamilton 2010). Another example would be that of King Edward III of England and his wife Philippa of Hainault who produced thirteen children, seven of which were sons. This plethora of sons ultimately led to a dynastic struggle referred to as the Wars of the Roses. This conflict saw members of the royal family killing each other as they competed for the throne of England (Johnson and Johnson 1991; McCullough et. al 2006).

Inheritance for daughters took the form of marriage payments or dowry. Dowry, as a form of marital transfer, was characteristic of most ancient Mediterranean societies as well as the clans of Europe (Goody 1983). Under this system of transfer women would acquire wealth from both male and female relatives upon her marriage. The property being transferred leaves the bride's family and ultimately their control. The maintenance and security of this property could be one possible explanation for the adoption of endogamous marriages. Marriage within or between families reinforced family ties and prevented the loss of wealth. 
In medieval Europe, daughters of the propertied class were given a dowry at marriage. Dowries often took the form of land or property, but it may also have included jewelry, money, and other types of personal property. In some cases, a dowry may have included a title. In the second marriage of Eleanor of Aquitaine, her husband Henry II, King of England, became the Duke of Aquitaine because Eleanor was the heiress of the title and the duchy. Dowries were most often provided by the father of the bride, but the mother would also provide a dowry, perhaps even a part of her own dowry. The larger the dowry the more appealing a bride was in the marriage market. This was especially important as political alliances were based on these marriages.

The desire to have sons can also prove tricky when limited resources are at stake and may even in some cases decrease a parent's reproductive success. A reduction in reproductive success may occur when competition for the limited resources creates conflict within families. There are numerous examples throughout European history where rivalry over resources led to competition within families. The Norman invasion of 1066 was the result of a dynastic struggle. William of Normandy invaded England and made claim to the throne as the heir of Edward the Confessor. Harold II, another claimant to the throne, met William at the Battle of Hastings where Harold II was subsequently killed. Thus began the Norman period of medieval England.

The Anarchy was a second example of an interfamilial conflict. The Anarchy fought between England and France began in 1135 with the death of Henry I. Henry's only legitimate son, William had died in the White Ship disaster in 1120. In the wake of this tragedy and the loss of his only legitimate male heir, Henry attempted to secure the throne for his daughter Matilda. Upon Henry's death, his nephew Stephen of Blois, of 
France, seized the throne from Matilda. The conflict finally ended in 1153 when Stephen named Matilda's son Henry as his heir. This Henry would become King Henry II, the first of the Angevin kings.

Norway also experienced a civil war which lasted from 1130 until 1240. This war was also fought over the issue of succession. In 1217, Hakon Hakonsson was elected as king and after putting down some continued rebellion he was able to secure his position as king (Derry 1979). The English Wars of the Roses (1455-1485) were fought between competing York and Lancaster branches of the Plantagenet dynasty. Over thirty years numerous members of the royal family were murdered/executed in the quest to secure political control. Additional wars were fought between the Habsburg branches in Spain and Germany as well as the Habsburg-French struggles (1494-1559), and the Wars of the Castilian Succession (1475-1479).

Marriage alliances were one method to combat inter-familial conflict. Duby (1978) found that in France women of marriageable age were the means by which to secure political alliances. At the same time he also argued that male heirs were more likely to wed while younger sons, referred to as cadet sons, were less likely to marry and were forced into careers in the military or the church. For example, Henry Lord of Bourbourg (France) had seven sons and five daughters. His first son made an advantageous marriage. His next two sons were sent to the Church, the next three sons died in the following manners: young, as a knight, and blinded in a tournament respectively. This left only the youngest son. The eldest son died without an heir and so an arrangement was made for this last son to marry his eldest brother's widow. The five daughters of the Lord of Bourbourg did not fare much better. The eldest daughter made a 
good match. The second daughter was also married, but to a man with a less important title. The third daughter had a marriage arranged with a local lord from the Rhineland. The remaining two daughters spent their lives in the family's convent (Duby 1983).

A similar pattern was found among the English aristocratic families. Sons were more likely to remain unmarried than daughters (Hollingsworth 1957). Boone (1986) found that among the Portuguese nobility, elder daughters were more likely to marry than their younger counterparts. The aristocracy of medieval England and France represented a population in a unique situation. There were large amounts of heritable wealth which were required to be divided along specific inheritance patterns. The next chapter will review the fifteen families that were included in this sample. A brief history of each family will be discussed as well as a more thorough examination of the founders of each line and their descendants. 


\section{Chapter Four: History of Focal Families}

\section{The L'Aigle family}

The L'Aigle family originated in France sometime during the early part of the eleventh century. Fulbert de Beina was the earliest known member of the L'Aigle family. The family took its name from a small town located on the south eastern border of Normandy. Fulbert de Beina was succeeded by his son Engenulf. His daughter Hiltrude would make an advantageous marriage with a local French lord, William fitz Giroie, a powerful Norman land holder, bringing additional wealth and political connections to the family. Engenulf's son, Richard was the progenitor of the L'Aigle family in this sample. Richard was born in 1055, the second son of Engeraulf and Richvaride. Both Engeraulf and Richard would serve William the Conqueror ultimately losing their lives at the Battle of Hastings and the Siege of Saint-Suzanne respectively.

Richard married Judith, daughter of Richard le Goz Viscount of Avranches and Emma de Conteville, the half-sister of William the Conqueror. This marriage indicated a significant rise in the status of the family. Their son Richard would hold two English manors, Witley and Mildenhall in Surrey and Suffolk respectively, along with their French holdings. The L'Aigle family remained in France until the duchy of Normandy fell to the French crown in the thirteenth century. 


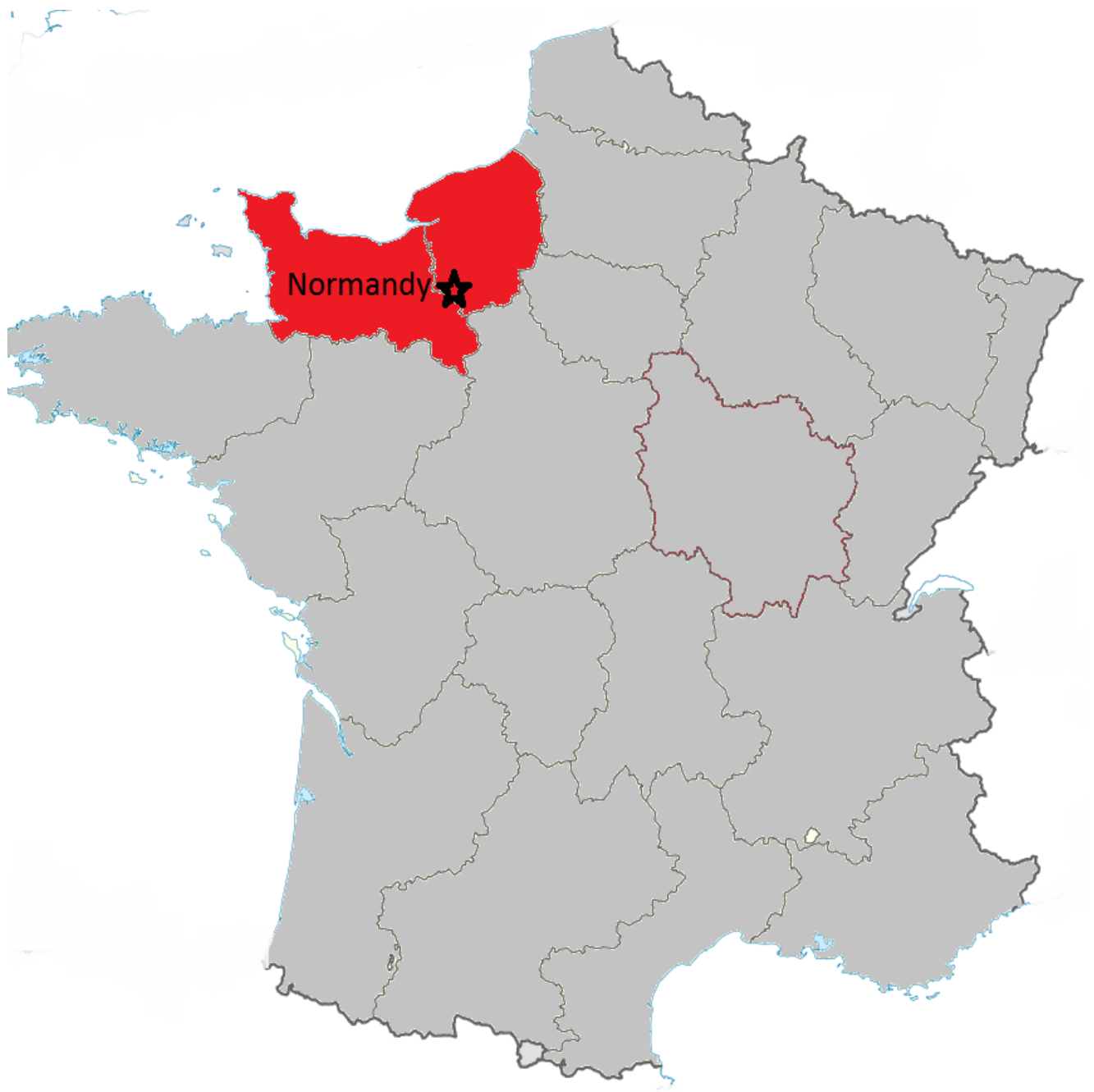

Figure 4.1: Location of the L'Aigle lands in Normandy

Adapted from:https://www.chateauxpourtous.fr/france-1-medieval-homes-houses-withdungeon-for-sale-in-France-medieval-castles-ruins-for-sale.php

The descendants of Richard would go on to marry into multiple families within the Anglo-Norman nobility as well as numerous other European aristocratic families. These marriages would again elevate the status of the family. For example, Gilbert Lord of L'Aigle married Isabel de Warenne, the daughter of Hamelin de Warenne, Earl of Surrey (half-brother of Henry II King of England) and Isabel de Warenne, Countess of Surrey (heiress to the de Warenne family, one of the most powerful Anglo-Norman 
families in England). The last of the L'Aigle family died without heirs shortly after the loss of the family's Norman lands (Chibnall 1984; 1987). Members of the L'Aigle family would serve the Norman (William I, William II, Robert II, Henry I, and Matilda), Blois (Stephen) and Plantagenet kings (Henry II, Richard I, John, and Henry III) until the first half of the $13^{\text {th }}$ century.

Table 4.1. L'Aigle family demographics

\begin{tabular}{lc}
\hline Variable & $N$ \\
\hline Generations & 10 \\
Individuals in sample & 837 \\
Males & 440 \\
Females & 397 \\
Progeny of Progenitor & \\
Total Children & 3 \\
Sons & 2 \\
Daughters & 1 \\
Total Grandchildren & 7 \\
Grandsons & 6 \\
Granddaughters & 1 \\
Total Great-grandchildren & 8 \\
Great-Grandsons & 5 \\
Great-Granddaughters & 3 \\
Total Great-great-grandchildren & 19 \\
Great-Great-Grandsons & 15 \\
Great-Great-Granddaughters & 4 \\
\hline
\end{tabular}

\section{The Bigod family}

The Bigod family had relatively obscure origins as knights in Normandy. The first record of the Bigod family appears in the household of William of Normandy (later William I King of England). The first member of the family to arrive in England was Roger Bigod. He was part of the Norman Conquest and was awarded with estate lands in East Anglia. According to the Domesday Book (1086) Roger held 6 lordships in Essex, 117 in Suffolk, and 187 in Norfolk. Five of Roger's descendants would hold the title, Earl of Norfolk (See Figure 4.2). 


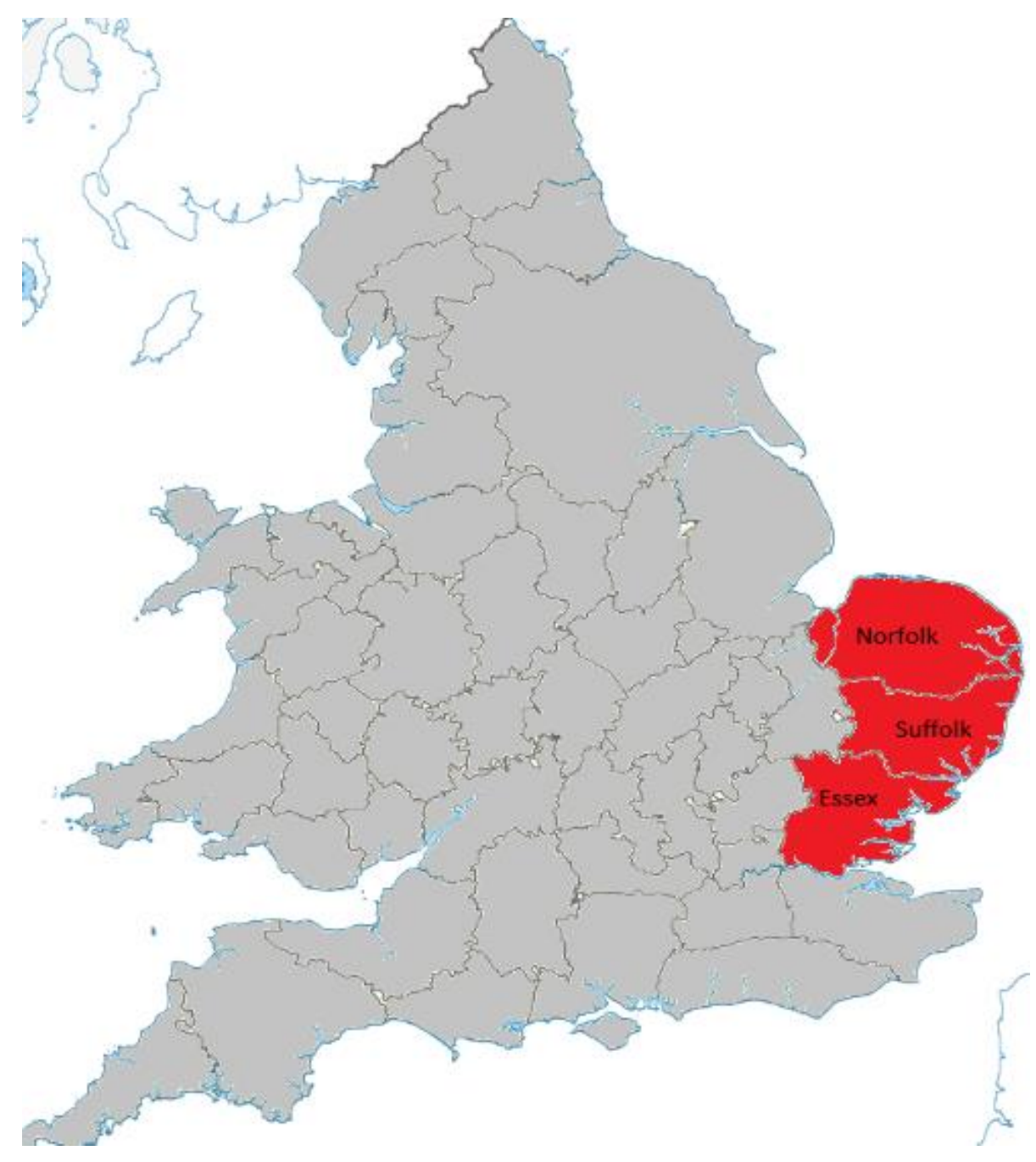

Figure 4.2: Bigod land in eastern England Adapted from: https://www.ancient.eu/image/9474/map-of-domesday-book-circuits/

Hugh Bigod, the second generation of the family in England, fought on the side of Stephen during the Anarchy. He later supported Henry the Young King in his campaign against his father, Henry II. After the defeat of Henry the Young King, Hugh Bigod was ordered to surrender his castles to the crown (Bartlett, 2000). Despite this, he did manage to maintain his lands and title. He married twice, each time into a powerful political family. His first wife was Juliane de Vere, the daughter of Aubrey de Vere II and 
Adeliza de Clare. His second marriage was to Gundreda, the daughter of Roger de Beaumont, $2^{\text {nd }}$ Earl of Warwick (Morris 2005).

Roger, $2^{\text {nd }}$ Earl of Norfolk, the son of Hugh Bigod and the grandson of the first Roger Bigod, was a travel companion of King John. He was also one of the Magna Carta sureties with both his and his son, Hugh, who ensured the king's adherence to the terms set forth. Successive generations of the Bigod family would marry into the Marshal and d'Aubigny families (Cokayne). Despite their political success, the Bigod family was relatively short lived. The last male of the Bigod family, Roger $5^{\text {th }}$ Earl of Norfolk, died childless in 1306. The title Earl of Norfolk reverted back to the crown. It would eventually be bestowed on Thomas of Brotherton, the son of Edward I, King of England.

Table 4.2. Bigod family demographics

\begin{tabular}{ll}
\hline Variable & $N$ \\
\hline Generations & 5 \\
Individuals in sample & 28 \\
Males & 16 \\
Females & 12 \\
Progeny of Progenitor & \\
Total Children & 1 \\
Sons & 1 \\
Daughters & 0 \\
Total Grandchildren & 3 \\
Grandsons & 3 \\
Granddaughters & 0 \\
Total Great-grandchildren & 4 \\
Great-Grandsons & 4 \\
Great-Granddaughters & 2 \\
Total Great-great-grandchildren & 3 \\
Great-Great-Grandsons & 2 \\
Great-Great-Granddaughters & 1 \\
\hline
\end{tabular}


Figure 4.3: Bigod Family Genealogical Chart created by author in Geno Pro

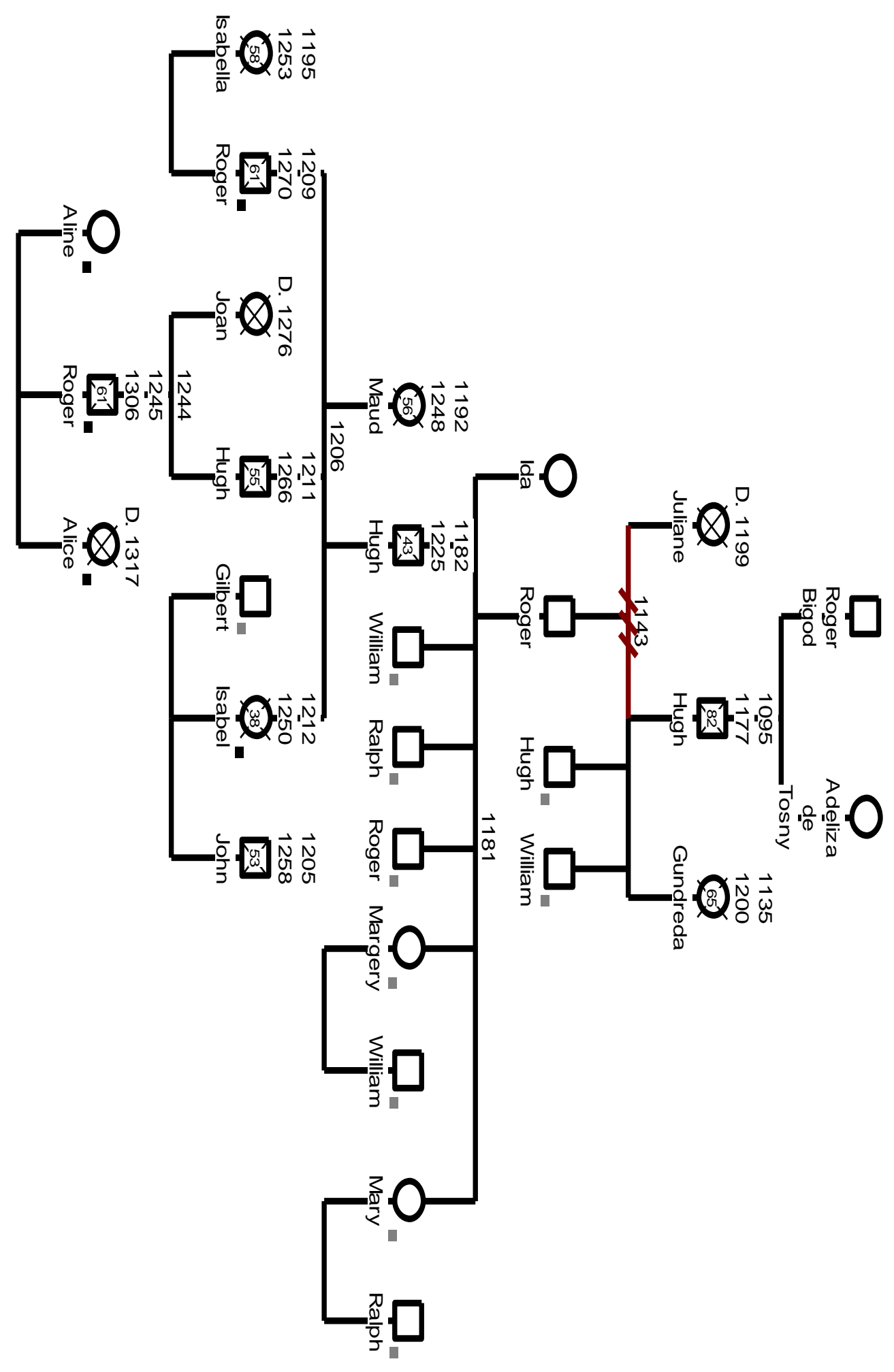




\section{The Brus family}

The Brus (Bruce) family of Scotland descended from Robert de Brix, a Norman knight and companion of William of Normandy. Brix was located in the northern most portion of Normandy. As reward for his support in the campaign, William gave Robert land in Yorkshire. Robert's son, another Robert, would receive the lordship of Annandale in Scotland. The grandson of Robert II (Robert $4^{\text {th }}$ Lord of Annandale) married Isobel of Huntingdon, the daughter of David $8^{\text {th }}$ Earl of Huntingdon (the grandson of the King of Scotland). This marriage brought Robert (IV) land and two manors in Essex. The son of Robert IV and Isobal of Huntingdon would later marry Isabella de Clare, the maternal granddaughter of William Marshal. This marriage would produce yet another Robert, (the Bruce), who would later become one of the claimants for the Scottish throne (Blakely, 2005). 


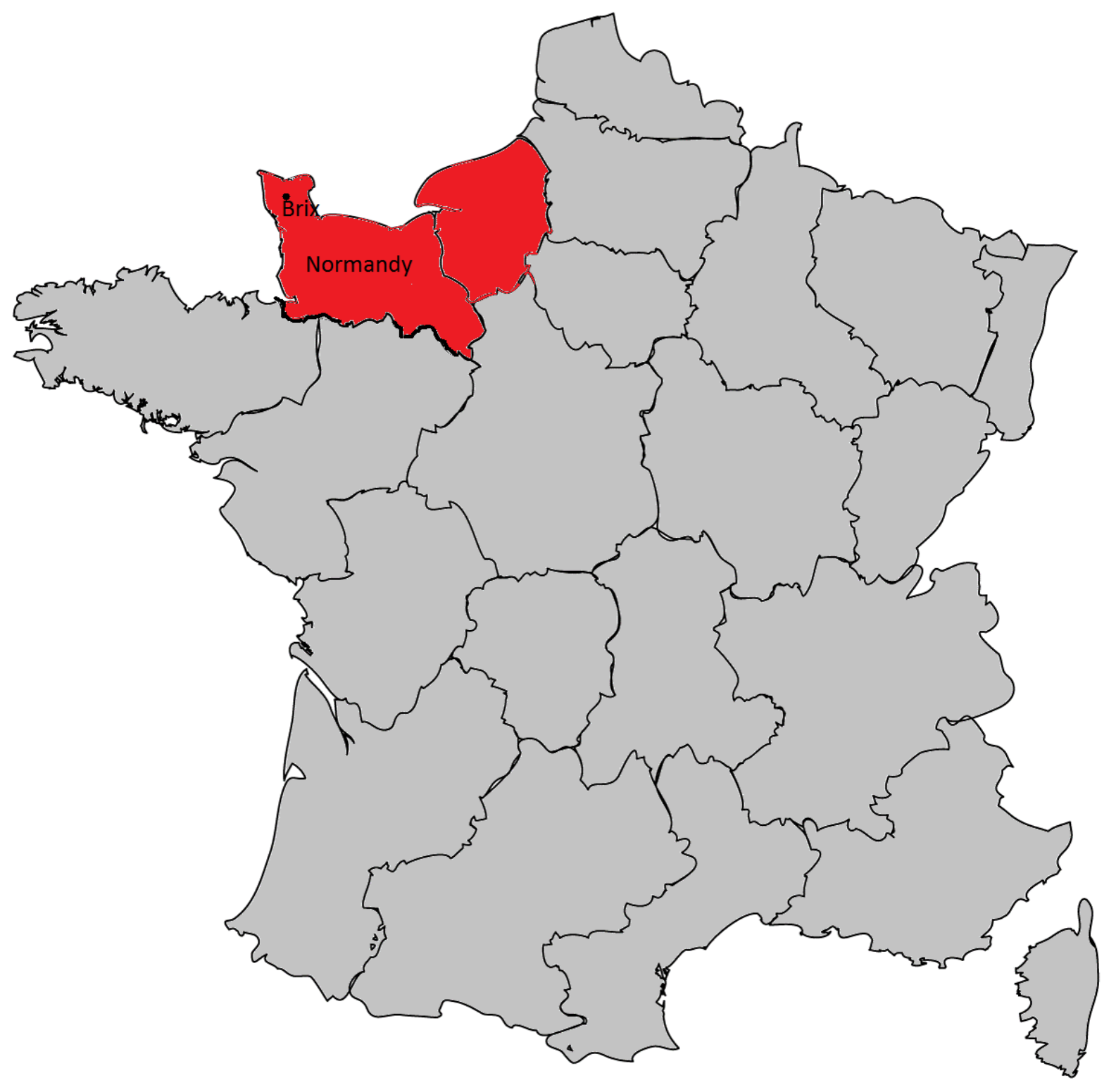

Figure 4.4: Brus lands in Normandy. Adapted from:https://www.chateauxpourtous.fr/france-1-medieval-homes-houses-with-dungeonfor-sale-in-France-medieval-castles-ruins-for-sale.php 


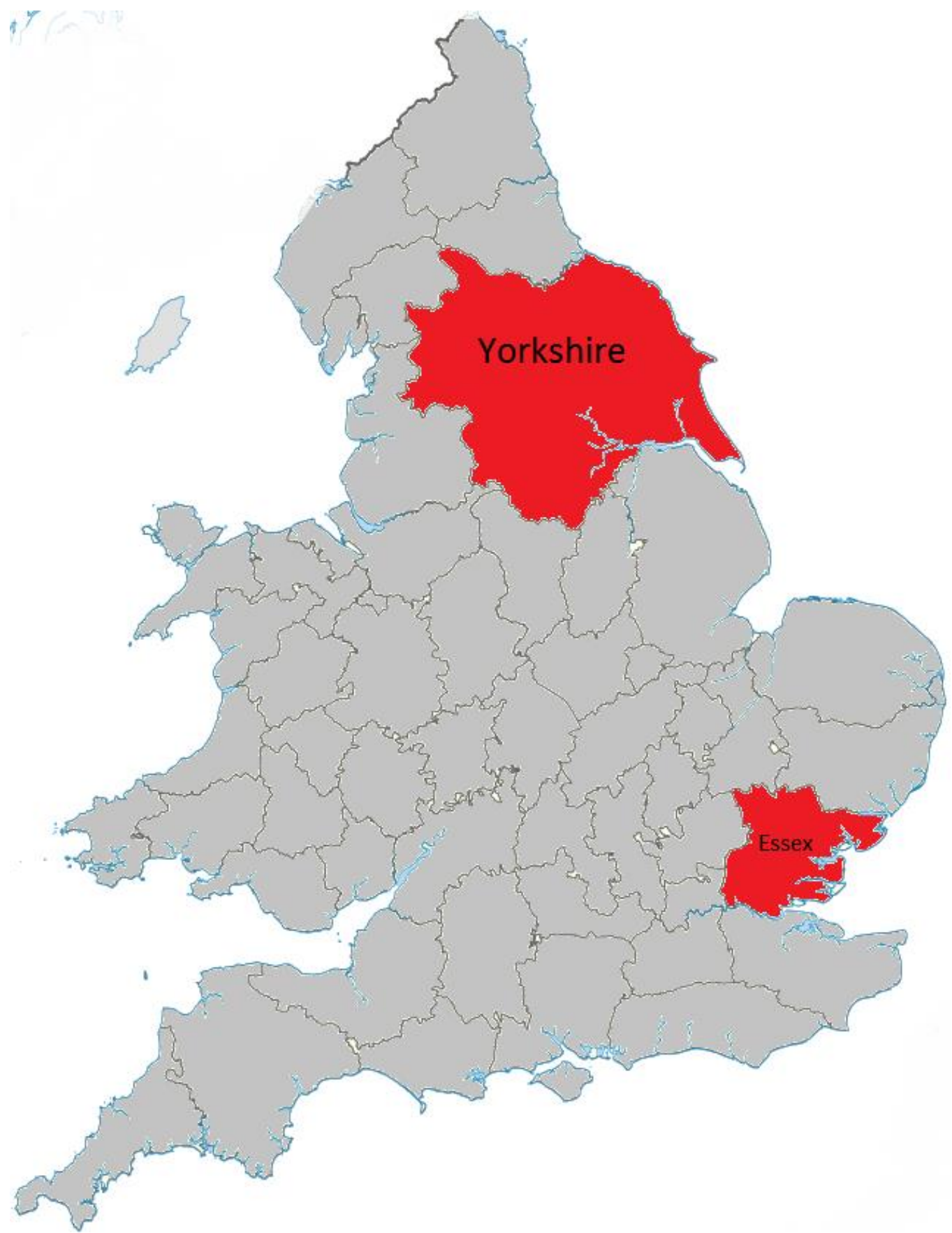

Figure 4.5: Brus lands in England

Adapted from: https://www.ancient.eu/image/9474/map-of-domesday-book-circuits/ 


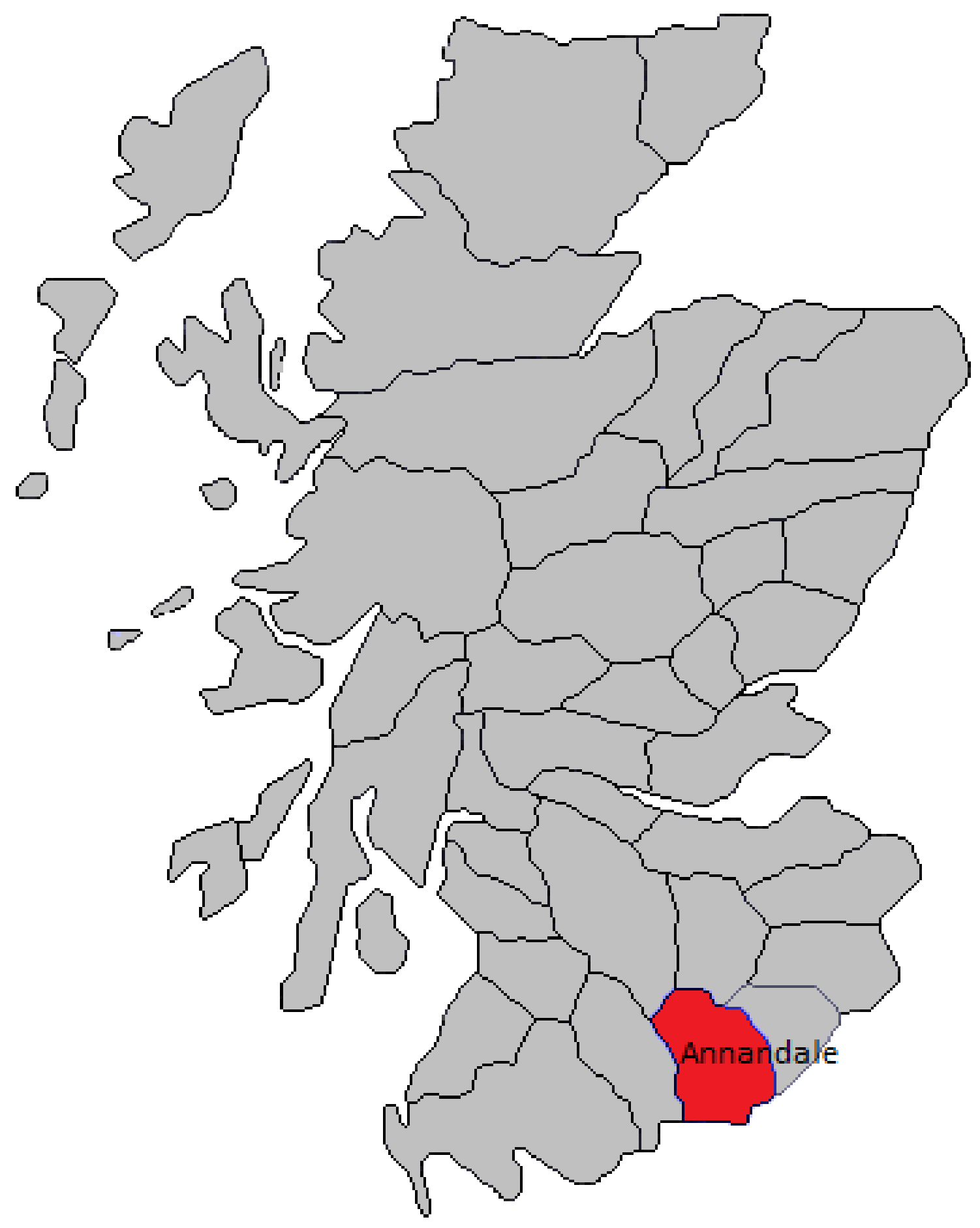

Figure 4.6: Brus lands in Scotland Adapted from:

https://www.undiscoveredscotland.co.uk/usfeatures/areas/indexto1890.html 
Table 4.3. Brus family demographics

\begin{tabular}{lc}
\hline Variable & $N$ \\
\hline Generations & 8 \\
Individuals in sample & 74 \\
Males & 40 \\
Females & 34 \\
Progeny of Progenitor & \\
Total Children & 5 \\
$\quad$ Sons & 3 \\
Daughters & 2 \\
Total Grandchildren & 3 \\
Grandsons & 2 \\
Granddaughters & 1 \\
Total Great-grandchildren & 2 \\
Great-Grandsons & 2 \\
Great-Granddaughters & 0 \\
Total Great-great-grandchildren & 5 \\
Great-Great-Grandsons & 4 \\
Great-Great-Granddaughters & 1 \\
\hline
\end{tabular}


Figure 4.7: Brus Family Genealogical Chart created by author in Geno Pro

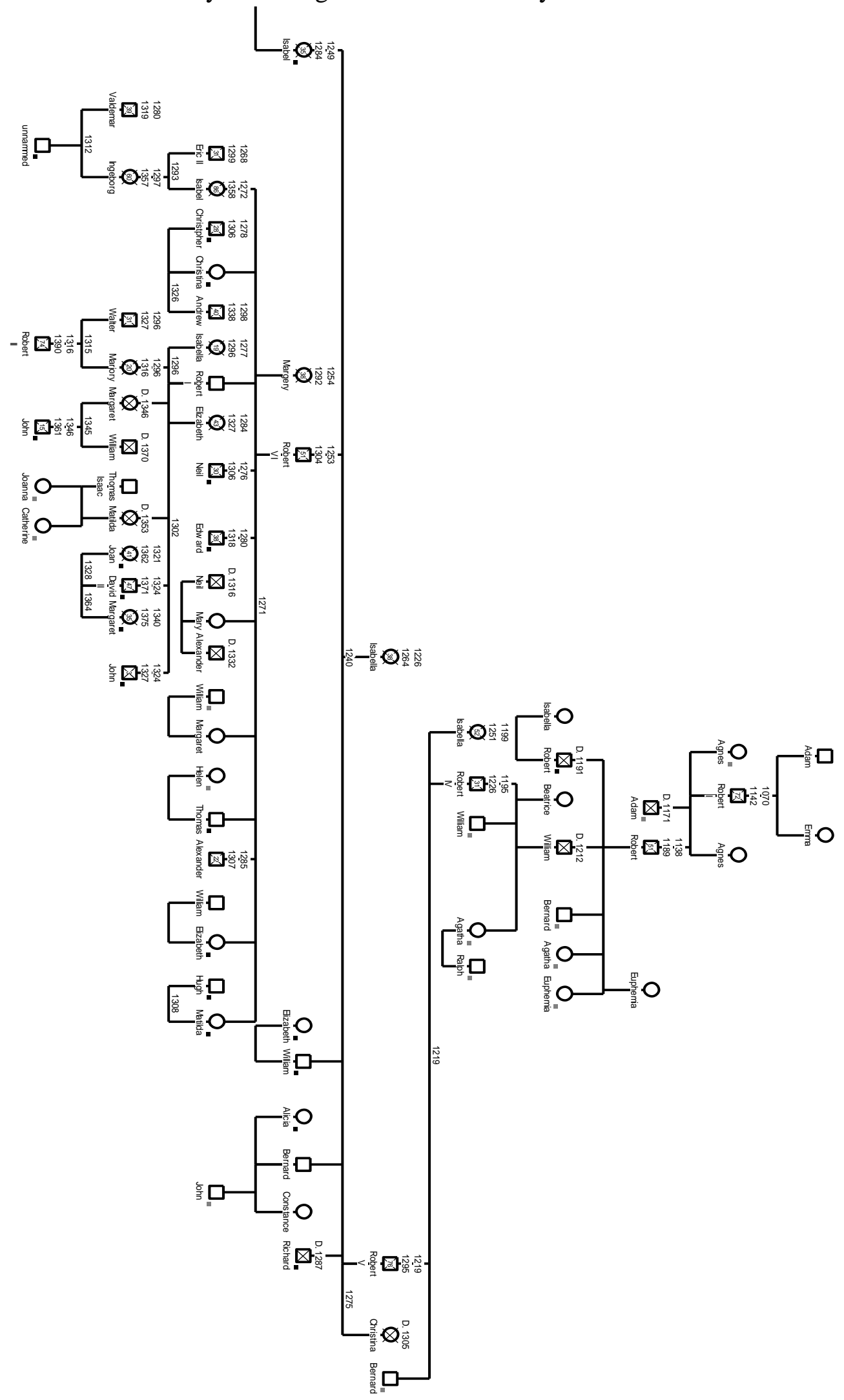




\section{The House of Godwin}

The House of Godwin was one of several Anglo-Danish noble families in England prior to the Norman invasion. The progenitor of the house was Earl Godwin who held the earldom of Wessex from 1020. His father was Anglo-Saxon, but nothing is known about his mother. He was given this title by King Cnut and was able to maintain the title through the reign of Harold Harefoot and Harthacnut (the sons of Cnut). The Godwin family rose to prominence quickly and would later acquire land in East Anglia, and Northumbria. Godwin married Gytha Thorkelsdottir, an Anglo-Danish woman, who was the daughter of a Danish chieftain. Through the marriage of his youngest daughter Edith to Edward the Confessor the family was able to consolidate their power. When Edward died childless in January 1066, his brother-in-law Harold became Harold II and ruled until the Norman invasion in October 1066. After his death at the Battle of Hastings, his sons were sent into exile or captured by the Normans. His two daughters remained in England, the eldest joined a convent and took vows although she later left under uncertain circumstances. His youngest daughter, Gytha, married Vladimir II, the ruler of Kievan Rus (Mason 2004). The descendants of Harold would eventually marry into numerous other European aristocratic families. Most modern European royal families can trace their heritage back to the female descendants of Godwin (Barlow, 2013). 


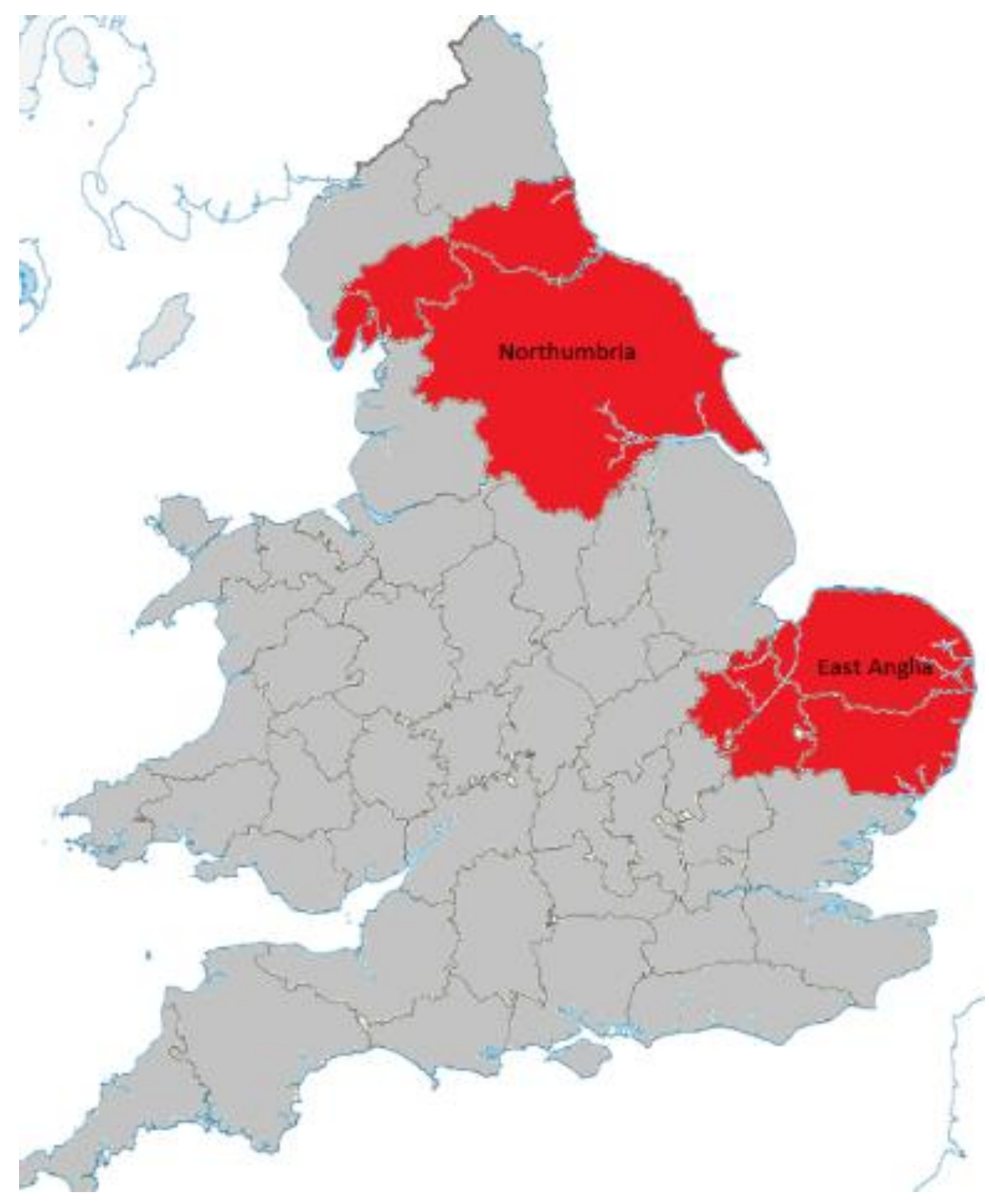

Figure 4.8: Godwin lands in England Adapted from: https://www.ancient.eu/image/9474/map-of-domesday-book-circuits/ 
Table 4.4. Godwin family demographics

\begin{tabular}{lr}
\hline Variable & $N$ \\
\hline Generations & 12 \\
Individuals in sample & 2406 \\
Males & 1266 \\
Females & 1140 \\
Progeny of Progenitor & 11 \\
Total Children & 7 \\
$\quad$ Sons & 4 \\
Daughters & 10 \\
Total Grandchildren & 8 \\
Grandsons & 2 \\
Granddaughters & 6 \\
Total Great-grandchildren & 5 \\
Great-Grandsons & 1 \\
Great-Granddaughters & 14 \\
Total Great-great-grandchildren & 7 \\
$\quad$ Great-Great-Grandsons & 7 \\
$\quad$ Great-Great-Granddaughters &
\end{tabular}

\section{The Marshal family}

The Marshal family was one of the most important families in the database in terms of their political connections. The originator of the family, in the sample, was William Marshal. Marshal was a knight at the court of Henry II, King of England. As a reward for his service, in 1189 he was married to Isabel de Clare, the daughter and heiress of the powerful Richard de Clare (Strongbow) who had led the Norman invasion of Ireland. Upon marriage, William Marshal was given the palatine lordships of Pembroke and Striguilin in Wales as well as the Lordship of Leinster in Ireland. He also acquired land in Wales and Ireland as well as in Normandy. 


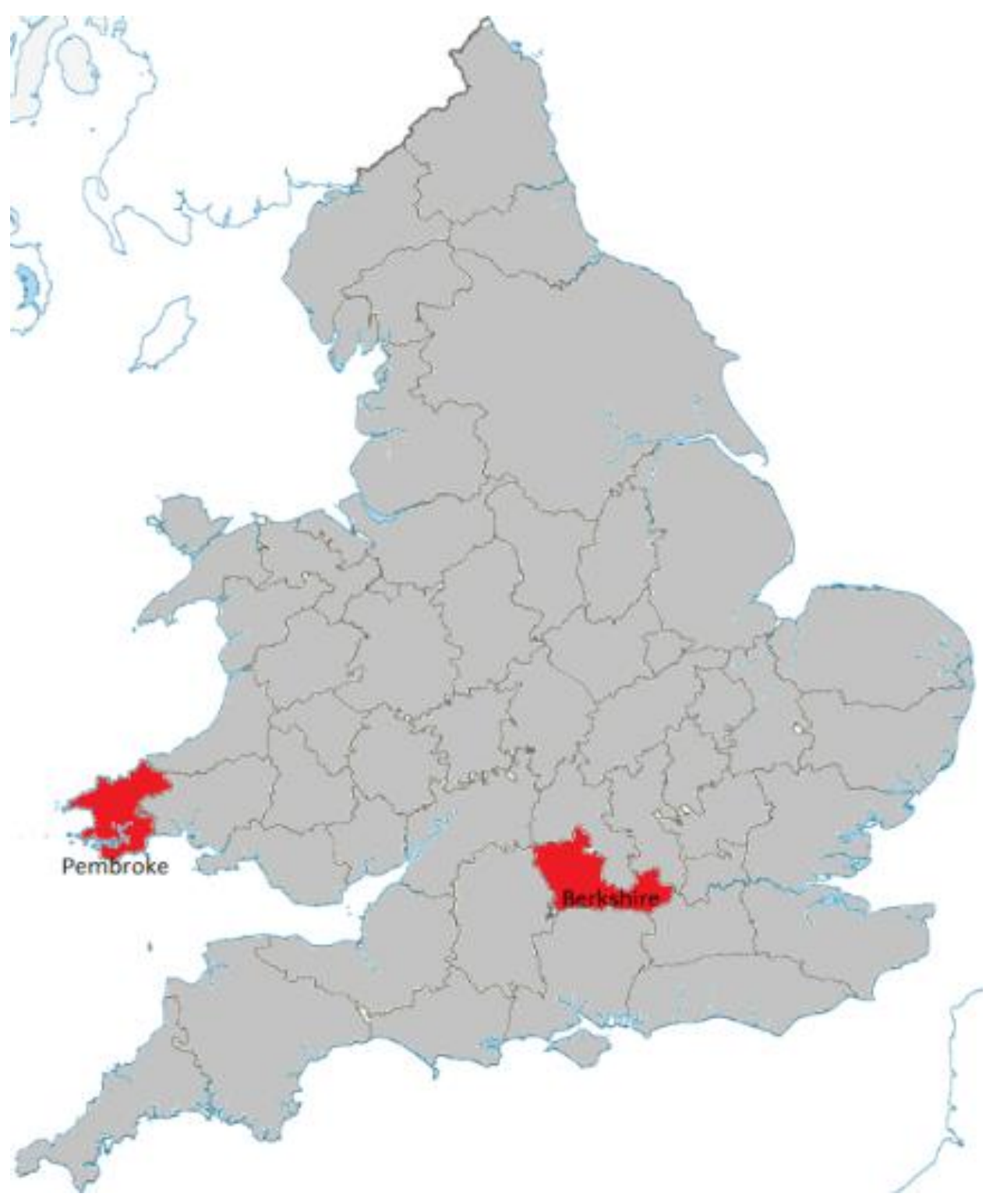

Figure 4.9: Marshal lands in England and Wales

Adapted from: https://www.ancient.eu/image/9474/map-of-domesday-book-circuits/ 
Over the course of his life, Marshal served five kings of England, Henry II, the 'Young King' Henry, Richard I, John and Henry III. During his term with King John he was a signatory of Magna Carta. William and Isabel produced ten children over the course of their marriage (five sons and five daughters). Legend says that during the civil war in Ireland, William Marshal laid claim to two manors belonging to a member of the Irish clergy. As a result, a curse was placed upon his sons wherein none of them, would produce children and despite several marriages between the brothers, no heirs were produced (Gies and Gies 1990).

His daughters fared much better. All five married into prominent families including the Bigod, de Warenne, de Clare, Plantagenet, de Ferrers, de Braose, and de Munchensi families. The Marshal sisters produced 28 children collectively, most of whom made their own advantageous marriages. Through his daughters, Marshal became the ancestor to the Houses of both the Bruce and Stuart kings of Scotland, the last two Plantagenet kings (Edward IV and Richard III), as well as all of the English monarchs since Henry VIII (Duby, 1985). 


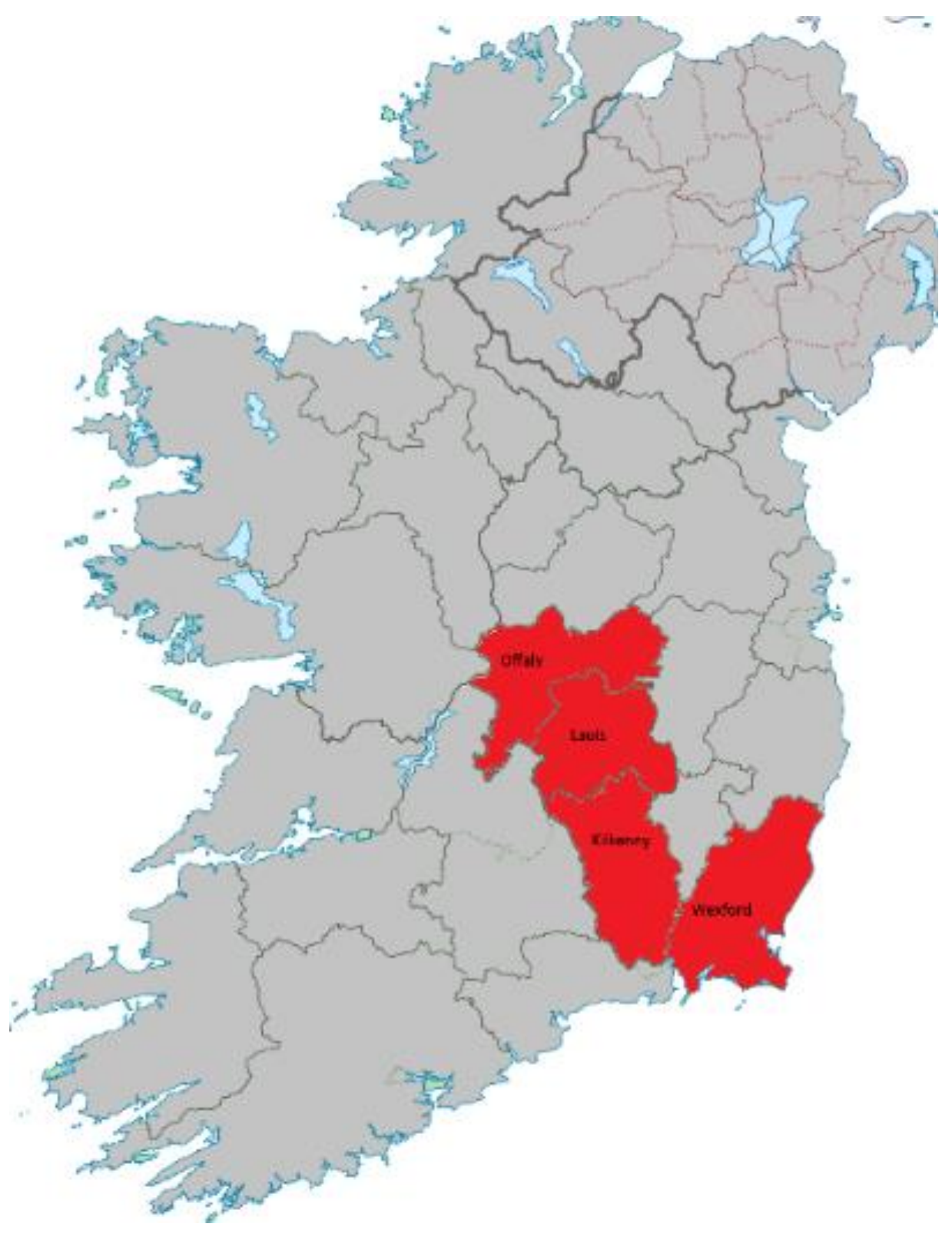

Figure 4.9: Marshal lands in Ireland

Adapted from: https://www.uni-due.de/IERC/IERC_Overview.htm 
Table 4.5. Marshal family demographics

\begin{tabular}{lr}
\hline Variable & $N$ \\
\hline Generations & 5 \\
Individuals in sample & 618 \\
Males & 324 \\
Females & 294 \\
Progeny of Progenitor & 10 \\
Total Children & 5 \\
Sons & 5 \\
Daughters & 28 \\
Total Grandchildren & 10 \\
Grandsons & 18 \\
Granddaughters & 58 \\
Total Great-grandchildren & 27 \\
Great-Grandsons & 30 \\
Great-Granddaughters & 68 \\
Total Great-great-grandchildren & 45 \\
Great-Great-Grandsons & 23 \\
Great-Great-Granddaughters &
\end{tabular}

\section{The House of Welf}

The House of Welf had multiple succeeding lines. One of those connections was Judith of Flanders, the daughter of Baldwin IV, Count of Flanders and Eleanor of Normandy making her the maternal first cousin of William the Conqueror. Her hand in marriage would have been closely monitored as can be seen by the political matches that were arranged. She was the first wife of Tostig Godwinson, son of Godwin (progenitor of the Godwin family discussed above) and his wife Gytha Thorkelsdattier. Upon Tostig's death, Judith married Welf I, Duke of

Bavaria. By marrying the consanguineous kin of William the Conqueror, Welf would have secured the position of his dynasty in the Norman/English aristocracy. The House of Welf held land in Burgundy from the ninth century. Unlike other families in the database, the Welf descendants only remained in France or England for a generation and then the family expanded outside. 


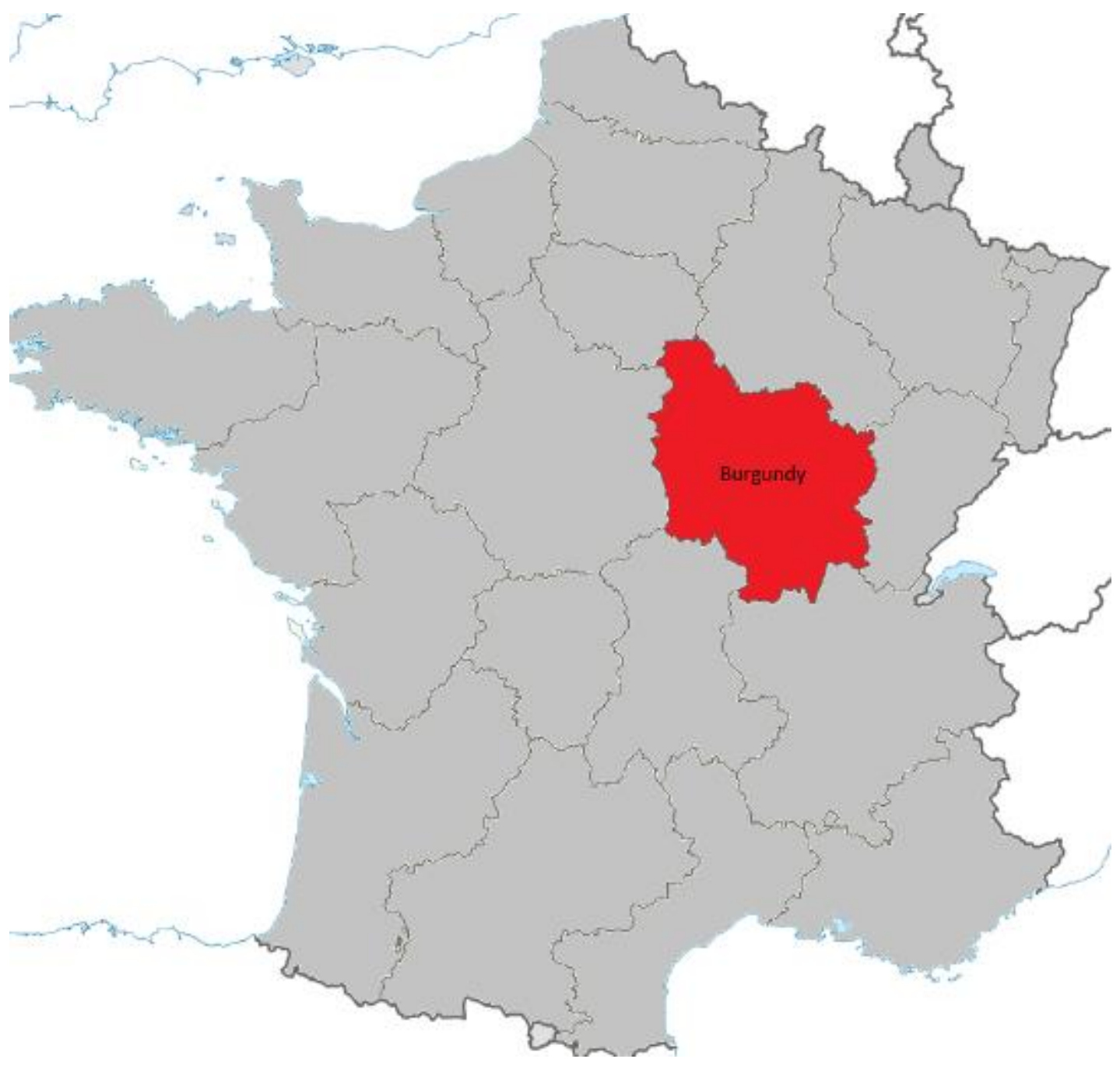

Figure 4.10: Welf lands in France Adapted from:

https://www.chateauxpourtous.fr/france-1-medieval-homes-houses-with-dungeon-forsale-in-France-medieval-castles-ruins-for-sale.php 
The family would branch out into several other European countries including England, Germany, Bavaria, Saxony, Russia, and Italy. While the Welf family could not be classified as French, due to their connections to William the Conqueror and their political significance, they were maintained within the database.

Table 4.6. Welf family demographics

\begin{tabular}{lr}
\hline Variable & $N$ \\
\hline Generations & 7 \\
Individuals in sample & 839 \\
Males & 958 \\
Females & 881 \\
Progeny of Progenitor & \\
Total Children & 3 \\
Sons & 2 \\
Daughters & 1 \\
Total Grandchildren & 8 \\
Grandsons & 5 \\
Granddaughters & 3 \\
Total Great-grandchildren & 11 \\
Great-Grandsons & 5 \\
Great-Granddaughters & 6 \\
Total Great-great-grandchildren & 26 \\
Great-Great-Grandsons & 17 \\
Great-Great-Granddaughters & 9 \\
\hline
\end{tabular}

\section{The de Montgomerie family}

The de Montgomerie family also had Anglo-Norman origins. Roger Montgomerie was the grand-nephew of Richard I Count of Rouen of the House of Normandy, the great grandfather of William the Conqueror. A second Roger de Montgomerie, son of the first Roger, was a chief counsellor of William and played a significant role in the Council of Lillebonne. The Montgomerie family held large tracks of land in central Normandy. Though his marriage to the heiress, Mabel de Belleme, Roger II also acquired a large territory spanning the border of Normandy and Maine. 


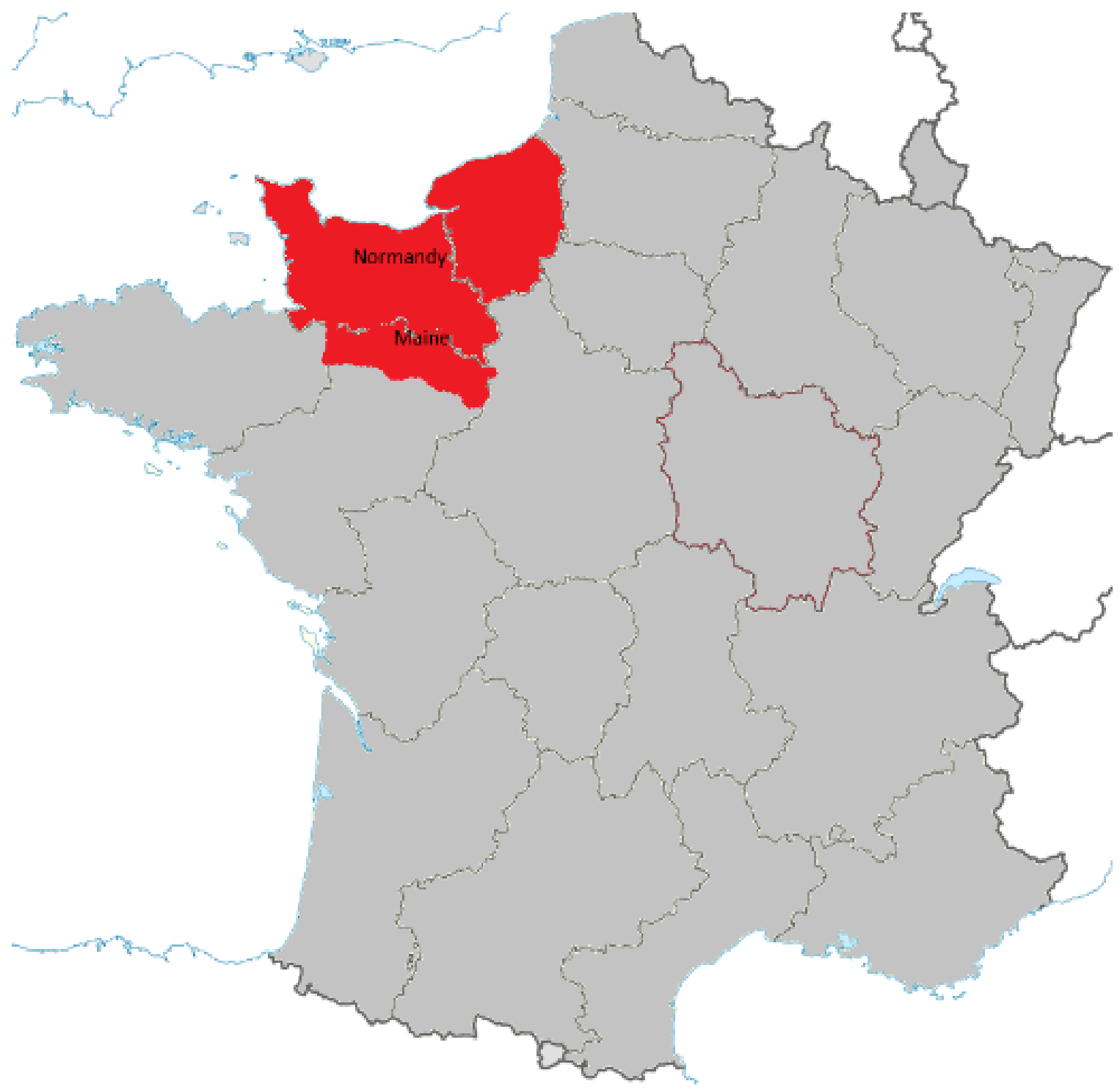

Figure 4.11: Montgomerie lands in France Adapted from:

https://www.chateauxpourtous.fr/france-1-medieval-homes-houses-with-dungeon-forsale-in-France-medieval-castles-ruins-for-sale.php

The Montgomery family figured prominently in politics. The first Roger Montgomery found himself in the middle of the succession conflict after William I's death. He initially sided against the heir, William II, but later backed him. When William 
was successful in securing his throne, some of the nobles who had not supported him lost their lands.

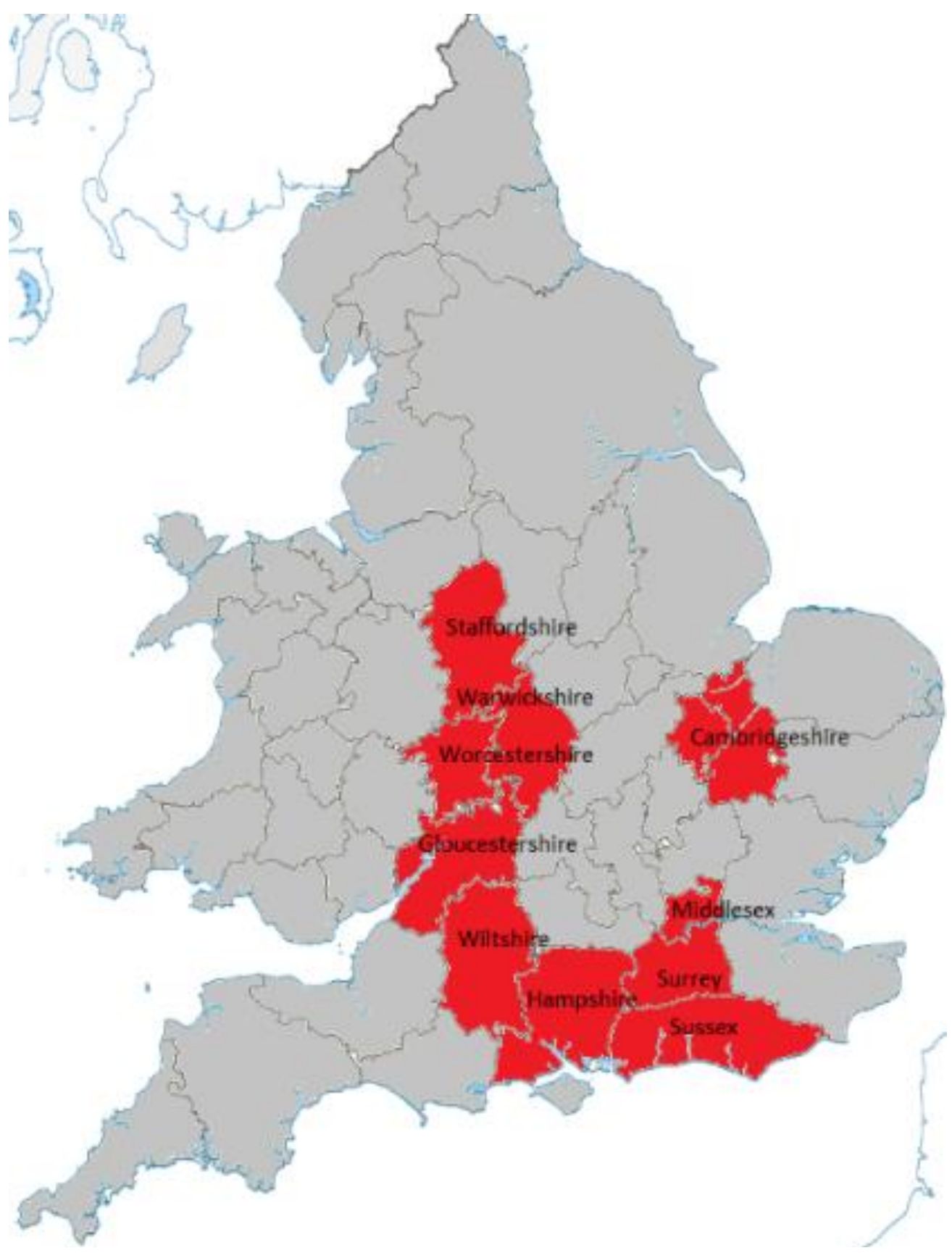

Figure 4.12: Montgomerie lands in England Adapted from: https://www.ancient.eu/image/9474/map-of-domesday-book-circuits/ 
In successive generations the family was rewarded with significant pieces of property and titles in Sussex (83 manors), estates in Surrey (4 manors), Hampshire (9 manors), Wiltshire (3 manors), Middlesex (8 manors), Gloucestershire (1 manor), Worcestershire (2 manors), Cambridgeshire (8 manors), Warwickshire (11 manors), and Staffordshire (30 manors) as well as the titles of the Earl of Shrewsbury and Earl of Arundel. The income from these estates totaled about $2,000 £$ per year approximately $3 \%$ of England's total economy in 1086 (Mason, 1963; Thompson, 1987). Like some of the other families in the sample, the Montgomerie family maintained their land in France even after the Norman invasion and continued to build the family holdings in both countries.

Table 4.7. Montgomerie family demographics

\begin{tabular}{lr}
\hline Variable & $N$ \\
\hline Generations & 11 \\
Individuals in sample & 1326 \\
Males & 687 \\
Females & 639 \\
Progeny of Progenitor & \\
Total Children & 10 \\
Sons & 6 \\
Daughters & 4 \\
Total Grandchildren & 12 \\
Grandsons & 5 \\
Granddaughters & 7 \\
Total Great-grandchildren & 15 \\
Great-Grandsons & 10 \\
Great-Granddaughters & 5 \\
Total Great-great-grandchildren & 22 \\
Great-Great-Grandsons & 12 \\
$\quad$ Great-Great-Granddaughters & 10 \\
\hline
\end{tabular}




\section{The Beaumont family}

Roger Beaumont is the first member of the Beaumont family in the database. $\mathrm{He}$ was a second cousin once removed from William the Conqueror. Roger married Countess Adeline of Meulan, the daughter Waleran III, Count de Meulan and Oda de Conteville. When the Norman invasion of England occurred in 1066, Roger was left to oversee William's interests in Normandy. His sons Robert and Henry were given land in England as a reward for the part they played in the Norman invasion as well as earldoms. Robert Beaumont was given more than 91 manors in England (Domesday Book). In addition he was created Earl of Leicester in 1107, a title that would pass through the next three generations of the family. He also inherited his mother's titles in Normandy, Count of Meulan, Viscount Ivry and Lord of Norton. Robert would marry Elizabeth (Isabel) daughter of Hugh Magnus (son the Henry I King of France) and Adelaide, Countess of Vermandois. Robert died in 1118 after which Elizabeth remarried to William de Warenne, $2^{\text {nd }}$ Earl of Surrey. 


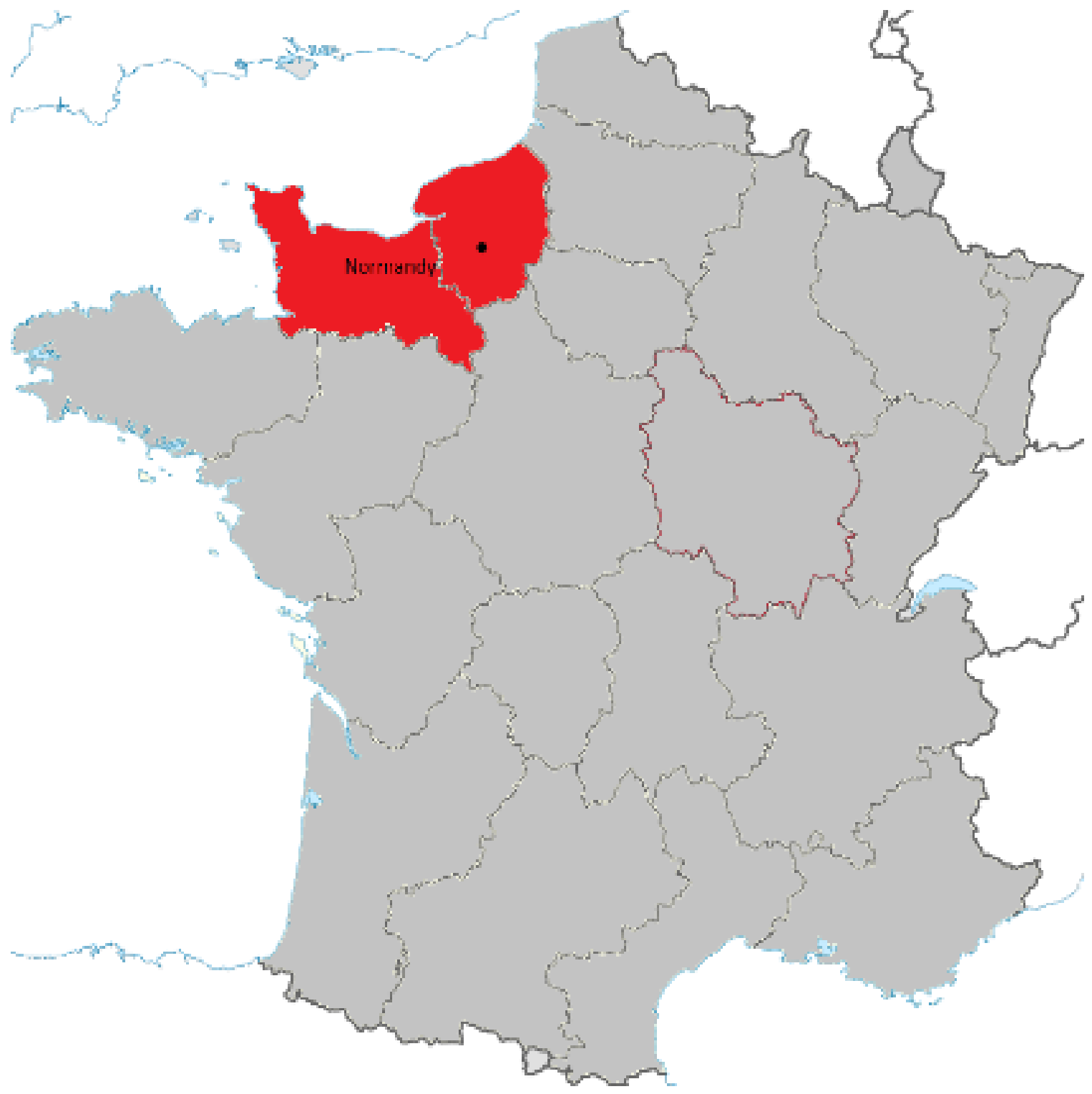

Figure 4.13: Beaumont lands in Normandy

Adapted from:https://www.chateauxpourtous.fr/france-1-medieval-homes-houses-withdungeon-for-sale-in-France-medieval-castles-ruins-for-sale.php 
Henry Beaumont was created the $1^{\text {st }}$ Earl of Warwick in 1088 as a reward for his assistance in the Rebellion of 1088. He was also given land in Warwickshire and Rutland as well as one of his father's lordships in Normandy. His descendants would continue to hold the title Earls of Warwick for several generations. He married Margaret, the daughter of Geoffrey II of Perche and Beatrix of Montdidier and had five children. This marriage would connect him with the L'Aigle family as well as the royal family of Navarre. His son, another Roger, would marry into the de Warenne family (marrying the daughter of William deWarenne $2^{\text {nd }}$ Earl of Surrey and Elizabeth of Vermandois (mentioned above).

Table 4.8. Beaumont family demographics

\begin{tabular}{lc}
\hline Variable & $N$ \\
\hline Generations & 11 \\
Individuals in sample & 343 \\
Males & 171 \\
Females & 172 \\
Progeny of Progenitor & \\
Total Children & 4 \\
Sons & 3 \\
Daughters & 1 \\
Total Grandchildren & 11 \\
Grandsons & 8 \\
Granddaughters & 3 \\
Total Great-grandchildren & 23 \\
$\quad$ Great-Grandsons & 13 \\
Great-Granddaughters & 10 \\
Total Great-great-grandchildren & 36 \\
$\quad$ Great-Great-Grandsons & 20 \\
Great-Great-Granddaughters & 16 \\
\hline
\end{tabular}




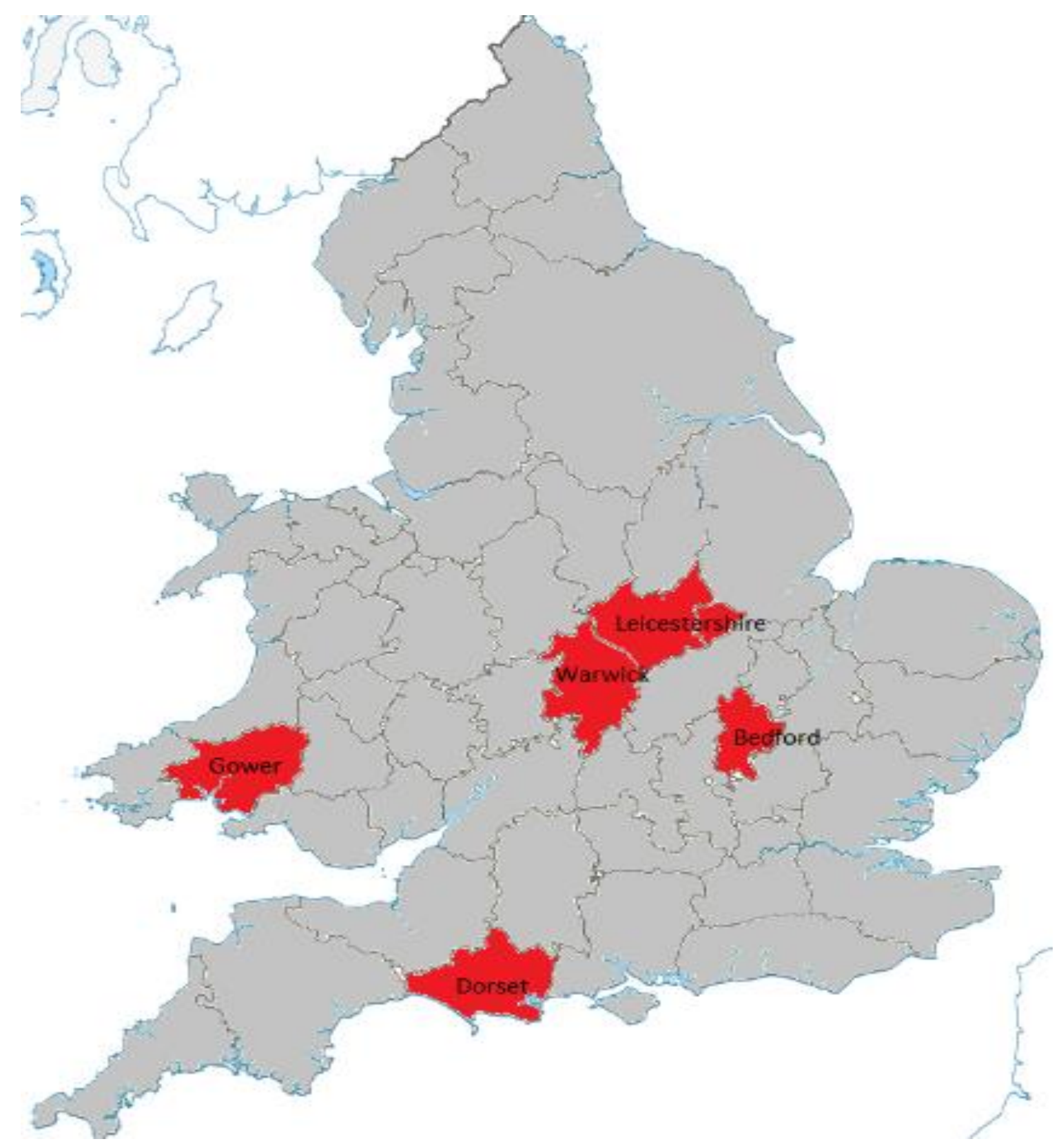

Figure 4.14: Beaumont lands in England Adapted from: https://www.ancient.eu/image/9474/map-of-domesday-book-circuits/ 


\section{The de Vere family}

The founder of the de Vere family in England was Aubrey. He first appeared in the Domesday Book in 1086 as the holder of fiefs in Essex (Castle Hedingham, Great Bentley, Great Canfield, Earls Colne, and Dovercourt) Cambridgeshire (Castle Camps, Hildersham, Silverley, and Wilbraham), Northamptonshire (Scaldwell and Wadenhoe), Middlesex (Kensington) and Suffolk (Aldham, Belstead, Lavenham, and Waldingfield). His son and grandson would go on to increase the landholdings and titles of the family to include additional land in Essex, the Lord Great Chamberlain position and the Earl of Oxford, a position that the family would hold for more than 500 years. The de Vere family has been referred to as one of the longest and most illustrious line of nobles that England has seen (Macaulay, 1857).

Table 4.9. de Vere family demographics.

\begin{tabular}{lc}
\hline Variable & $N$ \\
\hline Generations & 7 \\
Individuals in sample & 85 \\
Males & 47 \\
Females & 38 \\
Progeny of Progenitor & \\
Total Children & 10 \\
$\quad$ Sons & 4 \\
Daughters & 6 \\
Total Grandchildren & 10 \\
Grandsons & 9 \\
$\quad$ Granddaughters & 1 \\
Total Great-grandchildren & 8 \\
$\quad$ Great-Grandsons & 5 \\
Great-Granddaughters & 3 \\
Total Great-great-grandchildren & 8 \\
Great-Great-Grandsons & 4 \\
Great-Great-Granddaughters & 4 \\
\hline
\end{tabular}




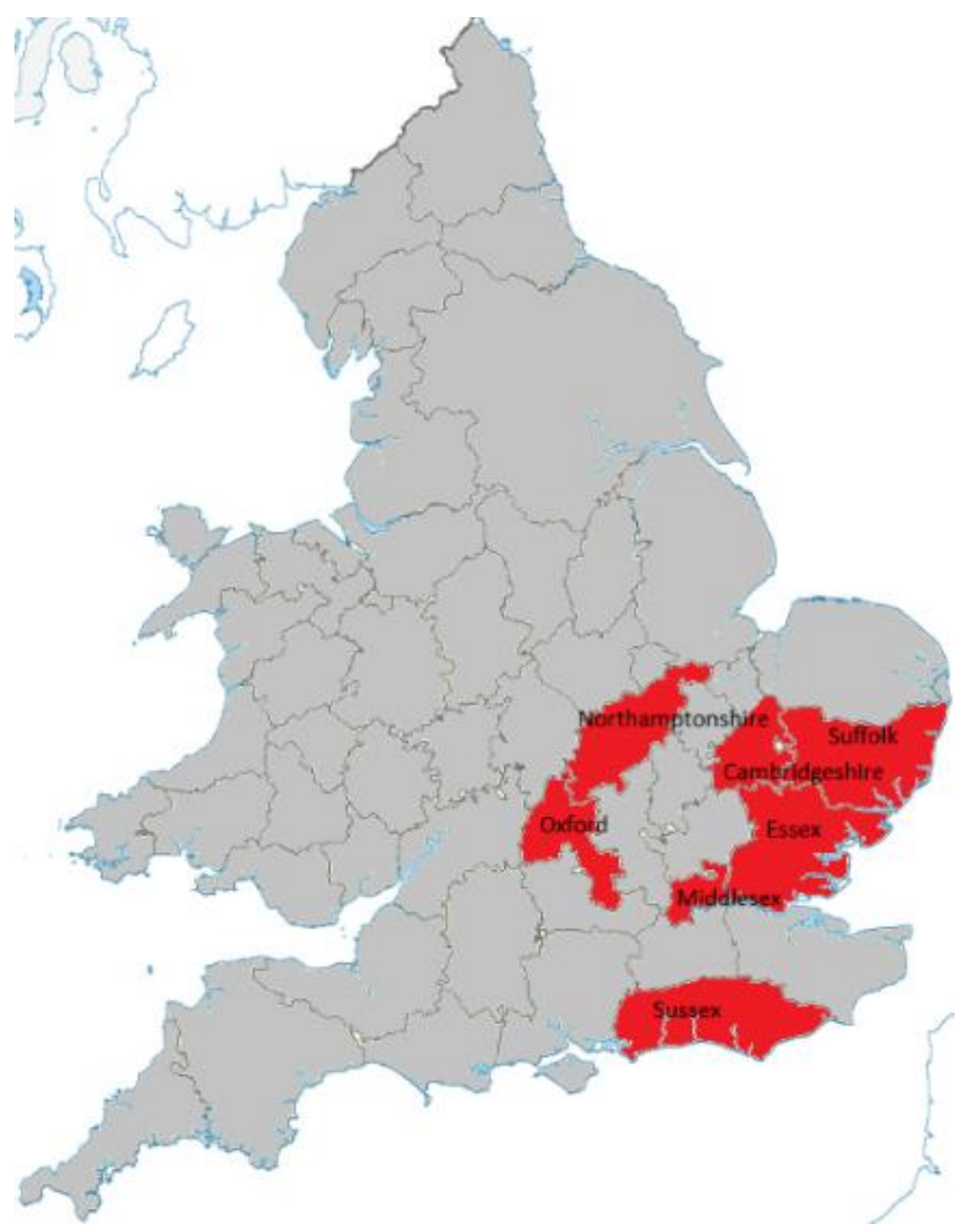

Figure 4.15: de Vere land in England Adapted from: https://www.ancient.eu/image/9474/map-of-domesday-book-circuits/ 
Figure 4.16: de Vere genealogy chart created by author in Geno Pro

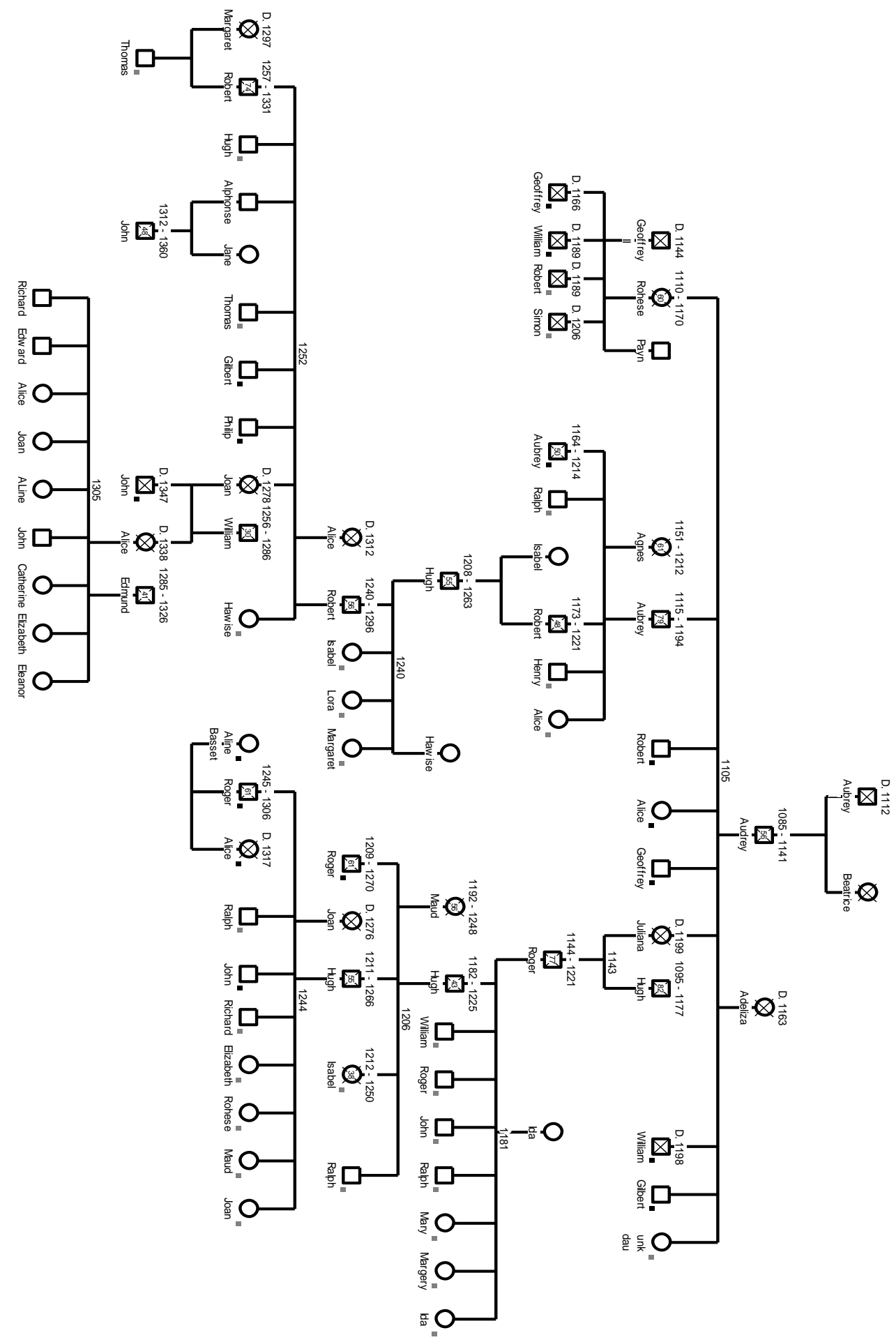




\section{The Avesnes family}

The Avesnes family was an important family in northern France. One branch of the family produced the powerful counts of Holland and Hainaut. The first person in the database was Nicholas d'Oisy, Lord of Avesnes, Leuze, and Conde'. He was the son of Walter I, Lord of Avesnes and his wife Ada of Tourani. He was married to Matilda de la Roche, a descendant of the powerful Counts of la Roche and Namur, and the Dukes of Lower Lorraine. Their children and grandchildren would become important figures in the Crusades. Their oldest son, James was a leader of the Third Crusade, commanding French, Flemish, and Frisian participants (Asbridge 2010). Their grandson, Walter II, held the lordships of Avesnes, Leuze, Conde and Guise. He married Margaret, Countess of Blois and Chartes, the daughter of Theobald V Count of Blois and Alix of France (the daughter of Louis VII, King of France and Eleanor of Aquitaine).

An inheritance dispute between the daughters, and only children, of Baldwin IX Count of Flanders, Count of Hainaut, Joan and Margaret led to a feud between the Avesnes family and the House of Dampierre. Margaret married Bouchard d'Avesnes much to the displeasure of her sister Joan. In addition to this, the two sisters also disagreed over Margaret's portion of their father's estate and as a result, Joan attempted to have Margaret's marriage annulled. The Pope condemned the marriage, but Margaret and Bouchard refused to accept the decision and continued to live with their children. In 1219, Bouchard was imprisoned as part of the dispute between the sisters and he was only released on the condition that the couple separate.

In the interim Joan convinced Margaret to remarry to William II of Dampierre, a powerful Champagne nobleman. Margaret would have children with both of her 
husbands which resulted in competition over Margaret's inheritance amongst the siblings.

Ultimately this led to a war of succession over Flanders and Hainault (Evergates 2007).

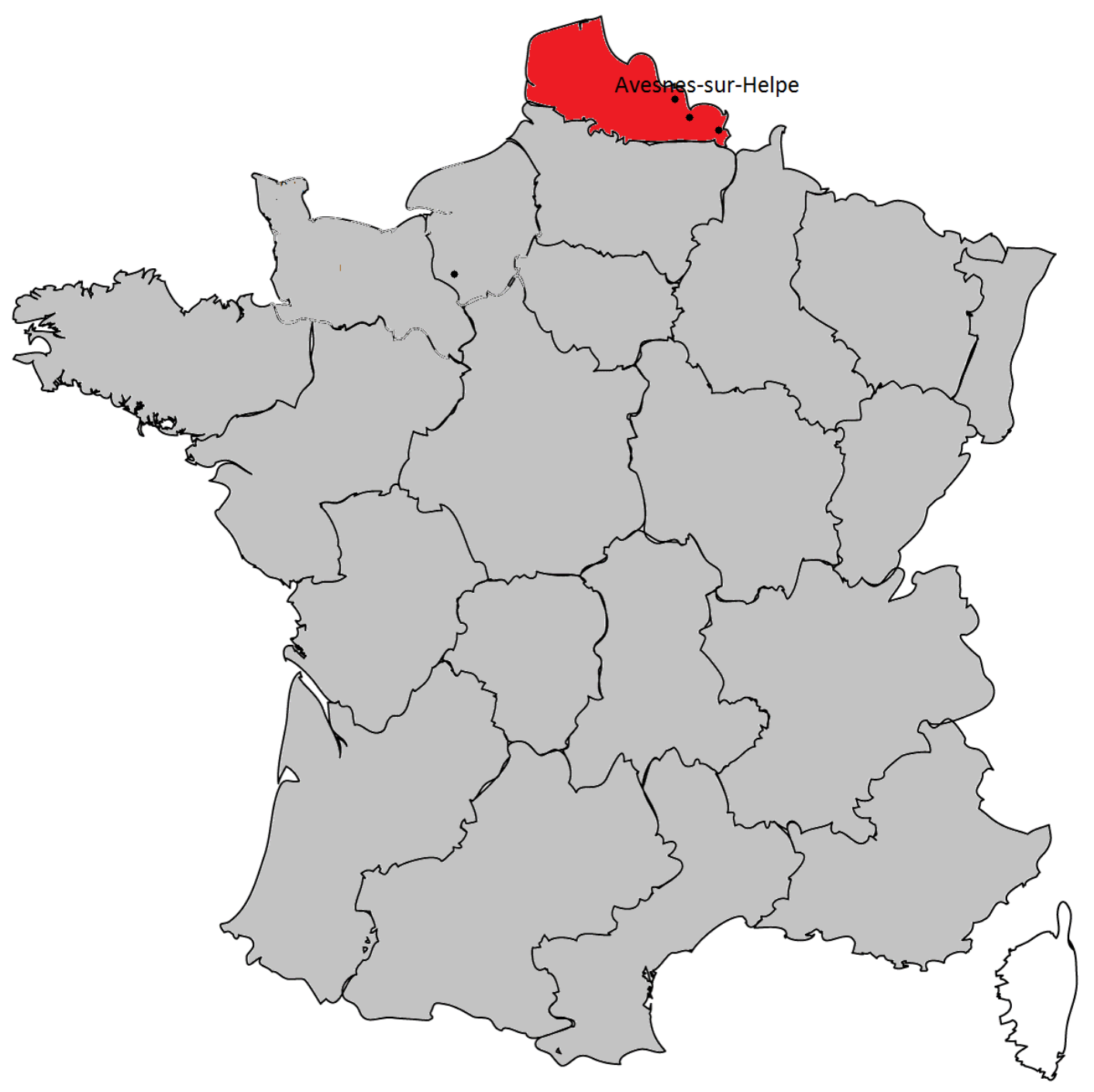

Figure 4.17: Avesnes lands in France

Adapted from:https://www.chateauxpourtous.fr/france-1-medieval-homes-houses-withdungeon-for-sale-in-France-medieval-castles-ruins-for-sale.php 
Table 4.10. Avesnes family demographics.

\begin{tabular}{lr}
\hline Variable & $N$ \\
\hline Generations & 7 \\
Individuals in sample & 212 \\
Males & 106 \\
Females & 106 \\
Progeny of Progenitor & \\
Total Children & 4 \\
Sons & 2 \\
Daughters & 2 \\
Total Grandchildren & 20 \\
Grandsons & 10 \\
Granddaughters & 10 \\
Total Great-grandchildren & 13 \\
Great-Grandsons & 6 \\
Great-Granddaughters & 7 \\
Total Great-great-grandchildren & 30 \\
Great-Great-Grandsons & 22 \\
Great-Great-Granddaughters & 8 \\
\hline
\end{tabular}


Figure 4.18a: Avesnes genealogy chart created by author in Geno Pro

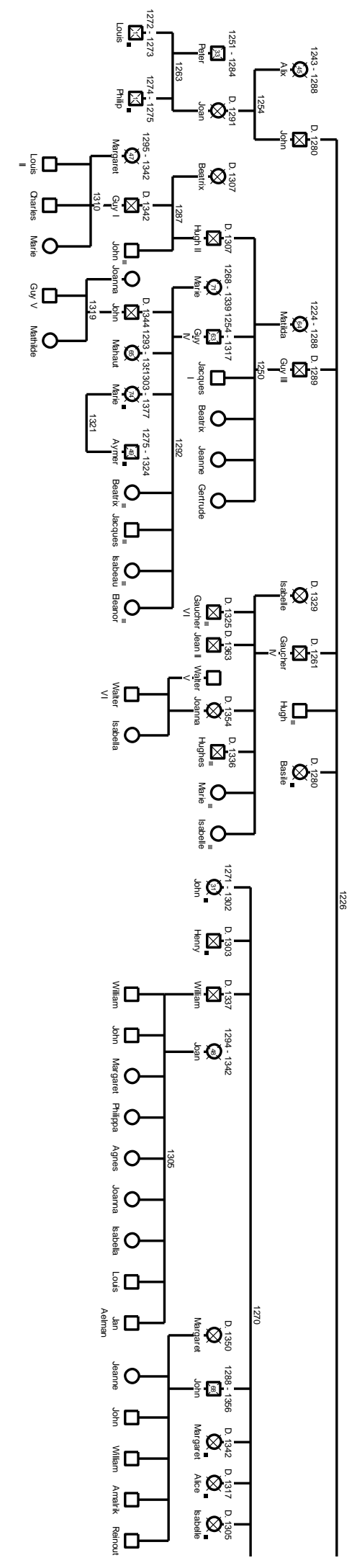


4.18b: Avesnes genealogy chart created by author in Geno Pro

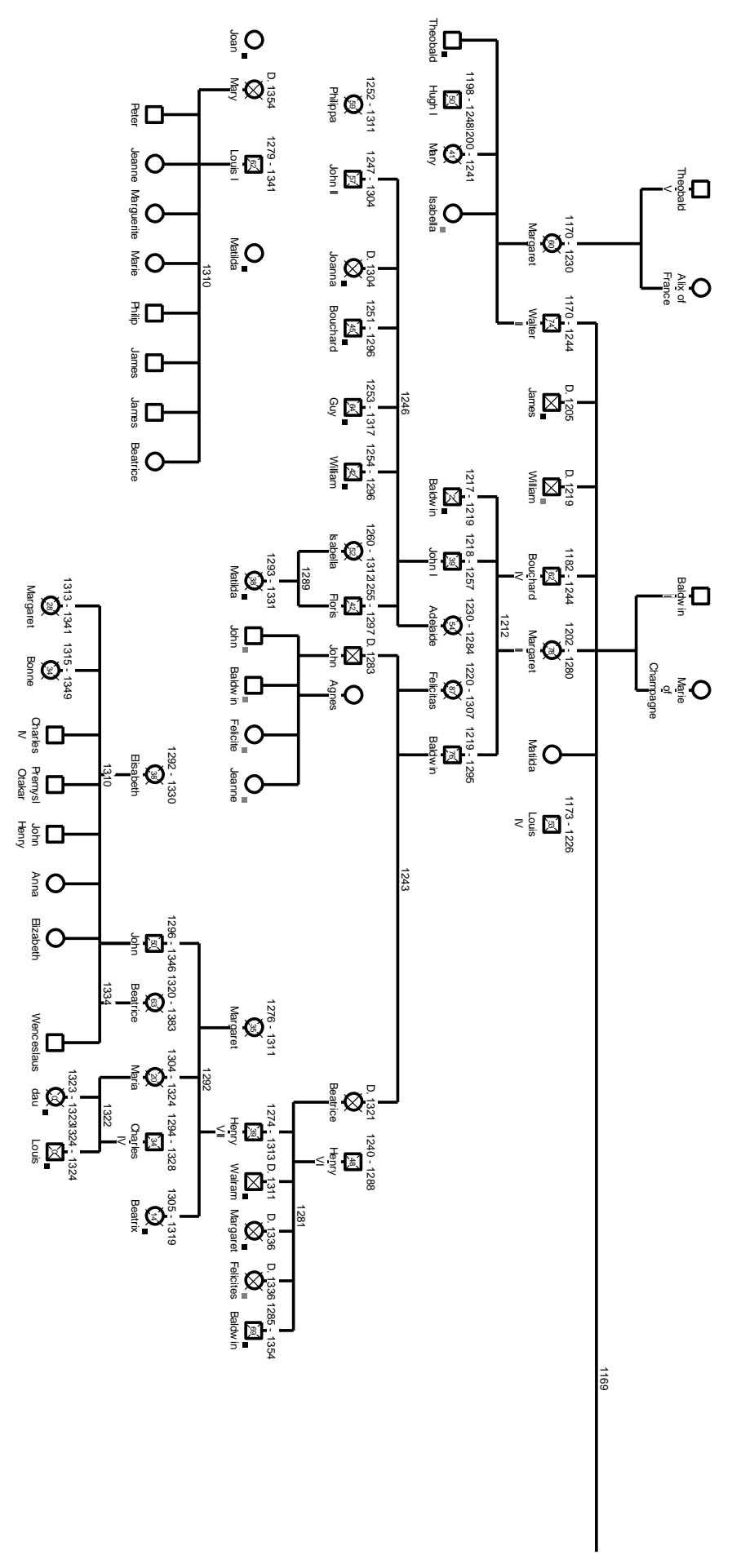


4.18c: Avesnes genealogy chart created by author in Geno Pro

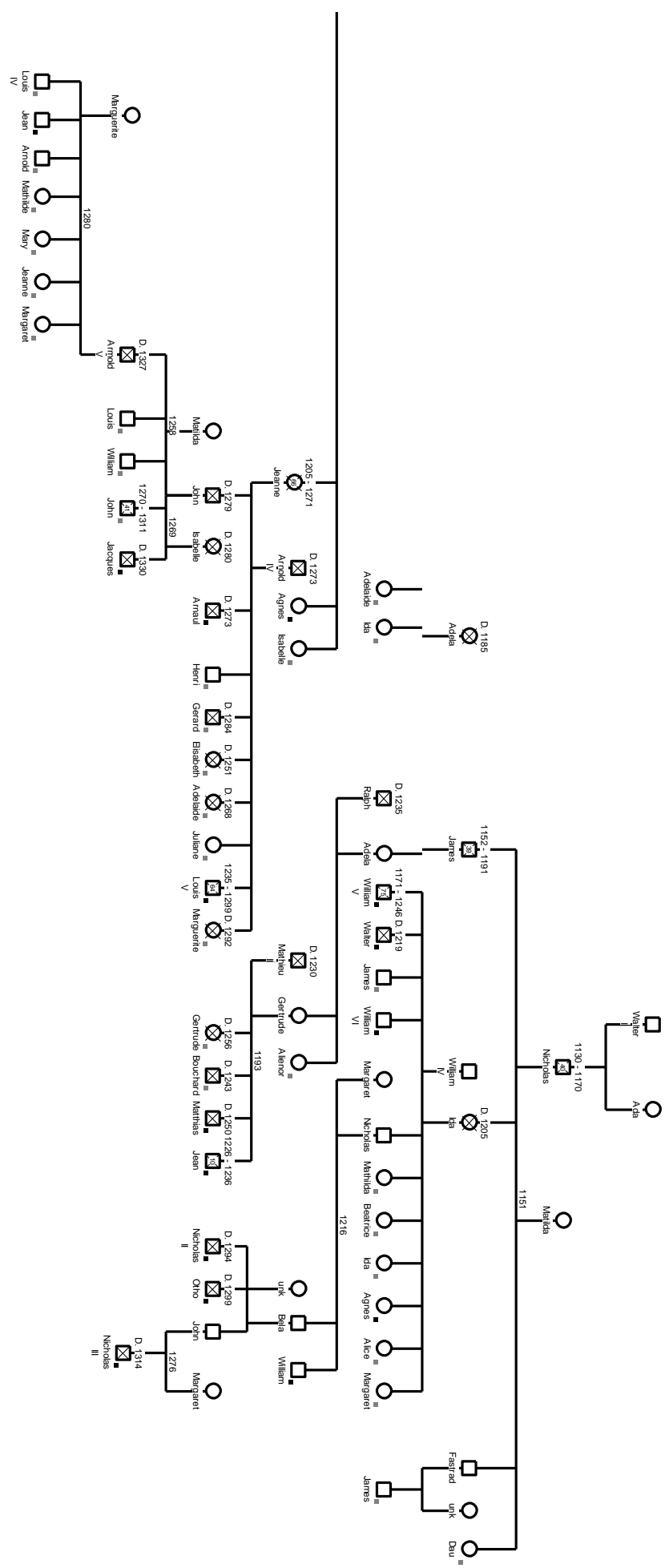




\section{The Earls of Northumbria}

The family had its origins in Scandinavia. Siward was the first of the family to travel to England with Cnut, King of Denmark and King of Norway. During the reign of Cnut, the Earls of Northumbria became one of the most important Anglo-Danish families in England. The first member of the family in this sample was Waltheof. He held the title the Earl of Northumbria, a title he inherited from his father at a young age. Because of his age, King Edward the Confessor appointed Tostig Godwinson, son of Earl Godwin and discussed earlier as the husband of Judith of Flanders, to maintain the earldom. The title was restored in 1065 which gave Waltheof control of Northamptonshire and Huntingdonshire. He married Judith de Lens, the daughter of Lambert II, Count of Lens and Adelaide of Normandy, Countess of Aumale (Adelaide was the sister of William the Conqueror). Judith was a wealthy heiress, having land in ten counties throughout the Midlands and East Anglia including Northamptonshire, Leicestershire, Oxfordshire, Bedfordshire, and Huntingdonshire (Domesday Book). Her uncle William I attempted to arrange her marriage to Simon de Senlis but she refused. The fact that Judith was a wealthy heiress gave her more say in her marriage choice than most noble women who were not as wealthy. Years later, her daughter Maud would marry Simon.

Walethof and Maud's daughter, Maud, married twice: first to Simon de Senlis Earl of Huntingdon-Northampton and second to David I King of Scotland. She brought the earldom of Huntingdon as her dowry, which included much of the eastern part of England. She also gained the title Queen of Scots. The eldest son of Maud and Simon de Senlis, another Simon, would be a prominent figure in the Anarchy, fighting on the side 
of Stephen of England. He would marry Isabel, daughter of Robert de Beaumont $2^{\text {nd }}$ Earl of Leicester and a member of the powerful Beaumont family discussed earlier.

Another daughter of Waltheof and Judith of Lens, Adelsie, married Raoul III of Tosny, an Anglo-Norman member of the nobility, whose family was rewarded with the baronies of Flamstead in Hertfordshire and Wrethemthorpe in Norfolk in addition to lands in Normandy. In 1075, Waltheof would take part in the Revolt of the Earls against William I. He would ultimately lose his head as part of the rebellion.

Table 4.11. Northumbria family demographics.

\begin{tabular}{lc}
\hline Variable & $N$ \\
\hline Generations & 11 \\
Individuals in sample & 926 \\
Males & 480 \\
Females & 446 \\
Progeny of Progenitor & \\
Total Children & 3 \\
Sons & 1 \\
Daughters & 2 \\
Total Grandchildren & 9 \\
Grandsons & 6 \\
Granddaughters & 3 \\
Total Great-grandchildren & 9 \\
Great-Grandsons & 4 \\
Great-Granddaughters & 5 \\
Total Great-great-grandchildren & 34 \\
Great-Great-Grandsons & 16 \\
Great-Great-Granddaughters & 18 \\
\hline
\end{tabular}




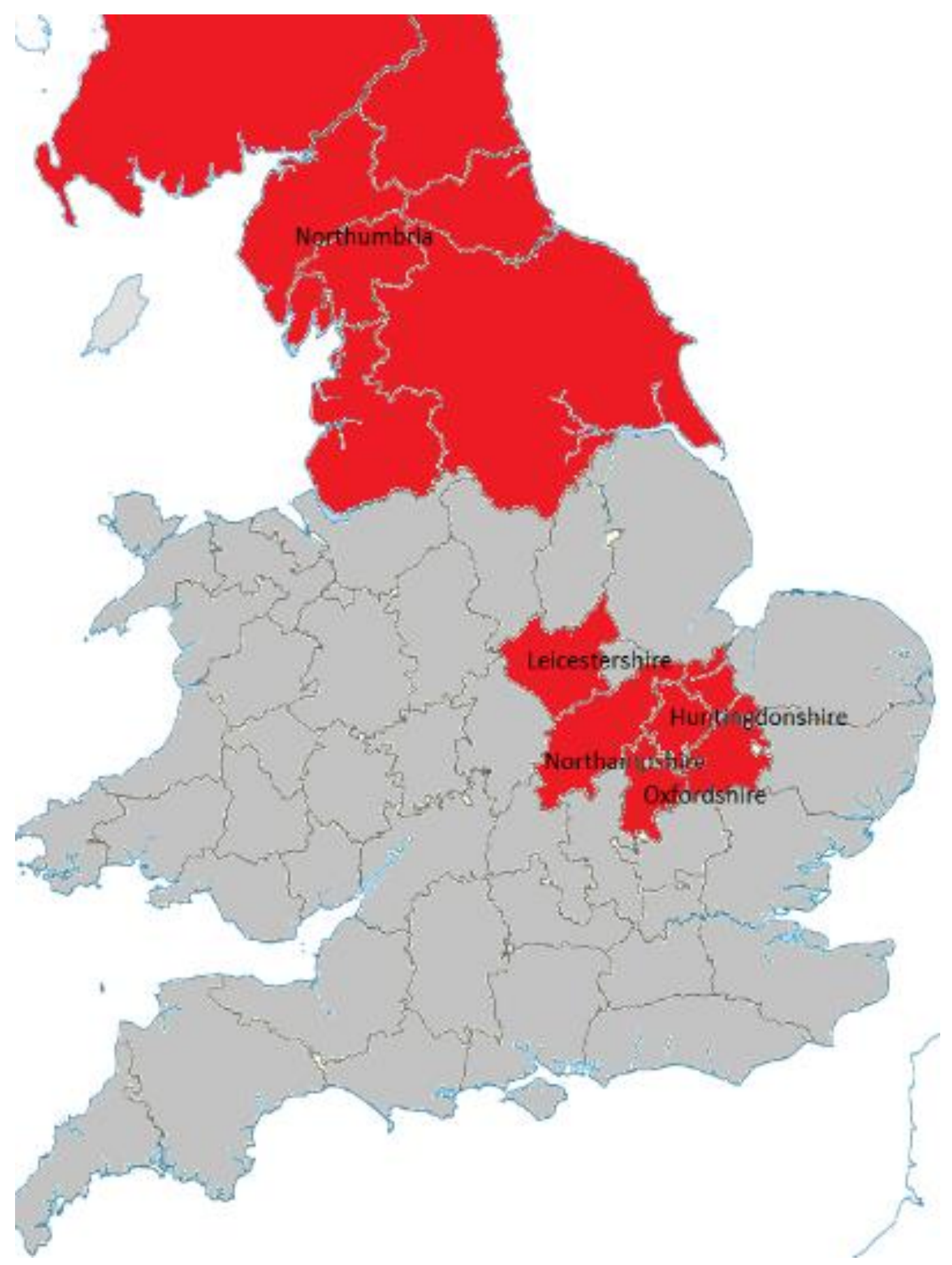

Figure 4.19: Earls of Northumbria land in England Adapted from: https://www.ancient.eu/image/9474/map-of-domesday-book-circuits/ 


\section{The Flanders family}

Baldwin II is the first in the Flanders cohort. He was the son of Arnulf III, Count of Boulogne. Upon his father's death in 990 he inherited the title Count of Boulogne. Baldwin married Adelina of Holland, the daughter of Arnulf Count of Holland and Lutgardis of Luxemburg. In 1022, Baldwin and his son Eustace joined with other French nobles and Robert II, King of France against the powerful Count of Blois, Odo II and Enguerrand I, Count of Ponthieu. Ultimately this alliance disintegrated and Baldwin was killed in battle. After Baldwin's death, Enguerrand married his wife, Adelina.

Baldwin's son Eustace succeeded him as the Count of Boulogne. Eustace would marry Matilda of Leuven, a direct maternal descendant of Charlemagne. Through another marriage alliance Eustace II, son of Eustace I and Matilda, married Goda, daughter of Æthelred the Unready and Emma of Normandy, and the sister of Edward the Confessor. She was also the niece of Richard II Duke of Normandy (grandfather of William the Conqueror). This marriage had far-reaching political implications in both England and France. However, this marriage was childless and after Goda's death, Eustace II would go on to marry Ida of Lorraine, daughter of Godfrey III, Duke of Lower Lorraine. Eustace II and Ida would have three sons, all of whom participated in the First Crusade and held important political positions (Count of Boulogne, Defender of the Holy Sepulcher of Jerusalem, and the King of Jerusalem) in France and Palestine. The Counts of Boulogne would become powerful members of the French aristocracy. The Flanders family had 601 individuals included in the sample. The progenitor of the sample population, Baldwin and his wife Adelina of Holland had a small number of descendants but successive generations of the family were much more successful (Tanner 1991). 
Table 4.12. Flanders family demographics.

\begin{tabular}{lc}
\hline Variable & $N$ \\
\hline Generations & 11 \\
Individuals in sample & 598 \\
Males & 278 \\
Females & 320 \\
Progeny of Progenitor & \\
Total Children & 1 \\
$\quad$ Sons & 1 \\
Daughters & 0 \\
Total Grandchildren & 4 \\
Grandsons & 3 \\
Granddaughters & 1 \\
Total Great-grandchildren & 5 \\
Great-Grandsons & 3 \\
$\quad$ Great-Granddaughters & 2 \\
Total Great-great-grandchildren & 5 \\
Great-Great-Grandsons & 1 \\
Great-Great-Granddaughters & 3 \\
\hline
\end{tabular}




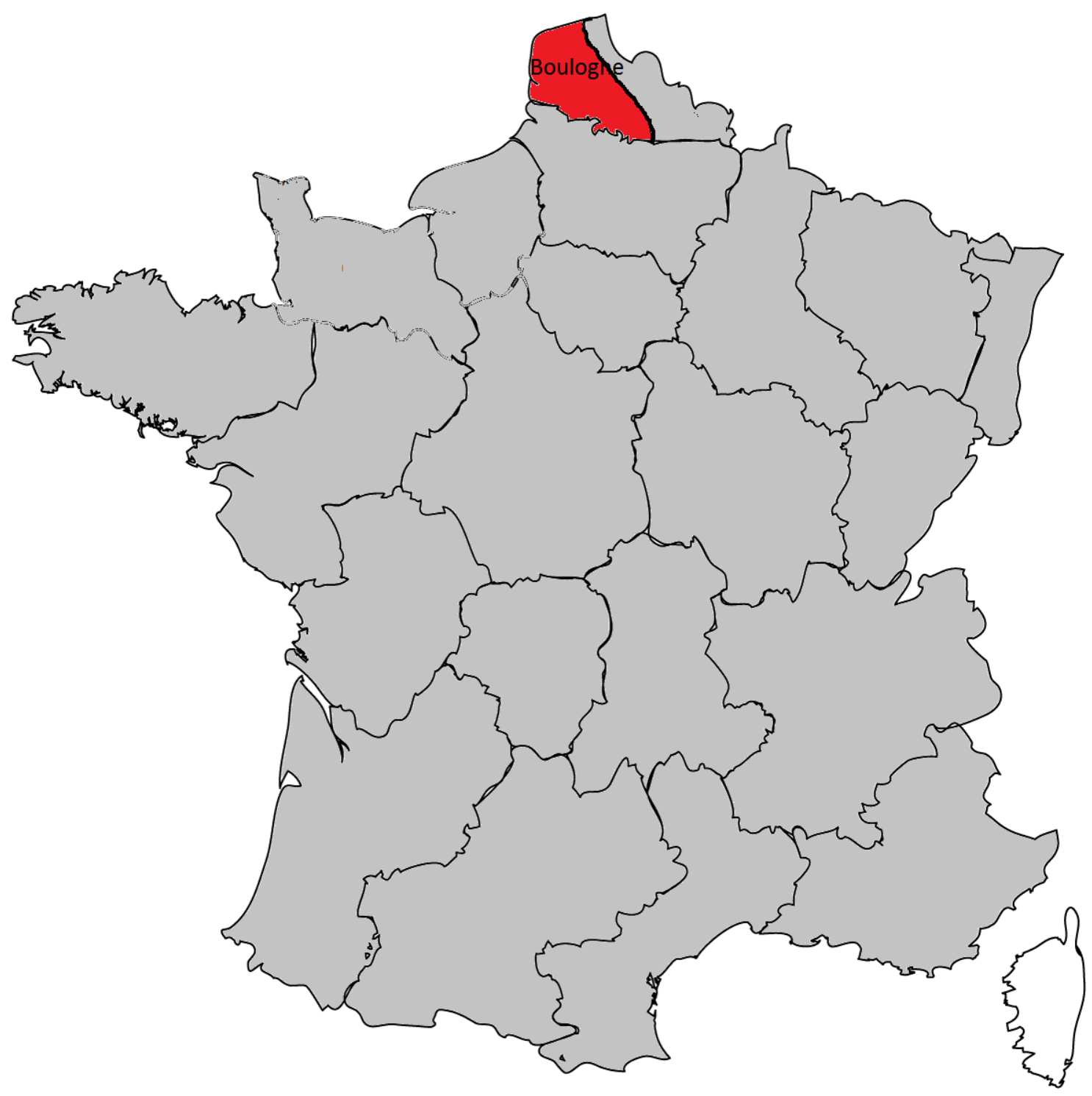

Figure 4.20: Flanders land in France

Adapted from:https://www.chateauxpourtous.fr/france-1-medieval-homes-houses-withdungeon-for-sale-in-France-medieval-castles-ruins-for-sale.php 


\section{The House of Reginar}

The House of Reginar was a large family that was located primarily in the Duchies of Lower Lorraine and Brabant. Members of the house would hold multiple titles including the positions of duke, landgrave, margrave, and count. The first of the House of Reginar, in the database, is Lambert I, Count of Louvain. He was the son of Reginar III, Count of Hainaut and Adela d'Eguisheim. Lambert and his wife Gerberga of Lower Lorraine (granddaughter of Louis IV, King of West Francia) produced five children. Their only daughter, Matilda, married Eustace I of Boulogne the son of Baldwin II Count of Boulogne and Adelina of Holland (discussed above in under the Flanders family). Their first son, Eustace, was married to Goda, the daughter of King Æthelred the Unready. The second son of Matilda and Eustace, Lambert II Count of Lens, fathered Judith of Lens. As her father's only child, she was a wealthy heiress and was later married to Waltheof $1^{\text {st }}$ Earl of Northampton (discussed above with the House of Northumbria). Their (Judith and Waltheof's) daughter, Maud, became the Queen Consort of Scotland through her marriage to David I, King of Scotland. The House of Reginar, had close ties to the House of Flanders and House of Northumbria, as well as several other aristocratic families. 


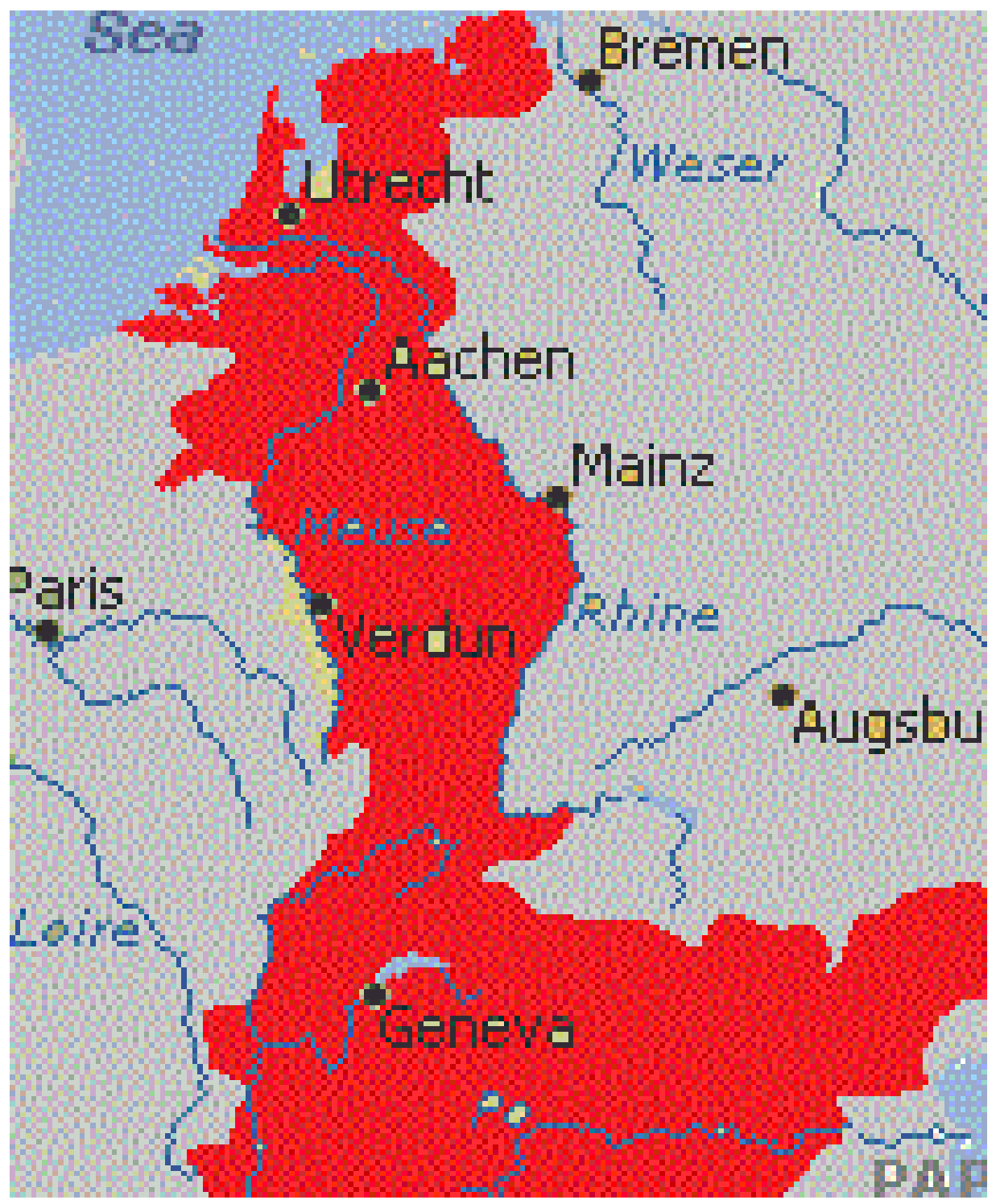

Figure 4.21: Reginar lands

Adapted from: https://sites.google.com/site/medievalcatholicism/1-post-carolingianfrance-2-crusades 
Table 4.13. Reginar family demographics

\begin{tabular}{lr}
\hline Variable & $N$ \\
\hline Generations & 6 \\
Individuals in sample & 427 \\
Males & 248 \\
Females & 179 \\
Progeny of Progenitor & 5 \\
Total Children & 4 \\
$\quad$ Sons & 1 \\
Daughters & 10 \\
Total Grandchildren & 6 \\
Grandsons & 4 \\
Granddaughters & 12 \\
Total Great-grandchildren & 6 \\
Great-Grandsons & 6 \\
Great-Granddaughters & 28 \\
Total Great-great-grandchildren & 15 \\
Great-Great-Grandsons & 13 \\
Great-Great-Granddaughters &
\end{tabular}

\section{The Giffard family}

The Giffard family were members of the Norman aristocracy. The originator of the Giffard family, in the sample, was Walter, the son of Osborne de Bolbec and Avelina. Through his mother, Avelina a sister of Gunnor Duchess of Normandy, Walter Giffard was a second cousin, once removed, of William the Conqueror. Giffard was as staunch supporter of William and was present at the Council of Lillebonne. He provided ships to be used in the invasion of England in 1066. He was also one of the fifteen known companions of William at the Battle of Hastings. As a reward for his support he was given the feudal barony of Long Credon in Buckinghamshire. This grant included 107 manors in all (Sanders 1960). Walter Giffard and his wife Ermengarde, daughter of Gerard Flaitel, a Norman baron who held several substantial estates, produced three children (two sons, one daughter). The eldest son, another Walter inherited his father's land and increased the family's landholding throughout his tenure. 


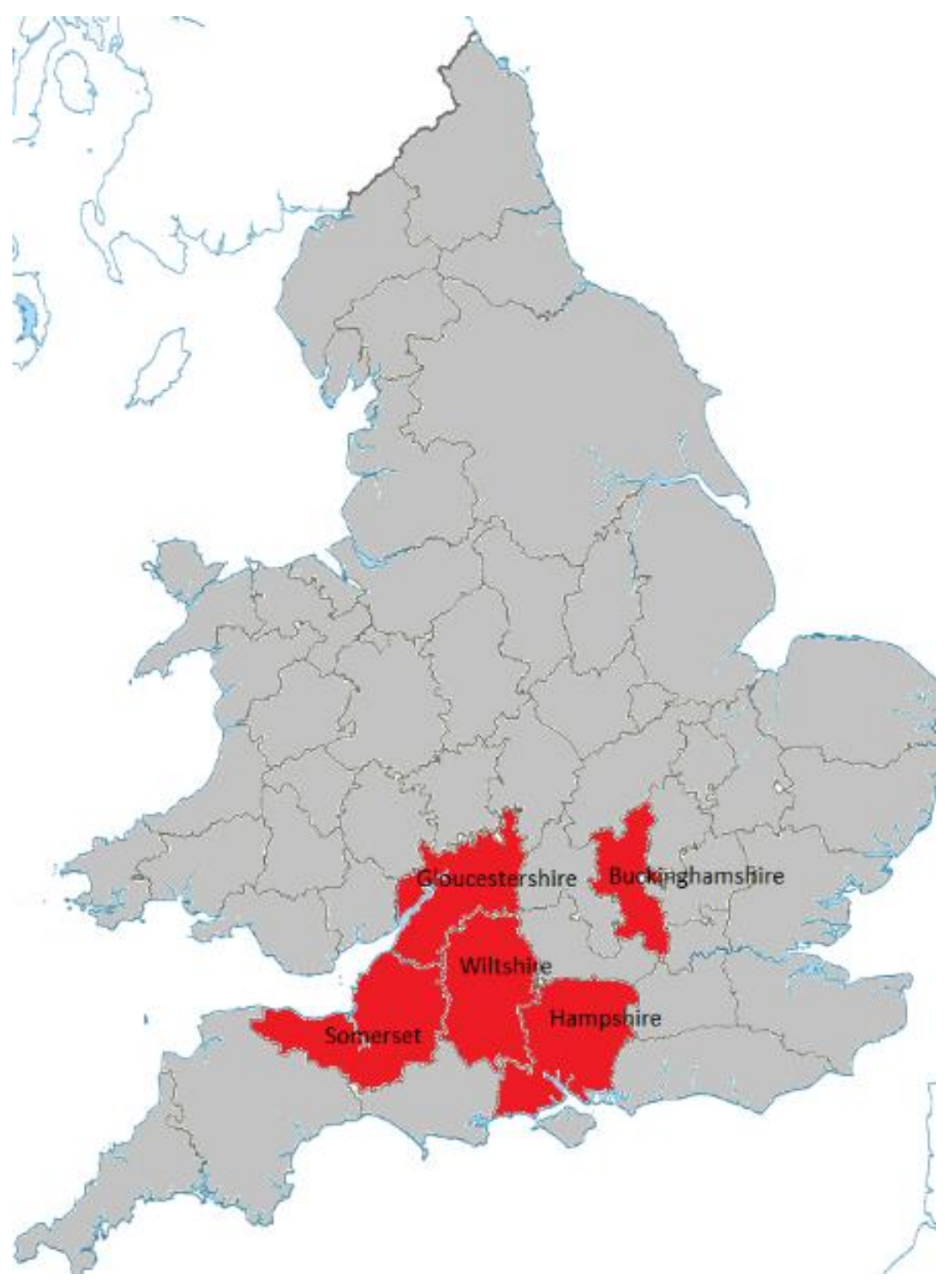

Figure 4.22: Giffard lands in England Adapted from: https://www.ancient.eu/image/9474/map-of-domesday-book-circuits/ 
This Walter was also created the $1^{\text {st }}$ Earl of Buckingham. The second son joined the Church and became the Bishop of Winchester during the reign of Henry I, King of England. The only daughter of Walter Giffard and his wife, Ermengarde, Rohese married Richard fitzGilbert, Lord of Clare, a member of the powerful de Clare family. This marriage produced at least six sons and two daughters. The male Giffard line went extinct in the third generation, so the descendants of Rohese Giffard and her husband would make up the bulk of this family's sample in the database.

Table 4.14. Giffard family demographics

\begin{tabular}{lc}
\hline Variable & $N$ \\
\hline Generations & 11 \\
Individuals in sample & 352 \\
Males & 191 \\
Females & 161 \\
Progeny of Progenitor & \\
Total Children & 4 \\
Sons & 2 \\
Daughters & 2 \\
Total Grandchildren & 9 \\
Grandsons & 7 \\
Granddaughters & 2 \\
Total Great-grandchildren & 11 \\
Great-Grandsons & 6 \\
Great-Granddaughters & 5 \\
Total Great-great-grandchildren & 26 \\
Great-Great-Grandsons & 13 \\
Great-Great-Granddaughters & 13 \\
\hline
\end{tabular}

\section{The de Clare family}

The de Clare's were a prominent family in both medieval France and England. The first recorded member of the family was Godfrey, Count of Eu. He was an illegitimate son of Richard I of Normandy, Count of Rouen. His grandsons would accompany William the Conqueror, their distant cousin, in the Norman invasion. The 
family would be greatly rewarded for their support with one son receiving control over 170 estates in Suffolk and the other the title of Sheriff of Devonshire.

The de Clare's would figure prominently in English politics. Gilbert and Roger de Clare, sons of Richard de Clare, the Norman knight, were present at the death of William II in 1100 and their sister was married to Walter Tyrol, William II's murderer. A de Clare was one of the sureties of the Magna Carta in 1215. Another Gilbert became the Earl of Pembroke holding lands in Ireland and Wales in addition to the massive English territories held. By the thirteenth century, the de Clare's were one of the wealthiest families in England, with estates in twenty-two English Counties, Wales, and Ireland, holding the titles to the Earldoms of Hertford, and Gloucester (England), and Pembroke (Wales), the Lordships of Striguil, and Glamorgan (Wales), and Thomond (Ireland), and the Barony of FitzWalter (England). Successive generations would marry into several of the most powerful families in England, including the Marshal, Bigod, Brus, Percy, Redvers, de Vere, and Plantagenet. 


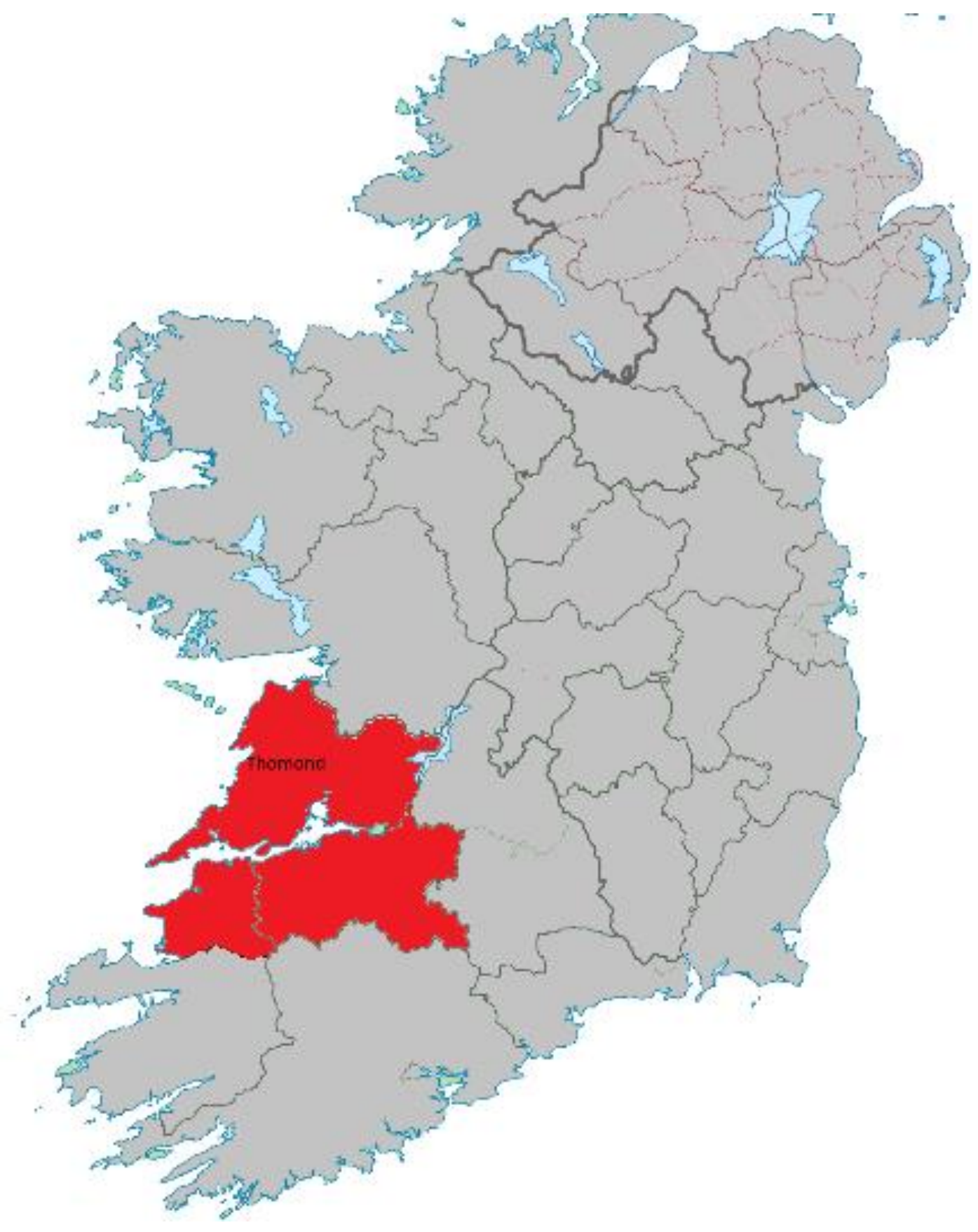

Figure 4.24: de Clare lands in Ireland

Adapted from: https://www.uni-due.de/IERC/IERC_Overview.htm 
Table 4.15. de Clare family demographics

\begin{tabular}{lr}
\hline Variable & $N$ \\
\hline Generations & 8 \\
Individuals in sample & 756 \\
Males & 416 \\
Females & 340 \\
Progeny of Progenitor & 1 \\
Total Children & 1 \\
Sons & 0 \\
Daughters & 4 \\
Total Grandchildren & 3 \\
Grandsons & 1 \\
Granddaughters & 13 \\
Total Great-grandchildren & 8 \\
Great-Grandsons & 5 \\
Great-Granddaughters & 11 \\
Total Great-great-grandchildren & 6 \\
Great-Great-Grandsons & 5 \\
Great-Great-Granddaughters &
\end{tabular}




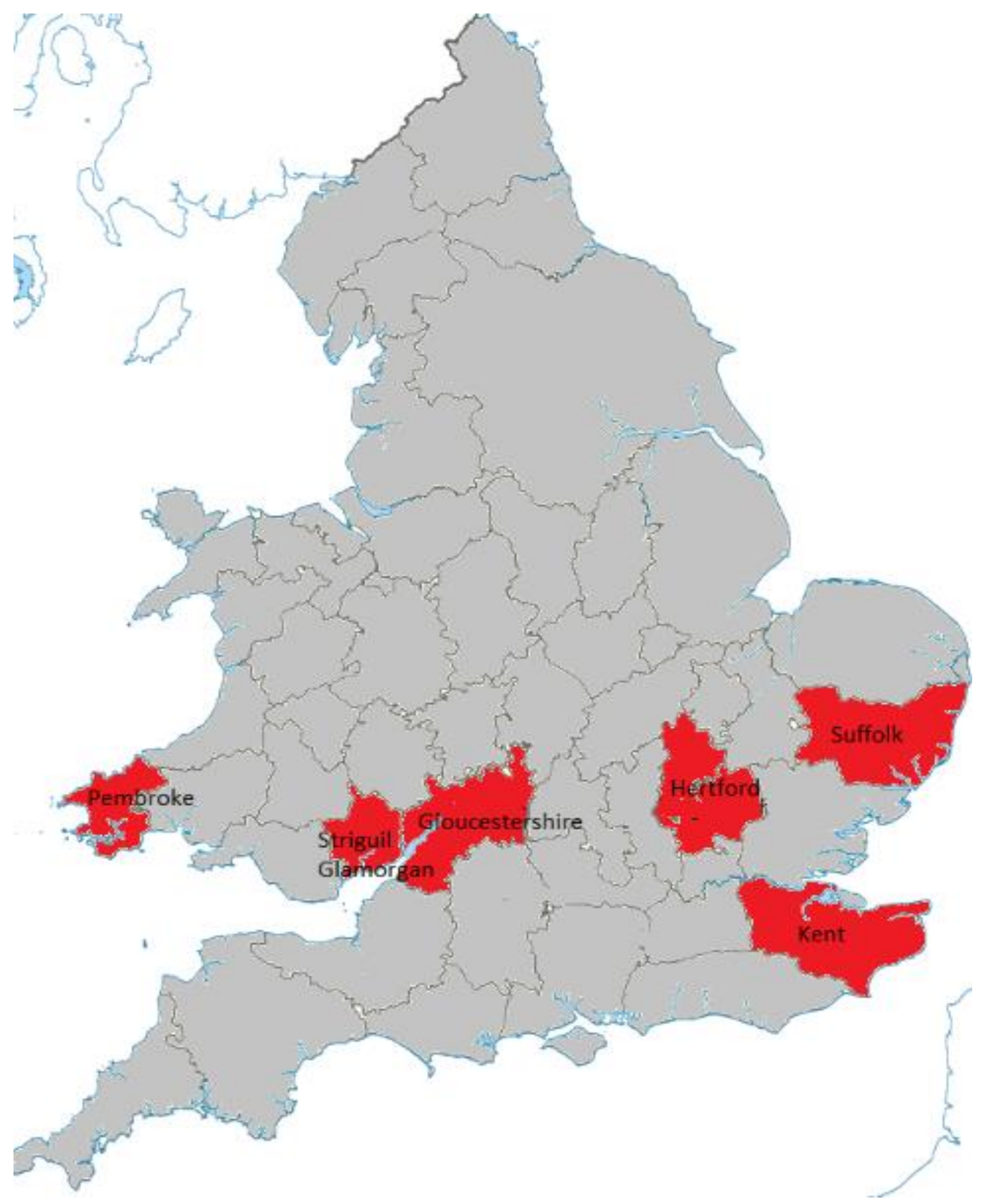

Figure 4.23 de Clare lands in England Adapted from: https://www.ancient.eu/image/9474/map-of-domesday-book-circuits/ 


\section{Chapter Five: Methods}

\section{Introduction}

The French and English aristocracy of the eleventh, twelfth, and thirteenth centuries provide a unique opportunity in which to examine hypotheses pertaining to differential parental investment. The aristocracies of Europe and specifically the French and English aristocracies were closed populations, in the sense that strict rules governed accessibility, marriage, and inheritance. Only select individuals were allowed to marry into the wealthiest families. This results in a microcosm population in which to examine the varying amounts of parental investment children will receive. Children are not invested in equally; birth order and gender impact the amount and type of investment a child receives from its parents. Sons will receive preferential treatment over daughters and older children will receive preferential treatment over younger born siblings (Hager 1992). Investment will also shift depending on the age of the child. As infants, males will receive heavy parental investment and females will receive less. As the child ages, the parents' focus may shift to greater investment in daughters over sons with a focus on securing an appropriate marriage for a daughter and providing a sufficient dowry.

\section{Study Population}

The study population in this dissertation consists of 15 individual families spanning multiple generations during the eleventh, twelfth, and thirteenth centuries. The earliest data were from the year 952 and the last data collected were from 1300. As many as 12 generations of data were collected with some families having more generations than others. This resulted in the collection of data for 10,515 individual family group sheets. However, as a result of consistent intermarriage within and between the families, many 
individuals were present in multiple families and in some cases multiple generations. To prevent errors in the statistical analysis, steps were taken to ensure that individuals were only listed in the database once. All individuals were given a unique code and it was noted if and when they appeared in the database more than once. If an individual was listed in the database under their mother and father, one entry was removed and they would be listed under the first parent. This resulted in an Excel database consisting of 2,509 individuals (1372 males and 1170 females). All data were verified on the family group sheets before being transferred to the database. To ensure accuracy, the data were entered into the database twice.

Eleven of the families were French in origin (L'Aigle, Bigod, de Montgomery, de Vere, Godwin, Welf, Beaumont, Avesnes, Flanders, Reginar, Giffard), but migrated to England with the Norman invasion in 1066 or shortly after and became some of the highest ranking members of the English aristocracy. The remaining four families were English/Scottish in origin (Marshal, Northumbria, de Clare, and Brus). See Table 5.1 below for database information. 
Table 5.1. Database Information

\begin{tabular}{lclcr}
\hline Family & Family Code & Origins & Total Generations & Total Individuals \\
\hline L'Aigle & 1 & French & 10 & 158 \\
Bigod & 2 & French & 5 & 59 \\
Brus & 3 & English & 8 & 31 \\
Godwin & 4 & French & 11 & 731 \\
Marshal & 5 & English & 5 & 55 \\
Welf & 6 & French & 7 & 118 \\
Montgomerie & 7 & French & 11 & 355 \\
Beaumont & 8 & French & 11 & 152 \\
de Vere & 9 & French & 7 & 34 \\
Avesnes & 10 & French & 7 & 84 \\
Northumbria & 11 & English & 11 & 299 \\
Flanders & 12 & French & 11 & 174 \\
Reginar & 13 & French & 6 & 65 \\
Giffard & 14 & French & 11 & 143 \\
de Clare & 15 & English & 8 & 51 \\
\hline
\end{tabular}

\section{Sources used for data collection}

I collected data on the focal population from a variety of sources. The initial data were collected from the Domesday Book which provided an account of the lands held by the Norman supporters of William the Conqueror as well high ranking English families. The Complete Peerage, or a History of the House of Lords and all its members from the earliest times edited by Hammond and Cokayne, as well as Elizabeth Rixford's Families Directly Descended from all the royal families in Europe (495 to 1932) and Mayflower Descendants, and Burke's Peerage $107^{\text {th }}$ edition were all used to collect genealogical data. Sanders (1960) English Baronies: A Study of their Origin and Descent 1086-1327 provided information on several English families. Online genealogical resources were also used for data collection. Once the original families had been identified, print sources on individual families were utilized. Due to the significant intermarriage both within and between the families in the sample, there was consistent overlap in the genealogical sources. 
Genealogical information on the first family in the sample, the L'Aigle family ( $\mathrm{n}=$ 845) was collected using Kathleen Turner's (1996) article The Lords of L'Aigle: Ambition and Insecurity on the borders of Normandy and her 2002 book Power and Border Lordship in Medieval France: the County of Perche, 1000-1226. Additional information about the members of the family was found in the sources relating to the Montgomery family as a result of intermarriage between the L'Aigle and Montgomery family.

Genealogical information on the Bigod family $(\mathrm{n}=28)$ was collected using The Motives and Politics of the Bigod Family, 1066-1177 (Wareham 1995) as well as Morris (2005) The Bigod Earls of Norfolk in the Thirteenth Century. Data were also collected from the sources for the L'Aigle, Montgomery, Beaumont, de Vere, Giffard, and de Clare families as several members of the Bigod family married into each of these noble families.

Material on the Brus family (Bruce) $(\mathrm{n}=74)$ was readily available in both print and online sources. Blakely (2005) Robert de Brus I: Founder of the Family and the online genealogical site familyofbruce.org were the main sources utilized, but information was also obtained through previously listed sources as members of the Brus family married into five of the other families (Bigod, Godwin, Marshal, Montgomery, and Northumbria).

The largest family group in the sample was the Godwin family $(\mathrm{n}=2422)$. Genealogical data for the Godwin family was collected using Mason (2004) The House of Godwin: The History of a Dynasty and Barlow (2013) The Godwins: The Rise and Fall of a Noble Dynasty. Resources were also utilized that focused on the Welf and Brus families as members of the Godwin family also took part in intermarriage with those families. 
Due to the importance of the Marshal family $(n=309)$, there are multiple sources that contain family history information. The main sources used were Crouch (2015) William Marshal: Knighthood, War, and Chivalry, 1147-1219 and Crouch (2016) The Acts and Letters of the Marshal Family: Marshals of England and Earls of Pembroke, 1145-1248. Additional information was obtained from other family genealogies as the descendants of William Marshal married into five of the other families included in the sample population (L’Aigle, Bigod, Brus, Montgomery, and Giffard families).

The Montgomery family was one of the larger families in the sample $(n=1271)$. Data were collected from Thompson (1987) The Norman Aristocracy before 1066: the example of the Montgomery's as well as from Mason (1963) Roger de Montgomery and his Sons (1067-1102). Multiple families from outside the focal population married into the Montgomery family such as the House of Belleme and the House of Lusignan. White (1940) The First House of Belleme and Painter (1955) The Houses of Lusignan and Chatellerault 1150-1250 were used to collect data on each house respectively.

Edward Beaumont's (1928) The Beaumonts in History: A.D. 850-1850, provided information on the specific Beaumont family $(n=353)$, as well as information on members of other families (L'Aigle, Marshal, Montgomery, Flanders, and Giffard) whose descendants married into the Beaumont family. Crouch (1986) The Beaumont Twins; the Roots and Branches of Power in the Twelfth Century provided additional genealogical information.

Genealogical information for the founding members of the Welf family $(n=1845)$ was collected primarily from Lyons (2013) Princely brothers and sisters: the sibling bond in German politics, 1100-1250. Like the Marshal family, the Welf family also 
married into several of the other families in the population sample (the Godwin, Montgomery, Northumbria, and Flanders families. When the main branch of the Welf family died out, one of the cadet branches continued to flourish in the form of the Flanders family (family \# 12 in the database).

The de Vere family $(n=83)$ had a relatively small number of members during the timeframe of this study, but was still one of the most influential. The de Vere's and their descendants married multiple times into the Bigod, Montgomery, Giffard, and de Clare families. Information was gathered from sources relating to these families as well as Anderson's (1993) The De Veres of Castle Hedingham. Information on the Avesnes family ( $\mathrm{n}=212)$ was collected using online databases as well as Evergates (2007) The Aristocracy in the County of Champagne, 1100-1300.

Information for the Northumbria family $(\mathrm{n}=928)$ was collected using Rollason (2003) Northumbria, 500-1100: Creation and Destruction of a Kingdom. Was used to gather basic background information on the family. The Northumbria family also married into the Brus and Flanders families so genealogical data was drawn from those families as well. The Flanders $(n=601)$ family was a cadet branch of the previously mentioned Welf family. Much of the data for the Flanders family was collected from previously mentioned sources. Information on both the Reginar family $(n=428)$ and the Giffard family ( $n=352)$ were collected largely from online genealogical databases as well as Hammond and Cokayne and Burke's Peerage.

Information was readily available on the de Clare family (n=764). Altschul (1965) A Baronial Family in Medieval England the Clares 1217-1314 provided some of the background information for the family. Cokayne was also used for successive generations 
of data collection. Ward (1988) was also used to better understand the relationship between the de Clare family and the crown.

\section{Data Collection}

Data were collected on multiple generations of each family beginning in 1000 and ending in 1300. Two families had the fewest number of generations at five. Four of the families had seven generations, two had eight generations, one family had ten generations represented, four included eleven generations, and one family had twelve generations. Family group sheets (see appendix 1 below) were compiled for each person within the database as well as genealogy charts that showed the complicated relationships between these 15 families (see Chapter 4 History of Focal Families for genealogy charts). These data were then used to construct an Excel spreadsheet. The end result was a database with 241 variables of information collected on each individual.

Demographic and life history data were collected and coded for the members of each family. The data started out with the basic dates of birth and death as well as the age at death. It was noted if the individual survived to the ages of 5 and 15 , represented by the codes $0=$ no, $1=$ yes, $3=$ unknown). The mortality of older siblings was also recorded (older brother/older sister died: $0=$ no, $1=$ yes, $3=$ unknown). If the individual died before their mother/father they were given a code of $1=$ yes and if they died after their parents they were assigned a code of $0=$ no.

Birth order was a key component in several hypotheses for this dissertation so, the general birth order was recorded for each member of the sample (from both the mother's and the father's perspective) and then their birth order based on their gender was noted. For example, it was possible for an individual to be the first born male from their 
mother's perspective, but her $5^{\text {th }}$ child overall. Two categories were created for birth order: first born $0=$ no, $1=$ yes and second born $0=$ no, $1=$ yes.

Information was also collected for each spouse. Their name and dates of birth and death were recorded. The names of their parents were also collected and family names were collected for the mother of each spouse. The birth order (overall and for each respective parent) of the spouse was documented. The age of the spouse at the death of their mother and father was noted. Marital data were also collected including the marriage date and location. The marriages for several members of the focal population ended either in annulment or divorce. This information was also collected and coded $(0=$ no, $1=$ annulment, $2=$ divorce $)$. The age at marriage was recorded for both spouses as was the age at their first birth. The age at first birth represented the birth of the first child to that specific couple. If one or both of the spouses had been married before, the age at first birth could vary.

The number of children born to each couple was included in the data entry. This was broken down into three categories: the number of children born, the number of sons born, and the number of daughters born. This was further divided into the number of children who survived (to age 5 and 15), the number of sons who survived to ages 5 and 15 and the number of daughters who survived to ages 5 and 15 . The total number of grandchildren, total number of grandsons, and the total number of granddaughters was documented. This was repeated for the number of great grandchildren and great-great grandchildren born.

Some individuals in the population were married as many as four times, so this process was repeated for each successive spouse. Basic demographic data were collected, 
but also the names of their parents, their respective birth order, marriage date, age at marriage, age at first birth, and the number of children, grandchildren, great grandchildren and great-great grandchildren born to the couple.

It was also noted in each marriage if the spouses were related to each other. Each individual received 2 codes, one to determine if they were related $(0=$ no, $1=y e s)$ and then the type of relation. If they were affinal kin they were given a code of 1 . If they were consanguineal kin they were given a code of 2 . A note was created for each couple that fell within either one of these categories explaining the type of relationship. For example, one couple from the Reginar family were affinal kin as a woman married her mother's third husband's son from a previous marriage. In another Reginar family example, a woman married, as her second husband, the step father of her first husband. In a third example found within the Marshal family, a woman's sister-in-law was also her older sister's mother-in-law. Consanguine relations were also noted, although the degree of consanguinity was not coded due to the complex system of intermarriage. A couple for example, could be double first cousins, first and second cousins, or even in some cases, second, third, and fourth cousins.

In addition to demographic data, information was also collected on the status of each individual as well as the overall status of the family. Status/wealth was determined in two ways: the number of titles held and the importance /significance of those titles. This information was entered into the database noting if a title was held $(0=$ no, $1=y e s)$, how many titles were held, the highest title and the years specific title was held. It was also recorded how the title was transferred with fourteen methods of transfer identified (See Table 5.2 below). 
Table 5.2: Methods of Title Transfer

\begin{tabular}{lc}
\hline Method of Transfer & Code \\
\hline Unknown & 0 \\
Father & 1 \\
Bestowed & 2 \\
Husband upon marriage & 3 \\
Jure uroxis & 4 \\
King & 5 \\
Brother & 6 \\
Sister & 7 \\
Cousin & 8 \\
Mother & 9 \\
Grandfather & 10 \\
Brother-in-law & 11 \\
Uncle & 12 \\
Nephew & 13 \\
\hline
\end{tabular}

*jure uroxis (in right of wife)

Each title was assigned a code, with 26 codes created. See Table 5.3 below for explanation of titles.

Table 5.3. Title Classification

\begin{tabular}{lc}
\hline Title Name & Title Code \\
\hline No title/unclear & 0 \\
King/Queen & 1 \\
Prince/Princess & 2 \\
Duke/Duchess & 3 \\
Baron/Baroness & 4 \\
Earl/Countess & 5 \\
Grand Duke & 6 \\
Count/Countess & 7 \\
Lord/Lady & 8 \\
Emperor/Empress & 9 \\
Margrave/Margravine & 10 \\
Landgravine/Landgravine & 11 \\
Law & 12 \\
Viscount/Viscountess & 13 \\
Regent & 14 \\
Marquis/Marchioness & 15 \\
Sire & 16 \\
Knight & 17 \\
\hline
\end{tabular}


Table 5.3. Title Classification continued.

\begin{tabular}{lc}
\hline Title Name & Title Code \\
\hline Royal Household & 18 \\
Grand Prince & 19 \\
Jarl & 20 \\
Burgrave/Burgravine & 21 \\
Count Palatine & 22 \\
Patriarch & 23 \\
Governor & 24 \\
Elector Palatine & 25 \\
\hline
\end{tabular}

The estate size of each individual was divided into four broad categories, no estate $=0$, small estate $=1$, large estate $=2$ and grandiose estate $=3$. Most individuals were placed within the small estate size based on titles alone (Earl, Lord, Baron, Count, Margrave, Landgrave, Viscount, Marquis, Sire, Knight, royal household, Burgrave, Count Palatine, Governor, Elector Palatine and their feminine equivalents). Titles associated with the large estates were King, Prince, Emperor, Regent, and Duke and the female equivalents. Individuals were placed in the third category (grandiose) if they were a king of a significant kingdom (England, France, Spain, in comparison to German kingdoms such as Wittelsbach and if they yielded significant power. For example, John I, King of England was given a code of 2, while Sancho II King of Portugal was given a code of 3 . However, title alone could not determine the amount of influence the individual wielded. William Marshal, for example was the $1^{\text {st }}$ Earl of Pembroke and by the previously stated estate categories would be categorized as holding a small estate. His influence however, was much greater having served five English kings. He was also the ancestor of the Bruce and Stewart Scottish kings as well as the last Plantagenet king Edward IV and all of the English monarchs from Henry VIII.

The amount of land was noted as well as the date of acquisition, the method of transfer, and the location of the property. This also included an examination of the size of 
dowries transferred from one family to another. This information was not specifically coded and entered into the database, but it was noted on the individual family group sheets. The occupation for each member in the database was coded as $0=$ no occupation, reserved for those who died young, $1=$ secular occupation, and 2=non-secular occupation. In addition to secular titles, data were also collected on religious titles as well. A code was created to denote whether or not the individual entered the church $(0=$ no, 1=yes). Nineteen different Church related titles or activities were identified and coded (see Table 5.4 below).

Table 5.4. Church related titles

\begin{tabular}{lc}
\hline Title Name & Title Code \\
\hline No title/unclear & 0 \\
Abbott & 1 \\
Abbess/Prioress & 2 \\
Monk & 3 \\
Nun & 4 \\
Bishop & 5 \\
Archbishop & 6 \\
Pope & 7 \\
Priest & 8 \\
Saint & 9 \\
Rector & 10 \\
Dean/Provost & 11 \\
Prior & 12 \\
Archdeacon & 13 \\
Novice & 14 \\
Canon & 15 \\
Patriarch & 16 \\
Friar & 17 \\
Teutonic Order & 18 \\
Knights Templar & 19 \\
\hline
\end{tabular}

If an individual did enter the church, it was also determined if they attained high rank $(0=$ no, 1=yes).high rank was classified as Abbot, Abbess/Prioress, Bishop, Archbishop, Pope, Saint, Dean, and Provost, Archdeacon and Canon. The rank of monk, 
nun, priest, prior, and novice were all classified as lesser church titles. Specific appointments/titles were documented including the date the position was held and with which monastery, convent or parish church. This specific information was not coded for the database, but it was noted on the individual group sheet.

The cause of death for each individual was also recorded if known. This information may be used for additional research in the future. Ten codes were created to represent the cause of death. If the cause of death was unknown, the individual was given a code of 0 . There were multiple examples of women dying in childbirth (code of 1). Those who died in battle were assigned a code of 2 . If the death was an accident it received a 3. If the individual was assassinated they were given a code of 4. Stillborns were given a code of 5 . If the cause of death was illness, they received a 6 . Several individuals were executed (code of 7), murdered (code of 8), or died in captivity (code of 9).

The final piece of information that was collected related to burial location. I originally collected this data as a measure of social status. If they received a church burial I associated that with wealth. As the data collection continued it became apparent that the majority of the elite had some type of church burial. Despite this, I continued to collect the data creating a code for church burial $(0=$ no, $1=y e s)$. The actual location was also recorded in the database.

\section{Variables}

The main dependent variable used for child survival was binary. Did the child survive to age $5(0=$ no, $1=$ yes $)$ and to age $15(0=$ no, $1=$ yes $)$. In the sample 2,119 children survived to the age of 5 and 223 did not (unknown $N=167$ ). The number surviving to age 
15 was 2,072 with 329 not surviving to that age (unknown $N=108$ ). In these analyses, died before mother was used as one of the controls ( $0=$ no, $1=y e s)$. There were 1,222 individuals that died before their mother, with 430 dying after their mother (unknown $N$ =857). As will be discussed in greater detail, birth dates were difficult to obtain for a portion of the population resulting in this unknown data. Another control was historical time period with the data being divided into 4 categories (Time period 1:1000-1066 $(N=64)$, Time period 2:1066-1154 $(N=298)$, Time period 3:1155-1216 $(N=578)$, and Time period 4:1216-1300 $(N=1578)$. Country code was also used to separate the data (1=England $(N=2073), 2=$ France $(N=436)$ and control for the location of the individuals in the sample.

The dependent variables used to analyze parental investment were binary and ordinal. The data were first divided by sex $($ males $=1338$, females $=1169)$. In determining parental investment, number of titles, highest title, entry into Church $(0=$ no $N=2298,1=$ yes $N=205)$, attaining high rank in the Church $(0=$ no $(N=2391), 1=$ yes $(\mathrm{N}=$ $117)$, and estate size $(4$ categories: $0=$ unknown $(N=905), 1=$ small $(N=1461), 2=$ large $(N=125)$, and $3=$ grandiose $(N=17))$ were all used as dependent variables. The predictors used in these analyses included birth order (first born $(N=632)$, second born $(N=491)$, and third born and above $(N=1375)$. Control variables included died before father $(0=$ no $(N=1470), 1=$ yes $(N=359)$ unknown $(N=680)$, historical time periods, and country code.

In analyzing marriage (consanguineal and affinal) multinomial and binary dependent variables were used. The data were divided by sex (males $=1338$, females $=$ 1169). The dependent variables were relatedness $(0=$ no relation $(\mathrm{N}=2351), 1=$ affinal $(\mathrm{N}=41), 2=$ consanguineal $(\mathrm{N}=116))$. The independent variables were related to birth 
order, while controls were died before father, country code, and historical time period. In the second part of the analysis the dependent variable was age of spouse, 5+ years older, $(0=$ no $(N=239), 1=$ yes $(N=423)$, unknown $(N=1847)$.

In the final set of analyses, the dependent variables were linear. The dependent variables were the number of children $(N=4,665$ [sons $N=2,407$, daughters $N=2,192])$, grandchildren $(N=7,883$ [sons $N=4,070$, daughters $N=3,707])$, great-grandchildren $N=13,158$ [sons $N=6,768$, daughters $N=6,239]$ ), and great-great grandchildren born ( $N=21,634$ [sons $N=11,201$, daughters $N=10,433]$ ). The data were divided by sex (males $N=1338$ and females $N=1169)$ and birth order (first born, $(N=632)$, second born, $(N=491)$, third born and up $(N=1375))$. See Table 5.5 Table for summary statistics of categorical variables used in this dissertation. Table 5.6 contains the summary statistics for continuous variables. 
Table 5.5. Summary statistics for categorical variables.

\begin{tabular}{|c|c|c|}
\hline Variable & $N$ & Percentage \\
\hline \multicolumn{3}{|l|}{$\overline{\text { Gender }}$} \\
\hline Males & 1338 & 53.3 \\
\hline Females & 1169 & 46.6 \\
\hline \multicolumn{3}{|l|}{ Birth order } \\
\hline First born & 632 & 25.2 \\
\hline Males & 399 & 29.8 \\
\hline Females & 233 & 19.9 \\
\hline Second born & 491 & 19.6 \\
\hline Males & 300 & 22.4 \\
\hline Females & 191 & 1.3 \\
\hline Birth order 3 and up & 1375 & 54.8 \\
\hline Males & 632 & 47.2 \\
\hline Females & 741 & 63.4 \\
\hline \multicolumn{3}{|l|}{ Historical Time Period } \\
\hline $\bar{T}$ Time period 1 (1000-1066) & 64 & 2.6 \\
\hline Time period 2: (1066-1154) & 289 & 11.5 \\
\hline Time period 3: (1155-1216) & 578 & 23.0 \\
\hline Time period 4: (1216-1300) & 1578 & 62.9 \\
\hline \multicolumn{3}{|l|}{ Country code } \\
\hline England (1) & 2073 & 82.6 \\
\hline France (2) & 436 & 17.4 \\
\hline \multicolumn{3}{|l|}{ Survival } \\
\hline Survived to age 5 & 2119 & 84.5 \\
\hline Males & 1100 & 82.2 \\
\hline Females & 1019 & 87.2 \\
\hline Did not survive to age 5 & 223 & 8.9 \\
\hline Males & 137 & 10.2 \\
\hline Females & 84 & 7.2 \\
\hline Survived to age 15 & 2072 & 82.6 \\
\hline Males & 1068 & 79.8 \\
\hline Females & 1004 & 85.9 \\
\hline Did not survive to age 15 & 329 & 13.1 \\
\hline Males & 205 & 15.3 \\
\hline Females & 122 & 10.4 \\
\hline \multicolumn{3}{|l|}{ Died before mother } \\
\hline $0=$ no & 1204 & 48.0 \\
\hline Males & 654 & 48.9 \\
\hline Females & 550 & 47.0 \\
\hline
\end{tabular}


Table 5.5. Summary statistics for categorical variables continued.

\begin{tabular}{|c|c|c|}
\hline Variable & $N$ & Percentage \\
\hline \multicolumn{3}{|c|}{ Died before mother cont. } \\
\hline $1=$ yes & 434 & 17.3 \\
\hline Males & 266 & 19.9 \\
\hline Females & 166 & 14.2 \\
\hline Unknown & 870 & 34.7 \\
\hline Males & 416 & 31.1 \\
\hline Females & 453 & 38.8 \\
\hline \multicolumn{3}{|l|}{ Died before father } \\
\hline \multicolumn{3}{|l|}{$0=$ no } \\
\hline Males & 1454 & 58.0 \\
\hline Females & 820 & 61.3 \\
\hline $1=$ yes & 360 & 14.3 \\
\hline Males & 218 & 16.3 \\
\hline Females & 140 & 12.0 \\
\hline Unknown & 691 & 27.1 \\
\hline Males & 297 & 22.2 \\
\hline Females & 393 & 33.6 \\
\hline \multicolumn{3}{|l|}{ Noble titles } \\
\hline $0=$ None & 1150 & 45.9 \\
\hline Males & 589 & 44.1 \\
\hline Females & 559 & 47.8 \\
\hline 1 = King/Queen & 214 & 8.5 \\
\hline Males & 114 & 8.5 \\
\hline Females & 100 & 8.5 \\
\hline $2=$ Prince $/$ Princess & 48 & 1.9 \\
\hline Males & 35 & 2.6 \\
\hline Females & 13 & 1.1 \\
\hline $3=$ Duke/Duchess & 243 & 9.7 \\
\hline Males & 145 & 10.8 \\
\hline Females & 98 & 8.4 \\
\hline $4=$ Baron $/$ Baroness & 50 & 2.0 \\
\hline Males & 23 & 1.7 \\
\hline Females & 27 & 2.3 \\
\hline $5=$ Earl $/$ Countess & 166 & 6.6 \\
\hline Males & 98 & 7.3 \\
\hline Females & 68 & 5.8 \\
\hline $6=$ Grand Duke & 2 & 0.1 \\
\hline Males & 1 & 0.1 \\
\hline Females & 1 & 0.1 \\
\hline
\end{tabular}


Table 5.5. Summary statistics for categorical variables continued.

\begin{tabular}{|c|c|c|}
\hline Variable & $N$ & Percentage \\
\hline \multicolumn{3}{|l|}{$\overline{\text { Noble titles cont. }}$} \\
\hline$\overline{7=\text { Count } / \text { Countess }}$ & 295 & 11.8 \\
\hline Males & 134 & 10.0 \\
\hline Females & 161 & 13.8 \\
\hline $8=$ Lord & 192 & 7.7 \\
\hline Males & 103 & 7.7 \\
\hline Females & 89 & 7.6 \\
\hline $9=$ Emperor $/$ Empress & 20 & 0.8 \\
\hline Males & 10 & 0.7 \\
\hline Females & 10 & 0.9 \\
\hline $10=$ Margrave $/$ Margravine & 52 & 2.1 \\
\hline Males & 30 & 2.2 \\
\hline Females & 22 & 1.9 \\
\hline $11=$ Landgrave/Landgravine & 11 & 0.4 \\
\hline Males & 6 & 0.4 \\
\hline Females & 5 & 0.4 \\
\hline $12=$ Legal title & 13 & 0.5 \\
\hline Males & 12 & 0.9 \\
\hline Females & 1 & 0.1 \\
\hline $13=$ Viscount $/$ Viscountess & 16 & 0.6 \\
\hline Males & 8 & 0.6 \\
\hline Females & 8 & 0.7 \\
\hline $14=$ Regent & 6 & 0.2 \\
\hline Males & 4 & 0.3 \\
\hline Females & 2 & 0.2 \\
\hline $15=$ Marquis & 5 & 0.2 \\
\hline Males & 4 & 0.3 \\
\hline Females & 1 & 0.1 \\
\hline $16=$ Sire & 1 & 0.0 \\
\hline Males & 1 & 0.0 \\
\hline Females & 0 & 0.0 \\
\hline $17=$ Knight & 1 & 0.0 \\
\hline Males & 1 & 0.1 \\
\hline Females & 0 & 0.0 \\
\hline $18=$ Royal household & 1 & 0.0 \\
\hline Males & 1 & 0.1 \\
\hline Females & 0 & 0.0 \\
\hline $19=$ Grand Prince & 19 & 0.6 \\
\hline Males & 19 & 0.6 \\
\hline Females & 0 & 0.0 \\
\hline $20=$ Jarl & 1 & 0.0 \\
\hline Males & 1 & 0.0 \\
\hline Females & 0 & 0.0 \\
\hline
\end{tabular}


Table 5.5. Summary statistics for categorical variables continued.

\begin{tabular}{|c|c|c|}
\hline Variable & $N$ & Percentage \\
\hline \multicolumn{3}{|l|}{ Noble Titles cont. } \\
\hline $21=$ Burgrave/Burgravine & 1 & 0.0 \\
\hline Males & 1 & 0.0 \\
\hline Females & 0 & 0.0 \\
\hline $22=$ Count Palatine & 3 & 0.1 \\
\hline Males & 2 & 0.1 \\
\hline Females & 1 & 0.1 \\
\hline $23=$ Governor & 1 & 0.0 \\
\hline Males & 1 & 0.0 \\
\hline Females & 0 & 0.0 \\
\hline $24=$ Elector Palatine & 1 & 0.0 \\
\hline Males & 1 & 0.0 \\
\hline Females & 0 & 0.0 \\
\hline \multicolumn{3}{|l|}{ Enter church } \\
\hline$\overline{0=\text { no }}$ & 2298 & 91.6 \\
\hline Males & 1234 & 92.2 \\
\hline Females & 1068 & 91.4 \\
\hline $1=$ yes & 205 & 8.2 \\
\hline Males & 104 & 7.8 \\
\hline Females & 101 & 8.6 \\
\hline \multicolumn{3}{|l|}{ Attain high rank in Church } \\
\hline$\overline{0=\text { no }}$ & 2391 & 95.3 \\
\hline Males & 1264 & 94.5 \\
\hline Females & 1126 & 96.3 \\
\hline $1=$ yes & 117 & 4.7 \\
\hline Males & 74 & 5.5 \\
\hline Females & 43 & 3.7 \\
\hline \multicolumn{3}{|l|}{ Church titles } \\
\hline $0=$ None & 2293 & 91.4 \\
\hline $1=$ Abbot & 6 & 0.2 \\
\hline $2=$ Abbess $/$ Prioress & 41 & 1.6 \\
\hline $3=$ Monk & 16 & 0.6 \\
\hline $4=$ Nun & 61 & 2.4 \\
\hline $5=$ Bishop & 34 & 1.4 \\
\hline $6=$ Archbishop & 10 & 0.4 \\
\hline $7=$ Pope & 0 & 0.0 \\
\hline $8=$ Priest & 11 & 0.4 \\
\hline $9=$ Saint & 2 & 0.1 \\
\hline $10=$ Rector & 1 & 0.0 \\
\hline $11=$ Dean $/$ Provost & 6 & 0.2 \\
\hline $12=$ Prior & 1 & 0.0 \\
\hline $13=$ Archdeacon & 2 & 0.1 \\
\hline $14=$ Novice & 1 & 0.0 \\
\hline $15=$ Canon & 14 & 0.6 \\
\hline
\end{tabular}


Table 5.5. Summary statistics for categorical variables continued.

\begin{tabular}{|c|c|c|}
\hline Variable & $N$ & Percentage \\
\hline \multicolumn{3}{|l|}{$\overline{\text { Church titles cont. }}$} \\
\hline $16=$ Patriarch & 0 & 0.0 \\
\hline $17=$ Friar & 1 & 0.0 \\
\hline $18=$ Teutonic Order & 2 & 0.1 \\
\hline $19=$ Knights Templar & 3 & 0.1 \\
\hline \multicolumn{3}{|l|}{ Estate size } \\
\hline Unknown (0) & 905 & 36.1 \\
\hline Small (1) & 1461 & 58.2 \\
\hline Large (2) & 125 & 5.0 \\
\hline Grandiose (3) & 17 & 0.7 \\
\hline \multicolumn{3}{|l|}{ Relatedness } \\
\hline None & 2351 & 93.7 \\
\hline Affinal & 41 & 1.6 \\
\hline Consanguineal & 116 & 4.6 \\
\hline \multicolumn{3}{|l|}{ Spouse age $5+$ years older } \\
\hline $0=$ no & 239 & 9.5 \\
\hline Males & 129 & 9.6 \\
\hline Females & 110 & 9.4 \\
\hline $1=$ yes & 423 & 16.9 \\
\hline Males & 197 & 14.7 \\
\hline Females & 226 & 19.3 \\
\hline \multicolumn{3}{|l|}{ Families } \\
\hline Family 1 (L'Aigle) & 158 & 6.3 \\
\hline Family 2 (Bigod) & 59 & 2.4 \\
\hline Family 3 (Brus) & 31 & 1.2 \\
\hline Family 4 (Godwin) & 731 & 29.1 \\
\hline Family 5 (Marshal) & 55 & 2.2 \\
\hline Family 6 (Welf) & 118 & 4.7 \\
\hline Family 7 (Montgomery) & 355 & 14.1 \\
\hline Family 8 (Beaumont) & 152 & 6.1 \\
\hline Family 9 (de Vere) & 34 & 1.4 \\
\hline Family 10 (Avesnes) & 84 & 3.3 \\
\hline Family 11 (Northumbria) & 299 & 11.9 \\
\hline Family 12 (Flanders) & 174 & 6.9 \\
\hline Family 13 (Reginar) & 65 & 2.6 \\
\hline Family 14 (Giffard) & 143 & 5.7 \\
\hline Family 15 (de Clare) & 51 & 2.0 \\
\hline
\end{tabular}


Table 5.6. Summary statistics for continuous variables.

\begin{tabular}{lrcccc}
\hline Variable & $N$ & Min. & Max. & Mean & SD \\
\hline Children born & 4,665 & 0 & 25 & 1.86 & 2.967 \\
Sons & 2,407 & 0 & 12 & 0.96 & 1.641 \\
Daughters & 2,192 & 0 & 11 & 0.87 & 1.575 \\
Grandchildren born & 7,883 & 0 & 50 & 3.14 & 6.212 \\
Grandsons & 4,070 & 0 & 25 & 1.62 & 3.242 \\
Granddaughters & 3,707 & 0 & 25 & 1.48 & 3.173 \\
Great grandchildren born & 13,158 & 0 & 143 & 5.24 & 12.030 \\
Great-grandsons & 6,768 & 0 & 77 & 2.70 & 6.329 \\
Great-granddaughters & 6,239 & 0 & 66 & 2.49 & 5.807 \\
Great-great grandchildren born & 21,634 & 0 & 173 & 8.62 & 20.757 \\
Great-great-grandsons & 11,201 & 0 & 93 & 4.46 & 10.818 \\
Great-great-granddaughters & 10,433 & 0 & 80 & 4.10 & 10.030 \\
Number of Titles & 2,507 & 0 & 7 & 0.76 & 0.933 \\
Sons & 1336 & 0 & 6 & 0.85 & 1.040 \\
Daughters & 1169 & 0 & 7 & 0.66 & 0.780 \\
\hline
\end{tabular}

\section{Genealogy Charts}

The collected demographic data were then used to create genealogical charts for each family. The genealogy charts were created using GenoPro, a professional genealogical program. Given the size of the families and the consistent intermarriage both within and between the families, the completed genealogical charts were complex. Unlike the database where individuals were eliminated if they appeared more than once, all individuals were included in the genealogy charts. In several cases, individuals appeared within their family on multiple occasions. There were even a few instances where a child would appear in the same generation as one of their parents. Table 5.7 indicates the total number of families, individuals, and generations that were included in the genealogy charts for each of the fifteen families. 
Table 5.7. Genealogical Chart Data

\begin{tabular}{lccccc}
\hline Family & Family Code & Origins & Total Individuals & Total Families & Total Generations \\
\hline L'Aigle & 1 & French & 845 & 241 & 10 \\
Bigod & 2 & French & 28 & 13 & 5 \\
Brus & 3 & English & 74 & 32 & 8 \\
Godwin & 4 & French & 2422 & 720 & 12 \\
Marshal & 5 & English & 309 & 108 & 5 \\
Montgomerie & 6 & French & 1271 & 318 & 12 \\
Beaumont & 7 & French & 353 & 353 & 11 \\
de Vere & 8 & French & 83 & 18 & 11 \\
Avesnes & 9 & French & 212 & 43 & 7 \\
Northumbria & 10 & English & 928 & 220 & 7 \\
Flanders & 11 & French & 601 & 124 & 11 \\
Welf & 12 & French & 1845 & 562 & 7 \\
Reginar & 13 & French & 428 & 104 & 7 \\
Giffard & 14 & French & 352 & 81 & 11 \\
de Clare & 15 & English & 764 & 249 & 8 \\
\hline
\end{tabular}

In each genealogy chart, the progenitor and his wife were included as well as multiple generations spanning the 300 year time frame of the study. Known birth and death dates were included for each individual as were marriage dates. It was also noted in the charts if the marriage ended through divorce or annulment. For individuals who appeared within their family chart more than once; were color coded to make their identification easier. Not all consanguine or affinal ties were noted within the charts, but those individuals that were closely related were clearly identified. 


\section{Chapter Six: Child Survival}

\section{Introduction}

Historically infant and child mortality rates were high. In medieval Europe, mortality among children under age 5 was estimated to be between 30 and 50 percent with 20 to 30 percent of infants not surviving to their first birthday and only 50 percent of children reaching their fifth birthday (Shahar 1990). Mortality was not a respecter of social status; children of the aristocracy were just as likely to die young as their poorer counterparts. For example, Edward I, King of England, and his first wife Isabella produced 16 children (5 sons and 11 daughters) over the course of their thirty-six year marriage. Four of their five sons died before their $15^{\text {th }}$ birthday, with the youngest son and youngest child, Edward, surviving to inherit the throne. Six of their 11 daughters died before they reached their third birthday. The remaining five survived to adulthood. The mean life expectancy for all of the children was 18 with a median age of 9. Overall, only six (1 son and 5 daughters) of their 16 children survived to adulthood. The mean life expectancy of the surviving children was 42 with a median age of 39 .

Child survival can be affected by multiple factors. Climate, geographic location, and diet are all factors that can impact child survival (Orme, 2003). In infants specifically, weaning was especially dangerous. In addition, the birth order of the child, its gender, parental investment, availability of resources, and maternal health can have both positive and negative effects on survival. Children may receive additional investment from their parents depending on their birth order and gender with some birth orders and genders receiving preferential treatment over others. For example, in societies with heritable wealth, there may be a preference for a specific gender such as 
primogeniture (eldest child inherits, most often eldest son), ultimogeniture (youngest child inherits), or secundogeniture (inheritance by the second born, typically sons). While not universal, the inheritance pattern of primogeniture is the most common in societies with large amounts of heritable wealth. As a result of primogeniture, older children will receive preferential treatment over younger children and sons will receive preferential treatment over daughters. Children with earlier birth orders were vital in securing the position of the family in medieval society, thus younger children could be expected to have higher infant and child mortality rates than their older siblings.

There are several possible reasons we would expect this pattern. First, parents will invest additional resources in their oldest children because they are either the heir to the familial estate (sons) or the first means by which to secure a political/marriage alliance (daughters). Second, children who have a higher birth order will have the benefit of additional parental investment simply as the result of time - their parents will be younger and more likely to survive throughout their childhood and into their adulthood. For example, maternal mortality would be expected to impact child survival through a decrease or lack of maternal investment. If the mother dies early in the child's lifetime, the amount of potential parental investment has been decreased by half. As many as 20 percent of women in medieval Europe died either in childbirth or as a direct result of childbirth complications. Depending on the age of the child at the death of the mother, the mortality rate of the child may be even higher. Finally, the more children born to a couple, the less time/resources will be available to distribute to additional children.

The remainder of the chapter tests several hypotheses related to child survival in the study population. 
Hypothesis 1a) First and second born sons will be more likely to survive to age 5 than their younger brothers.

Hypothesis 2a) First and second born daughters are more likely to survive to age 5 than their younger sisters.

Hypotheses 1a and 2a were examined using binary logistic regression with the outcome variable survival to age $5(0=$ did not survive, $1=$ survived $)$; see Table 6.1 for results. The data were divided by sex $(0=$ female, $1=$ male $)$. Predictor variables used in the model included dummy variables for first born and second born, whether or not the children died before their mother $(0=\mathrm{No}, 1=\mathrm{Yes})$, country code ( $1=$ England, $2=$ France), and a categorical variable representing historic time period. The time periods were identified as follows: Period (1): 1000-1066, Period (2): 1066-1154, (3):1155-1215, (4): 1216-1300. In Time Period 1 both England and France were relatively unstable with intermittent periods of consistent rule. Time Period 2 was characterized by the Norman invasion which shifted the political landscape in England. In France the Capetian kings maintained their rule. Time Period 3 saw an unstable England while French stability continued under the Capetians. In Time Period 4 England and France were both stable as the two countries saw some of the most powerful rulers of the medieval period.

The results from this analysis (see Table 6.1) indicated that there was a positive effect on survival of being a first or second born son. First born sons had an odds ratio of 2.201 suggesting they are 2.2 times more likely to survive to age 5 than their younger brothers $(\mathrm{p}=0.001)$. Second born sons had an odds ratio of $1.659(\mathrm{p}=0.059)$. There was also a positive effect of being a first or second born daughter on survival to age 5, though only the result for first born daughters was significant. First born daughters had an odds 
ratio of 2.355 suggesting they are 2.4 times more likely to survive to age 5 than their younger siblings $(\mathrm{p}=0.021)$. As expected, there was a stronger effect for first and second born sons when compared to first and second born daughters.

Table 6.1. Results of a Binary Logistic Regression using independent variables first and second born sons and daughters and dependent variable child survival to age 5 .

\begin{tabular}{lcccr}
\hline Variable & Estimate & SE & $p$ & Odds Ratio \\
\hline First born sons & 0.789 & 0.242 & 0.001 & 2.201 \\
Second born sons & 0.506 & 0.267 & 0.059 & 1.659 \\
Died before mother (N) & 1.540 & 0.326 & 0.000 & 4.665 \\
Died before mother (Y) & -1.718 & 0.246 & 0.000 & 0.179 \\
Country code & -0.549 & 0.263 & 0.037 & 0.577 \\
Historic time period 1 & 1.582 & 1.044 & 0.130 & 4.867 \\
Historic time period 2 & -0.358 & 0.331 & 0.280 & 0.699 \\
Historic time period 3 & -0.438 & 0.237 & 0.064 & 0.645 \\
& & & & \\
First born daughters & 0.857 & 0.370 & 0.021 & 2.355 \\
Second born daughters & 0.484 & 0.361 & 0.180 & 1.622 \\
Died before mother (N) & 1.883 & 0.464 & 0.000 & 6.572 \\
Died before mother (Y) & -1.999 & 0.273 & 0.000 & 0.136 \\
Country code & -0.626 & 0.315 & 0.047 & 0.535 \\
Historic time period 1 & 18.72 & 9630.241 & 0.998 & 135265092.966 \\
Historic time period 2 & 0.149 & 0.420 & 0.722 & 1.161 \\
Historic time period 3 & 0.369 & 0.324 & 0.255 & 1.446 \\
& & & & \\
\hline
\end{tabular}

\section{Hypothesis 1b) First and second born sons will be more likely to survive to age 15 than}

their younger brothers.

\section{Hypothesis 2b) First and second born daughters are more likely to survive to age 15}

than their younger sisters.

In order to test hypotheses $1 \mathrm{~b}$ and $2 \mathrm{~b}$, a binary logistic regression was used. See Table 6.2 for results. Survival to age 15 was the dependent variable and first and second born, died before mother $(0=$ No, $1=$ Yes $)$, country code ( $1=$ England, $2=$ France $)$, and historic time period (Period 1: 1000-1066, Period 2: 1066-1154, Period 3: 1155-1215. Period 4: $1216-1300)$ were the predictors. The data were also divided by sex ( $0=$ female, 
$1=$ male). There was a significant result for both first and second born males $(\mathrm{p}=0.000$

and 0.000 respectively) with first born sons showing an odds ratio of 2.805 suggesting

they are 2.8 times more likely to survive to age 15 than their younger brothers while

second born sons had an odds ratio of 2.328. First born and second born daughters

showed no significant results.

Table 6.2. Results of a Binary Logistic Regression using variables independent variables first and second born sons and daughters and dependent variable child survive to age 15 .

\begin{tabular}{lcccc}
\hline Variable & Estimate & SE & $p$ & Odds Ratio \\
\hline First born sons & 1.031 & 0.216 & 0.000 & 2.805 \\
Second born sons & 0.845 & 0.243 & 0.000 & 2.328 \\
$\quad$ Died before mother (N) & 2.105 & 0.293 & 0.000 & 8.204 \\
Died before mother (Y) & -1.737 & 0.209 & 0.000 & 0.176 \\
Country code & -0.058 & 0.253 & 0.818 & 0.943 \\
Historic time period 1 & 1.088 & 0.648 & 0.093 & 2.969 \\
Historic time period 2 & -0.446 & 0.274 & 0.104 & 0.640 \\
Historic time period 3 & -0.520 & 0.217 & 0.017 & 0.594 \\
& & & & \\
First born daughters & 0.200 & 0.283 & 0.480 & 1.222 \\
Second born daughters & 0.281 & 0.304 & 0.355 & 1.325 \\
Died before mother (N) & 1.540 & 0.342 & 0.000 & 4.664 \\
Died before mother (Y) & -2.069 & 0.237 & 0.000 & 0.126 \\
Country code & -0.287 & 0.283 & 0.310 & 0.751 \\
Historic time period 1 & 19.128 & 8867.467 & 0.998 & 202825878.618 \\
Historic time period 2 & 0.204 & 0.376 & 0.588 & 1.226 \\
Historic time period 3 & -0.234 & 0.255 & 0.360 & 0.792 \\
\hline
\end{tabular}

Hypothesis 3a) First and second born sons will be more likely to survive to age 5 than their sisters regardless of birth order.

Hypothesis 3b) First and second born daughters will be more likely to survive to age 5 and 15 than younger born sons (birth order 3 and higher).

Using descriptive statistics, (see Table 6.3) females appear to be more successful in terms of survival than males. Ninety-five percent of first and second born daughters survived to age $5(n=406)$ while only 91 percent of first and second born males $(n=660)$ 
survived to the same age. Daughters with a birth order of three or higher $(n=698)$ had a survival rate of 91 percent while sons with a birth order of three or higher $(n=575)$ had a survival rate of 87 percent. Hypothesis 3 a was thus rejected. First and second born sons were not more likely to survive than their sisters regardless of birth order. Hypothesis $3 \mathrm{~b}$ was supported, as first and second born daughters were more likely to survive to age 5 than all other children, including not only later born sons but also first and second born sons.

Table 6.3. Descriptive statistics showing results for effect of birth order and gender on likelihood of surviving to age $5(0=$ did not survive, $1=$ survived).

\begin{tabular}{lccc}
\hline Variable & $N$ & Mean & SD \\
\hline Males & & & \\
First and second born & 660 & 0.91 & 0.288 \\
Third born and up & 575 & 0.87 & 0.341 \\
& & & \\
Females & 406 & 0.95 & 0.227 \\
First and second born & 698 & 0.91 & 0.285 \\
Third born and up & & &
\end{tabular}

A more rigorous test for effects of sex and birth order (see Table 6.4 below) shows that for each birth order - first born, second born, and $3^{\text {rd }}$ born and higher - there is an interaction between sex and birth order with males significantly less likely (at the $\mathrm{p}=0.1$ level) to survive than their sisters at the same birth order. We can thus conclude that not only were girls more likely to survive than boys overall, but that this relationship persists across birth orders. 
Table: 6.4. Results of binary logistic regression estimates using independent variables sex and birth order and dependent variable survive to age 5 .

\begin{tabular}{lccc}
\hline Variable & Estimate & SE & $p$ \\
\hline Sex M/F & 3.879 & 1.7715 & 0.029 \\
First born & 2.236 & 1.4119 & 0.113 \\
Second born & 2.536 & 1.4121 & 0.072 \\
Birth order 3 and up & 2.888 & 1.4051 & 0.040 \\
Interactions: & & & \\
$\quad$ Sex M/F by 1 & & \\
Sex M/F by 2 $2^{\text {nd }}$ born & -3.235 & 1.7805 & 0.069 \\
Sex M/F by 3d born and up & -3.444 & 1.7836 & 0.053 \\
\hline
\end{tabular}

Similar results were found using survival to age 15 as the dependent variable (see Table 6.5). Ninety percent of first and second born daughters $(n=419)$ survived to age 15 . In comparison, 88 percent of first and second born sons $(n=672)$ survived to age 15 . Among daughters with a birth order of three or higher, 89 percent $(n=708)$ survived to age 15. Sons in the same category $(n=599)$ had a survival rate of 80 percent. Once again, Hypothesis 3a was not supported but Hypothesis $3 \mathrm{~b}$ was supported. First and second born sons were less likely to survive to age 15 than first and second born daughters, but first and second born daughters were more likely to survive to age 15 than younger born sons (and in fact all other children).

Table 6.5. Descriptive statistics showing results for effect of birth order and gender on likelihood of surviving to age 15 ( $0=$ did not survive, $1=$ survived).

\begin{tabular}{lccc}
\hline Variable & $N$ & Mean & SD \\
\hline Males & & & \\
\hline First and second born & 672 & 0.88 & 0.331 \\
Third born and up & 599 & 0.80 & 0.402 \\
& & & \\
Females & 419 & 0.90 & 0.301 \\
First and second born & 708 & 0.89 & 0.317 \\
Third born and up & &
\end{tabular}


Regression estimates in Table 6.6 likewise show that the interactions between sex and birth order persist for survival to age 15 , with sons at all birth orders less likely to survive than daughters at the same birth order - though these effects are weaker than for survival to age 5 , and only significant (at the $\mathrm{p}=0.1$ level) for first and second born daughters.

Table: 6.6. Results of bivariate logistic regression estimates using independent variables sex and birth order and dependent variable survival to age 15 .

\begin{tabular}{lccc}
\hline Variable & Estimate & SE & $p$ \\
\hline Sex M/F & 3.065 & 1.6949 & 0.071 \\
First born & 2.201 & 1.3644 & 0.107 \\
Second born & 2.145 & 1.3647 & 0.0116 \\
Birth order 3 and up & 2.289 & 1.3586 & 0.092 \\
Interactions: & & & \\
$\quad$ Sex M/F by 1 & & \\
Sex M/F by 2 born $^{\text {nd }}$ born & -2.855 & 1.7011 & 0.093 \\
Sex M/F by 3 & -2.800 & 1.7046 & 0.100 \\
\end{tabular}




\section{Chapter Seven Results: Parental Investment}

\section{Introduction}

In chapter 6 we examined child survival to the ages of 5 and 15. Child survival is one outcome of parental investment. In this chapter we will examine child outcomes related to wealth and status as an additional measure of parental investment. As discussed in the introductory chapters, first born sons are expected to receive the highest level of investment. Second born sons will also receive high levels of parental investment. This investment will most often take the form of wealth, land, and titles. As the birth order increases, the amount of parental investment will decrease. This means that younger born sons, starting with a birth order of 3 and above, may receive titles of lesser quality or religious titles versus secular titles. Specifically, sons with a higher birth order will be more likely to join the church and less likely to inherit direct titles from their fathers. Moreover, within sons who entered the church, those who were older/had a lower birth order would be more likely to receive higher levels of investment (mostly in terms of the transfer of funds) allowing them to become Abbots or Bishops as opposed to monks or priests.

Parental investment in daughters will also vary. First born daughters will receive a higher level of investment than their younger sisters. Parents will provide larger dowries and make more advantageous marriages for their first born daughters than their daughters with higher birth orders. Second born daughters will also receive a high level of parental investment (with dowries and advantageous marriages, but not as high as the investment given to their older sisters. As the birth order of daughters' increases, the amount of parental investment is also expected to decrease. Daughters with a birth order of 3 and 
above were more likely to receive parental investment in the form of placement in the church instead of receiving a dowry or a good marriage. Within daughters who entered the church, those who were older/had a lower birth order were more likely to become an Abbess or Prioress as opposed to becoming a nun.

Hypothesis 4a: Parents will invest most heavily in their first born and second born sons as reflected in more titles and higher titles.

This hypothesis was tested using a generalized linear model. The number of titles each son held was used as the dependent variable. Covariates included dummy variables for birth order (first born sons, second born sons), died before father ( $0=$ no, $1=y e s)$, country code (1=England, 2=France), and historic time period (Period 1: 1000-1066, Period 2: 1066-1154, Period 3: 1155-1215, Period 4: 1216-1300). The total number of titles held by eldest sons and second born sons was compared to the number of titles held by younger sons. As seen in Table 7.1, first and second born sons are statistically more likely to hold more titles (positive effect of $0.171, p=0.005$ and $0.165, p=0.013$ respectively) than their younger brothers. There was also a positive correlation for first and second born sons to hold more titles than their younger brothers in time periods 2 and 3 as compared to time period 4 . As might be expected, first and second born sons were also likely to hold more titles if they did not die before their fathers. 
Table: 7.1. Generalized linear model showing the results for independent variables sex and birth order and outcome variable number of titles.

\begin{tabular}{lccc}
\hline Variable & Estimate & SE & $p$ \\
\hline First born sons & 0.171 & 0.0610 & 0.005 \\
Second born sons & 0.165 & 0.0665 & 0.013 \\
Died before father (N) & 0.835 & 0.0654 & 0.000 \\
Died before father (Y) & 0.000 & 0.0863 & 0.998 \\
Country Code & -0.183 & 0.0682 & 0.007 \\
Historic time period 1 & 0.011 & 0.1461 & 0.938 \\
Historic time period 2 & 0.231 & 0.0803 & 0.004 \\
Historic time period 3 & 0.114 & 0.0635 & 0.072 \\
& & & 0.002 \\
Sons Birth order 3 and up & -0.163 & 0.0523 & 0.000 \\
Died before father (N) & 0.612 & 0.0463 & 0.810 \\
Died before father (Y) & 0.017 & 0.0699 & 0.007 \\
Country Code & -0.185 & 0.0682 & 0.928 \\
Historic time period 1 & 0.013 & 0.1462 & 0.004 \\
Historic time period 2 & 0.233 & 0.0802 & 0.068 \\
Historic time period 3 & 0.116 & 0.0635 & \\
\hline
\end{tabular}

As seen in Table 7.1 there was a negative correlation for third born sons and the number of titles held. The negative effect $(-0.163)$ with a $\mathrm{p}$ value of 0.002 indicates that third born sons were less likely to hold a title than their older brothers who had a birth order of one or two.

In two separate analyses, the rank of titles held were examined for first and second born sons and daughters as well as those sons and daughters with a birth order of 3 and higher. The first analysis was completed using a multinomial logistic regression model. The dependent variable was coded using the highest title held. For males this included:1=king, 2=prince, $3=$ duke, 4=baron, 5=earl, 6=grand duke, 7=count, 8=lord, $9=$ emperor, $10=$ margrave, $11=$ landgrave, 12=law, 13=viscount, 14=regent, 15=marquis, 16=sire, 17=knight, 18=royal household, 19=grand prince, $20=$ jarl, $21=$ burgrave, $22=$ count palatine, $23=$ patriarch, $24=$ governor, $25=$ elector palatine. Titles were also coded for females: 1=queen/queen consort, $2=$ prince, $3=$ duchess, $4=$ baroness, 
5=countess, $6=$ grand duchess, $7=$ countess, $8=1$ lady, $9=$ empress/empress consort, $10=$ margravine, $11=$ landgravine, $13=$ viscountess, $15=$ marquess. There was not a female code for $12=$ law, $14=$ regent, or title numbers $12-25$. For analysis, the titles were divided into four categories based on rank (Category 4: king/queen, emperor/empress, prince/princess, grand prince, regent; Category 3: duke/duchess, grand duke/grand duchess, and count palatine; Category 2: margrave/margravine, landgrave/landgravine, viscount/viscountess, burgrave/burgravine, elector palatine; Category 1: baron/baroness, earl/countess, count/countess, lord, law, marquis/marquess, and jarl). Dummy variables were created for the predictors first and second born sons, and the covariates died before father $(0=$ No, $1=$ Yes $)$, country code $(1=$ England, $2=$ France $)$, and historic time period (Period 1: 1000-1066, Period 2: 1066-1154, Period 3: 1155-1215, Period 4: 1216-1300).

Table 7.2 shows odds ratios of 1.957 and 2.032 for first and second born sons $(\mathrm{p}=0.006$ and 0.005$)$ in category 1 . This indicates that both first and second born sons were nearly 2 times as likely to hold a high ranking title (king, emperor, prince, grand prince, regent) as their younger brothers with a birth order of 3 and up. Sons with a birth order of 3 and up were less likely to hold a high title (odds ratio $0.496, p=0.001$ ) than their older brothers.

In title category 3 (duke, grand duke, count palatine) first born sons had an odds ratio of $1.527(\mathrm{p}=0.062)$. This indicates that first born sons were 1.5 times more likely to hold a title of duke, grand duke, or count palatine as their younger brothers. Second born sons and sons with a birth order of 3 and above were less likely to hold a title in category 3 (odds ratio 0.901 and 0.802 ). Sons with a birth order of 2 and 3 and above were 0.9 and 0.8 times less likely to hold a title in category 3 . 
In title category 2 (margrave, landgrave, viscount, burgrave, elector palatine) first and second born sons show an odds ratio of 2.515 and 2.454 ( $\mathrm{p}=0.008$ and 0.013 ). This indicates that first and second born sons are 2.5 and 2.4 times as likely to hold titles in category 2 as their younger brothers. As in category 4 and category 3 , sons with a birth order of 3 and above were less likely to hold a title in category 2 (odds ratio 0.416, $\mathrm{p}=0.003$ ). This indicates that sons with a birth order of 3 and above were 0.4 times less likely to hold a title as their older brothers.

In category 1 (baron, earl, count, lord, law, marquis, and jarl) first and second born sons had an odds ratio of 2.723 and $2.159(\mathrm{p}=0.000)$. This indicates that first and second born sons were 2.7 and 2.1 times as likely to hold a title in category 1 as their younger brothers. Similarly, sons with a birth order of 3 and above were less likely to hold a title in this category (odds ratio of $0.410, \mathrm{p}=0.000$ ).

Table 7.2 also shows the titles held by females in the sample population. In some cases the titles were inherited or bestowed as part of a woman's dowry. The majority of the titles, however, were acquired through marriage. First born females had an odds ratio of $1.856(\mathrm{p}=0.025)$ for category 4 titles (queen/queen consort, empress/empress consort, or princess). This indicates that first born daughters were 1.8 times more likely to hold a title in category 4 than their younger sisters. There was no significance for second born daughters. Daughters with a birth order of 3 and up were significantly less likely (negative effect and an odds ratio of $0.587, \mathrm{p}=0.021$ ) to hold a high ranking title than their older sisters.

In category 3 (duchess and grand duchess) first and second born daughters were more likely to hold titles than their younger sisters (odds ratio 2.205 and 2.142, $\mathrm{p}=0.006$ 
and 0.014). First and second born daughters were therefore 2.2 and 2.1 times as likely to hold a title in category 3. Daughters with a birth order of 3 and above had a negative effect (odds ratio $0.587, \mathrm{p}=0.001$ ). This indicates that daughters with a higher birth order were 0.5 times less likely to hold a title than their older sisters.

In category 2 (margravine, landgravine, and burgravine) there was no significance for daughters of any birth order. In category 1 (baroness, countess, lady, marquess), first and second born daughters had an odds ratio of 1.889 and $1.858(\mathrm{p}=0.001$ and 0.002$)$. First and second born daughters were therefore 1.8 times more likely to hold titles in category 1 than their younger sisters. As was consistent with females with a birth order of 3 and up in the other categories, were less likely to hold a title than their older sisters (effect -1.658 and odds ratio of $0.518 \mathrm{p}=0.000$ ). 
Table 7.2 Multinomial logistic regression showing the results for effect of birth order and highest title for sons and daughters.

\begin{tabular}{|c|c|c|c|c|}
\hline Variable & Estimate & SE & $p$ & Odds Ratio \\
\hline \multicolumn{5}{|l|}{$\underline{\text { Sons }}$} \\
\hline \multicolumn{5}{|l|}{ Title Category 4} \\
\hline First born sons & 0.671 & 0.243 & 0.006 & 1.957 \\
\hline Second born sons & 0.709 & 0.255 & 0.005 & 2.032 \\
\hline Died before father $(\mathrm{N})$ & 3.431 & 0.439 & 0.000 & 18.117 \\
\hline Died before father (Y) & 0.876 & 0.622 & 0.159 & 1.828 \\
\hline County Code & -0.860 & 0.365 & 0.019 & 0.555 \\
\hline Historic time period 1 & 0.996 & 0.894 & 0.265 & 1.018 \\
\hline Historic time period 2 & 1.001 & 0.378 & 0.008 & 1.771 \\
\hline Historic time period 3 & 0.267 & 0.268 & 0.318 & 1.998 \\
\hline Sons birth order 3 and up & -0.701 & 0.208 & 0.001 & 0.496 \\
\hline Died before father $(\mathrm{N})$ & 2.891 & 0.404 & 0.000 & 18.006 \\
\hline Died before father (Y) & 0.599 & 0.509 & 0.239 & 1.821 \\
\hline Country Code & -0.598 & 0.288 & 0.038 & 0.550 \\
\hline Historic time period 1 & 0.033 & 0.678 & 0.962 & 1.033 \\
\hline Historic time period 2 & 0.567 & 0.311 & 0.068 & 1.763 \\
\hline Historic time period 3 & 0.686 & 0.234 & 0.003 & 61.985 \\
\hline \multicolumn{5}{|l|}{ Title Category 3} \\
\hline First born sons & 0.424 & 0.227 & 0.062 & 1.527 \\
\hline Second born sons & -0.105 & 0.274 & 0.703 & 0.901 \\
\hline Died before father $(\mathrm{N})$ & 4.884 & 1.009 & 0.000 & 132.165 \\
\hline Died before father (Y) & 2.803 & 1.042 & 0.007 & 16.488 \\
\hline Country Code & -0.693 & 0.277 & 0.012 & 0.500 \\
\hline Historic time period 1 & -18.829 & 6235.322 & 0.998 & $6.646 \mathrm{E}-9$ \\
\hline Historic time period 2 & 0.024 & 0.324 & 0.941 & 1.024 \\
\hline Historic time period 3 & -0.180 & 0.250 & 0.472 & 0.835 \\
\hline Sons birth order 3 and up & -0.220 & 0.198 & 0.265 & 0.802 \\
\hline Died before father $(\mathrm{N})$ & 4.904 & 1.009 & 0.000 & 134.761 \\
\hline Died before father (Y) & 2.834 & 1.042 & 0.007 & 17.014 \\
\hline Country Code & -0.692 & 0.276 & 0.012 & 0.501 \\
\hline Historic time period 1 & -18.839 & 6230.019 & 0.998 & $6.581 \mathrm{E}-9$ \\
\hline Historic time period 2 & 0.045 & 0.323 & 0.889 & 1.046 \\
\hline Historic time period 3 & -0.160 & 0.249 & 0.521 & 0.852 \\
\hline
\end{tabular}


Table 7.2 Multinomial logistic regression showing results for effect of birth order and highest title for sons and daughters continued.

\begin{tabular}{|c|c|c|c|c|}
\hline Variable & Estimate & $\mathrm{SE}$ & $p$ & Odds Ratio \\
\hline \multicolumn{5}{|l|}{ Title Category 2} \\
\hline First born sons & 0.922 & 0.346 & 0.008 & 2.515 \\
\hline Second born sons & 0.898 & 0.363 & 0.013 & 2.454 \\
\hline Died before father $(\mathrm{N})$ & 2.694 & 0.605 & 0.000 & 14.796 \\
\hline Died before father (Y) & 0.168 & 0.827 & 0.839 & 1.183 \\
\hline Country Code & 0.450 & 0.320 & 0.159 & 1.569 \\
\hline Historic time period 1 & -19.096 & 0.000 & - & $5.090 \mathrm{E}-9$ \\
\hline Historic time period 2 & -0.613 & 0.557 & 0.271 & 0.542 \\
\hline Historic time period 3 & -0.539 & 0.410 & 0.188 & 0.583 \\
\hline Sons birth order 3 and up & -0.878 & 0.299 & 0.003 & 0.416 \\
\hline Died before father $(\mathrm{N})$ & 2.692 & 0.605 & 0.000 & 14.764 \\
\hline Died before father $(\mathrm{Y})$ & 0.165 & 0.826 & 0.842 & 1.179 \\
\hline Country Code & 0.438 & 0.319 & 0.170 & 1.550 \\
\hline Historic time period 1 & -19.083 & 0.000 & - & $5.157 \mathrm{E}-9$ \\
\hline Historic time period 2 & -0.601 & 0.557 & 0.280 & 0.548 \\
\hline Historic time period 3 & -0.538 & 0.409 & 0.188 & 0.584 \\
\hline \multicolumn{5}{|l|}{ Title Category 1} \\
\hline First born sons & 1.002 & 0.170 & 0.000 & 2.723 \\
\hline Second born sons & 0.770 & 0.182 & 0.000 & 2.159 \\
\hline Died before father $(\mathrm{N})$ & 1.532 & 0.173 & 0.000 & 4.628 \\
\hline Died before father (Y) & -0.696 & 0.264 & 0.009 & 0.499 \\
\hline Country Code & -0.365 & 0.189 & 0.053 & 0.694 \\
\hline Historic time period 1 & 0.914 & 0.367 & 0.013 & 2.493 \\
\hline Historic time period 2 & 0.429 & 0.220 & 0.051 & 1.536 \\
\hline Historic time period 3 & 0.151 & 0.178 & 0.396 & 1.163 \\
\hline Sons birth order 3 and up & -0.892 & 0.146 & 0.000 & 0.410 \\
\hline Died before father $(\mathrm{N})$ & 1.543 & 0.173 & 0.000 & 4.677 \\
\hline Died before father (Y) & -0.678 & 0.264 & 0.010 & 0.507 \\
\hline Country Code & -0.370 & 0.189 & 0.050 & 0.691 \\
\hline Historic time period 1 & 0.924 & 0.368 & 0.012 & 2.518 \\
\hline Historic time period 2 & 0.444 & 0.219 & 0.043 & 1.559 \\
\hline Historic time period 3 & 0.162 & 0.177 & 0.359 & 1.176 \\
\hline
\end{tabular}


Table 7.2 Multinomial logistic regression showing results for effect of birth order and highest title for sons and daughters continued.

\begin{tabular}{|c|c|c|c|c|}
\hline Variable & Estimate & SE & $p$ & Odds Ratio \\
\hline \multicolumn{5}{|l|}{ Daughters } \\
\hline \multicolumn{5}{|l|}{ Title Category 4} \\
\hline First born daughters & 0.618 & 0.277 & 0.025 & 1.856 \\
\hline Second born daughters & 0.382 & 0.314 & 0.223 & 1.466 \\
\hline Died before father $(\mathrm{N})$ & 3.426 & 0.439 & 0.000 & 30.747 \\
\hline Died before father (Y) & 0.867 & 0.622 & 0.164 & 2.379 \\
\hline County Code & -0.855 & 0.365 & 0.019 & 0.425 \\
\hline Historic time period 1 & 0.947 & 0.897 & 0.291 & 2.578 \\
\hline Historic time period 2 & 1.000 & 0.378 & 0.008 & 2.717 \\
\hline Historic time period 3 & 0.266 & 0.268 & 0.320 & 1.305 \\
\hline Daughters birth order 3 and up & -0.533 & 0.231 & 0.021 & 0.587 \\
\hline Died before father $(\mathrm{N})$ & 3.431 & 0.439 & 0.000 & 30.909 \\
\hline Died before father (Y) & 0.876 & 0.622 & 0.159 & 2.402 \\
\hline Country Code & -0.860 & 0.365 & 0.019 & 0.423 \\
\hline Historic time period 1 & 0.996 & 0.894 & 0.265 & 2.706 \\
\hline Historic time period 2 & 1.001 & 0.378 & 0.008 & 2.722 \\
\hline Historic time period 3 & 0.267 & 0.268 & 0.318 & 1.307 \\
\hline \multicolumn{5}{|l|}{ Title Category 3} \\
\hline$\overline{\text { First born daughters }}$ & 0.791 & 0.288 & 0.006 & 2.205 \\
\hline Second born daughters & 0.762 & 0.310 & 0.014 & 2.142 \\
\hline Died before father $(\mathrm{N})$ & 3.874 & 0.600 & 0.000 & 48.113 \\
\hline Died before father (Y) & 1.964 & 0.691 & 0.004 & 7.129 \\
\hline County Code & 0.044 & 0.298 & 0.883 & 1.045 \\
\hline Historic time period 1 & -18.007 & 0.000 & - & $1.512 \mathrm{E}-8$ \\
\hline Historic time period 2 & 0.820 & 0.403 & 0.042 & 2.270 \\
\hline Historic time period 3 & 0.103 & 0.287 & 0.718 & 1.109 \\
\hline Daughters birth order 3 and up & -0.823 & 0.238 & 0.001 & 0.439 \\
\hline Died before father $(\mathrm{N})$ & 3.874 & 0.600 & 0.000 & 47.993 \\
\hline Died before father (Y) & 1.964 & 0.0691 & 0.004 & 7.129 \\
\hline Country Code & 0.044 & 0.298 & 0.883 & 1.045 \\
\hline Historic time period 1 & -18.007 & 0.000 & - & $1.512 \mathrm{E}-8$ \\
\hline Historic time period 2 & 0.819 & 0.403 & 0.042 & 2.268 \\
\hline Historic time period 3 & 0.100 & 0.287 & 0.727 & 1.105 \\
\hline
\end{tabular}


Table 7.2 Multinomial logistic regression showing results for effect of birth order and highest title for sons and daughters continued.

\begin{tabular}{|c|c|c|c|c|}
\hline Variable & Estimate & $\mathrm{SE}$ & $p$ & Odds Ratio \\
\hline \multicolumn{5}{|l|}{ Title Category 2} \\
\hline First born daughters & 0.320 & 0.413 & 0.439 & 1.377 \\
\hline Second born daughters & 0.707 & 0.400 & 0.077 & 2.028 \\
\hline Died before father $(\mathrm{N})$ & 2.190 & 0.465 & 0.000 & 8.933 \\
\hline Died before father $(\mathrm{Y})$ & 1.137 & 0.581 & 0.050 & 3.116 \\
\hline County Code & -0.020 & 0.415 & 0.961 & 0.980 \\
\hline Historic time period 1 & 1.691 & 0.868 & 0.052 & 5.423 \\
\hline Historic time period 2 & -1.053 & 1.035 & 0.309 & 0.349 \\
\hline Historic time period 3 & -0.035 & 0.384 & 0.927 & 0.966 \\
\hline Daughters birth order 3 and up & -0.603 & 0.318 & 0.058 & 0.547 \\
\hline Died before father $(\mathrm{N})$ & 2.175 & 0.464 & 0.000 & 8.800 \\
\hline Died before father $(\mathrm{Y})$ & 1.098 & 0.579 & 0.058 & 2.999 \\
\hline Country Code & -0.040 & 0.415 & 0.924 & 0.961 \\
\hline Historic time period 1 & 1.601 & 0.866 & 0.064 & 4.956 \\
\hline Historic time period 2 & -1.054 & 1.035 & 0.309 & 0.349 \\
\hline Historic time period 3 & -0.040 & 0.384 & 0.917 & 0.961 \\
\hline \multicolumn{5}{|l|}{ Title Category 1} \\
\hline First born daughters & 0.636 & 0.188 & 0.001 & 1.889 \\
\hline Second born daughters & 0.620 & 0.201 & 0.002 & 1.858 \\
\hline Died before father $(\mathrm{N})$ & 1.310 & 0.159 & 0.000 & 3.707 \\
\hline Died before father (Y) & -0.709 & 0.280 & 0.011 & 0.492 \\
\hline County Code & 0.033 & 0.188 & 0.860 & 1.034 \\
\hline Historic time period 1 & 0.609 & 0.551 & 0.269 & 1.839 \\
\hline Historic time period 2 & 0.420 & 0.252 & 0.095 & 1.522 \\
\hline Historic time period 3 & 0.038 & 0.178 & 0.832 & 1.039 \\
\hline Daughters birth order 3 and up & -0.658 & 0.152 & 0.000 & 0.518 \\
\hline Died before father $(\mathrm{N})$ & 1.309 & 0.159 & 0.000 & 3.704 \\
\hline Died before father (Y) & -0.710 & 0.280 & 0.011 & 0.491 \\
\hline Country Code & 0.023 & 0.188 & 0.902 & 1.023 \\
\hline Historic time period 1 & 0.608 & 0.551 & 0.269 & 1.838 \\
\hline Historic time period 2 & 0.422 & 0.252 & 0.095 & 1.524 \\
\hline Historic time period 3 & 0.039 & 0.178 & 0.827 & 1.040 \\
\hline
\end{tabular}




\section{Hypothesis 4b) First and second born sons will be less likely to join the church than}

their younger brothers. Sons with a birth order of three or higher will be more likely to enter the church than their older brothers.

Hypothesis $4 \mathrm{~b}$ was tested using a binary logistic regression model within the generalized linear model framework. Dummy variables were created for the dependent variable of joining the church $(0=\mathrm{No}, 1=\mathrm{Yes})$, the predictors first born, second born, and birth order 3 and up ( $0=\mathrm{No}, 1=$ Yes $)$, and the covariates died before the father $(0=\mathrm{No}$, 1=Yes), country code (1=England, 2=France), and historic time period (Period 1: 10001066, Period 2: 1066-1154, Period 3: 1155-1215, Period 4: 1216-1300).

Table 7.3 revealed an odds ratio of 0.168 for first born sons $(\mathrm{p}=0.000)$ indicating that first born sons were nearly 0.16 times less likely to join the church as their younger brothers. Second born sons had an odds ratio of $0.443(\mathrm{p}=0.003)$. Second born sons were then 0.44 times less likely to join the church as their younger brothers. Neither the variables dying before father nor the country had any significant effect on the outcome variable. Time periods 1 and 2 showed no significant effects, but time period 3 showed a negative effect (odds ratio of 0.325$)$ and a significant $\mathrm{p}$ value $(\mathrm{p}=0.001)$ suggesting that children living in time period three were less likely to enter the church compared to children in time period 4. 
Table: 7.3. Binary logistic regression model showing the results for independent variables sons and birth order and the dependent variable enter Church.

\begin{tabular}{llccc}
\hline Variable & Estimate & $\mathrm{SE}$ & $p$ & Odds Ratio \\
\hline First born sons & -1.783 & 0.361 & 0.000 & 0.168 \\
Second born sons & -0.814 & 0.275 & 0.003 & 0.443 \\
$\quad$ Died before father (N) & -0.224 & 0.241 & 0.354 & 0.799 \\
Died before father (Y) & -1.445 & 0.466 & 0.002 & 0.236 \\
Country Code & -0.046 & 0.277 & 0.869 & 0.955 \\
Historic time period 1 & -0.881 & 0.746 & 0.237 & 0.414 \\
Historic time period 2 & 0.31 & 0.302 & 0.919 & 1.031 \\
Historic time period 3 & -1.124 & 0.348 & 0.001 & 0.325 \\
& & & & \\
Sons birth order 3 and up & 1.217 & 0.231 & 0.000 & 3.376 \\
Died before father (N) & -0.247 & 0.241 & 0.305 & 0.781 \\
Died before father (Y) & -1.474 & 0.465 & 0.002 & 0.229 \\
Country Code & -0.041 & 0.276 & 0.883 & 0.960 \\
Historic time period 1 & -.890 & 0.745 & 0.232 & 0.410 \\
Historic time period 2 & -0.005 & 0.300 & 0.986 & 0.995 \\
Historic time period 3 & -1.149 & 0.348 & 0.001 & 0.317 \\
\hline
\end{tabular}

Table 7.3 shows an odds ratio of 3.043 for sons with a birth order of three and higher $(\mathrm{p}=0.000)$. This indicates that sons with higher birth orders are 3 times more likely to enter the church than their older brothers. There was no effect for the dummy variable died before father or the country code variable. Historic time periods 1 and 2 showed no significant results, but time period 3 showed a negative effect (odds ratio of 0.372 and a significant value $\mathrm{p}=0.011$ ) compared to time period 4 .

\section{Hypothesis 4c) Sons with a birth order of 3 or higher will be more likely to obtain high}

\section{Church titles than first and second born sons.}

This hypothesis was tested using a binary logistic regression model within the generalized linear model framework with a dummy variable for high rank in the church identified as Abbot (1), Bishop (5), Archbishop (6), Pope (7), Dean (11), and Patriarch (16) as the dependent variable. The results are shown in Table 7.5. First and second born sons showed a negative effect (odds ratio of 0.136 and 0.552 respectively). This indicates 
that first and second born sons were 0.13 and 0.05 times respectively less likely to hold a high title in the Church. The same model indicated that sons with a birth order of 3 and up had an odds ratio of $3.043(\mathrm{p}=0.000)$. This indicates that these sons were nearly 3 times as likely to attain high rank in the Church (Abbot, Bishop, Archbishop, Pope, Dean, and Patriarch) when compared to their older brothers.

Table 7.5. Binary logistic regression model showing the results for independent variable sons and birth order and dependent variable attain high rank in the Church.

\begin{tabular}{lrrrc}
\hline Variable & Estimate & SE & $p$ & Odds Ratio \\
\hline First born son & -1.995 & 0.475 & 0.000 & 0.136 \\
Second born son & -0.594 & 0.303 & 0.050 & 0.552 \\
Died before father (N) & 0.029 & 0.293 & 0.921 & 1.029 \\
Died before father (Y) & -1.326 & 0.569 & 0.020 & 0.266 \\
Historic time period 1 & -18.522 & 5807.063 & 0.997 & 0.000 \\
Historic time period 2 & 0.018 & 0.354 & 0.959 & 1.018 \\
Historic time period 3 & -0.954 & 0.389 & 0.014 & 0.385 \\
& & & & \\
Birth order 3 and up sons & 1.113 & 0.267 & 0.000 & 3.043 \\
Died before father (N) & 0.000 & 0.291 & 0.999 & 1.000 \\
Died before father (Y) & -1.358 & 0.567 & 0.017 & 0.257 \\
Country Code & 0.216 & 0.296 & 0.467 & 1.241 \\
Historic time period 1 & -18.551 & 5871.188 & 0.997 & 0.000 \\
Historic time period 2 & -0.024 & 0.352 & 0.945 & 0.976 \\
Historic time period 3 & -0.989 & 0.388 & 0.011 & 0.372 \\
\hline
\end{tabular}

\section{Hypothesis 5a: First and second born daughters will be less likely to join the Church}

than their younger sisters. Daughters with birth orders 3 and higher will be more likely to enter the church.

This hypothesis was also tested using a binary logistic regression model within the generalized linear model framework. The data were first divided by sex $(0=$ female). The dependent variable was entry into the Church $(0=\mathrm{No}, 1=\mathrm{Yes})$. The covariates were first and second born daughters, died before father $(0=$ No, $1=$ Yes $)$, country code (1=England, 2=France), and historic time period (Period 1: 1000-1066, Period 2: 1066- 
1154, Period 3: 1155-1215, Period 4: 1216-1300). Table 7.6 presents the results from this analysis. There was a negative effect (with an odds ratio of 0.466) for first born daughters joining the Church ( $\mathrm{p}=0.017)$. The results were similar for second born daughters with a negative effect (odds ratio $0.321 \mathrm{p}=0.005$ ) indicating that first born daughters were 0.46 times less likely to join the church while second born daughters were 0.32 times less likely to join the Church than their younger sisters. The same analysis revealed that daughters with a birth order of 3 and higher had an odds ratio of 2.546 and a p value of 0.000. This indicates that daughters with a birth order of 3 and above were nearly 2.5 times more likely to enter the Church than their older sisters.

Table 7.6. Binary logistic regression model showing the results for independent variables daughters and birth order and the dependent variable enter Church.

\begin{tabular}{lcccc}
\hline Variable & Estimate & $\mathrm{SE}$ & $p$ & Odds Ratio \\
\hline First born daughters & -0.765 & 0.321 & 0.017 & 0.466 \\
Second born daughters & -1.136 & 0.404 & 0.005 & 0.321 \\
$\quad$ Died before father (N) & -0.060 & 0.229 & 0.794 & 0.942 \\
Died before father (Y) & -0.731 & 0.431 & 0.089 & 0.481 \\
Country code & -0.470 & 0.321 & 0.143 & 0.625 \\
Historic time period 1 & -0.015 & 0.770 & 0.984 & 0.985 \\
Historic time period 2 & -1.421 & 0.602 & 0.018 & 0.241 \\
Historic time period 3 & -0.440 & 0.275 & 0.110 & 0.644 \\
& & & & \\
Birth order 3 and up daughters & 0.935 & 0.264 & 0.000 & 2.546 \\
Died before father (N) & -0.057 & 0.229 & 0.804 & 0.945 \\
Died before father (Y) & -0.726 & 0.431 & 0.092 & 0.484 \\
Country code & -0.455 & 0.321 & 0.157 & 0.634 \\
Historic time period 1 & 0.059 & 0.771 & 0.991 & 1.009 \\
Historic time period 2 & -1.424 & 0.602 & 0.018 & 0.241 \\
Historic time period 3 & -0.443 & 0.275 & 0.108 & 0.241 \\
\hline
\end{tabular}




\section{Hypothesis 5b: Daughters with a birth order of 3 or higher were more likely to obtain high Church titles than first and second born daughters.}

A binary logistic regression model within the generalized linear model framework was also used to test hypothesis $5 \mathrm{c}$. The data were selected for females ( $0=$ female). The dependent variable was obtain a high church title $(0=\mathrm{No}, 1=\mathrm{Yes})$. High titles were identified as an Abbess or Prioress (2). The covariates were first and second born, died before father $(0=\mathrm{No}, 1=\mathrm{Yes})$, country code (1=England, $2=$ France), and historic time period (Period 1: 1000-1066, Period 2: 1066-1154, Period 3: 1155-1215, Period 4: 12161300). The results (see Table 7.7) show a negative effect for both first and second born daughters (odds ratio of 0.256 and 0.317 respectively). This indicates that first and second born daughters were 0.25 and 0.31 times respectively less likely to hold a high title in the Church. The same model indicated that daughters with a birth order of 3 and above had an odds ratio of 3.578 and a significance of 0.004 . This means that daughters with a birth order of 3 and higher were 3.5 times more likely to hold the title of Abbess or Prioress than their older sisters. 
Table 7.7. Binary logistic regression model showing the results for independent variables daughters and birth order and the dependent variable obtain Church titles.

\begin{tabular}{lrrrc}
\hline Variable & Estimate & $\mathrm{SE}$ & $p$ & Odds Ratio \\
\hline First born daughters & -1.363 & 0.609 & 0.025 & 0.256 \\
Second born daughters & -1.150 & 0.609 & 0.059 & 0.317 \\
Died before father (N) & 0.649 & 0.379 & 0.087 & 1.913 \\
Died before father (Y) & -0.650 & 0.787 & 0.409 & 0.522 \\
Country code & 0.755 & 0.536 & 0.158 & 0.470 \\
Historic time period 1 & 0.291 & 1.065 & 0.785 & 1.337 \\
Historic time period 2 & -0.828 & 0.743 & 0.265 & 0.437 \\
Historic time period 3 & -1.416 & 0.608 & 0.020 & 0.243 \\
& & & & \\
Daughters birth order 3 and up & 1.275 & 0.448 & 0.004 & 3.578 \\
Died before father (N) & 0.645 & 0.379 & 0.089 & 1.905 \\
Died before father (Y) & -0.658 & 0.787 & 0.403 & 0.518 \\
Country code & -0.735 & 0.536 & 0.170 & 0.480 \\
Historic time period 1 & 0.276 & 1.063 & 0.067 & 1.318 \\
Historic time period 2 & -0.830 & 0.743 & 0.264 & 0.436 \\
Historic time period 3 & -1.417 & 0.608 & 0.020 & 0.242 \\
\hline
\end{tabular}

Hypothesis 6: First and second born sons will have larger estates than younger born

sons. Sons with a birth order of 3 and up will have smaller estates than their older

brothers.

Hypotheses 6a was examined using ordinal regression in the generalized linear model framework. The dependent variable was estate size $(0=$ unknown size, $1=$ small estate, $2=$ large estate, $3=$ grandiose estate). The predictors were first and second born sons, and the covariates were died before father $(0=\mathrm{No}, 1=\mathrm{Yes})$, country code (1=England, 2=France), and historic time period (Period 1:1000-1066, Period 2: 10661151, Period 3: 1155-1215, Period 4: 1216-1300).

Table 7.8 shows a positive correlation for first born $(0.557,0.000)$ and second born sons $(0.347,0.015)$. This indicates that first born sons were 0.55 times as likely and second born sons were 0.34 times as likely to have a large estate as their younger 
brothers. Sons with a birth order of three or higher show a negative correlation $(-0.443$, $\mathrm{p}=0.000)$ in relation to estate size.

Table 7.8. Ordinal regression model showing the results for independent variables sons and birth order and outcome variable estate size.

\begin{tabular}{lccc}
\hline Variable & Estimate & SE & $p$ \\
\hline First born & 0.557 & 0.1318 & 0.000 \\
Second born & 0.347 & 0.1428 & 0.015 \\
$\quad$ Died before father & -0.686 & 0.5011 & 0.000 \\
Country code & -0.325 & 0.1497 & 0.030 \\
Historic time period 1 & 0.654 & 0.3188 & 0.040 \\
Historic time period 2 & 0.482 & 0.1826 & 0.008 \\
Historic time period 3 & 0.230 & 0.1433 & 0.109 \\
Estate size (0) & -1.180 & 0.2078 & 0.000 \\
Estate size (1) & 2.460 & 0.2272 & 0.000 \\
Estate size (2) & 4.659 & 0.3734 & 0.000 \\
& & & 0.000 \\
Birth order 3 and up & -0.443 & 0.1170 & 0.000 \\
Died before father & -0.684 & 0.0510 & 0.035 \\
Country code & -0.316 & 0.1497 & 0.039 \\
Historic time period 1 & 0.656 & 0.3180 & 0.005 \\
Historic time period 2 & 0.510 & 0.1820 & 0.097 \\
Historic time period 3 & 0.238 & 0.1431 & 0.000 \\
Estate size (0) & -1.617 & 0.2102 & 0.000 \\
Estate size (1) & 2.013 & 0.2217 & 0.000 \\
Estate size (2) & 4.212 & 0.3700 & \\
\hline
\end{tabular}




\section{Chapter Eight: Marriage}

\section{Introduction}

In chapters 6 and 7 we examined child survival and outcomes related to wealth and status respectively as measures of parental investment. In this chapter we will examine consanguineous marriage as an additional measure of parental investment. Consanguineous marriage has been used historically to cement family connections and to maintain the status and wealth within a family or lineage. The maintenance of status and wealth was especially important in the marriages of first and second born children (both sons and daughters). As a result, it might be expected that older children with a birth order of one or two would be more likely to marry close kin (consanguineous relatives) than their younger siblings. By arranging the marriages of first and second born (who were likely to inherit significant amounts of the family wealth) to close family members, parents were not only able to secure the wealth and status of the family, but they were also able to create powerful and durable alliances backed by the creation of new kinship ties through marriage.

Younger children, those with a birth order of three or higher, will be less likely to marry consanguineous kin. These children will be less likely to inherit important titles, or large tracts of land, so will not have as great an impact on the family status. However, in order to secure alliances, children with later birth order may marry affinal kin. The connections between the families have already been established and an additional marriage may help cement that connection, i.e. two brothers from one family could marry two sisters from another family. There may be other examples of affinal marriage as well. Louis VII, King of France arranged the marriages of his two daughters, Maria and 
Alix, with his brothers-in-law, the brothers of his second wife, i.e. the girls' uncles by marriage. In another example, Peter, Lord of Cameros, married his oldest sister's stepdaughter, the daughter of James II, King of Aragon and Valencia. This would have made the spouses step-uncle/niece.

In another measure of parental investment, we will examine the age at marriage for children and their respective spouses. First and second born children regardless of gender are predicted to marry a spouse who is the same age or just a few years older. Children with higher birth orders, 3 and above, will be more likely to have a larger age gap between the spouses. This age gap would be at least 5 years but could be more than 20 years in some cases. As birth order increases, the importance of those offspring marrying will decrease. Spouses that may not have acceptable for first or second born children would then become an option for higher born children. In the previous example of Peter, Lord of Cameros, who married his older sister's stepdaughter, the groom was 29 at the time of marriage while the bride was 16 . Peter was the fifth child and third son born to his parents.

By marrying first and second born children to spouses who are relatively close in age, parents could potentially increase the number of grand-offspring produced. When there is a larger age gap in the spouses, there may be a period of waiting as the younger spouse may not be of mature age and able to produce offspring. In this respect, one could almost argue that parents are limiting competition over resources as they are delaying and/or preventing the birth of additional potential heirs. 


\section{Hypothesis 7: First and second born offspring are more likely to marry}

\section{consanguineous kin than younger children. Younger offspring (those with higher}

birth order) will be more likely to marry affinal kin.

This hypothesis was tested using a multinomial logistic regression. In the first analysis, the dependent variables were familial relationship: $0=$ No relation, $1=$ Affinal Kin, 2=Consanguineal Kin. The independent variables were first and second born, died before father $(0=\mathrm{No}, 1=\mathrm{Yes})$, country code ( $1=$ England, $2=$ France $)$, and historic time period (Period 1: 1000-1066, Period 2: 1066-1154, Period 3: 1155-1215, Period 4: 12161300). Table 8.1 indicates that there was no effect of being either first or second born sons and marrying consanguineal or affinal kin. First and second born daughters did have a significantly higher likelihood (odds ratio 4.915 and $3.625, \mathrm{p}=0.010$ and 0.034 ) of marrying consanguineal kin. There were no significant effects of being either first or second born daughters and marrying affinal kin.

Table 8.1. Multinomial logistic regression showing results for effect of birth order and gender on likelihood of marrying consanguineous kin versus affinal kin.

\begin{tabular}{lrrrr}
\hline Variable & Estimate & SE & $p$ & Odds Ratio \\
\hline Consanguineous Kin & & & & \\
First born sons & -1.167 & 0.731 & 0.110 & 0.311 \\
Second born sons & -0.606 & 0.870 & 0.486 & 0.546 \\
$\quad$ Died before father (N) & 18.509 & 6703.414 & 0.998 & 109277299.581 \\
Died before father (Y) & 17.735 & 6703.414 & 0.998 & 50358168.135 \\
Country Code & -0.383 & 1.140 & 0.737 & 0.682 \\
Historic time period 1 & 0.459 & 0.000 & - & 1.582 \\
Historic time period 2 & 0.872 & 0.972 & 0.370 & 2.391 \\
Historic time period 3 & -0.168 & 0.638 & 0.793 & 0.846 \\
\hline
\end{tabular}


Table 8.1. Multinomial logistic regression showing results for effect of birth order and gender on likelihood of marrying consanguineous kin versus affinal kin continued.

\begin{tabular}{|c|c|c|c|c|}
\hline Variable & Estimate & SE & $p$ & Odds Ratio \\
\hline \multicolumn{5}{|l|}{ Affinal Kin } \\
\hline First born sons & -0.187 & 0.300 & 0.533 & 0.829 \\
\hline Second born sons & 0.389 & 0.394 & 0.324 & 1.475 \\
\hline Died before father $(\mathrm{N})$ & -0.833 & 0.449 & 0.064 & 0.435 \\
\hline Died before father (Y) & -0.970 & 0.508 & 0.056 & 0.379 \\
\hline Country Code & 0.813 & 0.477 & 0.088 & 2.255 \\
\hline Historic time period 1 & 18.706 & 8163.119 & 0.998 & 133084469.288 \\
\hline Historic time period 2 & 0.415 & 0.547 & 0.448 & 1.514 \\
\hline Historic time period 3 & -0.865 & 0.285 & 0.002 & 0.421 \\
\hline \multicolumn{5}{|l|}{ Consanguineous Kin } \\
\hline First born daughters & 1.592 & 0.620 & 0.010 & 4.915 \\
\hline Second born daughters & 1.288 & 0.607 & 0.034 & 3.625 \\
\hline Died before father $(\mathrm{N})$ & -0.539 & 0.600 & 0.369 & 0.583 \\
\hline Died before father (Y) & -1.232 & 0.944 & 0.192 & 0.292 \\
\hline Country Code & 0.850 & 0.862 & 0.324 & 2.339 \\
\hline Historic time period 1 & 19.248 & 0.000 & - & 228786160.383 \\
\hline Historic time period 2 & 2.260 & 1.148 & 0.049 & 9.579 \\
\hline Historic time period 3 & -0.714 & 0.594 & 0.229 & 0.489 \\
\hline \multicolumn{5}{|l|}{ Affinal Kin } \\
\hline$\overline{\text { First born daughters }}$ & 0.138 & 0.373 & 0.712 & 1.148 \\
\hline Second born daughters & -0.354 & 0.343 & 0.302 & 0.702 \\
\hline Died before father $(\mathrm{N})$ & -0.997 & 0.381 & 0.009 & 0.369 \\
\hline Died before father (Y) & -1.111 & 0.478 & 0.020 & 0.329 \\
\hline Country Code & 1.336 & 0.601 & 0.026 & 3.803 \\
\hline Historic time period 1 & 17.536 & 0.840 & 0.000 & 41271891.832 \\
\hline Historic time period 2 & 1.483 & 1.023 & 0.147 & 4.404 \\
\hline Historic time period 3 & -0.674 & 0.287 & 0.019 & 0.510 \\
\hline
\end{tabular}

The second multinomial logistic regression also used familial relationship: $0=$ No relation, 1=Affinal Kin, 2=Consanguineal Kin, as the dependent variables. The independent variables were birth order of three and up $(0=\mathrm{No}, 1=\mathrm{Yes})$, died before father $(0=$ No, $1=$ Yes $)$, country code (1=England, $2=$ France $)$, and historic time period (Period 1: 1000-1066, Period 2: 1066-1154, Period 3: 1155-1215, Period 4: 1216-1300). Table 8.2 indicates that there was no significance for sons with a birth order of three and higher of 
marrying consanguineous or affinal kin. Daughters with a birth order of three and above showed no significant results for consanguineal marriage, but there was a significant effect of daughters with a birth order of 3 and above and marrying affinal kin (odds ratio $0.240, \mathrm{p}=0.007)$. This indicates that younger daughters were 0.24 less likely to marry affinal kin than their older sisters.

Table 8.2. Multinomial logistic regression showing results for effect of offspring with birth order of 3 and above and gender on likelihood of marrying consanguineous kin versus affinal kin.

\begin{tabular}{lrrrr}
\hline Variable & Estimate & SE & $p$ & Odds Ratio \\
\hline Consanguineous Kin & & & & \\
\hline Sons third born and up & 0.969 & 0.618 & 0.117 & 2.634 \\
Died before father (N) & 18.476 & 6701.770 & 0.998 & 105663679.784 \\
Died before father (Y) & 17.707 & 6701.770 & 0.998 & 48987694.533 \\
County code & -0.374 & 1.139 & 0.743 & 0.688 \\
Historic time period 1 & 0.488 & 0.000 & - & 1.629 \\
Historic time period 2 & 0.842 & 0.970 & 0.386 & 2.320 \\
Historic time period 3 & -0.185 & 0.637 & 0.772 & 0.831 \\
& & & & \\
Affinal Kin & & & & 0.914 \\
Sons third born and up & -0.030 & 0.274 & 0.052 & 0.419 \\
Died before father (N) & -0.870 & 0.448 & 0.049 & 0.368 \\
Died before father (Y) & -0.999 & 0.508 & 0.088 & 2.257 \\
Country code & 0.814 & 0.477 & 0.998 & 13595566.121 \\
Historic time period 1 & 18.733 & 8184.039 & 0.480 & 1.470 \\
Historic time period 2 & 0.386 & 0.546 & 0.002 & 0.415 \\
Historic time period 3 & -0.879 & 0.285 & & \\
& & & 0.714 & 1.109 \\
Consanguineous Kin & & & 0.009 & 0.371 \\
Daughters third born and up & 0.103 & 0.281 & 0.021 & 0.333 \\
Died before father (N) & -0.990 & 0.380 & 0.025 & 3.851 \\
Died before father (Y) & -1.101 & 0.477 & 0.000 & 45301201.955 \\
County code & 1.348 & 0.601 & 0.149 & 0.382 \\
Historic time period 1 & 17.629 & 0.833 & 0.018 & 0.508 \\
\hline Historic time period 2 & 1.477 & 1.023 & & \\
Historic time period 3 & -0.677 & 0.287 & &
\end{tabular}


Table 8.2. Multinomial logistic regression showing results for effect of offspring with birth order of 3 and above and gender on likelihood of marrying consanguineous kin versus affinal kin continued.

\begin{tabular}{lrrrr}
\hline Variable & Estimate & SE & $p$ & Odds Ratio \\
\hline Affinal Kin & & & & \\
\hline Daughters third born and up & -1.426 & 0.525 & 0.007 & 0.240 \\
Died before father (N) & -0.542 & 0.598 & 0.365 & 0.582 \\
Died before father (Y) & -1.234 & 0.943 & 0.191 & 0.291 \\
County code & 0.835 & 0.861 & 0.332 & 2.305 \\
Historic time period 1 & 19.306 & 0.000 & - & 242401863.484 \\
Historic time period 2 & 2.263 & 1.147 & 0.049 & 9.614 \\
Historic time period 3 & -0.712 & 0.593 & 0.230 & 0.490 \\
\hline
\end{tabular}

\section{Hypothesis 8: Later born daughters will be more likely to have a spouse 5+ years} older than themselves.

This hypothesis was tested using two separate binary logistic regression models within the generalized linear model framework. A dummy variable was created for age of spouse at marriage, specifically whether the spouse was 5 years older than the ego $(0=\mathrm{No}$, $1=$ Yes $)$. The independent variables were first and second born, died before father $(0=$ No, 1=Yes), country code (1=England, 2=France), and historic time period (Period 1: 10001066, Period 2: 1066-1154, Period 3: 1155-1215, Period 4: 1216-1300). A second analysis was run for daughters with birth order 3 and higher. Table 8.3 indicates there was no effect or significant results for any of these variables for either first born and second born daughter or for daughters with a birth order of three and higher. 
Table 8.3. Binary logistic regression using independent variables daughters and birth order and dependent variable spouse less than 5 years older.

\begin{tabular}{lccc}
\hline Variable & Estimate & SE & $p$ \\
\hline First born & 0.418 & 0.2851 & 0.143 \\
Second born & 0.289 & 0.3232 & 0.371 \\
$\quad$ Died before father & 0.577 & 0.4006 & 0.000 \\
Country code & -0.072 & 0.3387 & 0.030 \\
Historic time period 1 & -1.803 & 1.1736 & 0.125 \\
Historic time period 2 & -0.733 & 0.4002 & 0.067 \\
Historic time period 3 & 0.473 & 0.2888 & 0.101 \\
& & & \\
Birth order 3 and up & -0.343 & 0.2419 & 0.157 \\
Died before father & 0.584 & 0.4005 & 0.145 \\
Country code & -0.086 & 0.3387 & 0.799 \\
Historic time period 1 & -1.773 & 1.1693 & 0.129 \\
Historic time period 2 & -0.727 & 0.3998 & 0.069 \\
Historic time period 3 & 0.462 & 0.2881 & 0.108 \\
\hline
\end{tabular}




\section{Chapter Nine Results: Reproductive Success}

\section{Introduction}

In previous chapters we examined various outcomes of parental investment, child survival, child outcomes related to wealth and status, and consanguineous marriage. In this chapter we will examine one of the most significant measures of parental investment, namely reproductive success (RS). Evolutionary theory indicates that the effects of parental investment are likely to be seen more clearly in the numbers of offspring produced by males than by females. Males who are first born or second sons will receive more parental investment than sons who have higher birth orders. In terms of reproductive success this translates into the birth of more offspring and grand-offspring. Sons with older brothers will see a reduction in the number of their progeny. Daughters may also see the effects of parental investment on their number of progeny, but the effects for daughters will not be as great as the effects for sons given limitations in female RS as compared to male RS, since female RS is limited by a single woman's ability to bear children while male RS is limited by number of spouses, in this case with higher status men being more likely to marry early and/or remarry more quickly in this context. First and second born daughters will receive more parental investment than their younger sisters. This means that first and second born daughters will produce more children and grandchildren than their younger sisters.

This chapter examines the effects of parental investment on reproductive success, as proxied by children born (or at least recorded) over the course of four generations (children, grandchildren, great-grandchildren, and great-great grandchildren). These measures get increasingly better as proxies for long-term reproductive success over the 
generations, though the quality of the data may become less reliable over time as well. It is predicted that first born sons will have significantly more children, grandchildren, great-grandchildren, and great-great grandchildren than their younger siblings. Second born sons will also have more issue then their younger siblings, but not as many as their older brothers. Sons with higher birth orders (three and above) will have significantly fewer offspring than their older brothers. First born daughters will also produce more offspring than their younger sisters, but not as many offspring as their older brothers. Second born daughters will produce more children than their youngers sisters (with a birth order of three and above), but will not produce as many offspring as their older sisters.

Hypothesis 9a: First born and second born sons will produce more children, grandchildren, great-grandchildren, and great-great-grandchildren than their younger brothers.

Hypothesis 9b: First and second born daughters will produce more children, grandchildren, great-grandchildren, and great-great-grandchildren than their younger sisters, though this effect will be weaker than the effect in sons.

To test these hypotheses, a series of poisson loglinear generalized linear models were used. In the first analysis, the number of children born was used as the dependent variable. The independent variables were first and second born, died before father $(0=\mathrm{No}$, 1=Yes), country code (1=England, 2=France), and historic time period (Period 1: 10001066, Period 2: 1066-1154, Period 3:1155-1214, Period 4: 1216-1300). Table 9.1 indicates a positive correlation between first and second born males and the total number of children born. First born sons had a positive effect of 0.599 and a significance of 
0.000. Second born sons also had a positive effect (0.458) and a significance of 0.000 .

This indicates that first born sons would have nearly 0.5 more children than their younger brothers while second born sons would have 0.45 more children than their younger brothers. There was also a positive correlation for first and second born daughters $(0.219$, $\mathrm{p}=0.000$ and $0.282 \mathrm{p}=0.000$ respectively), indicating that first and second born daughters would have 0.21 and 0.28 more children than their younger sisters.

Table 9.1. Poisson loglinear generalized linear model showing the effects of independent variables first and second born sons and daughters on the outcome variable number of children.

\begin{tabular}{lccc}
\hline Variable & Estimate & SE & $p$ \\
\hline First born sons & 0.599 & 0.0953 & 0.000 \\
Second born sons & 0.458 & 0.0587 & 0.000 \\
$\quad$ Died before father (N) & 1.548 & 0.0911 & 0.000 \\
Died before father (Y) & -0.104 & 0.1400 & 0.459 \\
Country code & 0.067 & 0.0571 & 0.240 \\
Historic time period 1 & 0.280 & 0.1094 & 0.010 \\
Historic time period 2 & 0.225 & 0.0624 & 0.000 \\
Historic time period 3 & 0.019 & 0.0561 & 0.735 \\
& & & \\
First born daughters & 0.219 & 0.0553 & 0.000 \\
Second born daughters & 0.282 & 0.0582 & 0.000 \\
Died before father (N) & 1.215 & 0.0636 & 0.000 \\
Died before father (Y) & -0.443 & 0.1348 & 0.001 \\
Country code & -0.005 & 0.0598 & 0.931 \\
Historic time period 1 & 0.494 & 0.0598 & 0.003 \\
Historic time period 2 & 0.321 & 0.0745 & 0.000 \\
Historic time period 3 & 0.202 & 0.0531 & 0.000 \\
\hline
\end{tabular}

In the second analysis, the dependent variable was total number of children born. The independent variables included were birth order of three or higher $(0=\mathrm{No}, 1=\mathrm{Yes})$, died before father $(0=$ No, $1=$ Yes $)$, country code $(1=$ England, $2=$ France $)$, and historic time period (Period 1: 1000-1066, Period 2: 1066-1154, Period 3: 1155-1215, Period 4: 12161300). Children with a birth order of three or higher (both male and female) saw a 
negative effect in the total number of children produced. Table 9.2 indicates for third born (or higher) males there was a negative coefficient of -0.524 with a significance of 0.000. This means that sons with later birth orders were likely to have 0.52 fewer children than their older siblings. Daughters with a birth order of three or higher also saw a negative effect in the total number of children born. For third born (or higher) daughters there was a negative coefficient -0.276 with a significance of 0.000 . This means that daughters with later birth orders were likely to have 0.27 fewer children than their older sisters.

Table 9.2. Poisson loglinear generalized linear model showing the effects of independent variable sons and daughters with a birth order of 3 and up on the outcome variable number of children.

\begin{tabular}{lccc}
\hline Variable & Estimate & SE & $p$ \\
\hline Sons & & & \\
Birth order 3 and up & -0.524 & 0.0480 & 0.000 \\
Died before father (N) & 1.558 & 0.0910 & 0.000 \\
Died before father (Y) & -0.094 & 0.1400 & 0.501 \\
Country code & 0.065 & 0.0571 & 0.253 \\
Historic time period 1 & 0.283 & 0.1094 & 0.010 \\
Historic time period 2 & 0.239 & 0.0623 & 0.000 \\
Historic time period 3 & 0.034 & 0.0560 & 0.545 \\
& & & \\
Daughters & & & 0.000 \\
Birth order 3 and up & -0.276 & 0.0455 & 0.000 \\
Died before father (N) & 1.209 & 0.0636 & 0.001 \\
Died before father (Y) & -0.449 & 0.1347 & 0.004 \\
Country code & -0.013 & 0.0598 & 0.000 \\
Historic time period 1 & 0.477 & 0.1660 & 0.000 \\
Historic time period 2 & 0.316 & 0.0745 & \\
Historic time period 3 & 0.198 & 0.0531 & \\
\hline
\end{tabular}

In the third analysis, the dependent variable was the total number of grandchildren born. The independent variables were first and second born, died before father $(0=\mathrm{No}$, 1=Yes), country code (1=England, 2=France), and historic time period (Period 1: 1000- 
1066, Period 2: 1066-1154, Period 3: 1155-1215, Period 4: 1216-1300). Table 9.3 shows the results from this analysis. There was a positive effect for first born males $(0.627)$ with a significance of $p=0.000$. This indicates that first born sons are likely to have 0.62 more grandchildren than their younger brothers. There was also a positive effect for second born sons $(0.455)$ with a significance of 0.000 . Second born sons were therefore more likely to have 0.45 more grandchildren than their younger siblings. First and second born daughters also had a positive, statistically significant result $(0.106, \mathrm{p}=0.015$ and 0.215 , $\mathrm{p}=0.000$ ). This suggests that first and second born daughters will have 0.16 and 0.21 more grandchildren than their younger sisters.

Table 9.3. Poisson loglinear generalized linear model showing the effects of independent variable first and second born sons and daughters on the outcome variable number of grandchildren.

\begin{tabular}{lccc}
\hline Variable & Estimate & SE & $p$ \\
\hline Sons & & & \\
First born sons & 0.627 & 0.0405 & 0.000 \\
Second born sons & 0.455 & 0.0456 & 0.000 \\
$\quad$ Died before father (N) & 1.799 & 0.0779 & 0.000 \\
Died before father (Y) & -0.137 & 0.1214 & 0.258 \\
Country code & -0.045 & 0.0455 & 0.323 \\
Historic time period 1 & 0.382 & 0.0809 & 0.000 \\
Historic time period 2 & 0.164 & 0.0494 & 0.001 \\
Historic time period 3 & 0.115 & 0.0421 & 0.006 \\
& & & \\
Daughters & & & 0.015 \\
First born daughters & 0.106 & 0.0437 & 0.000 \\
Second born daughters & 0.215 & 0.0454 & 0.000 \\
Died before father (N) & 1.563 & 0.0563 & 0.033 \\
Died before father (Y) & 0.204 & 0.0959 & 0.005 \\
Country code & -0.015 & 0.0467 & 0.000 \\
Historic time period 1 & 0.399 & 0.1417 & 0.000 \\
Historic time period 2 & 0.216 & 0.0618 & \\
Historic time period 3 & 0.279 & 0.0404 & \\
\hline
\end{tabular}


In the fourth analysis, the dependent variable was the total number of grandchildren born. The independent variables were birth order of three or higher $(0=$ No, $1=$ Yes $)$, died before father $(0=$ No, $1=$ Yes $)$, country code $(1=$ England, $2=$ France $)$, and historic time period (Period 1: 1000-1066, Period 2: 1066-1154, Period 3: 1155-1215, Period 4: 1216-1300. See Table 9.4 below for the results of this analysis. For sons with a birth order of 3 and above there was a negative effect with a coefficient of -0.539 and a significance of $p=0.000$. This indicates that sons with a birth order of three and above were likely to have 0.53 fewer grandchildren than their older brothers. There was also a negative effect $(-0.226, \mathrm{p}=0.000)$ for daughters with a birth order of 3 and above, meaning that daughters with a birth order of 3 and above were likely to have 0.26 fewer grandchildren than their older sisters.

Table 9.4. Poisson loglinear generalized linear model showing the effects of independent variable sons and daughters with a birth order of 3 and up on the outcome variable number of grandchildren.

\begin{tabular}{lccc}
\hline Variable & Estimate & SE & $p$ \\
\hline Sons & & & \\
Birth order 3 and up & -0.539 & 0.0371 & 0.000 \\
Died before father (N) & 1.812 & 0.0778 & 0.000 \\
Died before father (Y) & -0.125 & 0.1213 & 0.302 \\
Country code & -0.045 & 0.0455 & 0.318 \\
Historic time period 1 & 0.383 & 0.0809 & 0.000 \\
Historic time period 2 & 0.181 & 0.0493 & 0.000 \\
Historic time period 3 & 0.133 & 0.0420 & 0.002 \\
& & & \\
Daughters & & & 0.000 \\
Birth order 3 and up & -0.226 & 0.0354 & 0.000 \\
Died before father (N) & 1.552 & 0.0563 & 0.045 \\
Died before father (Y) & 0.192 & 0.0959 & 0.638 \\
Country code & -0.022 & 0.0467 & 0.010 \\
Historic time period 1 & 0.365 & 0.1413 & 0.001 \\
Historic time period 2 & 0.202 & 0.0618 & 0.000 \\
Historic time period 3 & 0.270 & 0.0404 & \\
\hline
\end{tabular}


A fifth analysis used a general linear model to examine the effects of birth order and the number of great-grandchildren. The dependent variable was the total number of great-grandchildren born. The independent variables were first and second born, died before father $(0=$ No, $1=$ Yes $)$, country code $(1=$ England, $2=$ France $)$, and historic time period (Period 1: 1000-1066, Period 2: 1066-1154, Period 3: 1155-1215, Period 4: 12161300).

As seen in Table 9.5, the results show a positive correlation for both first and second born sons and the number of great-grandchildren born. First born sons had a positive effect of 0.484 and a significance of 0.000 . This means that first born sons were likely to have 0.48 more great-grandchildren than their younger brothers. There was a positive effect $(0.310 \mathrm{p}=0.000)$ for second born sons. There appeared to be a strong correlation between first and second born sons and the number of great-grandchildren born, though it is hard to know if this effect may be due to the ability to follow up reproduction in the database. This could therefore be a data artifact, with the lack of information on all great-grandchildren born (especially under-reporting of females), especially for younger sons or the offspring of daughters.

First born daughters had a negative, although significant effect $(-0.104 \mathrm{p}=0.004)$ of birth order on the total number of great-grandchildren born overall, with first born daughters having fewer great-grandchildren than their younger sisters. Second born daughters had a positive effect $(0.129, \mathrm{p}=0.000)$ indicating that daughters with a birth order of 2 would have 0.12 more great-grandchildren than their first born sisters. 
Table 9.5. Poisson loglinear generalized linear model showing the effects of independent variables first and second born sons and daughters on the outcome variable number of great-grandchildren.

\begin{tabular}{lccc}
\hline Variable & Estimate & SE & $p$ \\
\hline Sons & & & \\
\hline First born sons & 0.484 & 0.0777 & 0.000 \\
Second born sons & 0.310 & 0.0349 & 0.000 \\
$\quad$ Died before father (N) & 2.363 & 0.0759 & 0.000 \\
Died before father (Y) & 0.304 & 0.1061 & 0.004 \\
Country code & -0.090 & 0.0356 & 0.011 \\
Historic time period 1 & 0.503 & 0.0623 & 0.000 \\
Historic time period 2 & 0.268 & 0.0384 & 0.000 \\
Historic time period 3 & 0.420 & 0.0306 & 0.000 \\
& & & \\
Daughters & & & 0.004 \\
First born daughters & -0.104 & 0.0359 & 0.000 \\
Second born daughters & 0.129 & 0.0358 & 0.000 \\
Died before father (N) & 1.696 & 0.0466 & 0.000 \\
Died before father (Y) & 0.597 & 0.0709 & 0.000 \\
Country code & -0.144 & 0.0387 & 0.000 \\
Historic time period 1 & 0.640 & 0.1046 & 0.005 \\
Historic time period 2 & 0.146 & 0.0524 & 0.000 \\
Historic time period 3 & 0.491 & 0.0306 & \\
\hline
\end{tabular}

Table 9.6 shows the results of a sixth general linear model. In this analysis, the total number of great-grandchildren born was used as the dependent variable. The independent variables were birth order of 3 and up $(0=$ No, $1=$ Yes $)$, died before father $(0=$ No, $1=$ Yes $)$, country code $(1=$ England, $2=$ France $)$, and historic time period (Period 1 : 1000-1066, Period 2: 1066-1154, Period 3: 1155-1215, Period 4: 1216-1300). For sons with a birth order of three and higher, there was a negative and statistically significant effect $(-0.398 \mathrm{p}=0.000)$. This indicates that sons with a birth order of three or higher were likely to have 0.39 fewer children than their older brothers. Daughters with a birth order of three and above also showed a negative effect $(-0.110, \mathrm{p}=0.000)$ on total number of great-grandchildren born. 
Table 9.6. Poisson loglinear generalized linear model showing the effects of independent variable sons and daughters with a birth order of 3 and up on the outcome variable number of great-grandchildren.

\begin{tabular}{lccc}
\hline Variable & Estimate & SE & $p$ \\
\hline Sons & & & \\
Birth order 3 and up & -0.398 & 0.0279 & 0.000 \\
Died before father (N) & 2.376 & 0.0759 & 0.000 \\
Died before father (Y) & 0.315 & 0.1061 & 0.003 \\
Country code & -0.089 & 0.0356 & 0.012 \\
Historic time period 1 & 0.502 & 0.0623 & 0.000 \\
Historic time period 2 & 0.284 & 0.0384 & 0.000 \\
Historic time period 3 & 0.437 & 0.0305 & 0.000 \\
& & & \\
Daughters & & & 0.000 \\
Birth order 3 and up & -0.110 & 0.0281 & 0.000 \\
Died before father (N) & 1.679 & 0.0466 & 0.000 \\
Died before father (Y) & 0.577 & 0.0709 & 0.000 \\
Country code & -0.150 & 0.0387 & 0.000 \\
Historic time period 1 & 0.577 & 0.1043 & 0.017 \\
Historic time period 2 & 0.125 & 0.0523 & 0.000 \\
Historic time period 3 & 0.479 & 0.0306 & \\
\hline
\end{tabular}

In a seventh general linear model, the effects of birth order on the number of great-great grandchildren born was examined. The total number of great-great grandchildren was used as the dependent variable. The independent variables were first and second birth order, died before father $(0=$ No, $1=$ Yes $)$, country code $(1=$ England, 2=France), and historic time period (Period 1: 1000-1066, Period 2: 1066-1154, Period 3: 1155-1215, Period 4: 1216-1300). As seen in Table 9.7, first born sons saw a strong positive effect of 0.407 and a statistically significant $p$ value of 0.000 . This indicates that first born sons were likely to have 0.40 more great-great grandchildren than their younger brothers. Results for second born sons also indicated a positive significant effect $(0.291$, $\mathrm{p}=0.000$ ) for the number of great-great grandchildren born. First born females did not show any significant effects on the number of great-great grandchildren (see Table 9.7). 
However, there was a strong statistically significant effect $(0.077, \mathrm{p}=0.007$ for second born daughters.

Table 9.7. Poisson loglinear generalized linear model showing the effects of independent variables first and second born sons and daughters and the outcome variable number of great-great-grandchildren.

\begin{tabular}{lccc}
\hline Variable & Estimate & SE & $p$ \\
\hline Sons & & & \\
\hline First born sons & 0.407 & 0.0239 & 0.000 \\
Second born sons & 0.291 & 0.0269 & 0.000 \\
Died before father (N) & 2.363 & 0.0589 & 0.000 \\
Died before father (Y) & 0.180 & 0.0852 & 0.034 \\
Country code & -0.134 & 0.0282 & 0.000 \\
Historic time period 1 & 0.401 & 0.0513 & 0.000 \\
Historic time period 2 & 0.363 & 0.0292 & 0.000 \\
Historic time period 3 & 0.427 & 0.0240 & 0.000 \\
& & & \\
Daughters & & & 0.102 \\
First born daughters & -0.044 & 0.0272 & 0.007 \\
Second born daughters & 0.077 & 0.0283 & 0.000 \\
Died before father (N) & 1.798 & 0.0374 & 0.000 \\
Died before father (Y) & 0.751 & 0.0548 & 0.000 \\
Country code & -0.105 & 0.0296 & 0.000 \\
Historic time period 1 & 0.739 & 0.0781 & 0.000 \\
Historic time period 2 & 0.421 & 0.0365 & 0.000 \\
Historic time period 3 & 0.460 & 0.0242 & \\
\hline
\end{tabular}

In the final poisson loglinear general linear model for this chapter, the relationship between the total number of great-great grandchildren born and birth order of 3 and up was examined. The dependent variable was the total number of great-great grandchildren born. The independent variables were birth order of three and up $(0=\mathrm{No}, 1=\mathrm{Yes})$, died before father $(0=$ No, $=$ Yes $)$, country code $(1=$ England, $2=$ France $)$, and historic time period (Period 1: 1000-1066, Period 2: 1066-1154, Period 3: 1155-1215, Period 4: 12161300). 
As seen in Table 9.8, there was a negative correlation for birth order of three and up and the total number of great-great grandchildren born. These younger sons showed a negative effect of -0.345 and a $p$ value of 0.000 . This indicates that sons with a birth order of three and higher would have on average 0.34 fewer great-great grandchildren than their older brothers. Daughters with a birth order of three and higher also saw a negative correlation $(-0.111 \mathrm{p}=0.000)$ between birth order and the number of great-great grandchildren born, which was significant.

Table 9.8. Poisson loglinear generalized linear model showing the independent variable sons and daughters with a birth order of 3 and up and the outcome variable number of great-great-grandchildren.

\begin{tabular}{lccc}
\hline Variable & Estimate & SE & $p$ \\
\hline Sons & & & \\
Birth order 3 and up & -0.345 & 0.0216 & 0.000 \\
Died before father (N) & 2.373 & 0.0589 & 0.000 \\
Died before father (Y) & 0.188 & 0.0852 & 0.027 \\
Country code & -0.135 & 0.0282 & 0.000 \\
Historic time period 1 & 0.401 & 0.0513 & 0.000 \\
Historic time period 2 & 0.375 & 0.0291 & 0.000 \\
Historic time period 3 & 0.439 & 0.0239 & 0.000 \\
& & & \\
Daughters & & & 0.000 \\
Birth order 3 and up & -0.111 & 0.0218 & 0.000 \\
Died before father (N) & 1.783 & 0.0374 & 0.000 \\
Died before father (Y) & 0.736 & 0.0548 & 0.000 \\
Country code & -0.109 & 0.0296 & 0.000 \\
Historic time period 1 & 0.697 & 0.0778 & 0.000 \\
Historic time period 2 & 0.400 & 0.0365 & 0.000 \\
Historic time period 3 & 0.448 & 0.0242 & \\
\hline
\end{tabular}




\section{Chapter Ten: Discussion and Conclusions}

Parental investment theory is one aspect of evolutionary theory that seeks to explain how parents, including human parents, allocate their time and energy to invest in offspring. Parent investment theory predicts that in some ecological settings human parents will invest in their children differently based on birth order and gender. Deciding which child to invest in and how much may increase the quality of the offspring and the parent's overall reproductive success. This dissertation has examined parental investment among the aristocracy of England and France in the $11^{\text {th }}$ through $13^{\text {th }}$ centuries focused on the outcomes of child survival, social status and wealth, marriage, and reproductive success.

\section{Child survival}

As discussed in Chapter 6, child survival will be impacted by a number of factors. This study examined child survival using birth order and gender as indicators of parental investment. Historic data has certain limitations. Birth information can be especially difficult to obtain. Birth dates may not be recorded due to high infant mortality rates, meaning that only children who survived to a certain age would have been recorded, or the birth of certain children will be recorded while others will not. For example, males may be more likely to have their births or birth dates recorded than females. As a result of this, it was difficult to use birth date to assess child survival. Instead larger categories were used, such as survival to age 5 and survival to age 15 , as well as controls for whether the child died before their mother or father. While children who died at very young ages - under one, for instance - may not be recorded consistently in the records, it 
is more reasonable to assume that children who survived past the first few months of life would have been recorded. Analyses focused on survival to age 5 and age 15 aimed to capture effects of gender and birth order on child survival in the shorter and longer term.

Three sets of hypotheses were generated relating to child survival: 1a) First and second born sons will be more likely to survive to age 5 than their younger brothers. 2a) First and second born daughters are more likely to survive to age than their younger sisters. 1b) First and second born sons will be more likely to survive to age 15 than their younger brothers. 2b) First and second born daughters are more likely to survive to age 15 than their younger sisters. 3a) First and second born sons will be more likely to survive to age 5 than their sisters regardless of birth order. 3b) First and second born daughters will be more likely to survive to age 5 and 15 than younger born sons (birth order of 3 and higher).

Hypothesis 1a was supported. First and second born sons were more likely to survive to age 5 than their younger brothers. Hypothesis 2a was accepted. First and second born daughters did have a greater likelihood of surviving to age 5 than their younger sisters.

The predictions associated with hypothesis $1 \mathrm{~b}$ were supported. First and second born sons were more likely to survive to age 15 than their younger brothers. Hypothesis $2 \mathrm{~b}$ was rejected. There was no statistical significance for first and second born daughters surviving to age 15 more readily than their younger sisters.

Hypothesis 3a was rejected. First and second born sons had a lower survival rate to age 5 than their sisters regardless of birth order. While this was an unexpected result from this data, higher male mortality is expected evolutionarily with more males dying in 
infancy than females. Hypothesis $3 b$ was supported. First and second born daughters were more likely to survive to ages 5 and 15 than younger born sons.

It is possible that these results may be in part an artifact of the data. Information was more readily available for sons than daughters, so it is possible that this impacted the data and related results, making us able to detect the effects of birth order on child survival for sons rather than daughters. On the other hand, while there did not appear to be a relationship between gender and birth order for females, there was a clear result that females were surviving more overall than their male siblings, regardless of birth order. This is the expected result in high mortality human societies lacking direct discrimination against daughters, thus it suggests that either male mortality was especially high or that the data recorded are in fact not strongly biased by sex.

Voland and Dunbar (1995) found that among the eighteenth and nineteenth century Krummhōrn farmers, birth order influenced male infant mortality. The more male siblings there were in a family, the higher the infant mortality rate for males. A similar result was also found for females as well. The higher the number of daughters in a family, the higher the infant mortality rate was for younger daughters. Borgerhoff Mulder (1992) and Mace (1996) found that larger inter-birth intervals resulted in higher quality offspring and higher levels of parental investment. Smaller inter-birth intervals resulted in higher numbers (quantity) of offspring, but also resulted in lower levels of parental investment (and higher mortality rates). In this study there was a preference for sons however, daughters had lower mortality rates. For example, 95 percent of first and second born daughters survived to age five in comparison to first and second born sons who had a survival rate of 91 percent. Daughters with a birth order of three and above had a survival 
rate of 91 percent and sons with the same birth order had a survival rate of 87 percent. This was also true on survival to age 15. First and second born daughters had a survival rate of 90 percent compared to 88 percent for first and second born sons. Daughters with a birth order of 3 and up had a survival rate of 89 percent compared to 80 percent of sons with the same birth order.

The amount of resources available to parents may also impact child survival. Hrdy (1999) and Voland (1998) found that across cultures the amount of investment from parents varies based on the availability of resources. Mothers with abundant resources will generally invest more in their offspring leading to lower child mortality rates, while mothers with a lack of resources will generally invest less in each offspring, resulting in higher child mortality rates. These findings supported the Trivers-Willard hypothesis (1973). The findings in this chapter are consistent with the current literature on child survival. Birth order and gender did impact the level of parental investment and associated child survival. Daughters consistently survived better than sons in all birth orders and across all time periods. This result is consistent with the current literature with females traditionally surviving at higher rates than males regardless of birth order. This could have also potentially increased the importance of males in this population.

Hrdy and Voland (1999) argued that mothers with abundant resources would invest more in their offspring and this was consistent with what was found in this study. Women in this sample population would have experienced shorter inter-birth intervals resulting in a higher number of offspring produced overall, but with high infant mortality. 


\section{Parental investment}

Chapter 7 examined the effects of parental investment using outcomes related to wealth and status. Three sets of hypotheses were examined: 4a) Parents will invest most heavily in their first born and second born sons as reflected in more titles and higher titles. 4b) First and second born sons will be less likely to join the church than their younger brothers. Sons with a birth order of three or higher will be more likely to enter the church than their older brothers. 4c) Sons with a birth order of 3 and above will attain high rank in the Church. 5a) First and second born daughters will be less likely to join the Church than their younger sisters. Daughters with birth orders 3 and higher will be more likely to enter the Church. 5b) First and second born daughters will be less likely to hold high titles within the Church then their younger sisters. Daughters with a birth order of 3 or higher were more likely to obtain high church titles than first and second born daughters. 6) First and second born sons will have larger estates than their younger brothers. Sons with a birth order of 3 and up will have smaller estates than their older brothers.

Hypothesis 4a was supported. First and second born sons were more likely to hold titles than their younger brothers. Hypothesis $4 \mathrm{~b}$ was also supported. There was a negative result for first and second born sons indicating that they were less likely to join the church than their younger brothers. There was a positive relationship for sons with a birth order of three and higher and membership in the church. The final hypothesis in this set, 4c, was also supported. Sons with a birth order of three and higher were more likely to attain a high rank in the Church than their older brothers. 
The next set of hypotheses in this chapter related to females joining the church. Both hypotheses were supported. First and second born daughters were less likely to join the Church than their younger sisters while daughters with higher birth orders ( 3 and above) were more likely to join the Church than their older sisters. First and second born daughters were less likely to hold high titles within the Church than their younger sisters with a birth order of three and above.

The final set of analyses in this chapter dealt with birth order and estate size. Hypothesis 6 was supported. First and second born sons were more likely to hold large estates than their younger brothers with a birth order of three and above. All three sets of hypotheses in this chapter were thus supported.

Unlike child survival which can be affected by a variety of factors, and may be difficult to determine based on the limited availability of sources, title transfers are clear. A title was transferred through inheritance or bestowal or it was not. Due to the importance of title transfer and the wealth associated with it, this information was recorded with much more accuracy than birth information. The same is true for Church titles. One either entered the Church or they did not. They were either given a highranking title or they were not. This information would have been recorded by the immediate family, but also by the Church and the convent or monastery the individual joined.

Estate size is also a good measure of parental investment because the land and titles that are transferred/inherited needed to be duly recorded for economic and tax purposes. The crowns of both England and France would have taken particular interest in 
the size of estates, and the manors held, in order to tax their owners accurately. As a result, there were two sets of records, one within the family unit and one royal.

Multiple studies have found that differential parental investment may favor certain offspring over others (Hartung 1982; Dickemann 1979; Rohde et. al 2003;

Hopcroft 2005; Lawson and Mace 2011; Lawson et. al. 2012). Boone (1986, 1988) found in societies with large amounts of heritable wealth and established inheritance patterns, there is a preference for sons over daughters. A similar result was found in Hrdy (1992) and Hrdy and Judge (1993) which indicated that elite parents are more likely to invest resources in sons than in daughters. Boone (1988) also found a similar pattern among the Portuguese nobility with high ranking men investing more resources in their sons and their daughters and low ranking men investing more in their daughters than their sons.

The results from this dissertation are consistent with the literature. Members of the English and French aristocracy invested additional resources in their first and second born sons and daughters over their younger born children, with a clear preference for sons overs daughters. Consistent with what Boone (1998) found, first and second born sons received additional titles, land, and wealth. Younger born sons and daughters received lesser amounts of wealth and/or positions within the church.

\section{Marriage}

Chapter 8 used consanguineous and affinal kin marriages as a measure of parental investment. Two hypotheses were associated with this chapter: hypothesis 7 and hypothesis 8 . Hypothesis 7) Higher born offspring are more likely to marry consanguineous kin than later born offspring. Younger born offspring (those with higher 
birth orders) will be more likely to marry affinal kin. Hypothesis 8) Later born daughters will be more likely to have a spouse who is $5+$ years older than her.

Hypothesis 7 was partially supported and partially rejected. There were no significant results for first and second born sons in relation to consanguineous or affinal marriage. First born and second born daughters did have a significant effect of marrying consanguineous kin, though there was no effect for first or second born daughters marrying affinal kin. Sons with a birth order of three and higher also had no significance in regards to marrying consanguineous or affinal kin. Daughters with a birth order of three or higher were less likely to marry affinal kin than their older sisters.

Hypothesis 8 was also rejected. There were no significant effects or results for later born daughters and the likelihood that their spouses would be 5 or more years older than them.

Cross culturally, incest taboos reduce the level of inbreeding, however, under specific circumstances, such as having large amounts of heritable wealth, endogamous marriages may occur. Levi-Strauss (1969) argued that cross cousin marriages allowed for the maintenance of family ties. Van den Berghe (1980) also found that the desire for alliances between lineages within the same family would overrule the incest taboo. In multiple historic populations, ancient Egypt, the Inca, several African (Swazi, Zulu, and Thembu) and Asian cultures (Thailand, Vietnam, and Cambodia) intermarriage with close kin was common. In medieval Europe, it was also common to marry consanguineous kin, even after the Catholic Church began to place restrictions on marriage partners. Marrying close kin allowed families to maintain and strengthen alliances, thereby securing the wealth of the family. 
The marriage of close kin could be one useful method of maintaining the status of a family. Endogamous marriages limit the transfer of the familial wealth to someone outside the unit. For example, during the sixteenth, seventeenth, and eighteenth centuries, the aristocratic families of Spain, Portugal, Austria, and Russia consistently used endogamous marriage to prevent the transfer of wealth outside the family. Given this pattern, it would also be expected that first and second born children would be more likely to marry consanguineous kin than their younger siblings. At the same time, if kin marriages occurred for those younger siblings, then one would expect those partners to be affinal kin. There were several instances of both types of marriages in the sample population. The effects were varied in our analysis. First born and second born daughters were more likely to marry consanguineous kin. Daughters with a birth order of 3 and up were less likely to marry affinal kin. There was no effect for first or second born sons for either consanguineous or affinal kin marriages.

\section{Reproductive success}

Evolutionarily speaking, males will out-produce females in the total number of offspring. This will continue over successive generations as well with males having more grandchildren, and great-grandchildren than their sisters. This is due in part to biological restrictions, but it can also be the result of differing levels of parental investment. Flinn (1986) found that males in a Caribbean village who had more land and those who lived in the same village as their parents had greater reproductive success than males who lacked these things. These males also had greater reproductive success than their sisters. Turke and Betzig (1985) found that reproductive success among Ifaluk men was tied closely to their status and wealth with men of higher status having higher reproductive success. 
The findings in this chapter were also consistent with Boone (1988) who found that Portuguese men in high ranking lineages had greater reproductive success than their younger brothers. Daughters of lower ranking men were able to marry hypergamously resulting in large numbers of daughters of higher ranking men destined for a life unmarried in the Church.

Chapter 9 examined reproductive success as a measure of parental investment. Two hypotheses were tested in this chapter: Hypothesis 9a) First and second born sons will produce more children, grandchildren, great-grandchildren, and great-great grandchildren than their younger brothers. Hypothesis 9b) First and second born daughters will produce more children, grandchildren, great-grandchildren, and great-great grandchildren than their younger sisters, though this effect will be weaker than the effect in sons.

Reproductive success is one of the strongest tests of parental investment and this was further supported by the results in this chapter. The first part of hypothesis 9a was supported. First and second born sons did produce more children, grandchildren, greatgrandchildren, and great-great grandchildren then their younger brothers, though the effect for first born sons was stronger and endured over more generations than the result for second born sons. This was the expected result. Older male offspring will have additional parental investment in the form of inheritance. This allows them to make more advantageous marriages and potentially increase their overall mating success.

The second part of hypothesis 9a was also supported. Sons with a birth order of three and above produced fewer children, grandchildren, great-grandchildren, and greatgreat grandchildren than their older brothers. This could be the result of reduced parental 
investment, e.g. poorer health, lack of titles, or later age at marriage. It could also be a result of membership in the Church, an alternate form of parental investment that left no legal descendants to compete for inheritance with the descendants of their older brothers.

It should be noted that all progeny included in this study were legitimate. Males can potentially have larger numbers of mates and produce a large number of illegitimate children. However, there are two issues with including illegitimate children in a sample. One, unless the child was recognized by their father, their birth information would be virtually impossible to locate. Second, only legitimate children were eligible to inherit titles and status from their fathers. Therefore, the reproductive success of the males in this sample is limited by legitimacy, making it a conservative estimate. The actual numbers could potentially be even higher than what was recorded.

Hypothesis $9 \mathrm{~b}$ was supported. There was a significant result for first and second born daughters in relation to the number of children born. First and second born daughters produced more children than their younger sisters, while daughters with a birth order of three or higher were shown to have fewer children than their older sisters. The effect for lower fertility among younger sisters is expected given their higher rates of entering the church, an occupation associated with celibacy and thus low fertility. In the third and fourth generation there appeared to be a decline in the fertility for daughters overall. This could be an artifact of the data as it becomes more difficult to collect data as the number of generations increase. There is also the issue of underreporting of offspring. Historically, female infants and infants who died at young ages in general were more likely to not have their birth recorded. This lack of data can skew the results of progeny especially across multiple generations. However, even with this in mind, there were still 
strong effects for first and second born males and their posterity. Another issue to consider is that with each successive generation the problem of underreporting may become exacerbated. For example, if there are more sons than daughters recorded in the first generation, then the number of grandchildren may not be accurate, and the issue will continue across multiple generations. However, as the historic time period increased, so too did the availability and arguably the accuracy of the household records. For example, while a birth may have not been recorded, or a birth date difficult to determine, for an individual born during time period 1 (1000-1066), an individual born in the fourth time period (1216-1300) may be more likely to have had their birth recorded.

Time period may have had an impact on several of the sets of results. In several analyses there appeared to be positive effects of the time period, especially time periods two and three, that were not seen for time period one. There are two possible explanations for this: one, the earliest time period was from 1000-1066. This was a period of great political uncertainty in both England and France. As a result, the availability and complete nature of historic records may be restricted. Two, in the second and third time periods (1066-1154 and 1155-1215 respectively) considerable political changes occurred and stability was restored in both countries. This could have impacted the availably of records with more information being recorded and preserved. This means that the effects in time periods two and three could be an artifact of the data. More children may have been born in time period one than were actually recorded. As a result, the number of children born in time periods two and three may have actually been similar to the number born in time period one, it just does not appear that way once the data are collected. On the other hand, it could also be true that stability in time periods 2 and 3 had a real effect 
on outcomes analyzed in these results, including the likelihood of child survival or the amounts invested per child.

\section{Conclusions}

While there were four hypotheses that were directly rejected and two that were partially rejected, the majority of hypotheses associated with this dissertation were accepted (10 were fully accepted and two were partially accepted). In this sample population, parents did invest differentially in their offspring based on birth order and gender. First and second born sons were of utmost importance given the established inheritance pattern (primogeniture). Sons also experienced higher infant mortality rates than their sisters, so additional parental investment was necessary to ensure the security of the family line.

Child survival and consanguineous and affinal kin marriages had mixed results which could be due in part to the limitations explained above. The inheritance of titles and wealth and reproductive success provided clearer evidence of differential parental investment. Sons did receive more parental investment than their sisters overall. Older sons received additional amounts of investment than younger born sons as evidenced by the inheritance of titles and wealth and their reproductive success. Older daughters also received more parental investment than their younger born sisters as seen by the lack of Church titles among older daughters and the increased number of those titles among younger born daughters. Younger sisters also experienced lower reproductive success, which could also be classified as an effect of reduced parental investment — or at least the result of parental investment decisions to send those daughters to the Church, which 
Deady et al. (2006) have argued could be a strategy to increase family status and influence while reducing potential conflict between heirs.

This dissertation will add to the understanding of differential parental investment using the measures of child survival, marriage, and reproductive success. The results from this study indicate that parents are willing to provide different amounts of investment in their offspring based on birth order and gender.

The research conducted in this dissertation will continue as information is collected on additional medieval families thereby increasing the size of the database. In addition to England and France, there are also historic archival data available on other aristocratic families in Spain, Portugal, Denmark, and the numerous German principalities. With the collection of additional data, more rigorous statistical analysis may be conducted to test the hypotheses outlined here. 
APPENDIX: FAMILY GROUP SHEET

Family Group Sheet

\begin{tabular}{|c|c|c|c|c|c|}
\hline \multicolumn{2}{|c|}{ Name } & & & & \\
\hline \multicolumn{6}{|c|}{ Family Name } \\
\hline \multicolumn{6}{|c|}{ Mother family name } \\
\hline \multicolumn{6}{|c|}{ Marriage name } \\
\hline \multicolumn{6}{|c|}{ Title } \\
\hline \multicolumn{6}{|c|}{ Name of Father } \\
\hline \multicolumn{6}{|c|}{ Name of Mother } \\
\hline Sex & $\begin{array}{l}\text { Birth } \\
\text { Date }\end{array}$ & $\begin{array}{c}\text { Birth } \\
\text { Location }\end{array}$ & \multicolumn{2}{|c|}{ Death Date } & Death Location \\
\hline $\begin{array}{l}\text { Age at } \\
\text { Death }\end{array}$ & $\begin{array}{c}\text { Survive } \\
\text { to Age } \\
5 ?\end{array}$ & $\begin{array}{l}\text { Survive to } \\
\text { Age 15? }\end{array}$ & $\begin{array}{c}\text { Older } \\
\text { brother } \\
\text { died? }\end{array}$ & $\begin{array}{l}\text { Older } \\
\text { sister } \\
\text { died? }\end{array}$ & \\
\hline $\begin{array}{c}\text { Died } \\
\text { before } \\
\text { mother? }\end{array}$ & $\begin{array}{c}\text { Died } \\
\text { after } \\
\text { mother? }\end{array}$ & $\begin{array}{l}\text { Died before } \\
\text { father? }\end{array}$ & $\begin{array}{c}\text { Died } \\
\text { after } \\
\text { father? }\end{array}$ & $\begin{array}{c}\text { Preceded } \\
\text { mother? }\end{array}$ & Preceded father? \\
\hline $\begin{array}{l}\text { Birth } \\
\text { Order } \\
\text { mother }\end{array}$ & $\begin{array}{c}\text { BO } \\
\text { male/ } \\
\text { mother }\end{array}$ & $\begin{array}{l}\text { BO female/ } \\
\text { mother }\end{array}$ & $\begin{array}{l}\text { Birth } \\
\text { Order } \\
\text { father }\end{array}$ & $\begin{array}{l}\text { BO male/ } \\
\text { father }\end{array}$ & BO female/father \\
\hline $\begin{array}{l}\text { First born } \\
(\mathrm{Y} / \mathrm{N})\end{array}$ & $\begin{array}{c}\text { Second } \\
\text { born } \\
(\mathrm{Y} / \mathrm{N})\end{array}$ & $\begin{array}{l}\text { Age/Death } \\
\text { of mother }\end{array}$ & $\begin{array}{l}\text { Age/ } \\
\text { Death of } \\
\text { father }\end{array}$ & & \\
\hline \multicolumn{6}{|c|}{$1^{\text {st }}$ Spouse Name } \\
\hline & & & & & \\
\hline
\end{tabular}




\begin{tabular}{|c|c|c|c|c|c|c|c|}
\hline $\begin{array}{c}\text { Spouse } \\
\text { Birth Date }\end{array}$ & $\begin{array}{c}\text { Spouse } \\
\text { Death } \\
\text { Date }\end{array}$ & $\begin{array}{l}\text { Spouse } \\
\text { Age at } \\
\text { Death }\end{array}$ & $\begin{array}{l}\text { Age @ } \\
\text { death of } \\
\text { mother }\end{array}$ & $\begin{array}{l}\text { Age @ } \\
\text { death of } \\
\text { father }\end{array}$ & \multicolumn{2}{|c|}{$1^{\text {st }}$ born } & $\begin{array}{c}2^{\text {nd }} \\
\text { born }\end{array}$ \\
\hline \multicolumn{8}{|c|}{ Spouse Mother } \\
\hline \multicolumn{8}{|c|}{ Spouse Father } \\
\hline \multicolumn{8}{|c|}{ Family Name } \\
\hline \multicolumn{8}{|c|}{ Mother family name } \\
\hline \multicolumn{4}{|c|}{ Spouse Title } & \multicolumn{2}{|c|}{$\begin{array}{c}\text { Spouse High } \\
\text { Title }\left(1^{\mathrm{st}}\right. \\
\mathrm{Y} / \mathrm{N})\end{array}$} & \multicolumn{2}{|c|}{$\begin{array}{l}\text { Spouse } \\
\text { Highest } \\
\text { title }\end{array}$} \\
\hline $\begin{array}{c}1^{\text {st }} \text { marriage } \\
\text { date }\end{array}$ & $\begin{array}{c}\text { Spouse } \\
\text { age @ } \\
\text { marriage }\end{array}$ & $\begin{array}{l}\text { Age @ } 1^{\text {st }} \\
\text { birth }\end{array}$ & $\begin{array}{l}\text { Spouse age } \\
@ 1^{\text {st }} \text { birth }\end{array}$ & $\begin{array}{c}\# \\
\text { children } \\
\text { born }\end{array}$ & $\begin{array}{l}\# \mathrm{~s} \\
\text { bo }\end{array}$ & & $\begin{array}{l}\text { \# daus } \\
\text { born }\end{array}$ \\
\hline $\begin{array}{l}\# \text { sons } \\
\text { survive }\end{array}$ & $\begin{array}{l}\text { \# daus } \\
\text { survive }\end{array}$ & $\begin{array}{l}\text { \# grand- } \\
\text { children } \\
\text { born }\end{array}$ & $\begin{array}{l}\text { \# grandsons } \\
\text { born }\end{array}$ & $\begin{array}{l}\text { \# grand- } \\
\text { daus } \\
\text { born }\end{array}$ & $\begin{array}{l}\# \text { gr } \\
\text { chil } \\
\text { sur }\end{array}$ & $\begin{array}{l}\text { nd- } \\
\text { ren } \\
\text { ve }\end{array}$ & $\begin{array}{c}\text { \# } \\
\text { grand- } \\
\text { daus } \\
\text { survive }\end{array}$ \\
\hline $\begin{array}{l}\text { \# great- } \\
\text { grand- } \\
\text { children } \\
\text { born }\end{array}$ & $\begin{array}{l}\text { \# great- } \\
\text { grandson } \\
\text { born }\end{array}$ & $\begin{array}{c}\text { \# great- } \\
\text { granddaus } \\
\text { born }\end{array}$ & $\begin{array}{l}\text { \# great- } \\
\text { grand- } \\
\text { children } \\
\text { survive }\end{array}$ & $\begin{array}{l}\text { \# great- } \\
\text { grand- } \\
\text { sons } \\
\text { born }\end{array}$ & $\begin{array}{r}\text { \# gr } \\
\text { gra } \\
\text { da } \\
\text { bo }\end{array}$ & & \\
\hline $\begin{array}{l}\text { \# great-great } \\
\text { grand- } \\
\text { children } \\
\text { born }\end{array}$ & $\begin{array}{l}\text { \# great- } \\
\text { great } \\
\text { grandson } \\
\text { born }\end{array}$ & $\begin{array}{l}\text { \# great- } \\
\text { great } \\
\text { granddaus } \\
\text { born }\end{array}$ & $\begin{array}{l}\text { \# great- great } \\
\text { grand- } \\
\text { children } \\
\text { survive }\end{array}$ & $\begin{array}{l}\text { \# great- } \\
\text { great } \\
\text { grandso } \\
\text { ns born }\end{array}$ & $\begin{array}{c}\text { \# gr } \\
\text { gre } \\
\text { gra } \\
\text { da } \\
\text { bo }\end{array}$ & & \\
\hline
\end{tabular}




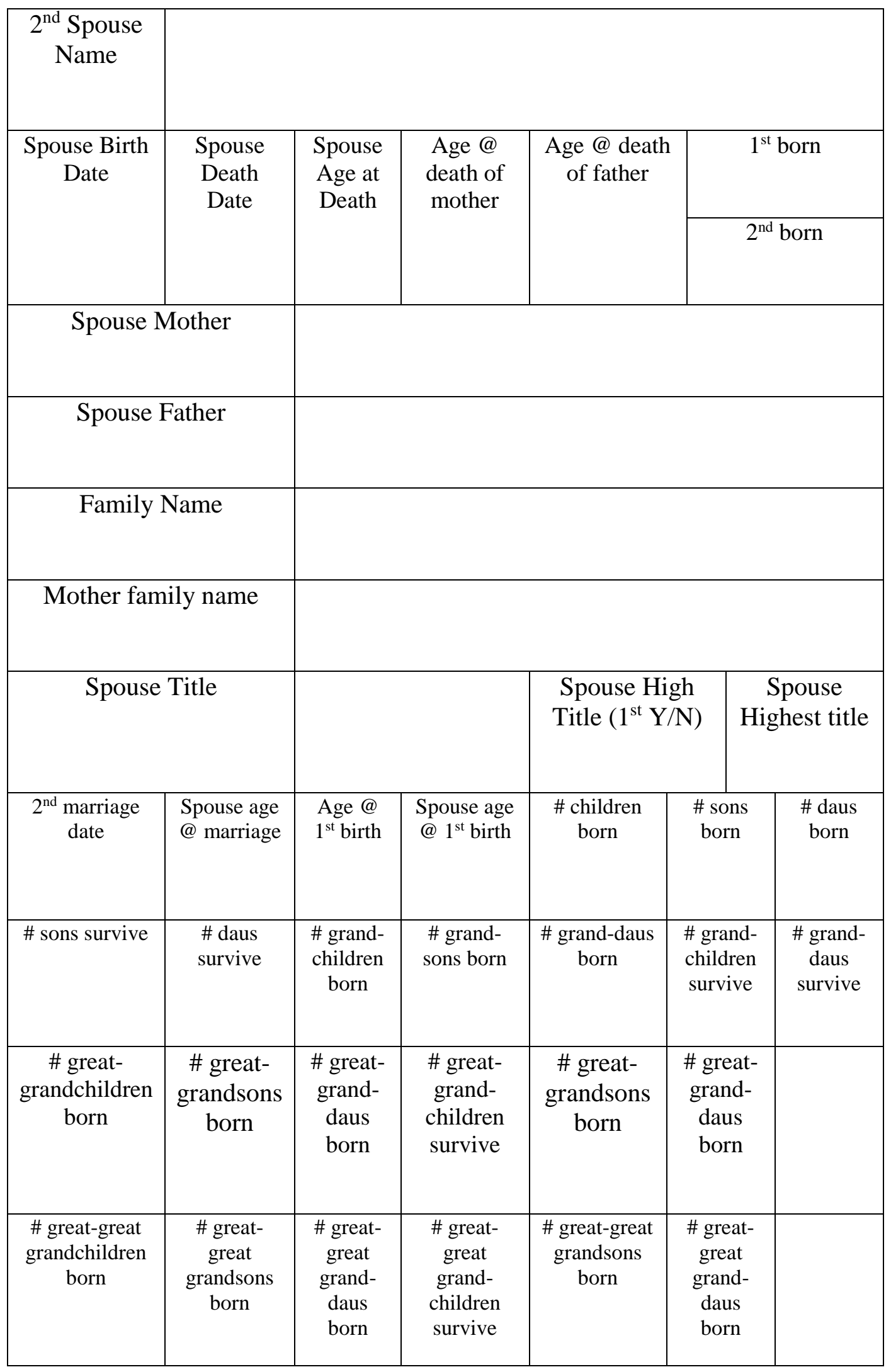




\begin{tabular}{|c|c|c|c|c|c|c|c|}
\hline $\begin{array}{c}3^{\text {rd }} \\
\text { Spouse } \\
\text { Name }\end{array}$ & & & & & & & \\
\hline $\begin{array}{c}\text { Spouse } \\
\text { Birth Date }\end{array}$ & $\begin{array}{l}\text { Spouse } \\
\text { Death } \\
\text { Date }\end{array}$ & $\begin{array}{l}\text { Spouse Age } \\
\text { at Death }\end{array}$ & $\begin{array}{l}\text { Age @ death of } \\
\text { mother }\end{array}$ & $\begin{array}{c}\text { Age @ } \\
\text { death of } \\
\text { father }\end{array}$ & \multicolumn{2}{|c|}{$1^{\text {st }}$ born } & $\begin{array}{l}2^{\text {nd }} \\
\text { born }\end{array}$ \\
\hline \multicolumn{8}{|c|}{ Spouse Mother } \\
\hline \multicolumn{8}{|c|}{ Spouse Father } \\
\hline \multicolumn{8}{|c|}{ Family Name } \\
\hline \multicolumn{8}{|c|}{$\begin{array}{l}\text { Mother family } \\
\text { name }\end{array}$} \\
\hline \multicolumn{4}{|c|}{ Spouse Title } & \multicolumn{2}{|c|}{$\begin{array}{l}\text { Spouse High Title } \\
\left(1^{\text {st }} \mathrm{Y} / \mathrm{N}\right)\end{array}$} & \multicolumn{2}{|c|}{$\begin{array}{c}\text { Spouse } \\
\text { Highest title }\end{array}$} \\
\hline $\begin{array}{c}3^{\text {rd }} \\
\text { marriage } \\
\text { date }\end{array}$ & $\begin{array}{c}\text { Spouse } \\
\text { age @ } \\
\text { marriage }\end{array}$ & $\begin{array}{l}\text { Age @ } 1^{\text {st }} \\
\text { birth }\end{array}$ & $\begin{array}{c}\text { Spouse age @ } \\
1^{\text {st }} \text { birth }\end{array}$ & \multicolumn{2}{|c|}{ \# children born } & \multicolumn{2}{|c|}{ \# sons born } \\
\hline $\begin{array}{l}\text { \# sons } \\
\text { survive }\end{array}$ & $\begin{array}{l}\text { \# daus } \\
\text { survive }\end{array}$ & $\begin{array}{l}\text { \# grand- } \\
\text { children } \\
\text { born }\end{array}$ & $\begin{array}{l}\text { \# grandsons } \\
\text { born }\end{array}$ & $\begin{array}{c}\# \\
\text { granddaus } \\
\text { born }\end{array}$ & \multicolumn{2}{|c|}{$\begin{array}{l}\text { \# grand- } \\
\text { children } \\
\text { survive }\end{array}$} & $\begin{array}{c}\text { \# } \\
\text { grand- } \\
\text { daus } \\
\text { survive }\end{array}$ \\
\hline $\begin{array}{l}\text { great- } \\
\text { grandchil } \\
\text { dren born }\end{array}$ & $\begin{array}{l} \\
\text { great- } \\
\text { grandso } \\
\text { ns born }\end{array}$ & $\begin{array}{c}\text { great- } \\
\text { granddaus } \\
\text { born }\end{array}$ & $\begin{array}{c}\text { great- }^{-} \\
\text {grandchildren } \\
\text { survive }\end{array}$ & $\begin{array}{c}\text { \# } \\
\text { great- } \\
\text { grandson } \\
\text { s born }\end{array}$ & $\begin{array}{r}\text { gre } \\
\text { grand } \\
\text { bo }\end{array}$ & $\begin{array}{l}\text { \# } \\
\text { t- } \\
\text { aus }\end{array}$ & \\
\hline
\end{tabular}




\begin{tabular}{|c|c|c|c|c|c|c|}
\hline $\begin{array}{c}\text { \# great- } \\
\text { great } \\
\text { grand- } \\
\text { children } \\
\text { born }\end{array}$ & $\begin{array}{c}\text { \# great- } \\
\text { great } \\
\text { grandsons } \\
\text { born }\end{array}$ & $\begin{array}{c}\text { \# great- } \\
\text { great grand- } \\
\text { daus born }\end{array}$ & $\begin{array}{c}\text { \# great- great } \\
\text { grandchildren } \\
\text { survive }\end{array}$ & $\begin{array}{c}\text { \# great- } \\
\text { great } \\
\text { grandsons } \\
\text { born }\end{array}$ & $\begin{array}{c}\text { \# great- } \\
\text { great } \\
\text { granddaus } \\
\text { born }\end{array}$ & \\
& & & & & & \\
& & & & & & \\
\hline
\end{tabular}

\begin{tabular}{|c|c|c|c|c|c|c|c|}
\hline $\begin{array}{c}\text { 4th } \\
\text { Spouse } \\
\text { Name }\end{array}$ & & & & & & & \\
\hline $\begin{array}{c}\text { Spouse } \\
\text { Birth Date }\end{array}$ & $\begin{array}{c}\text { Spouse } \\
\text { Death } \\
\text { Date }\end{array}$ & $\begin{array}{l}\text { Spouse Age } \\
\text { at Death }\end{array}$ & $\begin{array}{l}\text { Age @ death of } \\
\text { mother }\end{array}$ & $\begin{array}{c}\text { Age @ } \\
\text { death of } \\
\text { father }\end{array}$ & \multicolumn{2}{|c|}{$1^{\text {st }}$ born } & $\begin{array}{l}2^{\text {nd }} \\
\text { born }\end{array}$ \\
\hline \multicolumn{8}{|c|}{ Spouse Mother } \\
\hline \multicolumn{8}{|c|}{ Spouse Father } \\
\hline \multicolumn{8}{|c|}{ Family Name } \\
\hline \multicolumn{8}{|c|}{$\begin{array}{l}\text { Mother family } \\
\text { name }\end{array}$} \\
\hline \multicolumn{4}{|c|}{ Spouse Title } & \multicolumn{2}{|c|}{$\begin{array}{c}\text { Spouse High Title } \\
\left(1^{\text {st }} \mathrm{Y} / \mathrm{N}\right)\end{array}$} & \multicolumn{2}{|c|}{$\begin{array}{c}\text { Spouse } \\
\text { Highest title }\end{array}$} \\
\hline \multirow[t]{2}{*}{$\begin{array}{c}\text { 4th } \\
\text { marriage } \\
\text { date }\end{array}$} & $\begin{array}{c}\text { Spouse } \\
\text { age @ } \\
\text { marriage }\end{array}$ & $\begin{array}{l}\text { Age @ } 1^{\text {st }} \\
\text { birth }\end{array}$ & $\begin{array}{c}\text { Spouse age @ } \\
1^{\text {st }} \text { birth }\end{array}$ & \multicolumn{2}{|c|}{ \# children born } & \multicolumn{2}{|c|}{ \# sons born } \\
\hline & & & & & & \multicolumn{2}{|c|}{ \# daus born } \\
\hline $\begin{array}{l}\text { \# sons } \\
\text { survive }\end{array}$ & $\begin{array}{l}\text { \# daus } \\
\text { survive }\end{array}$ & $\begin{array}{l}\text { \# grand- } \\
\text { children } \\
\text { born }\end{array}$ & $\begin{array}{l}\text { \# grandsons } \\
\text { born }\end{array}$ & $\begin{array}{c}\# \\
\text { granddaus } \\
\text { born }\end{array}$ & $\begin{array}{l}\# \text { gi } \\
\text { chil } \\
\text { sur }\end{array}$ & & $\begin{array}{c}\text { \# } \\
\text { grand- } \\
\text { daus } \\
\text { survive }\end{array}$ \\
\hline
\end{tabular}




\begin{tabular}{|c|c|c|c|c|c|c|}
\hline $\begin{array}{l}\text { \# great- } \\
\text { grandchild } \\
\text { ren born }\end{array}$ & $\begin{array}{l}\text { \# great- } \\
\text { grandsons } \\
\text { born }\end{array}$ & $\begin{array}{l}\text { \# great- } \\
\text { granddaus } \\
\text { born }\end{array}$ & $\begin{array}{c}\text { \# great- } \\
\text { grandchildren } \\
\text { survive }\end{array}$ & $\begin{array}{l}\text { \# great- } \\
\text { grandsons } \\
\text { born }\end{array}$ & $\begin{array}{l}\text { \# great- } \\
\text { granddaus } \\
\text { born }\end{array}$ & \\
\hline $\begin{array}{l}\text { \# great- } \\
\text { great } \\
\text { grand- } \\
\text { children } \\
\text { born }\end{array}$ & $\begin{array}{l}\text { \# great- } \\
\text { great } \\
\text { grandsons } \\
\text { born }\end{array}$ & $\begin{array}{l}\text { \# great- } \\
\text { great grand- } \\
\text { daus born }\end{array}$ & $\begin{array}{l}\text { \# great- great } \\
\text { grandchildren } \\
\text { survive }\end{array}$ & $\begin{array}{l}\text { \# great- } \\
\text { great } \\
\text { grandsons } \\
\text { born }\end{array}$ & $\begin{array}{c}\text { \# great- } \\
\text { great } \\
\text { granddaus } \\
\text { born }\end{array}$ & \\
\hline $\begin{array}{l}\text { Title } \\
(\mathrm{Y} / \mathrm{N})\end{array}$ & \# of Titles & $\begin{array}{l}\text { How title } \\
\text { acquired }\end{array}$ & \multicolumn{4}{|c|}{ Actual Title name } \\
\hline $\begin{array}{l}\text { Enter } \\
\text { Church } \\
(\mathrm{Y} / \mathrm{N})\end{array}$ & $\begin{array}{l}\text { Attained } \\
\text { high rank } \\
\text { (Y/N) }\end{array}$ & $\begin{array}{l}\text { Actual Rank } \\
(1-9)\end{array}$ & \multicolumn{2}{|c|}{ Occupation $(0,1,2)$} & Cause of D & ath \\
\hline $\begin{array}{l}\text { Church } \\
\text { Burial } \\
(\mathrm{Y} / \mathrm{N})\end{array}$ & \multicolumn{6}{|c|}{ Burial Location } \\
\hline $\begin{array}{l}\text { Estate } \\
\text { Size } \\
(0,1,2)\end{array}$ & \multicolumn{3}{|c|}{ Related to Spouse (Y/N) } & \multicolumn{3}{|c|}{ Affinal/Consanguineal (1/2) } \\
\hline
\end{tabular}




\section{References}

Adler, N.E., Boyce, T, M.A. Chesney, S. Cohen, S. Folkman, R. Kahn, and Syme, S. (1994) Socioeconomic Status and Health: the Challenge of the Gradient. American Psychologist 49:15-24.

Ager, S.L. (2005) Familiarity breeds: incest and the Ptolemaic dynasty. Journal Hellenic Studies. 125:1-34.

Anderson, V. (1993) The De Veres of Castle Hedingham. Suffolk: Terence Dalton.

Apostolou, M. (2007). Sexual Selection Under Parental Choice: The Role of Parents in the Evolution of Human Mating. Evolution and Human Behavior 28(6): 403-409.

Aristotle. On the Generation of Animals. N.p., 2013. Web. 09 Dec. 2013. <http://ebooks.adelaide.edu.au/a/aristotle/generation/book4.html>.

The Articella $\left(13^{\text {th }}-16^{\text {th }}\right.$ centuries $)$ Collection of authors. Accessed online.

Bailey, DH., KR., Hill, and R. Walker (2014) Fitness consequences of spousal relatedness in 46 small-scale societies. Biology Letters 10:20140160.

Ball H and C. Hill (1996) Twin Infanticide. Current Anthropology 37:5 856-863.

Barlow F. (2013) The Godwins" The Rise and Fall of a Noble Dynasty. New York: Taylor and Francis Publishing.

Barney, S. A., W. J. Lewis, Beach, J. A., and O. Berghof, eds. (2006) The Etymologies of Isidore of Seville. Cambridge: Cambridge University Press.

Bartlett, R. (2000) England under the Norman and Angevian Kings: 1075-1225. Oxford: Clarendon Press.

Barton, N. and A. Etheridge (2011) The relation between reproductive value and genetic contribution. Genetics 188:953-973. 
Bateman, A.J. (1948) Intra-sexual selection in Drosophila. Heredity 2 (Pt. 3): 349-368.

Beaumont E. (1928) The Beaumonts in History: A.D. 850-1850. Oxford.

Becker, G.S. and Lewis H.G. (1973) On the interaction between quantity and quality of children. Journal Political Economy 81:S279-S288.

Bell, D. (1997) Defining Marriage and Legitimacy. Current Anthropology 38:237-254.

Bennett, J.M. (2006) Medieval Europe: A Short History. McGraw Hill.

Betzig, L. and S. Weber. (1995) Presidents Preferred Sons. Politics and the Life Sciences. 14: 61-64.

Betzig, L. (1995) Medieval Monogamy. Journal of Family History 2:181-216.

Bitel, L. (2002) Women in early medieval Europe: 400-1100. Cambridge: Cambridge University Press.

Bittles A.H. and M.L. Black (2010) Consanguinity, human evolution and complex diseases. Proceedings National Academic Sciences. 107:1779-1786.

Bittles, A.H. and H.A. Hamamy (2010) Consanguinity and endogamy in Arab Countries. In Genetic Disorders Among Arab Populations. A. Teebi and S. Ahmad (eds.). Oxford University Press.

Blakely, R. (2005) Robert de Brus I: Founder of the Family. The Brus family in England and Scotland, 1100-1295. Woodbridge: Boyell Press.

Bluhm, C. K. and P. A. Gowaty (2004) Reproductive compensation for offspring viability deficits by female mallards, Anas platyrhynchos. Animal Behavior 68:985-992.

Blurton-Jones, N. (1986) Bushman birth spaceing: A test for optimal interbirth intervals. Ethology and Sociobiology 7 (2):91-105. 
Blurton-Jones, N. (1987) Bushman birth spacing: direct tsts of some simple predictions. Ethology and Sociobiology 8(3): 183-203.

Boone, J. L. (1986) Parental Investment and Elite Family Structure in Preindustrial States: A Case Study of Late Medieval-Early Modern Portuguese Genealogies. American Anthropologist New Series 88:859-878.

Boone, J. L. (1988) Parental Investment, Social Subordination, and Population Processes Among the $15^{\text {th }}$ and $16^{\text {th }}$ Century Portuguese Nobility. In Human Reproductive Behavior: A Darwinian perspective, L. Betzig, M. Borgerhoff Mulder, and P. Turke (eds). Cambridge: University Press, pp. 201-219.

Borgerhoff -Mulder, M. (1992) Reproductive Decisions, In Smith EA. Winterhalder B (eds) Evolutionary Ecology and Human Behaviour. Aldine de Gruyter, New York.

Borgerhoff -Mulder, M. (1998) Brothers and Sisters: How Sibling Interactions Affect Optimal Parental Allocations. Human Nature 9:119-162.

Borgerhoff-Mulder, M. (2000) Optimizing offspring: the quantity-quality tradeoff in agropastoral Kipsigis. Evolution and Human Behavior 21 (6): 391-410.

Borgerhoff -Mulder, M. (2007) Hamilton's Rule and Kin Competition: The Kipsigis Case. Evolution and Human Behavior 28:299-312.

Borgerhoff-Mulder, M. (2011) Optimizing offspring: the quantity-quality tradeoff in agropastoral Kipsigis. Evolutionary Human Behavior 21:391-140.

Borgerhoff-Mulder, M. and R. Schacht (2012) Human behavioural ecology. In: Encyclopedia of life sciences. Chichester (UK). 
Bouchard, C. (1981) Consanguinity, and Noble Marriages in the Tenth and Eleventh Centuries. Speculum 56:268-287.

Brooke, C. (1981) Marriage and Society in the Central Middle Ages. In Marriage and Society: Studies in the Social History of Marriage, R.B. Oathwaite (ed.).

Brundage, J.A. (1987). Law, Sex, and Christian Society in Medieval Europe. Chicago: University of Chicago Press.

Burley, N. (1986) Sexual selection for aesthetic traits in species with biparental care. American Naturalist 127:415-445.

Buss, D., and D. Schmitt (1993) Sexual Strategies Theory: An evolutionary perspective. Psychological Review 100(2): 204-232.

Cantor, N. (1994) The Civilization of the Middle Ages. New York: Harper Perennial.

Chagnon, N., Lynch, R., Shenk, M.K. (2017). Cross-cousins marriage among the Yanomamo shows evidence of parent-offspring conflict and mate competition between brothers. Proceedings of the National Academy of Sciences. 114:25902598.

Chisholm, J.S. (1993) Death, Hope, and Sex - Life History and the Development of Reproductive Strategies. Current Anthropology 34:1-24.

Clarke A.L., and Low, B.S. (2001) Testing Evolutionary Hypotheses with Demographic Data. Population and Development Review 27:633-660.

Coall, D.A., Hilbrand, S., and Hertwig, R. (2014) Predictors of Grandparental Investment Decisions in Contemporary Europe: Biological Relatedness and Beyond. PloS ONE 9(1):1-10. 
Cooper, J. F. (1978) Patterns of Inheritance and Settlement by Great Landowners from the Fifteenth to the Eighteenth Centuries. In Family and Inheritance: Rural Society in Western Europe 1200-1800. J. Goody, J. Thirsk, and E.O. Thompson, (Eds.) Cambridge: Cambridge University Press.

Cronk, L. (1991) Preferential Parental Investment in Daughters Over Sons. Human Nature 2:387-417.

Crouch, D. (1986) The Beaumont Twins: The Roots and Branches of Power in the Twelfth Century. Cambridge.

Crouch, D. (2015) The Acts and Letter of the Marshal Family: Marshals of England and Earls of Pembroke, 1145-1248. Camden Society $5^{\text {th }}$ Series 47. Cambridge University Press for the Royal Historical Society.

Crouch, D. (2016) William Marshal: Knighthood, War and Chivalry, 1147-1219. London: Routldge.

Daly, M. Wilson, M. (1982). Homicide and Kinship. American Anthropologist 84:372378.

Davidson, A. B., and R. B. Ekelund, (1997). The medieval church and rents from marriage market regulations. Journal of Economic Behavior and Organization $32: 215-245$.

Deady, D., M. Smith, J.P. Kent, and Dunbar, R.I.M. (2005) Is Priesthood an Adaptive Strategy? Evidence from a Historical Irish Population. Human Nature. 17:393404. 
Derry, T. K. (1979). A History of Scandinavia: Norway, Sweden, Denmark, Finland, and Iceland. Minneapolis: University of Minnesota Press.

Dickemann, M. (1979). Female Infanticide, Reproductive Strategies, and Social Stratification: A Preliminary Model. Pp. 321-367 in Evolutionary Biology and Human Social Behavior: An Anthropological perspective, edited by Napoleon Chagnon and William Irons. North Scituate, MA: Duxbury Press.

Diggelmann, L., (2004) Marriage, Inheritance, and the Balance of Power in TwelfthCentury England and France. University of Auckland, dissertation.

Diggelmann, L., (2016) Marriage, Peace, and Enmity in the Twelfth Century. Common Knowledge 22:237-255.

Dosdon, A., (2010). The Complete Royal Families of Ancient Egypt. London: Thames and Hudson.

Donahue, C. (1983). The Canon Laws on the Formation of Marriage and Social Practice in the Latter Middle Ages. Journal of Family History 8:144-158.

Downey, D. (2000) Number of Siblings and intellectual development: the resource dilution explanation. American Psychologist 56:497-504.

Draper, P. and R. Hames. (2000) Birth Order, Sibling Investment, and Fertility among Ju/'hoansi (!Kung). Human Nature 11:117-156.

Duby, G. (1977) The Chivalrous Society. Berkeley: University of California Press. Duby, G., (1978) Medieval Marriage: Two Models from Twelfth-Century France, translated by Elborg Forster. Baltimore: Johns Hopkins University Press.

Durham, W. (1991) Coevolution: Genes, Culture, and Human Diversity. Stanford University Press. 
Ember, M., (1975). On the Origin and Extension of the Incest Taboo. Behavior Science Research. 10(4): 249-281.

Evans-Grubbs, J. (2007) Marriage and Its Documentation in Later Roman Law. Pp. 43-94 in To have and to hold: Marrying and its documentation in Western Christendom: 400-1600, edited by Philip L. Reynolds and John Witte Jr. Cambridge University Press.

Fieder, M. and Huber, S. (2007). The effects of sex and childlesness on the association between status and reproductive output in modern society. Evolution and Human Behavior 28:392-398.

Fields, J.D. (2005) The Ties that bind: kinship networks and the colonial development of the planter elite in Westmoreland County, Virginia. Master's Thesis, Indiana State University.

Fildes, V. (1986) Breasts, Bottles, and Babies: A History of Infant Feeding. Edinburgh University Press.

Fink.org.uk

Fischer, D.H. (1989). Albion's Seed: Four British Folkways in America. New York: Oxford University Press.

Fisher, R.A. (1958) The Genetical Theory of Natural Selection. Oxford University Press. Flandrin, J. (1976) Families in former times: kinship, household, and sexuality. Cambridge: Cambridge University Press.

Fleming, P. (1973) The Politics of Marriage Among Non-Catholic European Royalty. Current Anthropology 14: 231-249. 
Fox, R. (1983) Kinship and marriage: an anthropological perspective. Cambridge studies in social anthropology. Cambridge University Press.

Fox-Genovese, E. (1988) Within the Plantation Household: Black and White Women of the Old South, series on Gender and American Culture, Chapel Hill, NC: University of North Carolina Press.

Fratkin, E. (1991) Surviving drought and development: Ariaal pastoralists of northern Kenya. Westview Press, Boulder.

Gabler, S. Voland, E. (1994) Fitness of Twinning Human Biology Vol. 66:4 699-713.

Gaulin, S.J.C., Boster J.S. (1990) Dowry as Female Competition. American Anthropologist 92: 994-1005.

Geary, D.C. (2005) Evolution of paternal investment. In D.M. Buss (Ed.), The Evolutionary psychology handbook. 493-505. Hoboken, NJ: John Wiley and Sons.

Gibson, M.A. and Lawson D.W. (2011) Modernization increases parental investment and sibling resource competition evidence from a rural development initiative in Ethiopia. Evolution and Human Behavior 32: 97-105.

Gibson, M.A. and Mace, R. (2006) An energy-saving development initiative increases birth rate and childhood malnutrition in rural Ethiopia. PloS Medicine. 3(4):1-9.

Gillespie, D. Russell A. Lummaa V., (2008) When fecundity does not equal fitness: evidence of an offspring quality trade-off in pre-industrial humans. Proceedings Royal Society B 275:713-722.

Giuffra, V., and Fornaciari, G., (2012) Breastfeeding and Weaning in Renaissance Italy: The Medici Children. Breastfeeding Medicine 8:1-6. 
Goodman, A. Koupil I., and Lawson, D.W., (2012) Low fertility increases descendant socioeconomic position but reduces long-term fitness in a modern post-industrial society. Proceedings Royal Society B 279:4342-4351.

Goody, J. (1983) The development of the family and marriage in Europe. Cambridge: Cambridge University Press.

Gowaty, P. A. (2008) Reproductive compensation. Journal of Evolutionary Biology 21, $1189-1200$.

Gowaty, P. A., Anderson, W. W., Bluhm, C. K., Drickamer, L. C., Kim, Y. K. \& Moore, A. J. (2007) The hypothesis of reproductive compensation and its assumptions about mate preferences and offspring viability. Proc. Natl. Acad. Sci. 38:1502315027.

Giudice, M., Gangestad, S., and Kaplan, H., (2015) Life History Theory and Evolutionary Psychology. In The Handbook of Evolutionary Psychology, Buss, D.M. (ed.). John Wiley and Sons.

Hager, B.J. (1992) Get Thee to a Nunnery: Female Religious Claustration in Medieval Europe. Ethology and Sociobiology 13:382-407.

Hager, R. and R.A. Johnstone (2003) The genetic basis of family conflict resolution in mice. Nature 421:533-535.

Hajnal, J. (1965) European Marriage Patterns in Perspective. In Population in History, D.V. Glass and D. Eversley (eds.). London: Edward Arnold.

Hames, R. (1988) The Allocation of Parental Care among the Ye'kwana. In Human Reproductive Behaviour, L. Betzig, M. Borgerhoff Mulder, and P. Turke, eds. Pp. 237-254. Cambridge: Cambridge University Press. 
Hames, R. and McCabe, C. (2007) Meal sharing among the Ye'kwana. Human Nature 18:1-21.

Hamilton, W.D. (1964) The Genetical Evolution of Social Behaviour Journal of Theoretical Biology 7:1-16.

Harpending, H. and Rogers, A.R. (1990) Fitness in stratified societies. Ethology and Sociobiology 11:497-509.

Harris, E. and Uller, T. (2009) Reproductive investment differential allocation versus reproductive compensation. Philosophical Transactions of the Royal Society B. 364: 1039-1048.

Harris, M. (1977) Cannibals and Kings: The Origins of Cultures. New York: Vintage.

Hartung, J. (1976) On Natural Selection and the Inheritance of Wealth. Current Anthropology 17:607-622.

Hartung, J. (1982) Polygyny and the Inheritance of Wealth. Current Anthropology 23:112.

Hawkes, K., O’Connell, J. F., Blurton Jones, N. G., Alvarez, H., and Charnov, E. L. (1998) Grandmothering, menopause and the evolution of human life histories. Proceedings of the National Academy of Sciences 95:1336-1339.

Helle, S. V. Lummaa, and Jokela, J. (2004) Selection for Increased Brood Size in Historical Human Populations. Evolution 58: 430-436.

Helmholz, R. H. (1974) Marriage Litigation in Medieval England. London: Cambridge University Press. 
Helmholz, R. H. (2007) Marriage Contracts In Medieval England Pp. 260-286 in To have and to hold: Marrying and its documentation in Western Christendom: 400-1600, edited by Philip L. Reynolds and John Witte Jr. Cambridge University Press.

Herlihy, D. (1985) Medieval Households. Cambridge: Harvard University Press.

Hewlett, B. (1988) Sexual Selection and Paternal Investment among Aka Pygmies. In Human Reproductive Behaviour: A Darwinian Perspective, Laura Betzig, Monique Borgerhoff Mulder, and Paul Turke (eds.) Cambridge: Cambridge University Press.

Hewlett, B.S. (1991) Demography and childcare in preindustrial societies. Journal of Anthropological Research 47:1-37.

Hewlett, B.S. (2008) Fathers and infants among Aka pygmies. In Anthropology and child development: A cross-cultural reader. R.A. Levine, R.S. Now (eds.). pg. 84-99. Blackwell Publishers Ltd., Malden.

Hewlett, B. and S. Winn (2014) Allomaternal nursing in humans. Current Anthropology 55: $200-229$.

Hill, K. (1993) Life History Theory and Evolutionary Anthropology. Evolutionary Anthropology 2: 78-88.

Hill, K. and M. Hurtado (1996) Ache Life History: The Ecology and Demography of Foraging People. Transaction Publishers, New York.

Hill, K., H. Kaplan (1999) Life History Traits in Humans: Theory and Empirical Studies. Annual Review of Anthropology 28:397-430.

Hobcraft, J. McDonald J., and Rutstein S. (1983) Childspacing effects on infant and early child mortality. Popul. Index 49:585-618. 
Hollingsworth, T.H. (1957) A Demographic Study of the British Ducal Families. Population Studies 11: 4-26.

Hollingsworth, T.H. (1964) The Demography of the British Peerage. Population Studies 18, Supplement No. 2.

Hopcroft, R. L. (2005) Parental Status and Differential Investment in Sons and Daughters: Trivers-Willard Revisited. Social Forces 83:1111-1136.

Houston, A. I. \& McNamara, J. M. (1999). Models of adaptive behaviour: an approach based on state. Cambridge, UK: Cambridge University Press.

Hrdy, S. B. (1992) Fitness Tradeoffs in the History and Evolution of Delegated mothering, with Special Reference to Wet-Nursing, Abandonment, and Infanticide. IN, Laura Betzig (ed). Darwinian History. Special issue of Ethology and Sociobiology 13: 409-442.

Hrdy, S. B. and D. Judge. (1993) Darwin and the Puzzle of Primogeniture. Human Nature 4:1-45.

Hughes, D.O. (1978) From Brideprice to Dowry in Mediterranean Europe. Journal of Family History 3:262-296.

Hurtado, A. M., K. Hawkes, K. Hill, and H. Kaplan (1985) Female Subsistence Strategies among Ache Hunter-gatherers of Eastern Paraguay. Human Ecology 13:1-28

Ingoldsby, B. B. (2006) Mate Selection and Marriage. IN, Bron Ingoldsby and Suzanna Smith (eds). London: Sage Publications. 
Johnson, S. B. and R. C. Johnson (1991) Support and Conflict of Kinsmen in Norse Earldoms, Icelandic families, and the English Royalty. Ethology and Sociobiology 12: $211-220$.

Johow, J., Fox, M., Knapp, L., Voland, E. (2011) The presence of a paternal grandmother lengthens interbirth interval following the birth of a granddaughter in Krummhorn (18 ${ }^{\text {th }}$ and $19^{\text {th }}$ centuries). Evolution and Human Behavior. 32:315-325.

Kaplan, H. (1996) A Theory of Fertility and Parental investment in Traditional and Modern Human Societies Yearbook of Physical Anthropology 39:91-135.

Kaplan, H., S. Gangestad (2004) Life History Theory and Evolutionary Psychology, DRAFT.

Kaplan, H., and K. Hill (1985) Food Sharing among Ache Foragers: Tests of Explanatory Hypotheses. Current Anthropology 26:223-245.

Kaplan, H. Lancaster, J. and Bock, J. (1995) Does observed fertility maximize fitness among New Mexican men? A test of an optimality model and a new theory of parental investment in the embodied capital of offspring. Human Nature 6:325360.

Kaplan, H., Hill, K., Lancaster, J., \& Hurtado, A. M. (2000). A theory of human life history evolution, diet, intelligence, and longevity. Evolutionary Anthropology $9: 156-185$.

Kaplan, H. and S. Gangestad (2005) Life history theory and evolutionary psychology. In D. M. Buss (Ed.), The handbook of evolutionary psychology (pp. 68-95). New York: Wiley. 
Kilday, A. (2013) A History of Infanticide in Britain, c. 1600 to the Present. Basingstoke: Palgrave Macmillan.

Kokkonen A. and Sundell, A. (2014) Delivering Stability-Primogeniture and Autocratic Survival in European Monarchies 1000-1800. American Political Science Review 108:2, 438-153.

Kroll, J. and B. S. Bachrach. (1990) Medieval Dynastic Decisions: Evolutionary Biology and Historical Explanation. Journal of Interdisciplinary History 21:1-28.

Laslett, P. (1969) Size and Structure of the Household in England Over Three Centuries. Population Studies 23: 199-234.

Lawson, D. Alvergne A. Gibson, M (2012) The life-history trade-off between fertility and child survival. Philosophical Transactions of the Royal Society of London B 279:4755-4764.

Lawson, D. and Mace, R. (2011) Parental investment and the optimization of human family size. Phil. Trans. R. Society B 336:333-343.

Lawson, D. and Borgerhoff Mulder, M. (2016) The offspring quantity-quality trade-off and human fertility variation. Philosophical Transactions of the Royal Society of London B 371:1-11.

Lee, R. (1979) The !Kung San Men, Women, and Work in a Foraging Society. Cambridge: Cambridge University Press.

Levi-Strauss, C. (1969) The Elementary Structures of Kinship. Beacon Press.

Leyser, H. (1995) Medieval Women: A Social History of Women in England: 450-1500. New York: St. Martin's Press. 
Livingston, A. (1997) Kith and Kin: Kinship and Family Structure of the Nobility of Eleventh-and Twelfth-Century Blois-Chartres. French Historical Studies 20:419458.

Livingston, A. (2010) Out of love for my kin: Aristocratic family life in the lands of the Loire, 1000-1200. Ithaca: Cornell University Press.

Low, B. S. (1991) Reproductive life in nineteenth century Sweden: an evolutionary perspective on demographic phenomena. Ethology and Sociobiology 12:411-448.

Low, B.S (1998) The evolution of human life histories. In Crawford C, Krebs DL (eds) Handbook of Evolutionary Psychology: Ideas, Issues, and Applications. Lawrence Eribaum Associates, Mahwah NJ.

Lucas, A. (1983) Women in the Middle Ages: Religion, Marriage, and Letters. New York: St. Martin's Press.

Lyon, J. (2013) Princely brothers and sisters: the sibling bond in German politics, 11001250. Cornell University Press.

Mace, R (1996) Biased Parental Investment and Reproductive Success in Gabbra Pastoralists: Behavioral Ecology and Sociobiology 38:2. 75-81.

Mace, R (1998) The coevolution of human fertility and wealth inheritance strategies. Phil. Trans. Soc. Lond. B 353:389-397

Mace, R. (1999) Evolutionary Ecology of Human Life History. Animal Behaviour 59: 110.

Mace, R. (2000) Evolutionary ecology of human life history. Animal Behaviour 59:1-10. Mace, R. and R. Sear (2008) Who keeps children alive? A review of the effects of kin on child survival. Evolution and Human Behavior 29 (1):1-18. 
Malinowski, B. (1927). Sex and repression in savage society. London: Allen and Unwin. Map of medieval England.

familysearch.org/wiki/en/Domesday_Book/media/Field:Domesday_Book__Count ies_of_England_-_1086.png

Marlowe, F. (2000) Paternal investment and the human mating system. Behavioural Processes, 51:45-61.

Marlowe, F. (2001). Male Contribution to Diet and Female Reproductive Success among Foragers. Current Anthropology 42: 755-759.

Martindale, J. (1977) The French Aristocracy in the Early Middle Ages: A Reappraisal. Past and Present 75:5-45.

Mason E. (2004) The House of Godwin: The History of a Dynasty. Cambridge University Press.

Mason, J.F.A. (1963) Roger de Montgomery and His Sons (1067-1102). Transactions of the Royal Historical Society, $5^{\text {th }}$ Series Vol 13: 24.

Masters, S. (1994). Consanguinitas Et Ius Sanguinis: Kinship Calculation and Medieval Marriage. Master's Theses Western Michigan University.

McCarthy, C. ed. (2004) Love, Sex, and Marriage in the Middle Ages: A Sourcebook. London: Routledge.

McCarthy, C. (2004) Marriage in Medieval England: Law, Literature, and Practice. Woodbridge: The Boydell Press.

McClaren, D. (1979). Nature's Contraceptive, Wet-Nursing and Prolonged Lactation: The Case of Chesham, Buckinghamshire, 1578-1601. Medical History 23:426441. 
McCullough, J.M., and Barton, E.Y., (1991) Relatedness and mortality risk during a crisis year: Plymouth colony, 1620-1621. Ethology and Sociobiology 12(3): 195209.

McCullough, J.M., Heath, K.M. and Fields, J.D. (2006) Culling the Cousins: Kingship, Kinship, and Competition in Mid-Millennial England. J. History of the Family 11:73-80.

McDougall, S. (2013) The Making of Marriage in Medieval France. Journal of Family History 38:103-121.

Meij J., Bodegom D., Ziem J., Amankwa, J., Polderman A., Kirkwood, T., Craen A., Zwaan B., and Westerndorp R. (2009) Quality-quantity trade-off of human offspring under adverse environmental conditions. Journal of Evolutionary Biology 22:1014-1023.

Miller, L.C. and Fishkin, S.A. (2014). On the Dynamics of Human Bonding and Reproductive Success: Seeking Windows on the Adapted-for HumanEnvironmental Interface. In Evolutionary Social Psychology. J. Simpson, D. Kenrick eds.New York: Taylor and Francis Group.

Moeller, AP and Thornhill, R., (1998) Bilateral symmetry and sexual selection - a metaanalysis. American Naturalist 151:174-192.

Morris, M. (2008) The Bigod Earls of Norfolk in the Thirteenth Century. Boydell Press. Murdock, G. (1949). Social structure. Macmillian.

Murray, J. (2001) Love, Marriage, and Family in the Middle Ages: A Reader. Broadview Press Ltd. 
Neyer, F.J., and Lang, F.R. (2003) Blood is thicker than water: Kinship orientation across adulthood. Journal of Personality and Social Psychology 84(2): 310-321.

Ober, C., Hyslop, T., Hauck, W. (1999) Inbreeding effects on fertility in humans: evidence for reproductive compensation. American Journal of Human Genetics 64:225-231.

Orme, N. (2003) Medieval Children. Yale University Press.

Ottenheimer, M (1996) U.S. laws prohibiting the marriage of relatives, In Forbidden Relatives: The American Myth of Cousin Marriage. Urbana: University of Illinois Press.

Painter, S. (1955) The Houses of Lusignan and Chatellerault 1150-1250. Speculum 30 (3): 374-384.

Parkin, R. and Stone, L. (2004) Kinship and Family: An Anthropological Reader. Oxford: Blackwell Publishing

Pasternak, B., (1976) Introduction to Kinship and Social Organization. Bloomington: Prentice-Hall.

Paul, D.B. and Spencer H.G. (2008) "Its ok, we're not cousin by blood": the cousin marriage controversy in historical perspective. PLoS Biol. 6:e320.

Pennington, R., and H. Harpending (1988) Fitness and fertility among Kalahari !Kung. American Journal of Physical Anthropology 77:303-319.

Pennington, R., H., Harpending (1993) The Structure of an African Pastoralist Community: Demography, History, and Ecology of the Ngamiland Herero. Clarendon Press. 
Quinlan, R. (2007) Human parental effort and environmental risk. Proceedings of Biological Science 274:121-125.

Qvarnström, A. and Price, T., (2001) Maternal effects, paternal effects, and sexual selection. Trends in Ecology and Evolution 16:95-100.

Radulescu, R. and Kennedy, E. eds. (2008) Broken Lines: Genealogical Literature in Medieval Britain and France. Belgium: Brepols Publishers.

Rallason, D. (2003) Northumbria, 500-1100: Creation and Destruction of a Kingdom, Cambridge University Press.

Regalski, J.M. and Gaulin, S.J.C. (1993) Whom are Mexican infants said to resemble? Monitoring and fostering paternal confidence in the Yutacan. Ethology and Sociobiology 14:97-113.

Reynolds, P. and Witte, J. eds. (2007) To have and to hold: Marrying and its documentation in western Christendom, 400-1600. Cambridge: Cambridge University Press.

Ribordy, G. (2001) The Two Paths to Marriage: the Preliminaries of Noble Marriage in Late Medieval France. Journal of Family History 26:323-336.

Robertson, A. J. (ed. And trans.) (1925) The Laws of the Kings of England from Edmund to Henry I. Cambridge: Cambridge University Press.

Rohde, P., Atzwanger, K., Butovskaya, M., Lampert, A., Mysterud, I., Sanzhez-Andres, A., Sulloway, F., (2003) Preceived parental favoritism, closeness to kin, and the rebel of the family: The effects of birth order and sex. Evolution and Human Behavior 24:261-276. 
Rosenthal, J. T. (1984) Aristocratic Marriage and the English Peerage, 1350-1500: Social Institution and Personal Bond. Journal of Medieval History 10: 181-194.

Rubin, L. (2018) America, Aristotle, and the Politics of a Middle Class. Waco: Baylor University Press.

Rutman, D.B. and Rutman, A.H. A Place in Time: Middlesex County, Virginia 16501750. New York: W.W. Norton and Company.

Salmon, C.A., (1999) On the Impact of Sex and Birth Order on Contact with Kin. Human Nature. 10:183-197.

Salmon, C.A., and Daly, M. (1998) Birth Order and Family Sentiment: Middleborns are Different. Evolution and Human Behavior 19: 299-312.

Sanders, I.J. (1960) English Baronies: A Study of their Origin and Descent 1086-1327, Oxford University Press.

Scheidel W. (1996) Brother-sister and parent-child marriage outside royal families in Ancient Egypt and Iran: a challenge to the sociological view of incest. Ethnology and Sociobiology. 17:319-40.

Scheidel W. (1997) Brother-sister marriage in Roman Egypt. J. Biosoc Sci 29:361-71.

Scheidel W. (2004) Ancient Egyptian sibling marriage and the Westermarck effect. In Inbreeding, incest, and the Incest Taboo, ed. AP Wolf, WH Durham (eds.) Stanford, CA: Stanford University Press.

Schneider, D., (2004) What is kinship all about? In Parkin, R. and Stone, L. (2004) Kinship and Family: An Anthropological Reader. Oxford: Blackwell Publishing. Schulz, J.F., Bahrami-Rad, D., Beauchamp, J.P. and J. Heinrich (2019) The Church, intensive kinship, and global psychological variation. Science 366:1-12. 
Sear, R. R. Mace, and I. McGregor (2003) The effects of kin on female fertility in rural Gambia. Evolution and Human Behavior 24:25-42.

Sear R., and Mace, R. (2008) Who keeps children alive? A review of the effects of kin on child survival. Evolution and Human Behavior 29(1):1-18.

Shackleford T.K. (2007) Family Relationships: An Evolutionary Perspective. Oxford University Press.

Shahar, S. (1990) Childhood in the Middle Ages. trans. Chaya Galai London: Routledge.

Sheldon, B. C. (2000) Differential allocation: tests, mechanisms and implications. Trends Ecological Evolution 15:397-401

Shenk, M.K. (2013) Evolutionary Approaches to Parental Decisions: How Much to Invest in Your Offspring. IN Essential Building Blocks of Human Nature chapter in press.

Shenk, M.K. and Scelza, B.A. (2012). Parental investment and status-related child outcomes: Timing of father's death affects offspring success. Journal of Biosocial Science, 44(5): 549-569.

Shenk et al. (2016) Consanguineous Marriage, Kinship Ecology, and Market Transition. Current Anthropology 57:137-180.

Shenk, M.K., Kaplan, H., Hooper, P. (2016) Status competition, inequality, and fertility: implications for the demographic transition. Philosophical Transactions of the Royal Society B. 371.

Silk, J.B., (1983) Local Resource Competition and Facultative Adjustment of Sex Ratios in Relation to Competitive Abilities. The American Nationalist 121:56-66. 
Smith, M. S., Kish, B., and Crawford, C. (1987) Inheritance of Wealth as Human Kin Investment. Ethology and Sociobiology 8:171-182.

Stanard, W. (1979) Some Emigrants to Virginia. New York: Clearfield.

Stone, L. (1977) Family, Sex, and Marriage in England, 1500-1800. London: Wiedenfield and Nicholson.

Strassman, B. Gillespie B. (2002) Life-history theory, fertility and reproductive success in humans. Proc. R. Soc. B 269:553-562.

Sussman, G. (1982). Selling mother's milk: The wet-nursing business in France, 17151914. Urbana: University of Illinois Press.

Talmon, Y., (1964) Family and Community in the Kibbutz. Harvard University Press.

Tanner, H. (1992) The Expansion of the Power and Influence of the Counts of Boulogne under Eustace II. Anglo-Norman Studies 14:251-277.

Taylor, C. (2001) The Salic Law and the Valois succession to the French Crown. French History 15:358-377.

Thomas, D. (1972) The Social Origins of Marriage Partners of the British Peerage in the Eighteenth and Nineteenth Centuries. Population Studies 26: 99-111.

Thompson, K. (1996) The Lords of L'Aigle: Ambition and Insecurity on the borders of Normandy. Anglo-Norman Studies XVIII: 177-199.

Thompson, K. (2002) Power and Border Lordship in Medieval France: the County of Perche, 1000-1226. Royal Historical Society.

Thornhill, N., (1991) An evolutionary analysis of rules regulating human inbreeding and marriage. Behavioral and Brain Sciences 14:247-293. 
Ting, J. Wu, J. He, Q., Xu, J. Mace, R. and Tao, Y. (2013) Reproductive competition between females in the matrilineal Mosuo of southwestern China. Philosophical Transactions of the Royal Soceity B. 368:1-11.

Traill, V. J. (2013) The social and political netwroks of the Anglo-Norman aristocracy: the Clare, Giffard and Tosny Kin-groups, c. 940 to c. 1200. University of Glasgow PhD. Dissertation.

Trivers, R. (1972) Parental Investment and Sexual Selection. In Sexual Selection and the Descent Of Man, 1871-1971. D Campbell, (ed.) Chicago: Aldine.

Trivers, R. and D. E. Willard (1973) Natural Selection of Parental Ability to Vary the Sex Ratio of Offspring. Science 179:90-92.

Turke, P. and L. Betzig. (1985) Those Who Can Do: Wealth, Status, and Reproductive Success on Ifaluk. Ethology and Sociobiology 6:79-87.

Turner, J. and Maryanski, A. (2005). Incest: Origins of the Taboo. New York: Paradign Publishers.

Tylesday, J., (2009) Hatshepsut: The Female Pharaoh. London: Viking.

Van den Berghe, P. and G. Mesher (1980) Royal Incest and Inclusive Fitness. American Ethnologist 7: 300-317.

Van den Berghe, P., (1983) Human inbreeding avoidance: Culture in nature. Behavioral and Brain Sciences. 6:91-102.

Verner, J. and Willson, M. F. (1966) The influence of habitats on mating systems of North American passerine birds. Ecology 47:143-147. Voland, E. (1998) Evolutionary Ecology of Human Reproduction. Annual Review of Anthropology 27:347-374. 
Voland, E., E. Siegelkow, and C. Engel. (1991) Cost/Benefit Oriented Parental Investment by High Status Families: The Krummhorn Case. Ethology and Sociobiology 12:105-118.

Voland, E., and Beise, J., (2002) Opposite effects of maternal and paternal grandmothers on infant survival in historical Krummhörn Behavioral Ecology Sociobiology $52: 435-443$.

Voland, E., and Dunbar, R.I.M. (1995) Resource competition and reproduction: The relationship between economic and parental strategies in the Krunnhorn population (1720-1874). Human Nature 6:33-49.

Volk, A., and Atkinson, J., (2013) Infant and child death in the human environment of evolutionary adaptation. Evolution and Human Beahvior 34:182-192.

Wachter, K.W., Hammel, E. A. and P. Laslett. (1978) Population and Social Structure: Advances in Historical Demography. Statistical Studies of Historical Social Structure. Academic Press, New York.

Walker, R. Gurven, M. Burger, O. Hamilton, M. (2008) The trade-off between number and size of offspring in humans and other primates. Proceedings of the Royal Society B 275:827-834.

Walker, R.S., Flinn, M.V., and Hill, K.R. (2010) Evolutionary history of partible paternity in lowland South America. PNAS vol. 107 45:19195-19200.

Walker, R.S., and D.H. Bailey (2014) Marrying Kin in Small-Scale Societies. American Journal of Human Biology 28:384-388.

Wareham, A. (1994) The motives and politics of the Bigod family c. 1066-1177. AngloNorman Studies, 17:223-42. 
Waugh, S. L. (1985) Marriage, Class, and Royal Lordship in England under Henry III. Viator 16:181-208.

Weekes-Shackelford, V., and Shackelford, T. K., (2004) Methods of Filicide: Stepparents and Genetic Parents Kill Differently. Violence and Victims 19:75-81.

Wertheimer, L. (2006) Children of Disorder: Clerical Parentage, Illegitimacy, and Reform in the Middle Ages. Journal of the History of Sexuality, Vol. 15, No. $3: 382-407$.

Westermarck, E. (2003) History of Human Marriage. Volumes 1-3. Kessinger Publishing.

White, G. (1940) The First House of Belleme. Transactions of the Royal Historical Society. 22:84.

Whiteman, S., McHale, S., Soli, A., (2011) Theoretical Perspectives on Sibling Relationships. Journal Family Theory Review 3(2): 14-139.

Williams, G. C. (1966) Adaptation and Natural Selection: A Critique of Some Current Evolutionary Thought. Princeton: Princeton University Press.

Wilson, M.I., Daly, M., and Weghorst, S.J. (1980) Household composition and the risk of child abuse and neglect. Journal of Biosocial Science 12:333-340.

Winking, J., (2006) Are men really that bad as fathers? The role of men's investments. Paper presented at IUSSP Seminar. http://www.unm.edu/ jwinking/FertilityModel.pdf.

Wolf, A. (1970) Childhood Association and Sexual Attraction: A Further Test of the Westermarck Hypothesis. American Anthropologist. 72:503-515. 
VITA

Jessica D. Fields researches historic populations in Europe, specifically England and France, but also has an interest in Spain, Scandinavia, Russia, and Germany. Her research interests include parental investment, birth order and gender, kinship networks, marriage and marriage alliances, genetic relatedness, genealogy, and demography in historic populations. Jessica has presented her research at the Human Behavior and Evolution Society meetings, the Mid-America Medieval Association, and the Midwest Medieval History Conference. She has published in the Journal History of the Family and Encyclopedia of Evolutionary Psychological Science.

Jessica will continue her research amongst historic European populations while teaching at Indiana State University. Jessica D. Fields can be contacted at Jessica.Fields@indstate.edu. 